PATRÍCIA HERMONT BARCELLOS GONÇALVES MADEIRA

\title{
NÃO-CUMULATIVIDADE DO PIS E DA COFINS
}

\author{
DISSERTAÇÃO DE MESTRADO EM DIREITO
}

ORIENTADOR:

PROFESSOR DOUTOR ALCIDES JORGE COSTA

FACULDADE DE DIREITO DA UNIVERSIDADE DE SÃO PAULO SÃO PAULO - 2009 
PATRÍCIA HERMONT BARCELLOS GONÇALVES MADEIRA

\section{NÃO-CUMULATIVIDADE DO PIS E DA COFINS}

Dissertação apresentada à banca examinadora da Faculdade de Direito da Universidade de São Paulo para obtenção do título de Mestre em Direito, sob a orientação do Professoro Doutor Alcides Jorge Costa.

FACULDADE DE DIREITO DA UNIVERSIDADE DE SÃO PAULO

SÃO PAULO - 2009 
Banca Examinadora 
Ao BREno $e$ aos meus PAIS. 


\section{Agradecimentos}

Há um ditado popular segundo o qual não se pode considerar a vida completa antes que se tenha plantado uma árvore, tido um filho e escrito um livro.

Árvores, já plantei algumas.

Os filhos e o livro vieram juntos: a pequena e amada Olívia nasceu em março de 2008, logo após a entrega do texto de qualificação e, em dezembro do mesmo ano, às vésperas do depósito da dissertação, recebemos com alegria a notícia de que em breve ela ganhará um irmão ou irmã.

Não considero que minha vida esteja completa (algum dia estará?). Mas concluir a presente dissertação em meio a tantas mudanças, incluindo a de país, foi um grande passo. E só foi possível graças à ajuda de Deus, da família, dos amigos e colegas.

Por isso, ainda que sob o risco de esquecer alguém, deixo meus sinceros agradecimentos ao meu marido e melhor amigo, BRENO LAGE MADEIRA, com todo o meu amor; aos meus pais, LUIZ ROBERTO e MARIA DO CARMO BARCELLOS GONÇALVES, pelo exemplo; aos meus irmãos, PRISCILA e BERNARDO HERMONT BARCELLOS GONÇALVES, pelo apoio de sempre; aos meus avós, HÉLIO e MARIA EMÍlIA HERMONT, sempre corujas; ao Professor Doutor ALCIDES JORGE COSTA, orientador presente, cujas observações instigantes estimulam o raciocínio jurídico e o crescimento acadêmico e pessoal dos alunos; ao meu sócio, mentor e amigo, EVADREN ANTÔNIO FLAIBAM; ao amigo IGOR MAULER SANTIAGO, pela troca de ideias que muito influenciou a estrutura do texto; ao meu sócio, amigo e primo, RODRIGO ARANTES BARCELLOS CORRÊA, pelas dicas durante todo o curso de mestrado; à ANA CÂNDIDA PICCINO SGAVIOLI, então estagiária, hoje, colega e amiga, pelo auxílio nas pesquisas; ao ALÉCIO LIMA, pela imprescindível ajuda tecnológica com a remessa de artigos via internet; e a todos que cuidaram da OLÍVIA para que eu pudesse me dedicar à escrita: os avós LUIZ ROBERTO e MARIA DO CARMO BARCELlOS GONÇALVES e MÁRCIO e TEREZINHA MADEIRA, os tios MARcos ANTÔNIO e ANDREIA MADEIRA; os primos NATÁlia HERMONT Faleiros, Gustavo Calumby Hermont, Christian W. MOREno Madeira e Bruna MADEIRA Diniz ALVES; e a babá SUELEN AMARAL ALVES. 


\section{SUMÁRIO}

INTRODUÇÃO...

1. A CIRCULAÇÃO DE RIQUEZA COMO FONTE TRIBUTÁVEL ……................. 5

1.1 Fontes de riqueza tributáveis e pressupostos de fato dos impostos................... 5

1.2 Classificação dos impostos no CTN: agrupamento conforme as fontes de riqueza tributáveis

1.2.1 O grupo de impostos sobre a produção e a circulação

2. A FONTE DE RIQUEZA TRIBUTADA PELO PIS E PELA COFINS NÃOCUMULATIVOS

2.1 As materialidades econômicas das contribuições sociais de seguridade social......

2.1.1 Proposta de classificação das contribuições sociais de seguridade social de acordo com os grupos de impostos do CTN.....

2.2.1 Síntese da evolução legislativa e jurisprudencial do PIS e da Cofins ..

2.2.2 Faturamento vs. receita vs. operações: materialidade econômica do PIS e da Cofins não-cumulativos

2.2.3 PIS e Cofins cumulativos vs. PIS e Cofins não-cumulativos ...

2.2.4 PIS e Cofins não-cumulativos: contribuições de seguridade social que tributam a circulação de riquezas.

2.2.4.1 PIS e Cofins não-cumulativos: contribuições de seguridade social sobre a produção e a circulação....

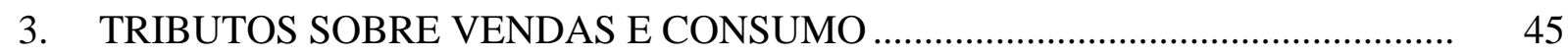

3.1 Preâmbulo

3.1.1 A translação econômica e a translação jurídica

3.1.2 Translação jurídica vs. não-cumulatividade vs. tributação sobre o consumo

3.1.3 Equiparação entre tributos sobre vendas e tributos sobre consumo .....

3.2 Breve histórico da tributação sobre vendas/consumo.

3.2.1 Os inconvenientes da tributação sobre vendas/consumo em cascata (regime plurifásico cumulativo)

3.2.2 Os tributos sobre vendas/consumo na Europa

3.2.2.1 Na França: do Imposto Geral sobre Vendas (L’Impôt sur le Chiffre d'Affaires) ao Imposto sobre o Valor Agregado (La Taxe sur la Valeur Ajoutée)

3.2.2.2 Na União Europeia: da tributação plurifásica em cascata ao Imposto sobre o Valor Acrescido (IVA). 
3.2.3 Tributos sobre vendas/consumo no Brasil

3.2.3.1 Do Imposto sobre Consumo ao Imposto sobre Produtos Industrializados (IPI)

3.2.3.2 o Imposto sobre Vendas e Consignações (IVC) ao Imposto sobre Operações relativas à Circulação de Mercadorias (ICMS) e sobre Prestações de Serviços de Transporte Interestadual e Intermunicipal e de Comunicação

3.3 Formas de arrecadação dos tributos sobre vendas/consumo alternativas à tributação em cascata.

3.3.1 Regimes monofásicos: sobre a produção, sobre o atacado, sobre o varejo

3.3.2 Regime plurifásico não-cumulativo.

3.3.2.1 Formação da base tributável: tipo consumo, tipo renda e tipo produto bruto 75

3.3.2.2 Forma de cálculo do tributo: base pura ou financeira

3.3.2.3 Métodos de cálculo: aditivo, subtrativo e variantes do último (base contra base e tributo contra tributo)

3.3.2.3.1 Desdobramentos do método subtrativo: créditos físicos e créditos financeiros

3.3.2.3.2 Consequências da adoção das variantes dos métodos de cálculo subtrativo: isenções e alíquotas zero, efeitos de recuperação e mecanismos de regulação

3.4 A não-cumulatividade dos tributos brasileiros sobre vendas/consumo na $\mathrm{CF} / 88$

3.4.1 IPI e ICMS: base financeira, método subtrativo, variante imposto contra e imposto

3.4.2 ICMS e IPI: distinção quanto aos efeitos de recuperação e mecanismos de regulação (ou regra de reversão)....

3.4.3 IPI e ICMS: crédito físico vs. crédito financeiro

3.5 Não-cumulatividade: princípio ou regra?

3.5.1 Princípios vs. regras.

3.5.2 Não-cumulatividade do IPI e do ICMS: o princípio e a regra

3.5.2.1 Os princípios relacionados à não-cumulatividade dos tributos brasileiros sobre vendas/consumo

3.5.2.1.1 Não-cumulatividade e capacidade contributiva.....

3.5.2.1.2 Não-cumulatividade e neutralidade

3.5.2.1.2.1 Não-cumulatividade e país de destino

4.2 PIS e Cofins não-cumulativos e a translação jurídica do encargo tributário.... 
4.3 Inexistência de significado único de não-cumulatividade no texto constitucional....................................................................................... 110

4.3.1 Significados possíveis da não-cumulatividade do PIS e da Cofins ...... 114

4.4 Princípios relacionados à não-cumulatividade do PIS e da Cofins ................. 116

4.5 Não-cumulatividade do PIS e da Cofins teria status constitucional?............... 117

4.6 Fatores de discrímen: os setores de atividade econômica ............................... 119

4.7 Os créditos e os insumos ........................................................................ 124

4.5.2 Créditos na isenção e na alíquota zero................................................. 131

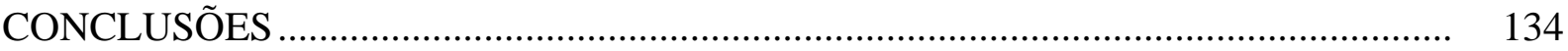

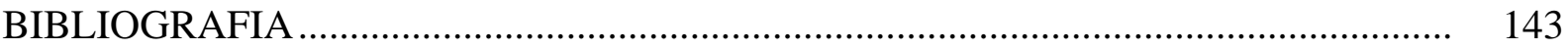

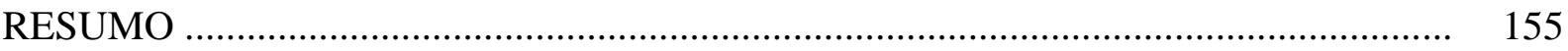

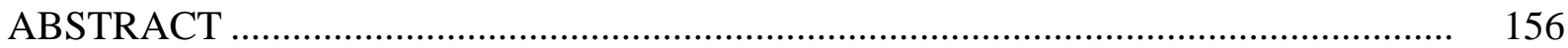




\section{ABREVIATURAS}

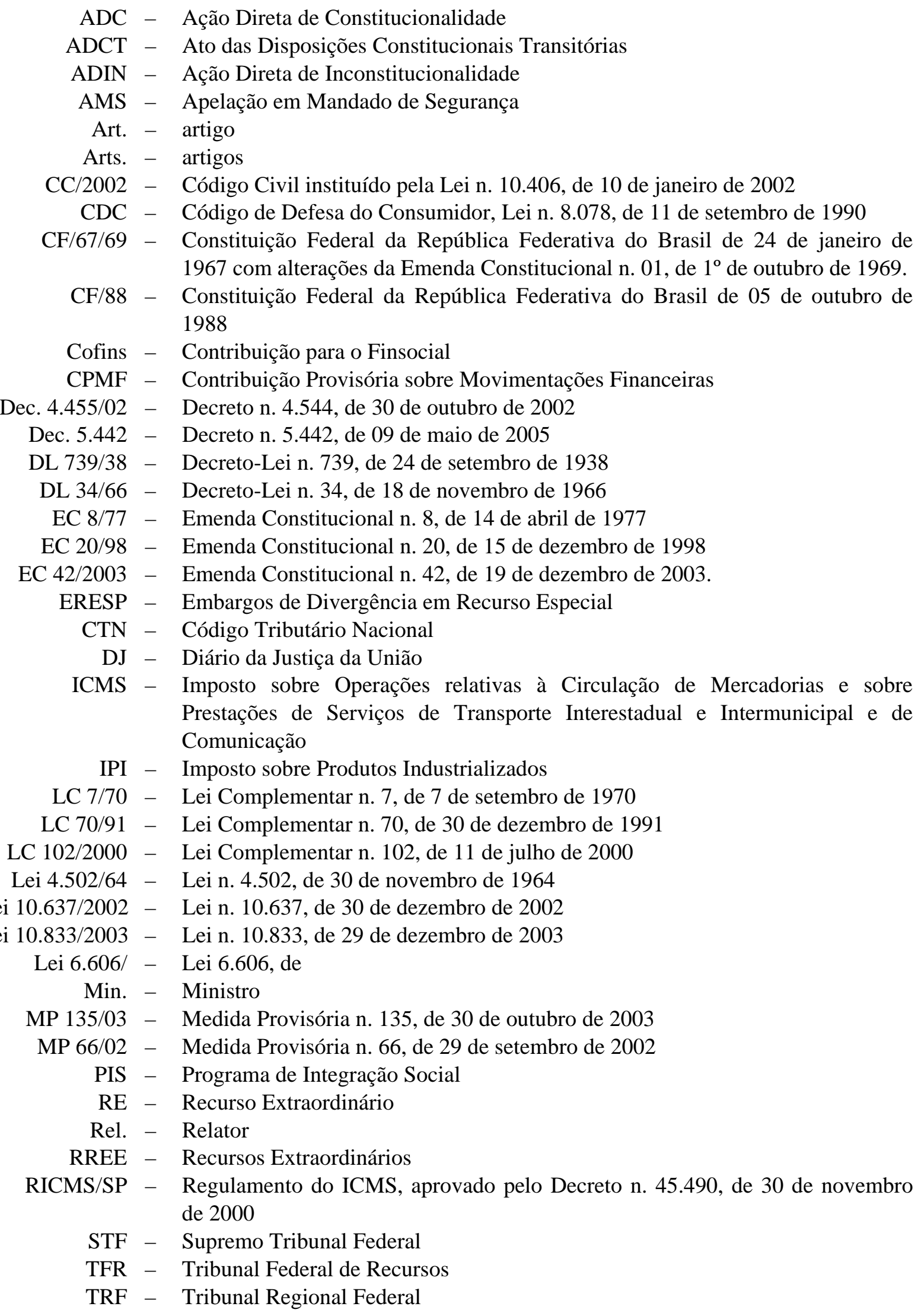




\section{INTRODUÇÃO*}

O PIS e a Cofins são provavelmente as figuras tributárias que, nos últimos anos, mais têm suscitado o interesse da União Federal, dos empresários e, consequentemente, da comunidade jurídica do País.

O interesse da União Federal é compreensível: sobre traduzirem imenso potencial arrecadatório (eis que calculadas sobre o faturamento, equiparado por lei à totalidade da receita das empresas ${ }^{1}$ ), os valores recolhidos não precisam ser repartidos com os Estados nem com os Municípios. Essa exclusividade na gestão do montante arrecadado revela-se de grande importância, dado o "modelo" de federalismo existente no País, ${ }^{2}$ em que a União perde grande parcela de suas receitas para os demais entes federados por força das transferências governamentais mandatórias (v.g., art. 159 da CF), imprescindíveis para a autonomia de alguns Estados e da quase totalidade dos Municípios. ${ }^{3}$

Também não é desarrazoada a preocupação do empresariado, que se depara com imposição das mais agressivas, eis que incidente sobre a totalidade das receitas das pessoas jurídicas.

Sensível a essa gama de interesses, a doutrina tem se debruçado sobre o tema, tecendo críticas que vão desde os malefícios que incidências tributárias sobre o faturamento e

Foram adotadas nesta dissertação as novas regras ortográficas vigentes desde o dia 1. ${ }^{\circ}$.01.2009.

1 Lei 10.637/2002 e Lei 10.833/2003: “Art. 1. ${ }^{\circ}$ A contribuição para o PIS/Pasep (Contribuição para o Financiamento da Seguridade Social - Cofins, na dicção da Lei 10.833/2003) tem como fato gerador o faturamento mensal, assim entendido o total das receitas auferidas pela pessoa jurídica, independentemente de sua denominação ou classificação contábil. § $1 .^{\circ}$ Para efeito do disposto neste artigo, o total das receitas compreende a receita bruta da venda de bens e serviços nas operações em conta própria ou alheia e todas as demais receitas auferidas pela pessoa jurídica”.

2 Luis Eduardo Schoueri, em prefácio à obra $O$ federalismo fiscal brasileiro e o Sistema Tributário Nacional de André Elali (ELALI, André. São Paulo: MP, 2005), reportando-se à investigação do Professor Alcides Jorge Costa, afirma que o "O Brasil é uma Federação em busca de um modelo."

3 DI PIETRO, Juliano. Repartição das receitas tributárias. In: CONTI, José Maurício (Org.). Federalismo fiscal. Barueri: Manoele, 2004. Após analisar os dados da arrecadação de 2001, o autor assevera que "os Municípios [...] são totalmente hipossuficientes no que diz respeito à sua arrecadação própria, [...] o que é compensado com sua participação constitucionalmente definida no produto geral da arrecadação” (p. 85). 
a receita representam para a economia, ${ }^{4}$ até a precariedade da legislação que dispôs sucessivamente sobre as diversas técnicas de arrecadação dessas contribuições: regime plurifásico cumulativo, substituição tributária progressiva, regime monofásico e, mais recentemente, regime plurifásico não-cumulativo. ${ }^{5}$

É dessa última forma de cobrança (multifásica não-cumulativa), instituída pelas Leis 10.637/2002 e 10.833/2003, que se ocupará a presente dissertação.

Tendo em vista que o objeto do presente estudo é a legislação editada após a alteração no art. 195, I, b, promovida pela EC 20/98, ${ }^{6}$ não pretendemos investigar a distinção entre os conceitos receita e faturamento. Partimos da realidade posta: o texto constitucional emendado autorizou a tributação de ambos.

Tampouco pretendemos analisar os efeitos econômicos que a tributação produz sobre o nível de preços, sobre as curvas de oferta e de demanda, enfim, sobre a economia em geral. Tal análise cabe à ciência econômica - não à ciência jurídica - e a autora careceria de conhecimentos para arriscar-se em tal empreitada. Quando nos referirmos a aspectos econômicos, visamos ressaltar a interpenetração entre a realidade econômica e a jurídica, alinhando-nos à lição de Ricardo Lobo Torres, segundo a qual

4 TÔRRES, Heleno Taveira. Monofasia e não-cumulatividade das contribuições ao PIS e à Cofins no setor de petróleo (refinarias). In: PAULSEN, Leandro (Coord.) et al. Não-cumulatividade do PIS/Pasep e da Cofins. São Paulo: IOB Thompson; Porto Alegre: Instituto de Estudos Tributários, 2004. O autor, referindo-se a estudo de 2001, em que o BNDES afirma que "o Brasil é um dos poucos países do mundo que (ainda) cobram tributos incidentes sobre o faturamento e a movimentação financeira geral das empresas produtivas", registra sua "absoluta discordância com qualquer espécie de tributação sobre faturamento, em vista das repercussões que isso representa sobre a produção e crescimento da economia” (p. 25, nota 1).

5 FERREIRA, Júlio de Castilhos. A não-cumulatividade do PIS/Pasep e da Cofins. In: PAULSEN, Leandro (Coord.) et al. Não-cumulatividade do PIS/Pasep e da Cofins. São Paulo: IOB Thompson; Porto Alegre: Instituto de Estudos Tributários, 2004. Segundo o autor, “o tema 'não-cumulatividade do PIS/Pasep e da Cofins' está normatizado, basicamente, pelas Leis 10.637/2002 (PIS/Pasep), 10.833/2003 (Cofins) e 10.685/2004 (PIS/Pasep e Cofins-Importação) [...] diante do quadro com que nos deparamos, que nos lembra o mestre Alfredo Augusto Becker e o seu Manicômio Tributário [...] manifestamos [...] nossa irresignação pela forma apressada, para não dizer coisa pior, como um assunto de tamanha relevância tributária foi tratado pelos legisladores, que trouxeram à luz estes monstrengos que cuidam da nãocumulatividade do PIS/Pasep e da Cofins” (p. 69).

6 “Art. 195. A seguridade social será financiada por toda a sociedade, de forma direta e indireta, nos termos da lei, mediante recursos provenientes dos orçamentos da União, dos Estados, do Distrito Federal e dos Municípios, e das seguintes contribuições sociais: I - do empregador, da empresa e da entidade a ela equiparada na forma da lei, incidentes sobre: $[\ldots]$ b) a receita ou o faturamento.” 
a construção jurídica do sistema tributário nacional tem que se fazer sob a perspectiva do seu relacionamento com os principais problemas estudados pela Economia, como sejam o pleno emprego, a redistribuição de rendas, a fixação dos preços, a conservação dos recursos nacionais, a saúde das empresas, o controle do inflação etc. ${ }^{7}$

Na esteira da linha de pesquisa à qual o presente trabalho se vincula ("Legislação Tributária e Desenvolvimento”) e forte na premissa de que a não-cumulatividade tributária é um dos fatores que contribui para o desenvolvimento do País, o objetivo desta pesquisa é analisar a não-cumulatividade do PIS e da Cofins instituída pelas Leis 10.637/2002 e 10.833/2003 (e alterações posteriores), verificando os pontos que a aproximam e os que a distanciam da não-cumulatividade do ICMS e do IPI, na tentativa de contribuir para a interpretação da complexa legislação que disciplinou aquelas contribuições.

Para evitar os vícios da análise pela negativa, antes de tratar da não-cumulatividade, abordamos a cumulatividade tributária.

Tendo em vista que a não-cumulatividade surgiu no âmbito de tributos sobre a circulação de riquezas, dedicamos algumas páginas do trabalho a entender essa fonte tributável. Este o objeto do Capítulo 1.

Em seguida, analisamos as fontes de riqueza alcançadas pelas contribuições ao PIS e Cofins, suas materialidades econômicas e os pressupostos de fato dos tradicionais impostos brasileiros arrecadados mediante técnica não-cumulativa: o IPI e o ICMS. Nesse ponto, foi necessário abordar as diferenças entre materialidades econômicas daquelas contribuições (o faturamento e a receita) e os pressupostos de fato daqueles impostos (as operações). Estas questões são tratadas no Capítulo 2, que não tem a pretensão de criar uma nova classificação das espécies tributárias; pauta-se na classificação do CTN.

No Capítulo 3, abordamos os tributos sobre vendas/consumo, exemplos mais tradicionais de tributos incidentes sobre a circulação de riquezas, em cujo âmbito foi concebida a não-cumulatividade. No preâmbulo, cuidamos de esclarecer a diferença entre a

7 TORRES, Ricardo Lobo. Curso de direito financeiro e tributário. 11. ed. Rio de Janeiro: Renovar, 2004. p. 28. A nosso ver, em uma federação, o sistema tributário deve ter em mira também as relações entre os entes federados. 
translação econômica e a translação jurídica do encargo tributário, bem como de expor as razões da equiparação terminológica entre os tributos sobre vendas e os tributos sobre o consumo, observada tanto na economia como no direito tributário.

Ainda no Capítulo 3, tratamos dos diversos métodos de arrecadação dos tributos sobre vendas/consumo e de sua evolução histórica, dedicando itens específicos às experiências francesa e europeia com a tributação sobre o valor agregado, por terem inspirado a legislação do IPI e do ICMS. Ao tratar desses tradicionais impostos brasileiros arrecadados de forma não-cumulativa, enfrentamos a polêmica sobre ser a não-cumulatividade princípio ou regra.

Analisados os parâmetros brasileiros e estrangeiros da tributação não-cumulativa, foi possível examinar, no Capítulo 4, o PIS e a Cofins não-cumulativos, o sistema de descontos de créditos, a coexistência dos regimes cumulativo e não-cumulativo e os respectivos fatores de discrímen.

O Capítulo 5 indica, de forma sistemática, as conclusões do presente estudo. 


\section{A CIRCULAÇÃO DE RIQUEZA COMO FONTE TRIBUTÁVEL}

\subsection{Fontes de riqueza tributáveis e pressupostos de fato dos impostos}

No clássico A riqueza das nações, Adam Smith escreve que a renda de uma nação provém dos rendimentos da terra, do capital (lucros) e do trabalho (salários) ${ }^{8}$ e que, para extrair da sociedade as receitas necessárias ao financiamento de suas atividades, o Estado dispõe dos impostos, ${ }^{9}$ que podem gravar cada um desses rendimentos isoladamente, ou todos eles em conjunto.

A afirmativa de Smith de que os impostos gravam os rendimentos dos fatores de produção amolda-se ao sistema tributário brasileiro, que, por óbvio, não pode ser concebido desvinculado da realidade econômica. Como afirma Amílcar de Araújo Falcão, “quando a lei tributária indica um fato, ou circunstância, como capazes de, pela sua configuração, dar lugar a um tributo, considera esse fato em sua consistência econômica e o toma como índice de

8 SMITH, Adam. A riqueza das nações. São Paulo: Martins Fontes, 2003. v. 2, p. 1045. Tradução de Alexandre Amaral Rodrigues e Eunice Ostrensky.

9 A assertiva de Smith de que os impostos são coletados para que o Estado financie suas atividades remete ao tema da causa da tributação. Sem a intenção de ressuscitar o polêmico debate entre causalistas e anticausalistas, adotamos a lição de Ulhôa Canto, de que a lei é a fonte formal da obrigação tributária, causa efficiens, que responde à pergunta do "por força de quê” são devidos os tributos, e que as razões jurídicoeconômicas que determinaram a promulgação da lei são a causa final da obrigação tributária, ou seja, são a causa propriamente dita, que responde à pergunta de “por que são devidos os tributos” (CANTO, Gilberto de Ulhôa. Causa da obrigação tributária. Temas de direito tributário. Rio de Janeiro: Alba, 1964, v. 1, p. 329). Mas identificar a causa da obrigação tributária não significa desprezar a importância do que Paulo de Barros Carvalho, por todos, designa de "fenomenologia da incidência””: uma vez operada "a concreção do fato previsto na hipótese, propala(m-se) os efeitos jurídicos prescritos na conseqüência” e “[...] instala-se, automática e infalivelmente [...] o laço abstrato pelo qual o sujeito ativo torna-se titular do direito subjetivo público de exigir a prestação, ao passo que o sujeito passivo ficará na contingência de cumpri-la (CARVAlHO, Paulo de Barros. Curso de direito tributário. 17. ed. São Paulo: Saraiva, 2005. p. 250). Qualquer que seja a causa, ocorrido o fato gerador, impõe-se o dever de pagar o tributo. Sobre a causa final da obrigação tributária, recorremos à doutrina de Ezio Vanoni que, refutando as teorias do benefício e do sacrifício, diz que os tributos são devidos porque o Estado precisa de recursos para custear suas atividades e os cidadãos os pagam porque precisam daquelas atividades disponibilizadas pelo Estado. Essa teoria se distingue do contratualismo puro e simples de Griziotti (de quem Vanoni foi seguidor) por esclarecer que inexiste uma relação específica entre o tributo pago por um indivíduo específico e determinada atividade estatal a ele direcionada. Existe, sim, uma relação genérica entre o tributo pago e o serviço usufruído, que será individualizada na medida da capacidade contributiva de cada um. Capacidade contributiva é, portanto, medida da obrigação tributária, e não sua causa (VANONI, Ézio. Natureza e interpretação das leis tributárias. Tradução de Rubens Gomes de Sousa. Rio de Janeiro: Edições Financeiras, [s.d.]. p. 135-136). 
capacidade contributiva. A referência é feita, sempre, à relação econômica”. ${ }^{10}$ Ou, nas palavras de Ataliba e Giardino: “os tributos devem recair sobre fatos expressivos de significação econômica. [...]. O que se tributa - no sistema brasileiro - é o fato chamado por Becker de 'signo presuntivo de manifestações de riqueza'”. ${ }^{11}$

Mas a economia e o direito tributário abordam de formas distintas essas manifestações de riqueza tributável.

Em economia, como visto, a riqueza de uma nação equivale à sua produção interna, que pode ter dois destinos: consumo ou acumulação (poupança ou reinvestimento). Nesse sentido, os tributos recaem, em suma, sobre a renda consumida ou sobre a renda acumulada (poupada ou reinvestida). É o que se extrai quando Smith diz que, se o Estado tiver a intenção de tributar o conjunto dos rendimentos da nação, poderá fazê-lo por meio de impostos de capitação (per capita) ou por impostos incidentes sobre o consumo. A primeira forma se revela deficiente porque, na expressão de Smith, ${ }^{12}$ "o estado da fortuna de cada homem” sofre alterações diariamente e a tributação per capita, incidindo num determinado momento, não alcança essas variações. Parâmetro mais adequado se obtém quando o Estado lança mão do consumo para tributar indistintamente os rendimentos da nação. Isso porque, em linhas gerais, a tributação sobre o consumo equivale a uma tributação indireta sobre a renda, pois produz um aumento nos preços que diminui a renda do indivíduo na mesma proporção que o faria um tributo sobre a renda. E o consumo é critério mais adequado porque proporcional ao rendimento (quem ganha mais consome mais; quem ganha menos consome menos). ${ }^{13}$

10 FALCÃO, Amilcar. Interpretação e integração da lei tributária. Revista de Direito Administrativo, n. 40, p. 32, abr.-jun. 1955.

11 ATALIBA, Geraldo; GIARDINO, Cléber. PIS - Exclusão do ICM de sua base de cálculo. Revista de Direito Tributário, n. 35, p. 154-155 (destaques no original).

12 A riqueza das nações cit., p. 1104-1106.

13 Cf. Smith: "Parece que foi a impossibilidade de tributar o povo proporcionalmente a seu rendimento, mediante qualquer capitação, que deu origem à criação dos impostos sobre bens de consume. Sem saber como tributar direta e proporcionalmente o rendimento de seus súditos, o Estado procura taxá-lo indiretamente, tributando-lhe as despesas, as quais serão, na maioria dos casos, mais ou menos proporcionais ao rendimento de cada um. As despesas dos súditos são taxadas quando se tributam os bens de consumo que constituem essas despesas” (A riqueza das nações cit., 1.107). Em sentido contrário, Clara Sullivan: "Given the income inequality which characterizes most economic systems and the general rule that the proportion of consumption expenditures to income varies inversely with income levels, taxes which rest on consumption outlays only are regressive" (The tax on value added. Nova Iorque e Londres: Columbia University Press, 1959, 1965, p. 20). 
Já o direito tributário, a partir dessa mesma realidade - de que a renda, enquanto riqueza produzida por uma determinada nação, ou será acumulada ou será consumida -, vislumbra não uma, mas três fontes de riqueza tributáveis: a renda, o patrimônio e a circulação de riquezas. ${ }^{14}$

Tomemos como exemplo a venda de um automóvel realizada pelo fabricante.

Para os economistas, o imposto instituído sobre um produto industrializado, se pago pelo fabricante/vendedor, considera-se incidente sobre a receita originada da venda (riqueza produzida); se pago pelo adquirente, pode-se considerar incidente sobre o patrimônio (riqueza acumulada) ou sobre o consumo (riqueza consumida).

Ao analisar essa venda, o legislador federal pode indagar qual parcela do preço representa a renda do vendedor e exigir-lhe o IRPJ, hipótese em que a fonte alcançada será a renda produzida. Pode, ainda, vislumbrar na referida venda o último ato da industrialização e cobrar o IPI do vendedor, tributando a circulação de riqueza, ou seja, a riqueza produzida destinada ao consumo. Já o legislador estadual pode enxergar na referida operação o deslocamento da mercadoria para o consumo e gravá-la com o ICMS, tributando efetivamente a riqueza consumida. Esse mesmo legislador estadual pode, ainda, exigir o IPVA $^{15}$ do adquirente do automóvel, hipótese em que a tributação recairá sobre seu patrimônio, ou seja, sobre a riqueza acumulada.

O exemplo, por nós adaptado, foi colhido da tese de doutorado, apresentada à Pontifícia Universidade Católica de São Paulo, por José Antônio Minatel, que bem resume a interligação entre as realidades jurídica e econômica:

a contribuição compulsória dos particulares, desvinculada de contrapartida do poder público (imposto), só pode advir de realidade dotada de conteúdo

14 SOUSA, Rubens Gomes de. A tributação das vendas. Série Prática Fiscal n. 1. O imposto sobre vendas e consignações no sistema tributário brasileiro. Rio de Janeiro: Edições Financeiras, 1956. p. 7.

15 Lei 6.606/89, art. 1. : “O Imposto sobre a Propriedade de Veículos Automotores (IPVA), devido anualmente, tem como fato gerador a propriedade de veículo automotor de qualquer espécie. $\S 1 .^{\circ}$ Considera-se ocorrido o fato gerador do imposto em $1 .^{\circ}$ de janeiro de cada exercício. $\S 2 .^{\circ}$ Em se tratando de veículo novo, o fato gerador considera-se ocorrido na data da sua primeira aquisição”. 
econômico, quer seja qualificada juridicamente pela perspectiva da propriedade, quer pelo viés do consumo, da produção, circulação ou acumulação de riqueza [...]. ${ }^{16}$

\section{Melhor esclarecendo, Alcides Jorge Costa explica}

se quero me referir a um determinado fenômeno econômico, fica muito mais simples falar em sua forma jurídica, dizer que quero tributar as vendas ou quero tributar as consignações e por aí afora, daí já se entende o que é . ${ }^{17}$

Vale dizer, de cada uma das três tradicionais fontes de riqueza tributáveis (renda, patrimônio e circulação de riquezas) o direito tributário colhe determinadas parcelas que, por revelarem capacidade econômica, podem ser tributadas. Essas parcelas da realidade econômica são, para os impostos, ${ }^{18}$ os pressupostos de fato, ${ }^{19}$ que serão qualificados pelo legislador como fatos geradores. ${ }^{20}$

16 MINATEL, José Antônio. Conteúdo do conceito de receita e regime jurídico para sua tributação. 2005. Tese (Doutorado) - PUC, São Paulo, p. 58. A tese deu origem a livro com o mesmo título, publicado em São Paulo, pela MP editora, em 2005, com 270 p.

17 A competência tributária e o novo Código Civil. In: BORGES. Eduardo de Carvalho (Coord.). Impacto tributário do novo Código Civil. São Paulo: Quartier Latin/IPT, 2004. Apud CANADO, Vanessa. As regrasmatrizes de incidência tributária da Contribuição para o Financiamento da Seguridade Social (Cofins) nos regimes "cumulativo", "não-cumulativo", de "incidência monofásica" e de "substituição tributária", previstos na Lei Complementar n. 70/91 e nas Leis n. 9.178/98, n. 10.147/00, n. 10.485/02, n. 10.560/02 e n. 10.833/03. 2008. Dissertação (Mestrado) - PUC, São Paulo. p. 132, nota 174.

18 Discorreremos, em item específico, sobre a relevância dessa parcela de realidade econômica reveladora de capacidade contributiva para as contribuições sociais.

19 Marco Aurélio Greco, recordando Enrico de Mita e Gian Antonio Micheli diz que o pressuposto de fato é "o fundamento a partir do qual a legislação poderá escolher fatos que irão provocar o nascimento das situações jurídicas subjetivas que vinculam o Fisco e contribuintes, dentre as quais a obrigação tributária” (Nãocumulatividade no PIS e na Cofins. In: PAULSEN, Leandro (Coord.) et al. Não-cumulatividade do PIS/Pasep e da Cofins. São Paulo: IOB Thompson; Porto Alegre: Instituto de Estudos Tributários, 2004. p. 106).

20 Inúmeras são as críticas da doutrina brasileira à expressão fato gerador tributário, por confundir, num só conceito, as fontes formal e material do direito. Misabel Derzi assim as resume: “A. A. Becker, em lugar da expressão fato gerador, sugere hipótese realizada [...]; G. Ataliba propõe hipótese de incidência e fato imponível [...]; Barros Carvalho se utiliza, por sua vez, dos termos hipótese e fato jurídico [...]" (Direito tributário, direito penal e tipo. 2. ed. rev. e atual. São Paulo: Revista dos Tribunais, 2007 p. 252, nota 167). Apesar de cientes dessas críticas e de sua importância para a construção do direito tributário, utilizaremos no presente estudo a expressão fato gerador, cunhada pelo CTN. 
Como a mesma fonte de riqueza enseja diversos pressupostos de fato e, tendo em vista que "o mesmo pressuposto de fato pode comportar a definição em lei de vários fatos geradores diferentes”, ${ }^{21}$ sua compreensão é importante para análise de qualquer tributo.

\subsection{Classificação dos impostos no CTN: agrupamento conforme as fontes de riqueza tributáveis}

Ao delinear o sistema tributário brasileiro, a CF/88 atribuiu relevância ao aspecto econômico dos pressupostos de fato dos impostos.

É verdade que, ao discriminar as competências tributárias de cada ente político, o constituinte de 1988 mirou apenas a perspectiva histórica, repetindo critérios das constituições anteriores, sem cuidar de investigar os fundamentos econômicos dessa repartição nem de procurar novas fontes de riqueza tributáveis, centrando suas preocupações “em preservar o princípio maior da Federação e manter incólume a autonomia municipal”. ${ }^{22}$

Não obstante, os arts. 153, 155 e 156 da CF/88 ${ }^{23}$ indicam exatamente a parcela de riqueza que cada ente político pode exigir dos contribuintes por intermédio da tributação. "Retratam específica realidade recortada pelo legislador constituinte, particularizada pelo conteúdo econômico e natureza dos eventos que o próprio ordenamento já qualifica como imprescindíveis para exteriorizá-lo.”24

21 GRECO, Marco Aurélio. Não-cumulatividade no PIS e na Cofins cit., p. 107.

22 CARVALHO. Paulo de Barros. Curso de direito tributário, cit. p. 29.

23 “Art. 153. Compete à União instituir impostos sobre: I - importação de produtos estrangeiros; II exportação, para o exterior, de produtos nacionais ou nacionalizados; III - renda e proventos de qualquer natureza; IV - produtos industrializados; V - operações de crédito, câmbio e seguro, ou relativas a títulos ou valores mobiliários; VI - propriedade territorial rural; VII - grandes fortunas, nos termos de lei complementar. [...]; Art. 155. Compete aos Estados e ao Distrito Federal instituir impostos sobre: I transmissão causa mortis e doação, de quaisquer bens ou direitos; II - operações relativas à circulação de mercadorias e sobre prestações de serviços de transporte interestadual e intermunicipal e de comunicação, ainda que as operações e as prestações se iniciem no exterior; III - propriedade de veículos automotores. [...]; Art. 156. Compete aos Municípios instituir impostos sobre: I - propriedade predial e territorial urbana; II - transmissão "inter vivos”, a qualquer título, por ato oneroso, de bens imóveis, por natureza ou acessão física, e de direitos reais sobre imóveis, exceto os de garantia, bem como cessão de direitos a sua aquisição; III - serviços de qualquer natureza, não compreendidos no art. 155, II, definidos em lei complementar.”

24 MINATEL, José Antônio. Conteúdo do conceito de receita... cit., p. 108. 
Luis Eduardo Schoueri explica a relevância do aspecto econômico do pressuposto de fato dos impostos para balizar (i) a repartição de competências tributárias e (ii) os limites à competência residual da União para instituir de novos impostos. ${ }^{25}$

Invocando o parecer da Comissão da Reforma do Ministério da Fazenda que concebeu a EC 18/65, relata o referido autor que a classificação ali proposta, ao consolidar “os impostos de idênticas naturezas em figuras unitárias por via de referência às suas bases econômicas, antes que a uma das modalidades jurídicas que pudessem revestir”, ${ }^{26}$ tinha o intuito de impedir que os entes políticos viessem a instituir outros impostos além daqueles arrolados no texto constitucional ${ }^{27}$. Expressando esse intuito, o art. $5^{\circ}$ da EC 18/65 dizia que “os impostos componentes do sistema tributário nacional são exclusivamente os que constam desta Emenda, com as competências e limitações nela previstas.”

Mas esse impedimento ao exercício de novas competências tributárias teve curta duração, pois, logo em seguida, o constituinte de 1967 autorizou a União a criar novos impostos, desde que não tivessem fatos geradores nem bases de cálculo iguais aos já existentes (cf. art. 21 da CF 67/69 ${ }^{28}$ ). Com esse dispositivo, o critério para identificação e distinção de impostos pelo qual se orienta a repartição de competências tributárias e o exercício da competência residual da União deixou de ser a perspectiva econômica do pressuposto de fato e passou a ser a conjugação do binômio fato gerador e base de cálculo ${ }^{29}$, que subsistem na atual ordem constitucional ${ }^{30}\left(\mathrm{CF} / 88^{31}\right)$.

25 SCHOUERI, Luis Eduardo. Discriminação de competências e competência residual. In: ; ZILVETI, Fernando Aurélio (Coord.). Estudos em homenagem a Brandão Machado. São Paulo: Dialética, 1998. p. 83115. De acordo com Bernardo Ribeiro de Moraes, o sistema constitucional anterior à EC 18/65 adotara a classificação nominalística-jurídica dos impostos, "fazendo os impostos se diferenciarem apenas pela roupagem jurídica, sem qualquer alusão ao conteúdo econômico (Compêndio de direito tributário. 4. ed. Rio de Janeiro: Forense, 1995. p. 155).

26 LOPES, Luis Simões (Presidente da Comissão) et al. Reforma da discriminação constitucional de rendas (anteprojeto). Publicação n. 6, Fundação Getúlio Vargas e Comissão de Reforma do Ministério da Fazenda, 1965, p. 6. Apud SCHOUERI, Luis Eduardo. Estudos em homenagem a Brandão Machado cit., p. 86.

27 Expectativa que, como sabemos, restou frustrada.

28 Idem, ibidem.

29 Aliomar Baleeiro, tratando da CF 67/69, em lição perfeitamente aproveitável para a CF/88, afirma que "fato gerador e base de cálculo [...] fornecem o elemento fundamental para a identificação, a classificação, e a 
Ainda segundo o referido autor, apesar da mudança de critério, a análise dos pressupostos de fato como parcelas da realidade econômica alcançadas pela tributação continua sendo importante para distinguir um imposto de outro. Isso porque, como o fato gerador e a base de cálculo qualificam, juridicamente, a realidade econômica tributável, então, ao estabelecer que os impostos criados por meio da competência residual da União não podem ter o mesmo fato gerador nem a mesma base de cálculo de outros já existentes, o constituinte quis dizer que a União não pode exigir do contribuinte mais de um imposto sobre um mesmo objeto econômico.

Com apoio em Klaus Tipke, ${ }^{32}$ Schoueri conclui: a finalidade na identificação de um critério para distinguir se um imposto é igual a outro é coibir a tributação excessiva, decorrente da pluritributação. Essa a ratio da rígida repartição de competências tributárias e da fixação de parâmetros igualmente inflexíveis para o exercício da competência residual pela União. Sendo assim, a análise do aspecto econômico do pressuposto de fato dos impostos, que Tipke denomina "componente da capacidade econômica do contribuinte a qual se conecta o imposto", 33 é o critério que impedirá que a mesma manifestação de riqueza dos contribuintes seja tributada mais de uma vez, seja pelo mesmo ente político (e aí sua relevância para o exercício da competência residual da União), seja por outro ente da Federação (donde sua importância na repartição de competências tributárias).

Justamente para evitar a tributação excessiva de uma mesma fonte de riqueza, o legislador constituinte, ao editar a EC 18/65 - que concebeu o sistema tributário nacional tal

diferenciação dos impostos [...]” (Limitações constitucionais ao poder de tributar. Atualizado por Misabel Abreu Machado Derzi. 7. ed. Rio de Janeiro: Forense, 1997. p. 116).

30 Doutrina diverge sobre ser a base de cálculo realmente apta a identificar o aspecto material do tributo. Para Roque A. Carrazza (ICMS - Inconstitucionalidade da inclusão de seu valor, em sua própria base de cálculo. Revista Dialética de Direito Tributário, n. 23, p. 96-98, São Paulo: Dialética), “a base de cálculo é índice seguro para identificar o aspecto material da hipótese de incidência tributária. É ela que confirma ou infirma a natureza jurídica do tributo”. Em sentido contrário: ROCHA, Valdir de Oliveira. Determinação do montante do tributo - Quantificação, fixação e avaliação. 2. ed. São Paulo: Dialética, 1995. p. 152: “A base de cálculo pode, em certas circunstâncias, confirmar o aspecto material do fato gerador do tributo. Essa função confirmatória possível é eventual. A base de cálculo não indica a natureza jurídica do tributo; pelo contrário, base de cálculo inadequada pode descaracterizar natureza jurídica”.

31 “Art. 154. A União poderá instituir: I - mediante lei complementar, impostos não previstos no artigo anterior, desde que sejam não-cumulativos e não tenham fato gerador ou base de cálculo próprios dos discriminados nesta Constituição”.

32 “Über die Gleichartigkeit von Steuern”, in Steuer und Wirtschaft, 3/1975, p. 242-251. Apud SCHOUERI, Estudos em homenagem a Brandão Machado cit., p. 105-107.

33 SCHOUERI, Luis Eduardo. Estudos em homenagem a Brandão Machado cit., p. 107. 
como hoje o conhecemos -, agrupou os impostos em quatro classes: impostos sobre o comércio exterior, impostos sobre o patrimônio e a renda; impostos sobre a produção e a circulação e impostos especiais. O CTN, contemporâneo à EC 18/65, repetiu esses critérios.

A classificação coincide, em linhas gerais, com aquela tradicional repartição das fontes de riqueza tributáveis (patrimônio, renda e circulação de riquezas). A diferença é que agrupa, sob o mesmo título, os impostos incidentes sobre o patrimônio e a renda - porque traduzem categorias jurídicas mais padronizadas. ${ }^{34}$ Além disso, separa os impostos incidentes sobre a circulação de riquezas (produção e circulação) daqueles incidentes sobre as operações de comércio exterior, alinhando-se, nesse ponto, à doutrina alemã, que estabelece a diferença entre os impostos de consumo - que incidem sobre a circulação de bens - dos impostos sobre o tráfico, que tributam os fatos importação e exportação. ${ }^{35} \mathrm{O}$ grupo dos impostos especiais reserva-se para aqueles com características técnicas particulares e para os de caráter extraordinário. $^{36}$

Com a autoridade de relator do projeto que deu origem à EC 18/65 $5^{37}$ e de coautor do CTN, Rubens Gomes de Sousa resume a relevância da análise da realidade econômica para análise dos impostos, notadamente para aqueles incidentes sobre a circulação de riquezas:

A rigor, somente um imposto que recaia sobre a transmissão da propriedade
corresponde exatamente ao conceito econômico de um tributo sobre a
circulação de riquezas. O imposto cobrado em função da produção poderia
incidir sobre o patrimônio do produtor, ou sobre o rendimento evidenciado
pelo acréscimo de valor patrimonial decorrente da transformação industrial;
ao passo que a tributação do consumo poderia gravar economicamente o
rendimento, no momento em que este se torna aparente pelo seu dispêndio.

34 SOUSA, Rubens Gomes de. A tributação das vendas cit., p. 7.

35 Cf. TORRES, Ricardo Lobo. É possível a criação do IVA no Brasil? In: SARAIVA FILHO. Oswaldo Othon de Pontes; VASQUES. Sérgio; GUIMARÃES, Vasco Branco (Org.). IVA para o Brasil: contributos para a reforma da tributação do consumo. Belo Horizonte: Fórum, 2007. p. 30: "Sempre se reconheceu em doutrina a incidência dos impostos internos de consumo sobre a importação. Distinguem-se eles do imposto de importação porque são impostos de consumo, a incidirem sobre a circulação internacional de bens, e não sobre o fato de importação". Idem, ibidem, nota 17: "Os alemães estabelecem a diferença entre os Verbrauchsteuern (impostos de consumo) e os Verkerhrsteuern (impostos sobre o tráfico). Tipke e Lang caracterizam o imposto sobre a circulação (Umsatzsteuer) como 'um imposto de consumo: ele é o imposto geral de consumo (die algemeine Verbrauchsteuer)".

36 Cf. FRANCISCO NETO, João. Evolução histórica dos tributos. 2005. Dissertação (Mestrado) - USP, São Paulo, p. 119.

37 A “paternidade” do CTN é atribuída a Rubens Gomes de Sousa e Gilberto de Ulhôa Canto. 
Todavia, cumpre distinguir entre um imposto incidente sobre o produtor pelo simples fato de haver produzido, e um imposto que tributa a produção pelo fato de ser posta em circulação. Como, também, importa diferençar, entre os impostos assentes sobre o consumo, os que tomam o consumo simplesmente como índice de riqueza já possuída pelo consumidor, daqueles que 0 consideram como a fase final do ciclo desenvolvido pela riqueza em circulação.

Esta distinção não é especiosa porque meramente inspirada no formalismo jurídico, mas ao contrário relacionada com o substrato econômico das diferentes incidências consideradas. Assim, o imposto sobre a riqueza produzida é imposto sobre o patrimônio, porque nele o fundamento econômico da tributação e o momento jurídico da incidência se confundem; mas o imposto sobre a riqueza produzida e lançada ao consumo é imposto sobre a circulação da riqueza, porque esta é o seu fundamento econômico, e a produção é apenas o momento jurídico da incidência. Invertendo o raciocínio, o mesmo se pode dizer do imposto cobrado daquele que aliena o patrimônio, ou renda incorporada ao patrimônio, em confronto com o imposto cobrado daquele que adquire riqueza nova no momento final de seu processo circulatório.

Em resumo, posta de parte a hipótese típica do imposto incidente sobre a transmissão de propriedade, que por isso mesmo não oferece problema de conceituação, um imposto sobre a circulação da riqueza pode também incidir, indiferentemente, no momento inicial da circulação (produção), ou no seu momento final (consumo), sem por isso perder a sua natureza econômica. O traço essencial da caracterização está em apurar, em cada caso, se a produção ou o consumo, constituem a própria base econômica da tributação, ou apenas o momento adotado para a incidência jurídica. ${ }^{38}$

Essas lições de Rubens Gomes de Sousa serão importantes para entender a fonte de riqueza tributada pelas contribuições objeto do presente estudo e sua nãocumulatividade.

\subsubsection{O grupo de impostos sobre a produção e a circulação}

No Capítulo IV do Título III do Livro Primeiro, o CTN agrupou, sob a denominação de Impostos sobre a Produção e a Circulação, os fatos geradores do Imposto sobre Produtos Industrializados, dos Impostos Relativos à Circulação de Mercadorias, do Imposto sobre Imposto sobre Operações de Crédito, Câmbio e Seguro, e sobre Operações Relativas a Títulos e Valores Mobiliários, do antigo Imposto sobre Serviços de Transportes e Comunicações e do Imposto sobre Serviços de Qualquer Natureza.

38 A tributação das vendas cit., p. 7-8 (destaques nossos). 
A produção a que o CTN alude nesse grupo de impostos não é aquela que, na lição de Rubens Gomes de Sousa, conduz à perspectiva estática dos tributos sobre o patrimônio, pois esses pertencem a grupo próprio, descrito no Capítulo III daquele título, ${ }^{39}$ figurando ao lado daqueles incidentes sobre a renda, que é justamente acréscimo patrimonial disponível. ${ }^{40}$

Tampouco a circulação a que alude esse grupo econômico de impostos deve ser considerada nos limites estreitos do deslocamento de mercadorias da fonte produtiva ao consumo, pois o CTN arrola, sob a mesma epígrafe (impostos sobre a produção e a circulação), os impostos sobre operações de crédito, câmbio e seguro e sobre operações relativas a títulos e valores mobiliários, as quais não têm em mira o deslocamento de mercadorias.

Para entender o sentido da produção e da circulação às quais o CTN alude nesse Capítulo IV, recorremos às lições de Carnelutti sobre a noção econômica de circulação, sintetizadas por Alcides Jorge Costa. ${ }^{41}$

Explica o tributarista brasileiro que, de acordo com catedrático italiano, o processo econômico tem duas fases elementares: a produção e a distribuição. Quem produz desloca o bem produzido para outrem, que dele vai usufruir. A circulação é justamente esse deslocamento, uma subespécie da distribuição.

Quatro são as formas fundamentais de circulação: o escambo, o crédito, a associação e a cessão. Todas elas têm como elementos comuns a existência de duas pessoas e de um bem, que pode ser corpóreo, incorpóreo, móvel ou imóvel.

Na associação, duas pessoas usufruem o bem em conjunto. A conferência de bens em integralização de capital de uma empresa é o exemplo de associação citado por Alcides Jorge Costa. No escambo, o possuidor autoriza a fruição da coisa por outrem, sem perspectiva

39 O Capítulo III do Título III do Livro Primeiro do CTN trata dos Impostos sobre o Patrimônio e a Renda.

40 Cf. conclusão de Roberto Quiroga Mosquera: “Falar em disponibilidade econômica ou jurídica é o mesmo que falar em acréscimo de elementos patrimoniais, uma vez que a partir do momento em que um determinado indivíduo tem acrescido ao seu patrimônio um direito, ele passa a ter uma relação de propriedade com esse bem, podendo, conseqüentemente, usá-lo, fruí-lo e dele dispor; [...]” (Renda e proventos de qualquer natureza. São Paulo: Dialética, 1996. p. 136).

41 Teoria giuridica della circolazione. Padova: Cedam, 1933, capítulo introdutório. Apud COSTA, Alcides J. ICM - Estrutura na Constituição e na lei complementar. São Paulo: Irmãos Milesi, 1977. p. 81. 
de tê-la de volta. Doação e venda são, respectivamente, os exemplos de escambo gratuito e oneroso lembrados pelo autor, aos quais podemos acrescentar o contrato de câmbio que, referindo-se à compra e venda de moeda, também se enquadra como escambo oneroso. No crédito, o possuidor receberá de volta o bem que autorizou o outro a usufruir. Alcides Jorge Costa indica como exemplos desse tipo de circulação o comodato e a locação, que correspondem, respectivamente, a crédito gratuito e a crédito oneroso, ao que acrescentamos o próprio contrato de crédito, em que o credor faz circular o dinheiro, na perspectiva de tê-lo de volta, acrescido de juros. Por fim, na cessão, uma pessoa antecipa a fruição de bem que só poderia usufruir no futuro. É o que ocorre na cessão de crédito, em que o credor que emprestou dinheiro faz-se substituir por outrem, cedendo-lhe a expectativa que tem de usufruir, oportunamente, o bem - v.g. dinheiro - que havia circulado na operação de crédito anterior.

Dessa explanação julgamos apropriado colher um terceiro elemento comum às formas fundamentais de circulação econômica descritas por Carnelutti: a fruição do bem, que também pode ser entrevista como consumo, conceito que, na linguagem econômica, está atrelado à utilização do bem, seja para satisfazer uma necessidade imediata, seja para satisfazer uma necessidade mediata, v.g., sua utilização como insumo de atividades empresariais. $^{42}$

Em resumo, a circulação econômica engloba tanto as fases elementares do ciclo econômico - produção e distribuição - como operações de circulação mais sofisticadas, em que a riqueza produzida por determinado agente econômico é deslocada para fruição de outrem. Equivale, portanto, à circulação de riquezas, que, como explicou Rubens Gomes de Sousa, ${ }^{43}$ compreende a riqueza produzida e a riqueza consumida no ciclo de operações que promovem o giro da economia.

Nessa circulação de riquezas, enquanto fonte tributável, podemos entrever diversos pressupostos de fato: as mercadorias, os bens e os serviços; sua industrialização, distribuição, venda, prestação e consumo, as contraprestações pelas referidas operações, que materializam receita para o agente econômico, enfim, uma gama de realidades reveladoras de

42 Cf. SOUZA, Washington Peluso Albino de. Primeiras linhas de direito econômico. 2. ed., atual. por Terezinha Helena Linhares. Belo Horizonte: Fundação Brasileira de Direito Econômico, 1992. p. 361.

43 A tributação das vendas cit., p. 8. 
significação econômica que poderão ser qualificadas juridicamente como fatos geradores dos mais diversos tributos incidentes sobre a circulação de riquezas.

Firme nessas considerações, ao tratar da estrutura do ICM na Constituição de 67/69, concluiu Alcides Jorge Costa $^{44}$ que um conceito tão amplo não se coadunava com aquele imposto, cujo fato gerador era realizar a série de operações que conduzem a mercadoria da fonte de produção ao consumo - ou seja, o imposto estadual então analisado pelo mencionado tributarista tinha por pressuposto de fato operações de circulação (subespécie da distribuição) que impulsionam a mercadoria ao consumo.

Já a produção, etapa inicial e elementar do ciclo econômico, é o pressuposto de fato do IPI, que tributa o produto industrializado sob a perspectiva explicitada por Rubens Gomes de Sousa linhas atrás, de que será ulteriormente lançado ao consumo. ${ }^{45}$ Portanto, no Brasil, ICMS e IPI tributam aquilo que Carnelutti designou de fases elementares do processo econômico (produção e distribuição).

Mas, como visto, a abrangência do conceito econômico de circulação remete a outras operações. Nessa amplitude, é possível entrever não só aquilo a que Alcides Jorge Costa, citando Carnelutti, referiu-se como fases elementares do ciclo econômico (produção e distribuição), mas também operações relacionadas à produção de outras riquezas (além das mercadorias e determinados serviços) e seu direcionamento para fruição por terceiros. É o caso das riquezas geradas a partir das operações de câmbio, seguro, crédito e valores mobiliários, ${ }^{46}$ cujos fatos geradores, exatamente por isso, figuram sob a mesma epígrafe que os fatos geradores do IPI e do ICMS: impostos sobre a produção e a circulação.

44 Discorrendo sobre o ICM, Alcides Jorge Costa diz que seu fato gerador "é o encaminhamento da mercadoria em direção ao consumo [...]” (ICM - Estrutura na Constituição e na lei complementar cit. p. 88). A nosso ver, o entendimento amolda-se também ao ICMS, com o diferencial de que não só a mercadoria, mas também determinados serviços são direcionados ao consumo por meio das operações de circulação tributadas por esse imposto, que sucedeu o ICM.

45 Daí o Dec. 4.544/2002, que regulamenta o IPI, arrolar como “fatos geradores” do IPI operações que exteriorizam o seu direcionamento ao consumo da mercadoria industrializada, tais o desembaraço aduaneiro da mercadoria industrializada estrangeira e a saída dos estabelecimentos do industrial ou equiparado e do importador. Confira-se: “Art. 34. Fato gerador do imposto é (Lei 4.502, de 1964, art. 2. ${ }^{\circ}$ ): I - o desembaraço aduaneiro de produto de procedência estrangeira; ou II - a saída de produto do estabelecimento industrial, ou equiparado a industrial”.

46 “Art. 63. O imposto, de competência da União, sobre operações de crédito, câmbio e seguro, e sobre operações relativas a títulos e valores mobiliários tem como fato gerador: I - quanto às operações de crédito, 
De tudo isso podemos extrair que a produção e a circulação abordadas no Capítulo IV do Título III do Livro Primeiro do CTN (Impostos sobre a Produção e a Circulação) remetem à noção ampla de circulação econômica a que se refere Carnelutti e à fonte de riqueza tributável que a doutrina tributária tradicionalmente denomina circulação de riquezas.

Usando as palavras de Rubens Gomes de Sousa já anteriormente transcritas: os impostos agrupados no referido capítulo têm em mira a "riqueza produzida e lançada ao consumo [...]” sendo "a circulação da riqueza [...] seu fundamento econômico". 47

a sua efetivação pela entrega total ou parcial do montante ou do valor que constitua o objeto da obrigação, ou sua colocação à disposição do interessado; II - quanto às operações de câmbio, a sua efetivação pela entrega de moeda nacional ou estrangeira, ou de documento que a represente, ou sua colocação à disposição do interessado em montante equivalente à moeda estrangeira ou nacional entregue ou posta à disposição por este; III - quanto às operações de seguro, a sua efetivação pela emissão da apólice ou do documento equivalente, ou recebimento do prêmio, na forma da lei aplicável; IV - quanto às operações relativas a títulos e valores mobiliários, a emissão, transmissão, pagamento ou resgate destes, na forma da lei aplicável.”

47 A tributação das vendas cit., p. 8. 


\section{A FONTE DE RIQUEZA TRIBUTADA PELO PIS E PELA COFINS NÃO-CUMULATIVOS}

\subsection{As materialidades econômicas das contribuições sociais de seguridade social}

Até agora, tratamos dos pressupostos de fato dos impostos. Estreitando o foco para o objeto do presente estudo, passemos a analisar as contribuições sociais, tais o PIS e a Cofins não-cumulativos.

Que as contribuições sociais são tributos, disso não há mais dúvidas, pois o Supremo Tribunal Federal acolheu a lição doutrinária e classificou-as como tais, ${ }^{48}$ tendo esclarecido que PIS/Pasep e Cofins pertencem à subespécie das contribuições sociais seguridade social. ${ }^{49}$

Geraldo Ataliba, seguido de outros importantes doutrinadores, ${ }^{50}$ classificou as contribuições como tributos vinculados, ${ }^{51}$ por entender que o aspecto material de sua hipótese

48 RE 138.284-8/CE, Rel. Min. Carlos Velloso, julgamento em 1.․07.1992, DJU 28.08.1992. Transcrevemos o trecho do voto do Min. Carlos Velloso que já se tornou clássico no direito tributário brasileiro: “As diversas espécies tributárias, determinadas pela hipótese de incidência ou pelo fato gerador da respectiva obrigação (CTN, art. 4. ${ }^{\circ}$ ), são as seguintes: a. os impostos (CF, arts. 145, I, 153, 154, 155 e 156); b. as taxas (CF art. 145, II); c. as contribuições, que podem ser assim classificadas: c.1. de melhoria (CF, art. 145, III); c.2 parafiscais (CF, art. 149), que são: c.2.1 sociais, c.2.1.1 de seguridade social (CF, art. 195, I, II, III), c.2.1.2 outras de seguridade social (CF, art. 195, parág. 4. ․), c.2.1.3 sociais gerais (o FGTS, o salário-educação, CF, art. 212, § 5. ${ }^{\circ}$, contribuições para o Sesi, Senai, Senac, CF, art. 240); c.3 especiais: c.3.1 de intervenção no domínio econômico (CF, art. 149) e c.3.2 corporativas (CF, art. 149). Constituem, ainda, espécie tributária: d) os empréstimos compulsórios (CF, art. 148)”.

49 A classificação da Cofins como contribuição social de seguridade social foi referendada pelo STF no julgamento da ADC 1-1/DF, julgamento em 1. ‥12.1993, DJU 16.06.1995, Rel. Min. Moreira Alves, verbis: “o art. 1. ${ }^{\circ}$ da Lei Complementar n. 70/91, instituiu contribuição social para financiamento da Seguridade Social, nos termos do inciso I do art. 195 da Constituição Federal [...]”. Quanto ao PIS/Pasep, o Min. Velloso assim se manifestou no já citado RE 138.284-8/CE: “O PIS e O Pasep passam, por força do disposto no art. 239 da Constituição, a ter destinação previdenciária. Por tal razão, as incluímos entre as contribuições de seguridade social. Sua exata classificação seria, entretanto, ao que penso, não fosse a disposição inscrita no art. 239 da Constituição, entre as contribuições sociais gerais”.

50 Exemplificativamente: COELHO, Sacha Calmon Navarro. Cientista do direito - Reflexões sobre a hipótese de incidência dos tributos - Substitutos e responsáveis tributários no direito brasileiro. Revista Dialética de Direito Tributário, São Paulo: Dialética, n. 8, p. 112: “Fatos estatais não geram impostos, somente taxas e contribuições de melhoria; fatos do contribuinte, demonstrativos de capacidade contributiva, ou sejam impostos (finalísticos ou não, afetados ou não)”.

51 A clássica repartição preconizada por Ataliba divide os tributos em vinculados e não vinculados a uma ação estatal. Se o aspecto material da hipótese de incidência consiste "numa atividade do poder público (ou numa repercussão desta)” o tributo será vinculado. Se o aspecto material "consiste num fato ou acontecimento 
de incidência, que o CTN denomina fato gerador, é uma atividade estatal referida ao obrigado ou uma decorrência do status ou da atividade do obrigado, que provoca uma ação estatal a ele referida. A atividade estatal referida ao contribuinte - e não a parcela da realidade econômica reveladora de riqueza tributável - foi o fator relevante para a classificação preconizada por esse autor.

Todavia, após a CF/88, a referibilidade ao contribuinte, direta ou indireta, deixou de ser fator determinante para conceituar as contribuições sociais, haja a vista a previsão do art. 195 caput de que a seguridade social será financiada por todos, por meio de diversas contribuições. As contribuições, como quaisquer tributos são, atualmente, devidas em virtude do princípio da solidariedade social, independentemente de referibilidade.

Marco Aurélio Greco, por fundamento diverso, chegou à mesma conclusão (de que as contribuições são desvinculadas da ação estatal), incluindo as contribuições no grupo de tributos cujo aspecto econômico não é o critério determinante de validade. ${ }^{52}$ Segundo esse autor, enquanto para os impostos (exceto os de guerra), as taxas e as contribuições de melhoria, “a Constituição autoriza a criação de determinado tributo 'por que' ocorreu determinado fato ou foi exercida certa atividade [...]”, sendo “o referencial básico de atribuição da competência a existência de uma daquelas materialidades”, nas contribuições, a preocupação com essa materialidade é secundária, pois correspondem ao instrumento de atuação da União na área social, econômica ou das categorias profissionais e, por isso, buscam seu fundamento de validade na finalidade ou objetivo a que visam.

Mas isso não significa que as contribuições não tenham pressupostos de fato; significa apenas que, ao contrário do que ocorre com os impostos, seus pressupostos de fato definidos, pelo referido autor, como as parcelas da realidade alcançadas pela tributação - não são recortados da realidade econômica, como nos impostos, mas sim de alguma outra

inteiramente indiferente a qualquer atividade estatal”, o tributo será não-vinculado. Nessa linha, os impostos são tributos não vinculados, pois seu aspecto material são realidades econômicas indiferentes à atuação estatal. Taxas e contribuições, cujo aspecto material relaciona-se nitidamente com uma atividade estatal, são tributos vinculados. E conclui Ataliba, dizendo que as contribuições "são espécie de tributo vinculado, ao lado da taxa. Desta se distinguem por um quid plus na estrutura da materialidade da h.i (hipótese de incidência) [...] e principalmente pela base imponível”. Esse quid plus na estrutura da materialidade é a "atuação estatal indireta e mediatamente referida ao obrigado, isto é, mediante uma circunstância intermediária” (ATALIBA, Geraldo. Hipótese de incidência tributária. 6. ed., 6. tir. São Paulo: Malheiros, 2005. p. 130 e 183).

52 GRECO, Marco Aurélio. Contribuições (uma figura “sui generis”). São Paulo: Dialética, 2000. p. 131-139. 
realidade “escolhida pela Constituição para atribuir competência tributária ou decorrente de uma finalidade constitucionalmente qualificada". 53

Esse mesmo autor conclui que, embora o aspecto econômico seja sua nota menos relevante, como as contribuições são tributos, a norma que as institui tem caráter obrigacional. ${ }^{54}$ Por isso a lei descreve as circunstâncias que ensejam o nascimento da correspondente obrigação tributária, vale dizer, designa os respectivos fatos geradores e aponta os critérios de dimensionamento da obrigação, entre os quais as respectivas bases de cálculo. ${ }^{55}$

É dizer, os pressupostos de fato das contribuições sociais são as parcelas da realidade social, econômica, de interesse das categorias, etc. e as finalidades que a Constituição elege como relevantes para validar sua instituição; as parcelas da realidade econômica sobre a qual recaem as contribuições (ou sua materialidade) integram suas normas de incidência, mas não são seus pressupostos de fato.

Portanto, no presente estudo, quando nos referirmos às realidades econômicas sobre as quais recaem os impostos, falaremos em pressupostos de fato, mas, quando tratarmos da realidade econômica subjacente às contribuições, utilizaremos a expressão materialidade econômica, inspirada na linguagem proposta por Marco Aurélio Greco.

Feito esse esclarecimento, verificamos, como já ressaltado no item 1.2, que, ao delimitar os pressupostos de fato dos impostos, a CF/88 reservou a cada ente político sua respectiva competência privativa, com a intenção de garantir-lhes a autonomia e evitar não só conflitos de competência, mas também a indevida "ampliação do espectro de incidência”, 56

53 Confiram-se as palavras do autor: "pressuposto de fato [é] a parcela da realidade a ser alcançada pelo tributo. É alguma realidade denotativa de capacidade contributiva (para os impostos), uma determinada atividade estatal (para as taxas) ou alguma outra materialidade escolhida pela Constituição para atribuir competência tributária ou decorrente de uma finalidade constitucionalmente qualificada” (GRECO, Marco Aurélio. Nãocumulatividade no PIS e na Cofins cit., p. 196.

54 Pagar tributos é ato que deriva de relação jurídica de direito público de natureza obrigacional e a obrigação daí resultante (obrigação tributária) tem cunho patrimonial. Esse caráter obrigacional do tributo foi reconhecido pelo direito positivo brasileiro, a teor do art. 3. ${ }^{\circ}$ do CTN, que dispõe: “Tributo é toda prestação pecuniária compulsória, em moeda ou cujo valor nela se possa exprimir, que não constitua sanção de ato ilícito, instituída em lei e cobrada mediante atividade administrativa plenamente vinculada”.

55 GRECO, Marco Aurélio. Contribuições (uma figura “sui generis”) cit., p. 146-50.

56 A expressão foi usada por Vanessa Canado, As regras-matrizes... cit., p. 124. 
prejudicial aos contribuintes. Além disso, conferiu ao contribuinte a segurança de que só a União pode criar outros impostos e, mesmo assim, apenas em hipóteses restritas, como a iminência de guerra externa ou sua efetiva ocorrência, ou, nos casos de competência residual, se o legislador federal encontrar novas fontes de riqueza distintas das já indicadas. ${ }^{57}$

No tocante às contribuições sociais, a CF/88 não precisou ocupar-se disso, seja porque, como afirma Marco Aurélio Greco, essa espécie tributária se submete a uma técnica de validação finalística ${ }^{58}$ (sendo o aspecto econômico um elemento secundário), seja porque a competência para instituir essa espécie de tributo é privativa da União, ressalvada a dos Estados e Municípios para instituírem as destinadas ao custeio de seu próprio sistema previdenciário (cf. art. $149^{59}$ ).

Não obstante, para as contribuições sociais de seguridade social do art. 195 da CF/88 - tais o PIS e a Cofins objeto do presente estudo ${ }^{60}$ - o legislador constituinte indicou as materialidades econômicas sobre as quais poderiam incidir.

57 Distinção essa aferida pelo fato gerador e base de cálculo, cf. art. 154, II, verbis: “Art. 154. A União poderá instituir: I - mediante lei complementar, impostos não previstos no artigo anterior, desde que sejam nãocumulativos e não tenham fato gerador ou base de cálculo próprios dos discriminados nesta Constituição; II - na iminência ou no caso de guerra externa, impostos extraordinários, compreendidos ou não em sua competência tributária, os quais serão suprimidos, gradativamente, cessadas as causas de sua criação”.

58 Por validação finalística entenda-se o fato de as contribuições atenderem a uma finalidade eleita pela CF/88, à qual se vincula o interesse de determinado grupo (validação mediata), consistindo o instrumento de atuação da União para tanto (validação imediata). Cf. GRECO, Marco Aurélio. Contribuições (uma figura “sui generis") cit., p. 139.

59 “Art. 149. Compete exclusivamente à União instituir contribuições sociais, de intervenção no domínio econômico e de interesse das categorias profissionais ou econômicas, como instrumento de sua atuação nas respectivas áreas, observado o disposto nos arts. 146, III, e 150, I e III, e sem prejuízo do previsto no art. 195 , § 6. ${ }^{\circ}$, relativamente às contribuições a que alude o dispositivo. § 1. ${ }^{\circ}$ Os Estados, o Distrito Federal e os Municípios instituirão contribuição, cobrada de seus servidores, para o custeio, em benefício destes, do regime previdenciário de que trata o art. 40, cuja alíquota não será inferior à da contribuição dos servidores titulares de cargos efetivos da União."

60 Doutrina registra que apesar de incidentes sobre a mesma materialidade econômica (faturamento, até a EC 20/98, e receita, depois da referida emenda), o fundamento constitucional do PIS e da Cofins é distinto, pois a primeira contribuição apoia-se no art. 239 da CF/88, que recepcionou a contribuição instituída pela LC 7/70, e a segunda, no art. 195, I, b. Cf. TOMÉ, Fabiana Del Padre. Natureza jurídica da "nãocumulatividade" da contribuição ao PIS/Pasep e da Cofins: conseqüências e aplicabilidade. In: PEIXOTO, Marcelo Magalhães; FISCHER. Octávio Campos (Coord.). PIS-Cofins: questões atuais e polêmicas. São Paulo: Quartier Latin, 2005. p. 539. Mas a jurisprudência do STF afirma, desde o julgamento da ADC 1/DF, Rel. Min. Moreira Alves, DJU 16.06.1995, que "a recepção constitucional do PIS pelo art. 239 da CF, [...] não deixa de qualificá-lo como 'contribuição social sobre o faturamento', à qual se referia, genericamente, o inciso I do art. 195 da CF, na redação anterior à EC 20/98”. 
Pode-se entender que, tendo previsto que a seguridade social seria financiada por toda a sociedade, de forma direta e indireta, o constituinte julgou conveniente definir, desde logo, as fontes de riqueza com as quais a Federação custearia as atividades relacionadas aos direitos à saúde, à previdência e à assistência social. ${ }^{61}$

Assim, entrevendo a necessidade de outras fontes de financiamento e, na expectativa de evitar a tributação excessiva a que se referia Tipke, ${ }^{62}$ o constituinte arrolou, no art. 195, ${ }^{63}$ as materialidades econômicas aptas a tanto, mas reservou ao legislador infraconstitucional competência residual para instituir outras fontes de custeio, desde que obedecidos os requisitos do art. 154, I. $^{64}$

\subsubsection{Proposta de classificação das contribuições sociais de seguridade social de acordo com os grupos de impostos do CTN}

Em alguns casos, as materialidades econômicas sobre as quais incidem as contribuições de seguridade social do art. 195 da CF/88 coincidem com os pressupostos de fato indicados nos arts. 153, 155 e 156 da CF para os impostos. ${ }^{65}$

61 “Art. 194. A seguridade social compreende um conjunto integrado de ações de iniciativa dos Poderes Públicos e da sociedade, destinadas a assegurar os direitos relativos à saúde, à previdência e à assistência social.”

62 Apud SCHOUERI, Estudos em homenagem a Brandão Machado cit.,p. 106.

63 “Art. 195. A seguridade social será financiada por toda a sociedade, de forma direta e indireta, nos termos da lei, mediante recursos provenientes dos orçamentos da União, dos Estados, do Distrito Federal e dos Municípios, e das seguintes contribuições sociais: I - do empregador, da empresa e da entidade a ela equiparada na forma da lei, incidentes sobre: a) a folha de salários e demais rendimentos do trabalho pagos ou creditados, a qualquer título, à pessoa física que lhe preste serviço, mesmo sem vínculo empregatício; b) a receita ou o faturamento; c) o lucro; II - do trabalhador e dos demais segurados da previdência social, não incidindo contribuição sobre aposentadoria e pensão concedidas pelo regime geral de previdência social de que trata o art. 201; III - sobre a receita de concursos de prognósticos. IV - do importador de bens ou serviços do exterior, ou de quem a lei a ele equiparar. [...].”

64 “Art. 154. A União poderá instituir: I - mediante lei complementar, impostos não previstos no artigo anterior, desde que sejam não-cumulativos e não tenham fato gerador ou base de cálculo próprios dos discriminados nesta Constituição.”

65 E nisso não reside nenhuma inconstitucionalidade, pois, para as contribuições, "a Constituição não adota a materialidade do fato gerador para atribuir competências. Seu critério é outro [...] na lei instituidora, o que deverá ser verificado é o atendimento à finalidade. Se, para fins de viabilização operacional da contribuição, for previsto fato gerador ou base de cálculo idênticos aos de impostos e se, nesta formulação, estiverem atendidos os requisitos de compatibilidade com a finalidade, a superposição em relação a fato gerador e base de cálculo de impostos ... poderá ser criticável por razões econômicas, por gerar distorções, em suma, por incomodar profundamente, mas nunca é demais repetir que 'nem tudo que incomoda é inconstitucional'”. GRECO, Marco Aurélio. Contribuições (uma figura “sui generis”) cit., p. 149. 
À vista disso, entendemos que as contribuições sociais de seguridade social podem ser agrupadas pelos mesmos critérios adotados pelo CTN para os impostos.

Por seguir parâmetros legais, ou seja, os critérios econômicos do CTN, essa classificação isenta-se de subjetivismos e tem algumas utilidades:

(i) atender à finalidade da classificação econômica dos impostos já indicada por Tipke (cf. item 1.2): impedir a tributação excessiva, cuja relevância e atualidade decorrem não apenas do fato de o constituinte de 1988 ter concedido à União competência residual para criar novas contribuições de seguridade social (mediante lei complementar e desde que sejam não-cumulativas ${ }^{66}$ e não incidam sobre base de cálculo e fato gerador iguais aos das contribuições já existentes), mas também do abuso na instituição de novas fontes de custeio para a seguridade social, sempre por meio de emendas constitucionais (v.g., a receita e a importação, do art. 195, I, b e do art. 195, IV, respectivamente), e não por leis complementares. Tudo para driblar a proibição à tributação excessiva, a não-cumulatividade preconizada pela conjugação dos arts. 154, I, e $195, \S 4 .{ }^{.67}$ e, de quebra, furtar-se à repartição de receitas com os demais entes da federação, devida quando são criados impostos residuais; e

(ii) auxiliar na interpretação da não-cumulatividade do PIS e da Cofins, pois essa forma de arrecadação sempre esteve associada ao IPI e ao ICMS, impostos que tributam a circulação de riquezas.

Não queremos dizer que o aspecto material do fato gerador e a base de cálculo sejam o critério de validade das contribuições. Já vimos, com Marco Aurélio Greco, que o critério de validade das contribuições é finalístico. Mas esse mesmo autor afirma que "a qualificação pela materialidade não exclui, nem compromete, a constitucionalidade de uma lei que tenha seu fundamento de validade aferido em razão de uma finalidade”. ${ }^{68}$ Daí entendermos possível

66 Sobre a distinção entre a não-cumulatividade do art. 154, I da CF/88 e a não-cumulatividade do IPI, do ICMS e do PIS e da Cofins discorreremos em item específico adiante.

67 “Art. 195. [...] § 4..$^{\circ}$ A lei poderá instituir outras fontes destinadas a garantir a manutenção ou expansão da seguridade social, obedecido o disposto no art. 154, I.”

68 Contribuições (uma figura “sui generis”) cit., p. 148. 
classificar as contribuições cuja materialidade esteja expressa na constituição de acordo com os grupos de impostos do CTN.

Seguindo essa classificação, as contribuições do art. 195, I, $a$, da CF/88 - incidentes sobre a folha de salários e demais rendimentos do trabalho, pagos ou creditados, a qualquer título à pessoa física que preste serviço a empregadores, a empresas e a entidades a eles equiparadas na forma da lei - seriam exemplos de contribuições do grupo "sobre o patrimônio e a renda”, porque, a teor do art. 43, I, do CTN, ${ }^{69}$ o fruto do trabalho é renda do indivíduo.

A contribuição incidente sobre o lucro (art. 195, I, b) - CSLL, também seria classificada nesse mesmo grupo, porque "renda para a pessoa jurídica é identificada pelo conceito de lucro"70, o qual é uma das formas pelas quais se manifesta o acréscimo patrimonial da pessoa jurídica. ${ }^{71}$

Como exemplos de contribuições sociais de seguridade social do grupo "sobre o comércio exterior”, teríamos o PIS-importação e a Cofins-importação (CF/88, art. 195, IV).

Voltando nossa atenção para o objeto do presente estudo, vejamos qual seria o enquadramento do PIS e da Cofins não-cumulativos.

\subsection{Fonte de riqueza tributada pelas contribuições PIS e Cofins não-cumulativos}

De acordo com as Leis 10.637/2002 e 10.833/2003, o fato gerador do PIS e da Cofins não-cumulativos é “o faturamento mensal, assim entendido o total das receitas auferidas pela pessoa jurídica, independentemente de sua denominação ou classificação contábil” (art. 1. ${ }^{\circ}$ ). $\mathrm{O} \S 1 .^{\circ}$ do art. $1 .^{\circ}$ de ambas as leis esclarece: “o total das receitas

69 “Art. 43. O imposto, de competência da União, sobre a renda e proventos de qualquer natureza tem como fato gerador a aquisição da disponibilidade econômica ou jurídica: I - de renda, assim entendido o produto do capital, do trabalho ou da combinação de ambos.”

70 MINATEL, José Antônio. Conteúdo do conceito de receita... cit., p. 122.

71 Cf. Idem, ibidem, p. 124: "resultado [...] se positivo, traduz acréscimo patrimonial que é verbalizado no conceito de lucro". 
compreende a receita bruta da venda de bens e serviços nas operações em conta própria ou alheia e todas as demais receitas auferidas pela pessoa jurídica”, ${ }^{72}$

Note-se a dicção legal: o fato gerador é o faturamento, equiparado à totalidade das receitas, a qual compreende não só a receita bruta da venda de bens e serviços, mas também todas as outras receitas auferidas pela pessoa jurídica.

Todavia, como ressaltaram Ataliba e Giardino em parecer clássico sobre a hipótese de incidência (fato gerador) do PIS instituído pela LC 7/70, há impropriedade em indicar o faturamento como fato gerador de qualquer tributo, pois “emitir faturas” é ato sem qualquer significação econômica. Para os referidos tributaristas, o faturamento "é mera decorrência de outro acontecimento - este, sim, economicamente importante - correspondente à realização de "operações ou atividades da qual esse faturamento decorre". 73

Na verdade, a expressão faturamento usada pela LC $7 / 70$ era metonímica: representava a contraprestação (receita) das operações das quais decorre o faturamento. Em outras palavras, as operações não são o acontecimento de que decorre a significação econômica do fato gerador do PIS e da Cofins; a receita proveniente das referidas operações, traduzindo a contraprestação pela sua realização, denotam a significação econômica necessária à instituição de tributos.

Para saber em que medida a definição ampla de faturamento constante das Leis 10.637/2002 e 10.833/2003, equiparada à totalidade das receitas da pessoa jurídica, revela a fonte de riqueza tributada por essas contribuições e para enquadrar o PIS e a Cofins na classificação ora proposta, é necessário analisar a evolução da legislação e da jurisprudência a respeito.

\subsubsection{Síntese da evolução legislativa e jurisprudencial do PIS e da Cofins}

A contribuição para o PIS, instituída pela LC 7/70 e recepcionada pelo art. 239 da $\mathrm{CF} / 88$, era cobrada de forma diferenciada, de acordo com a atividade exercida pela pessoa

\footnotetext{
72 Cf. art. $1 .^{\circ}$ e $\S 1 .^{\circ}$ das Leis $10.637 / 2002$ e $10.833 / 2003$.

73 PIS - Exclusão do ICM de sua base de cálculo cit., n. 35, p. 154 (destaque nosso).
} 
jurídica. ${ }^{74}$ As empresas que realizavam vendas mercantis contribuíam com duas parcelas: uma, formada a partir da dedução do IRPJ devido (ou como se devido fosse, no caso de empresas isentas) - o chamado "PIS dedução"; outra calculada sobre o faturamento, denominada "PIS recursos próprios", em contraposição à primeira parcela que, sendo deduzida do IRPJ devido, entendia-se formada por recursos que não pertenciam à empresa, mas à União, como parte de sua arrecadação tributária. As empresas ditas não mercantis (instituições financeiras, seguradoras e outras que não realizam vendas de mercadorias - v.g., as exclusivamente prestadoras de serviços) também contribuíam com duas parcelas: a primeira deduzida do IRPJ, tal e qual as empresas mercantis, e a segunda, também com recursos próprios, de valor idêntico ao da primeira, chamada por isso mesmo de "PIS repique". ${ }^{75}$

A legislação do Finsocial, instituído sob a égide da CF/67/69 pelo DL 1.940/82, também diferenciava as contribuições conforme a atividade da empresa. As empresas que fossem, simultaneamente, vendedoras de mercadorias e prestadoras de serviços contribuíam com base na receita bruta das vendas de mercadorias e da prestação de serviços; as instituições financeiras e entidades a ela equiparadas o faziam com base na receita operacional; as sociedades seguradoras e entidades equiparadas contribuíam com base nas

74 Os Decretos-leis 2.445/88 e 2.449/88 pretenderam alterar a base de cálculo da contribuição ao PIS, determinando sua incidência não mais sobre o faturamento, mas sobre a "receita operacional”, definida como o "somatório das receitas que dão origem ao lucro operacional, na forma da legislação do imposto de renda”. Mas o Plenário do STF declarou inconstitucionais os referidos Decretos-leis por vício formal como o PIS, sob a égide da CF/67/69 e após a EC 8/77, não poderia ser considerado tributo, não poderia ser regulado via decreto-lei. Esse entendimento se deu no julgamento do RE 148.754/RJ (julgamento em 24.06.1993, DJU 04.03.1994) e levou o Senado Federal a publicar, em 10.10.1995, a Resolução 49, que suspendeu a execução daqueles decretos restabelecendo-se, por consequência, a vigência da LC 7/70.

75 “Art. 3. ${ }^{\circ}$ O Fundo de Participação será constituído por duas parcelas: a) a primeira, mediante dedução do Imposto de Renda devido, na forma estabelecida no $\S 1$. $^{\circ}$ deste artigo, processando-se o seu recolhimento ao Fundo juntamente com o pagamento do Imposto de Renda; b) a segunda, com recursos próprios da empresa, calculados com base no faturamento, como segue: 1) no exercício de 1971, 0,15\%; 2) no exercício de 1972, 0,25\%; 3) no exercício de 1973, 0,40\%; 4) no exercício de 1974 e subseqüentes, 0,50\%. § 1 . $^{\circ}$ A dedução a que se refere a alínea a deste artigo será feita sem prejuízo do direito de utilização dos incentivos fiscais previstos na legislação em vigor e calculada com base no valor do Imposto de Renda devido, nas seguintes proporções: a) no exercício de 1971 - 2\%; b) no exercício de 1972 - 3\%; c) no exercício de 1973 e subseqüentes - 5\%. § 2. ${ }^{\circ}$ As instituições financeiras, sociedades seguradoras e outras empresas que não realizam operações de vendas de mercadorias participarão do Programa de Integração Social com uma contribuição ao Fundo de Participação de recursos próprios de valor idêntico do que for apurado na forma do parágrafo anterior. $\S 3 .^{\circ}$ As empresas a título de incentivos fiscais estejam isentas, ou venham a ser isentadas, do pagamento do Imposto de Renda, contribuirão para o Fundo de Participação, na base de cálculo como se aquele tributo fosse devido, obedecidas as percentagens previstas neste artigo. $\S 4 .^{\circ}$ As entidades de fins não lucrativos, que tenham empregados assim definidos pela legislação trabalhista, contribuirão para o Fundo na forma da lei.” 
suas receitas patrimoniais e operacionais; as empresas exclusivamente prestadoras de serviços o faziam com base no IRPJ devido ou como se devido fosse. ${ }^{76}$

A contribuição ao Finsocial do DL 1.940/82 foi recepcionada pelo art. 56 do ADCT $^{77}$ da CF/88, até que nova lei dispusesse sobre a matéria. Disse o STF, nos julgamentos dos RREE 150.755-1/PE ${ }^{78}$ e 150.764-1/PE, ${ }^{79}$ que sua recepção pela atual Constituição se deu como contribuição de seguridade social, apesar de, sob a sistemática da CF/67/69, tratar-se de verdadeiro imposto residual de competência da União.

Foi então publicada a Lei 7.738/89 que determinou que as empresas exclusivamente prestadoras de serviços calculassem a contribuição ao Finsocial sobre sua receita bruta. ${ }^{80} \mathrm{~A}$ constitucionalidade da eleição da receita bruta como base de cálculo do Finsocial foi questionada pelos contribuintes, para quem que o legislador havia extrapolado os limites do art. 195, I, da CF/88, o qual autorizara a instituição de contribuição de seguridade social sobre o faturamento, mas não sobre a receita bruta. No leading case sobre a matéria, o já mencionado RE 150.755/PE, o STF ditou interpretação conforme a Constituição e disse que as prestadoras de serviços deveriam contribuir para o Finsocial, calculando-o sobre sua receita bruta, assim entendida como o faturamento, entrevisto como o produto das operações de venda mercantil e da prestação de serviços à vista e a prazo. Ou seja, a expressão legal "receita bruta” só seria constitucional (como base de cálculo da contribuição ao Finsocial das

76 Em voto vencido no RE 150.755/PE (julgamento em 18.11.1992, DJU 20.08.1993, Rel. para o acórdão o Min. Sepúlveda Pertence) o Min. Carlos Velloso sintetiza as quatro incidências contempladas pelo Finsocial: “a) receita bruta das vendas de mercadorias e de mercadorias e serviços (DL 1.940/82, art. 1. ${ }^{\circ}$. $1^{\circ}, a$, com a redação do art. 22 do DL 2.397/87); b) rendas e receitas operacionais das instituições financeiras e entidades a elas equiparadas (DL 1.940/82), art. $1 .^{\circ}, \S 1 .^{\circ}, b$, com a redação do art. 22 do DL 2.397/87); c) receitas operacionais e patrimoniais das sociedades seguradoras e entidades a elas equiparadas (DL 1.940/82, art. $1 .^{\circ}$. $§ 1 .^{\circ}, c$, com a redação do art. 22 do DL 2.397/87); d) imposto de renda devido, ou como se devido fosse, pelas empresas exclusivamente prestadoras de serviços (DL 1940/82, art. 1. ${ }^{\circ}$. § 2..$^{\circ}$ )”.

77 “Art. 56. Até que a lei disponha sobre o art. 195, I, a arrecadação decorrente de, no mínimo, cinco dos seis décimos percentuais correspondentes à alíquota da contribuição de que trata o Decreto-lei 1.940, de 25 de maio de 1982, alterada pelo Decreto-Lei 2.049, de $1 .^{\circ}$ de agosto de 1983, pelo Decreto 91.236, de 8 de maio de 1985, e pela Lei 7.611, de 8 de julho de 1987, passa a integrar a receita da seguridade social, ressalvados, exclusivamente no exercício de 1988, os compromissos assumidos com programas e projetos em andamento.”

78 Julgamento em 18.11.1992, DJU 20.08.1993, Rel. para o acórdão o Min. Sepúlveda Pertence.

79 Julgamento em 16.12.1992, DJU 02.04.1993, Rel. para o acórdão o Min. Marco Aurélio.

80 “Art. 28. Observado o disposto no art. 195, § 6. ${ }^{\circ}$, da Constituição, as empresas públicas ou privadas, que realizam exclusivamente venda de serviços, calcularão a contribuição para o Finsocial à alíquota de meio por cento sobre a receita bruta.” Essa alíquota foi posteriormente aumentada pelas Leis 7.787/89, 7.894/89 e 8.147/90. 
prestadoras de serviços) se se enquadrasse no conceito de faturamento e, para isso, deveria ser entendida como receita da venda de mercadorias e da prestação de serviços, pois esse seria, precisamente, o conceito de faturamento incorporado da legislação infraconstitucional pela Constituição. ${ }^{81}$

Sobreveio a LC 70/91 que, em obediência ao art. 56 do ADCT, finalmente dispôs sobre a contribuição do art. 195, I, da CF/88, incidente sobre o faturamento. Essa lei equiparou formalmente, pela primeira vez, o faturamento “à receita bruta das vendas de mercadorias, de mercadorias e serviços e de serviço de qualquer natureza”. ${ }^{2}$ E o STF, novamente prestigiando a interpretação conforme a Constituição, reputou correta tal equiparação, com a ressalva, já feita anteriormente, de que não haveria discrepância entre os conceitos de “receita bruta” e “faturamento” se - e somente se - esse último fosse interpretado no sentido fiscal, correspondente ao produto de todas as vendas, e não apenas das vendas a prazo. É o que decorre do voto do Min. Moreira Alves, relator da ADC 1-1/DF: ${ }^{83}$

[...] assinale-se a ausência de incongruência do excogitado art. 2. ${ }^{\circ}$ da LC 70/91, com o disposto no art. 195, I, da CF/88, ao definir "faturamento" como "a receita bruta das vendas de mercadorias, de mercadorias e serviços e de serviço de qualquer natureza”.

De efeito, o conceito de "receita bruta” não discrepa do "faturamento", na acepção que este termo é utilizado para efeitos fiscais, seja, o que corresponde ao produto de todas as vendas, não havendo qualquer razão para que lhe seja restringida a compreensão, estreitando-o nos limites do significado que o termo possui em direito comercial, seja aquele que abrange tão-somente as vendas a prazo (art. 1. ${ }^{\circ}$ da Lei 187/68 (em que a emissão de uma "fatura" constitui formalidade indispensável ao saque da correspondente duplicata).

A coexistência de duas contribuições incidentes sobre a mesma materialidade econômica (faturamento) foi expressamente admitida pelo STF, por entender que, ao recepcionar o PIS nos termos da LC 7/70 (ou seja, incidente sobre o faturamento), a CF/88

81 ÁVILA, Humberto. Contribuição social sobre o faturamento. Cofins. Base de cálculo. Distinção entre receita e faturamento. Jurisprudência do Supremo Tribunal Federal. Revista Dialética de Direito Tributário, n. 107, p. 102 (parênteses nossos).

82 “Art. 2. ${ }^{\circ}$ A contribuição de que trata o artigo anterior será de dois por cento e incidirá sobre o faturamento mensal, assim considerado a receita bruta das vendas de mercadorias, de mercadorias e serviços e de serviço de qualquer natureza."

83 Julgamento em 1.‥12.1993, DJU 16.05.1995, Rel. Min. Moreira Alves. 
não exauriu a possibilidade de criação de outra contribuição sobre o faturamento. Fosse assim, não teria indicado essa materialidade como fonte de custeio da seguridade social, no art. 195, I. ${ }^{84}$

Mais recentemente, a Lei 9.718/98, editada antes da alteração promovida pela EC 20/98 no inciso I do art. 195 da CF/88, disciplinou em conjunto o PIS e a Cofins. Disse que o faturamento, para fins de incidência dessas contribuições, equiparava-se à receita bruta da empresa, assim entendida como "a totalidade das receitas auferidas pela pessoa jurídica, sendo irrelevantes o tipo de atividade por ela exercida e a classificação contábil adotada para as receitas” (art. 3. ${ }^{\circ}, \S 1 .^{{ }^{885}}$ ).

Ao apreciar a questão no julgamento do RE 346.084-6/PR, o STF reafirmou o entendimento de que a noção de faturamento contida no texto da $\mathrm{CF} / 88$ não comportava a amplitude pretendida pelo art. 3. ${ }^{\circ}$ da Lei 9.718/98, o qual, indo além da equiparação inicialmente posta pelo Dec. 1.940/82, não se limitou a dizer que aquele termo equiparava-se à receita bruta advinda das operações de venda de mercadorias e prestação de serviços); disse a nova lei (9.718/98) que o faturamento equivalia à receita bruta e que esta corresponderia ao total das receitas auferidas pela empresa. Esse último passo ultrapassou o limite de qualquer interpretação conforme a Constituição, como disse o Min. Marco Aurélio, relator para o acórdão:

tivesse o legislador parado nessa disciplina, aludindo a faturamento sem darlhe, no campo da ficção jurídica, conotação discrepante da consagrada por doutrina e jurisprudência, ter-se-ia solução idêntica à concernente à Lei 9.715/98. ${ }^{86}$ Tomar-se-ia o faturamento tal como veio a ser explicitado na Ação Declaratória de Constitucionalidade n. 1-1/DF, ou seja, a envolver o

84 Cf. voto do Min. Moreira Alves, na já referida ADC 1-1/DF, p. 125 do acórdão.

85 “Art. 2. ${ }^{\circ}$ As contribuições para o PIS/Pasep e a Cofins, devidas pelas pessoas jurídicas de direito privado, serão calculadas com base no seu faturamento, observadas a legislação vigente e as alterações introduzidas por esta Lei. Art. 3. ${ }^{\circ} \mathrm{O}$ faturamento a que se refere o artigo anterior corresponde à receita bruta da pessoa jurídica. $\S 1$. $^{\circ}$ Entende-se por receita bruta a totalidade das receitas auferidas pela pessoa jurídica, sendo irrelevantes o tipo de atividade por ela exercida e a classificação contábil adotada para as receitas.”

86 Na ADIn 1.417-0/DF, julgamento em 02.08.1999, DJU 23.03.2001, Rel. Min. Octávio Gallotti, o STF entendeu que, consoante a interpretação conforme a Constituição já referendada na ADC 1-1/DF, o PIS poderia incidir sobre o faturamento, considerado como a receita bruta "proveniente da venda de bens nas operações de conta própria, do preço dos serviços prestados e do resultado auferido nas operações de conta alheia” (art. 3. ${ }^{\circ}$ da Lei 9.715/98). Declarou inconstitucional apenas a parte final do art. 18 da referida lei, segundo o qual seus efeitos retroagiriam a $1^{\circ} .10 .1995$, por entender que afrontava a anterioridade nonagesimal das contribuições sociais. 
conceito de receita bruta das vendas de mercadorias, de mercadorias e serviços e de serviços. [...] Não fosse o $\S 1 .^{\circ}$ que se seguiu, ter-se-ia a observância da jurisprudência desta Corte, no que ficara explicitado, na Ação Declaratória de Constitucionalidade n. 1-1/DF, a sinonímia dos vocábulos "faturamento" e "receita bruta". Todavia, o $\S 1 .^{\circ}$ veio a definir esta última de forma toda própria [...]. O passo mostrou-se demasiadamente largo, olvidando-se, por completo, não só a Lei Fundamental como também a interpretação desta já proclamada pelo Supremo Tribunal Federal. Fez-se incluir no conceito de receita bruta todo e qualquer aporte contabilizado pela empresa, pouco importando a origem, em si, e a classificação que deva ser levada em conta sob o ângulo contábil. ${ }^{87}$

As Leis 10.637/2002 e 10.833/2003 ${ }^{88}$ mantiveram a tendência legislativa de indicar o faturamento como fato gerador das contribuições PIS e Cofins. Mas, em vez de equiparar o faturamento à receita bruta e esta à totalidade das receitas, referidas leis disseram que o faturamento equiparava-se à receita total da empresa e esclareceram que a receita total compreendia não só a receita bruta proveniente da compra e venda mercantil e da prestação de serviços (receitas provenientes do faturamento, como já dissera o STF), mas também todas as demais receitas da pessoa jurídica. Note-se: para as novas leis, o faturamento não mais equivale à receita bruta; equivale sim ao total das receitas, que compreende a receita bruta e todas as demais outras receitas da empresa. ${ }^{89}$

87 RE 346.084-6/PR, julgamento em 09.11.2005, DJU 1. ‥09.2006, Rel. para o acórdão Min. Marco Aurélio.

88 No que interessa, na Lei 10.637/2002, o art. 1. ${ }^{\circ}$ previu: “A contribuição para o PIS/Pasep tem como fato gerador o faturamento mensal, assim entendido o total das receitas auferidas pela pessoa jurídica, independentemente de sua denominação ou classificação contábil. § 1. Para efeito do disposto neste artigo, o total das receitas compreende a receita bruta da venda de bens e serviços nas operações em conta própria ou alheia e todas as demais receitas auferidas pela pessoa jurídica”. Na Lei 10.833/2003, o art. 10. ${ }^{\circ}$ estabeleceu: “A Contribuição para o Financiamento da Seguridade Social - Cofins, com a incidência nãocumulativa, tem como fato gerador o faturamento mensal, assim entendido o total das receitas auferidas pela pessoa jurídica, independentemente de sua denominação ou classificação contábil. § 1. . Para efeito do disposto neste artigo, o total das receitas compreende a receita bruta da venda de bens e serviços nas operações em conta própria ou alheia e todas as demais receitas auferidas pela pessoa jurídica”.

89 No mesmo sentido, Vanessa Canado (As regras-matrizes... cit., p. 132, nota 174, p. 135-136), ao tratar da equiparação entre receita bruta (receita total) e faturamento da Lei 9.718/98 (repetida pelas Leis 10.637/2002 e 10.833/2003, já sem o vício de inconstitucionalidade que acometia a primeira): “além de equiparar faturamento a receita bruta, atribuiu aquela lei [a autora refere-se à Lei 9.718/98], a esta última palavra ('receita bruta'), o significado de receita total. Isto é, não deveria entender-se faturamento somente como o produto das vendas de mercadorias ou prestações de serviços (definição que coincide com a definição de receita bruta), mas como resultado de todas as atividades das pessoas jurídicas que tenham como produto a receita. Alega-se que essa equiparação de conceitos passou a alcançar, além das receitas tipicamente operacionais das pessoas jurídicas (vendas de mercadorias e/ou prestações de serviços) - receita bruta, espécie de receita - outras receitas como as financeiras outras assim indicadas pelas espécies de registros contábeis”. 
A nosso ver, o legislador nem precisava ter feito tal equiparação (entre faturamento e receita total), pois as Leis 10.637/2002 e 10.833/2003 foram editadas após a EC 20/98, que autorizou a tributação tanto da receita como do faturamento (cf. inciso I do art. 195 da $\mathrm{CF} / 88^{90}$ ); bastava, portanto, ter dito que aquelas contribuições sociais incidiriam sobre a receita das pessoas jurídicas. Mas quis ser mais ousado, equiparando aquilo que a doutrina, a jurisprudência do STF e o próprio texto constitucional emendado já haviam distinguido. Ou talvez tenha preferido insistir na linguagem que adotara anteriormente, como teimando em contrariar a interpretação do STF conforme a Constituição, segundo a qual a equiparação formal entre receita bruta e faturamento não é suficiente para alargar, materialmente, o espectro de incidência das contribuições de seguridade social, pois o conceito de faturamento incorporado pela CF/88 não é tão amplo.

\subsubsection{Faturamento vs. receita vs. operações: materialidade econômica do PIS e da Cofins não-cumulativos}

Da evolução legislativa e jurisprudencial sintetizada no item anterior podemos extrair que faturamento e receita são materialidades econômicas distintas, relativamente às quais a CF/88 autorizou a instituição de contribuições de seguridade social ${ }^{91}$.

Apesar de não fazer parte do escopo de nosso trabalho investigar o conteúdo dos conceitos receita e faturamento, a distinção entre um e outro é relevante para que possamos determinar adequadamente a fonte de riqueza tributada pelas contribuições em estudo.

Entre os diversos autores que trataram do tema, ${ }^{92}$ tomaremos emprestada a análise de José Antônio Minatel sobre o significado do termo receita enquanto “conceito jurídicosubstancial” apto a ensejar a instituição de tributos. ${ }^{93}$

90 “Art. 195. A seguridade social será financiada por toda a sociedade, de forma direta e indireta, nos termos da lei, mediante recursos provenientes dos orçamentos da União, dos Estados, do Distrito Federal e dos Municípios, e das seguintes contribuições sociais: - do empregador, da empresa e da entidade a ela equiparada na forma da lei, incidentes sobre: [...] b) a receita ou o faturamento.”

91 É bem verdade que a receita (no sentido de receita total) abrange a receita proveniente do faturamento. Mas, exatamente por isso, são distintas. Tanto são distintas que a EC 20/98, literalmente emendando o soneto, inseriu a receita como uma nova realidade tributável pelas contribuições de seguridade social. A conjunção ou utilizada no art. 195, I, $b$, só pode ter o sentido de distinguir as duas materialidades. A nosso ver, dizer que o ou, nesse caso, revela que faturamento é sinônimo de receita (de modo que tanto faria instituir a contribuição sobre um ou outro) é ignorar toda a evolução jurisprudencial sobre a matéria. 
Em seu cuidadoso estudo, Minatel analisou as conotações que o termo receita pode ter para as diferentes linguagens (constitucional, societária, contábil, econômica, de finanças públicas e também para a lei tributária). Constatou que, em cada uma delas, o conceito de receita vem usualmente associado a diversos outros conceitos, deles se aproximando ou se afastando, conforme o contexto. Empreendendo aquilo que denominou de "busca do conceito de receita”, o autor dissecou as diferenças e semelhanças entre receita e faturamento; receita e ingresso; receita, renda e lucro; receita e ganho de capital; receita, capital e investimento; receita e movimentação financeira; e receita e indenização. Conseguiu, ao final, extrair as "notas determinantes do conceito de receita”, anunciando:

receita é qualificada pelo ingresso de recursos financeiros no patrimônio da pessoa jurídica, em caráter definitivo, proveniente dos negócios jurídicos que envolvam o exercício da atividade empresarial, que corresponda à contraprestação pela venda de mercadorias, pela prestação de serviços, assim como pela remuneração de investimentos ou pela cessão onerosa e temporária de bens e direitos a terceiros, aferido instantaneamente pela contrapartida que remunera cada um desses eventos. ${ }^{94}$

Esse é o conceito de receita que, de agora em diante, adotaremos sempre que nos referirmos à receita total, que é a materialidade econômica tributada pelo PIS e pela Cofins das Leis 10.637/2002 e 10.833/2003. Além contemplar o que foi consagrado pela jurisprudência, isto é, que receita é termo mais amplo que faturamento, pois engloba a contraprestação por diversas operações e negócios da empresa, e não só pelas vendas de mercadorias e serviços, o conceito elaborado pelo referido autor acrescenta dado importante:

92 Cf. ÁVILA, Humberto. Contribuição social sobre o faturamento... cit., p. 95; COELHO, Sacha Calmon Navarro; MANEIRA, Eduardo; SANTIAGO, Igor Mauler. Inconstitucionalidade da Lei 9.718/98, na parte em que alargou a base de cálculo da Cofins - uma abordagem de direito intertemporal. Revista Dialética de Direito Tributário, n. 73, p. 126; BORGES, José Souto Maior. As contribuições sociais (PIS/Cofins) e a jurisprudência do STF. Revista Dialética de Direito Tributário, n. 118, p. 76; BRITO, Edvaldo. Cofins e PIS/Pasep: conceito de faturamento e de receita bruta, II - CPMF: questionamentos jurídicos. Revista Dialética de Direito Tributário, n. 43, p. 33; OLIVEIRA, Ricardo Mariz de. O conceito de receita como hipótese das contribuições para a seguridade social (para efeitos da Cofins e da Contribuição ao PIS). Repertório IOB de Jurisprudência, n. 1, caderno 1, p. 20-43, 2001.

93 A expressão “conceito jurídico-substancial”, como revela Minatel (O conteúdo do conceito de receita ... cit., p. 105), é de Marco Aurélio Greco, utilizada para referir-se a "fatos qualificados juridicamente e dotados de materialidade que permite identificar realidade econômica reveladora de capacidade contributiva objetiva” (Cofins na Lei n. 9.718/98 - variações cambiais e regime de alíquota acrescida. Revista Dialética de Direito Tributário n. 50, p. 131).

94 Conteúdo do conceito de receita... cit., p. 146. 
só será receita aquela contraprestação que representar ingresso de recursos financeiros no patrimônio da pessoa jurídica em caráter definitivo.

Tomaremos emprestado também de José Antônio Minatel o conceito de faturamento, que "pode ser visto como receita, mas unicamente receita de vendas de mercadorias e de serviços, nada mais". 95

Dito isto podemos afirmar que o PIS e a Cofins, cuja legislação foi editada antes da EC 20/98 (Lei 9.718/98), alcançam as receitas decorrentes da prática de operações de fornecimento de mercadorias e de operações de prestação de serviços - ou seja, a receita bruta correspondente ao faturamento, de acordo com a interpretação conforme a Constituição ditada pelo STF. ${ }^{96}$ Já o PIS e a Cofins, cuja legislação foi editada após aquela EC (Leis 10.637/2002 e 10.833/2003), tributam a receita total, que compreende tanto a receita bruta originada das vendas de mercadorias e prestações de serviços (o faturamento) como também qualquer outra receita resultante de outras operações e negócios da pessoa jurídica. Nesse ponto, desnecessária qualquer interpretação conforme a constituição quanto aos termos faturamento e receita, pois a CF/88 emendada autorizou a tributação tanto de um como de outra.

Todavia, as operações que dão origem ao faturamento e à receita não são o fato gerador do PIS e Cofins, nem antes nem depois da EC 20/98.

Isso ficou esclarecido quando o STF julgou legítima a incidência do PIS e da Cofins sobre o faturamento de empresas distribuidoras de derivados de petróleo, mineradoras, distribuidoras de energia elétrica e executoras de serviços de telecomunicações. E o fez a despeito de a CF/88 estabelecer que nenhum outro imposto, ${ }^{97}$ além do ICMS, do Imposto de Renda e do Imposto de Importação, poderiam incidir sobre as operações relativas àqueles

95 Conteúdo do conceito de receita... cit., p. 113.

96 No mesmo sentido: WALD, Alexandre; NISHIOKA, Alexandre; MORAES, Allan. O aspecto temporal da hipótese de incidência das contribuições ao PIS e Cofins e as receitas não auferidas em virtude de inadimplemento. PIS-Cofins - questões atuais e polêmicas. São Paulo: Quartier Latin, 2005, p. 662. E também: FISCHER, Octávio Campos. A contribuição ao PIS. São Paulo: Dialética, 1999. p. 137.

97 Note-se que, ao reputar legítima a incidência do PIS e da Cofins sobre o faturamento daquelas empresas, o STF não se limitou ao argumento simplista de que a CF/88 vedava a instituição de outros impostos, mas não de outros tributos (como as referidas contribuições sociais). O acórdão pautou-se na distinção entre os pressupostos de fato. 
produtos e serviços (art. 155, § 3. ${ }^{\circ}$, da $\mathrm{CF} / 88^{98}$ ). Entendeu o STF que o faturamento constitui o "resultado global, abrangente, de inúmeras operações (venda de mercadoria, venda de serviços, venda de bens que não configuram mercadorias ou serviços, etc.)” e “distingue-se das operações que constituem hipótese de incidência do imposto único sobre combustíveis”. 99 Por isso, “o fato gerador do PIS não se identifica com o fato gerador do ICMS, tampouco a hipótese de incidência do PIS se constitui, conforme vimos, em operações relativas a minerais de forma específica, mas (no) faturamento, que é abrangente de inúmeras operações”. ${ }^{100}$

Doutrina autorizada extrema com maior clareza essa distinção, ao explicar que as operações tributadas pelo ICMS configuram pressuposto de fato bilateral, pois requerem a participação de mais de um agente; já o faturamento e a receita do PIS e da Cofins, apesar de serem frutos daquelas operações, revelam materialidade econômica unilateral, ligada exclusivamente ao contribuinte que os aufere. ${ }^{101}$ Além disso, o universo de elementos captáveis pelo PIS e Cofins não-cumulativos é mais abrangente que o referido pelo ICMS (e também pelo IPI), pois esses impostos dizem respeito ao processo de circulação de um produto (conotação física), ao passo que aquelas contribuições, tratando do processo de formação do faturamento e das receitas, levam em conta, além de elementos físicos, elementos financeiros relevantes para sua obtenção. ${ }^{102}$

98 “§ 3. À exceção dos impostos de que tratam o inciso II do caput deste artigo e o art. 153, I e II, nenhum outro imposto poderá incidir sobre operações relativas a energia elétrica, serviços de telecomunicações, derivados de petróleo, combustíveis e minerais do País.”

99 RE 230.377-7-RN (DJU 28.06.2002, Rel. Min. Carlos Velloso). A fundamentação do citado RE invoca o RE 144.971-DF, relatado também pelo Min. Carlos Velloso, onde é citado o julgamento da AMS 90.301SP, do extinto TFR (Rel. também o Min. Carlos Velloso, DJU de 01.03.1984), que tinha em mira a incidência do PIS sobre o faturamento das empresas que realizam operações com minerais, então sujeita ao imposto único sobre minerais, do art. 21, VIII, da CF/67/69. O trecho transcrito acima faz parte do acórdão da referida AMS e integra o voto do Min. Velloso nos RREE 230.337-7/DF e 144.971/DF.

100 A fundamentação do citado acórdão invoca o RE 144.971-DF, relatado também pelo Min. Carlos Velloso, do qual se extrai o trecho acima transcrito, ainda mais incisivo sobre a distinção entre faturamento e operações das quais ele resulta.

101 “[...] o fato gerador (do PIS e da Cofins) não são as operações com aquelas mercadorias, individualizadamente consideradas (pressuposto bilateral), mas a totalidade da receita delas decorrente (pressuposto unilateral, ligado exclusivamente à economia interna de cada contribuinte).” SANTIAGO, Igor Mauler; LOBATO, Valter. Análise dos arts. 10, XI, e 15, V, da Lei 10.833/2003 - Manutenção da Cofins e do PIS cumulativos para contratos de consórcio, de construção por empreitada e de fornecimento, a preço determinado, de bens e serviços, celebrados antes de 31 de outubro de 2003. PIS-Cofins: questões atuais e polêmicas. São Paulo: Quartier Latin, 2005, p. 578.

102 “[...] o referencial das regras legais que disciplinam a não-cumulatividade de PIS/Cofins são eventos que dizem respeito ao processo formativo que culmina com a receita, e não apenas eventos que digam respeito ao processo formativo de um determinado produto. Realmente, enquanto o processo formativo de um 


\subsubsection{PIS e Cofins cumulativos vs. PIS e Cofins não-cumulativos}

No item anterior, vimos que faturamento, receita e operações são materialidades distintas. Partindo-se da premissa de que o aspecto econômico do pressuposto de fato é critério apto a distinguir um tributo de outro (vide item 1.2 supra), poder-se-ia entender que o PIS e a Cofins incidentes sobre a receita correspondente ao faturamento (Lei 9.718/98) são uma espécie de contribuição e o PIS e a Cofins incidentes sobre a receita total (Leis $10.637 / 2002$ e 10.833/2003) são outra.

As Leis 10.637/2002 e 10.833/2003 parecem ter indicado que se trata de contribuições distintas ao dizer que determinadas pessoas jurídicas ${ }^{103}$ permanecem sujeitas ao PIS e à Cofins anteriores à sua instituição, não se lhes aplicando diversos os artigos das mencionadas leis que tratam do fato gerador e da base de cálculo ${ }^{104}$ - binômio eleito pela CF/88 para distinguir um imposto de outro e que, na perspectiva ora proposta, aplica-se também à diferenciação das diversas contribuições de seguridade social.

Nesse sentido, o fato gerador do PIS e da Cofins, cuja legislação foi editada antes da EC 20/98, é auferir receitas com operações de venda de mercadorias e serviços. Sua base de cálculo é a receita assim auferida, ou seja, a receita proveniente do faturamento, computadas as exclusões legais. Já o fato gerador do PIS e da Cofins, cuja legislação foi editada após aquela EC, é auferir receitas provenientes de operações que envolvam o exercício da

produto aponta no sentido de eventos de caráter físico a ele relativos, o processo formativo de uma receita aponta na direção de todos os elementos (físicos ou funcionais) relevantes para sua obtenção.” GRECO, Marco Aurélio. Não-cumulatividade no PIS e na Cofins cit., p. 108.

103 Na Lei 10.637/2002, o art. 8. ${ }^{\circ}$ previu: "Permanecem sujeitas às normas da legislação da contribuição para o PIS/Pasep, vigentes anteriormente a esta Lei, não se lhes aplicando as disposições dos arts. $1 .^{\circ}$ a 6 . $[$ [...]”. Na Lei 10.833/2002, o art. $10 .^{\circ}$ estabeleceu: “Art. 10. Permanecem sujeitas às normas da legislação da Cofins, vigentes anteriormente a esta Lei, não se lhes aplicando as disposições dos arts. $1 .^{\circ}$ a $8 .^{\circ}[$ [...]”. Em ambas as leis, o caput do art. $1 .^{\circ}$ trata do fato gerador e o seu $\S 2 .^{\circ}$ trata da base de cálculo.

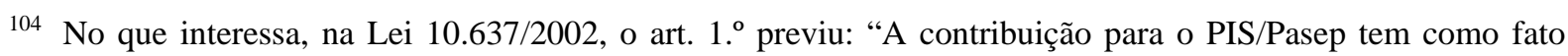
gerador o faturamento mensal, assim entendido o total das receitas auferidas pela pessoa jurídica, independentemente de sua denominação ou classificação contábil. § 1. Para efeito do disposto neste artigo, o total das receitas compreende a receita bruta da venda de bens e serviços nas operações em conta própria ou alheia e todas as demais receitas auferidas pela pessoa jurídica.”. E na Lei 10.833/2002, também no que pertine a essa observação, o art. $10 .^{\circ}$ estabeleceu: A Contribuição para o Financiamento da Seguridade Social - Cofins, com a incidência não-cumulativa, tem como fato gerador o faturamento mensal, assim entendido o total das receitas auferidas pela pessoa jurídica, independentemente de sua denominação ou classificação contábil. $\S 1 .^{\circ}$ Para efeito do disposto neste artigo, o total das receitas compreende a receita bruta da venda de bens e serviços nas operações em conta própria ou alheia e todas as demais receitas auferidas pela pessoa jurídica”. 


\section{atividade empresarial e correspondam não só à venda de mercadorias e prestações de} serviços, mas também à remuneração de investimentos e à cessão onerosa e temporária de bens e direitos. ${ }^{105}$ Sua base de cálculo são as receitas totais assim auferidas, diminuídas das exclusões indicadas nas respectivas legislações. Em ambos os casos, só será receita o ingresso que se incorporar em caráter definitivo ao patrimônio de quem a aufere. ${ }^{106}$

Ocorre que as Leis 10.637/2002 e 10.833/2003 excluem de seu âmbito de aplicação determinadas pessoas jurídicas e certas receitas, originadas de atividades específicas. A análise das receitas excluídas revela que são, invariavelmente, provenientes da venda de mercadorias ou da prestação de serviços, ou seja, de operações que dão origem ao faturamento $^{107}$ - o que, a princípio, confirmaria a conclusão de que existem duas

105 Cf. definição de José Antônio Minatel, Conteúdo do conceito de receita... cit., p. 146.

106 Idem, ibidem.

107 Confiram-se as receitas excluídas do âmbito das Leis de 2002 e 2003 (as explicações nos colchetes e os destaques em letras maiúsculas são nossos): Lei 10.637/2002, “Art. 8. ${ }^{\circ}$ Permanecem sujeitas às normas da legislação da contribuição para o PIS/Pasep, vigentes anteriormente a esta Lei, não se lhes aplicando as disposições dos arts. $1 .^{\circ}$ a $6{ }^{\circ}$ : [...] VII - as receitas decorrentes das operações: a) referidas no inciso IV do $\S$ 3..$^{\circ}$ do art. 1. ${ }^{\circ}$; (Vide Lei 11.727, de 2008) (Vigência) [VENDA de álcool para fins carburantes]; b) sujeitas à substituição tributária da contribuição para o PIS/Pasep; c) referidas no art. 5o da Lei no 9.716, de 26 de novembro de 1998; [que trata da COMPRA e VENDA de veículos automotores usados e do recebimento de outros veículos como parte do preço de venda]; VIII - as receitas decorrentes de prestação de SERVIÇOS de telecomunicações; IX - (Vetado) X - as sociedades cooperativas; (Incluído pela Lei 10.684, de 30.5.2003) XI - as receitas decorrentes de prestação de serviços das empresas jornalísticas e de radiodifusão sonora e de sons e imagens. (Incluído pela Lei 10.684, de 30.5.2003). Lei 10.833/2003, art. 10. "Permanecem sujeitas às normas da legislação da Cofins, vigentes anteriormente a esta Lei, não se lhes aplicando as disposições dos arts. $1 .^{\circ}$ a $8 .^{\circ}:$ [...] VII - as receitas decorrentes das operações: a) referidas no inciso IV do $\S 3 .^{\circ}$ do art. 1. ${ }^{\circ}$; (Vide Lei 11.727, de 2008) (Vigência) [VENDA de álcool para fins carburantes]; b) sujeitas à substituição tributária da Cofins; c) referidas no art. 5. ${ }^{\circ}$ da Lei 9.716, de 26 de novembro de 1998 [este artigo trata da COMPRA e VENDA de veículos automotores usados e do recebimento de outros veículos como parte do preço de venda]; VIII - as receitas decorrentes de prestação de SERVIÇOS de telecomunicações; IX - as receitas decorrentes de VENDA de jornais e periódicos e de prestação de SERVIÇOS das empresas jornalísticas e de radiodifusão sonora e de sons e imagens; (Redação dada pela Lei 10.865, de 2004); X - as receitas submetidas ao regime especial de tributação previsto no art. 47 da Lei no 10.637, de 30 de dezembro de 2002 [referida lei tratou do Mercado Atacadista de Energia Elétrica - MAE, cujo objeto era viabilizar as transações de COMPRA E VENDA de energia elétrica nos sistemas interligados]; XI - as receitas relativas a contratos firmados anteriormente a 31 de outubro de 2003: a) com prazo superior a 1 (um) ano, de administradoras de planos de consórcios de bens móveis e imóveis, regularmente autorizadas a funcionar pelo Banco Central [prestadoras de SERVIÇOS]; b) com prazo superior a 1 (um) ano, de construção por empreitada ou de fornecimento, a preço predeterminado, de bens ou serviços; [empreitada é prestação de SERVIÇO; fornecimento é VENDA]; c) de construção por empreitada ou de fornecimento, a preço predeterminado, de bens ou serviços contratados com pessoa jurídica de direito público, empresa pública, sociedade de economia mista ou suas subsidiárias, bem como os contratos posteriormente firmados decorrentes de propostas apresentadas, em processo licitatório, até aquela data; [empreitada é prestação de SERVIÇO; fornecimento é VENDA]; XII - as receitas decorrentes de prestação de SERVIÇOS de transporte coletivo rodoviário, metroviário, ferroviário e aquaviário de passageiros; XIII - as receitas decorrentes de SERVIÇOS: (Redação dada pela Lei 10.865, de 2004) a) prestados por hospital, pronto-socorro, clínica médica, odontológica, de fisioterapia e de fonoaudiologia, e 
contribuições: o PIS/Cofins incidentes sobre a totalidade das receitas, sujeitos à apuração nãocumulativa (por isso chamados PIS e Cofins não-cumulativos); e o PIS/Cofins incidentes sobre as receitas provenientes de operações de vendas de mercadorias e serviços (faturamento), as quais estão excluídas da não-cumulatividade (designados PIS e Cofins cumulativos).

Mas há casos em que o mesmo contribuinte aufere tanto receitas sujeitas à apuração cumulativa como receitas sujeitas à apuração não-cumulativa - o que infirma o raciocínio de que a amplitude da receita é que definiria a espécie de contribuição, à qual estaria submetido cada contribuinte.

Nas hipóteses em que a pessoa jurídica aufere apenas receitas excepcionadas da nãocumulatividade pelas referidas leis, pode-se entender que a remissão feita pelo art. $8 .^{\circ}$ da Lei 10.637/2002 e 10 da Lei 10.833/2003 aos arts. $1 .^{\circ}$ a $8 .^{\circ}$ refere-se apenas à forma de apuração das contribuições. Ou seja, essa remissão não significaria que existem duas espécies de

laboratório de anatomia patológica, citológica ou de análises clínicas; e (Incluído pela Lei 10.865, de 2004); b) de diálise, raios $\mathrm{X}$, radiodiagnóstico e radioterapia, quimioterapia e de banco de sangue; (Incluído pela Lei 10.865, de 2004) [todos SERVIÇOS]; XIV - as receitas decorrentes de prestação de SERVIÇOS de educação infantil, ensinos fundamental e médio e educação superior; XV - as receitas decorrentes de VENDAS de mercadorias realizadas pelas pessoas jurídicas referidas no art. 15 do Decreto-Lei no 1.455, de 7 de abril de 1976; (Incluído pela Lei 10.865, de 2004); XVI - as receitas decorrentes de prestação de SERVIÇO de transporte coletivo de passageiros, efetuado por empresas regulares de linhas aéreas domésticas, e as decorrentes da prestação de serviço de transporte de pessoas por empresas de táxi aéreo; (Incluído pela Lei 10.865, de 2004); XVII - as receitas auferidas por pessoas jurídicas, decorrentes da edição de periódicos e de informações neles contidas, que sejam relativas aos assinantes dos serviços públicos de telefonia; (Incluído pela Lei 10.865, de 2004) [SERVIÇOS]; XVIII - as receitas decorrentes de prestação de SERVIÇOS com aeronaves de uso agrícola inscritas no Registro Aeronáutico Brasileiro (RAB); (Incluído pela Lei 10.865, de 2004); XIX - as receitas decorrentes de prestação de SERVIÇOS das empresas de call center, telemarketing, telecobrança e de teleatendimento em geral; (Incluído pela Lei 10.865, de 2004); XX - as receitas decorrentes da execução por administração, empreitada ou subempreitada de obras de construção civil, até 31 de dezembro de 2008; (Redação dada pela Lei 11.434, de 2006) [SERVIÇOS]; XXI - as receitas auferidas por parques temáticos, e as decorrentes de serviços de hotelaria e de organização de feiras e eventos, conforme definido em ato conjunto dos Ministérios da Fazenda e do Turismo. (Incluído pela Lei 10.865, de 2004) [SERVIÇOS e VENDA]; XXII - as receitas decorrentes da prestação de SERVIÇOS postais e telegráficos prestados pela Empresa Brasileira de Correios e Telégrafos; (Incluído pela Lei 10.925, de 2004) (Vide Lei 10.925, de 2004); XXIII - as receitas decorrentes de prestação de SERVIÇOS públicos de concessionárias operadoras de rodovias; (Incluído pela Lei 10.925, de 2004); XXIV - as receitas decorrentes da prestação de SERVIÇOS das agências de viagem e de viagens e turismo. (Incluído pela Lei 10.925, de 2004); XXV - as receitas auferidas por empresas de SERVIÇOS de informática, decorrentes das atividades de desenvolvimento de software e o seu licenciamento ou cessão de direito de uso, bem como de análise, programação, instalação, configuração, assessoria, consultoria, suporte técnico e manutenção ou atualização de software, compreendidas ainda como softwares as páginas eletrônicas. (Incluído pela Lei 11.051, de 2004); XXVI - as receitas relativas às atividades de REVENDA de imóveis, desmembramento ou loteamento de terrenos, incorporação imobiliária e construção de prédio destinado à venda, quando decorrentes de contratos de longo prazo firmados antes de 31 de outubro de 2003; (Incluído dada pela Lei 11.196, de 2005).” 
contribuições, mas sim, que às contribuições PIS e Cofins recolhidas pelas pessoas jurídicas ali indicadas não se aplica a não-cumulatividade; as contribuições são cumulativas.

Mas que dizer da outra hipótese, em que o mesmo contribuinte aufere dois tipos de receitas, uma parte sujeita à apuração cumulativa e outra parte sujeita à apuração nãocumulativa: seria ele contribuinte de ambas as contribuições ou somente da contribuição incidente sobre a receita total, já que essa grandeza engloba a receita proveniente do faturamento, ou seja, a receita das operações de venda de mercadorias e prestação de serviços?

Nesse ponto, saltam aos olhos outras indagações, que vinham latentes desde que afirmamos ser legítima a incidência de duas contribuições (PIS e Cofins) sobre a mesma materialidade: o PIS e a Cofins são a mesma contribuição? Ou são contribuições diferentes, sendo determinantes para distingui-los suas destinações distintas: o PIS direcionado a custear programas de desenvolvimento econômico do BNDES, o seguro-desemprego e o abono aos empregados que contribuam para a formação do fundo e ganhem até dois salários mínimos ${ }^{108}$ e a Cofins integrando genericamente o orçamento da seguridade social? Ou será que, como afirmava Geraldo Ataliba, ${ }^{109}$ todas as contribuições dos empregadores referidas no art. 195, I, da CF/88 são, na verdade, apenas uma única contribuição, com base de cálculo resultante da combinação da folha, faturamento, lucro e, após a EC 20/98, também da receita?

108 “Art. 239. A arrecadação decorrente das contribuições para o Programa de Integração Social, criado pela Lei Complementar n. 7, de 7 de setembro de 1970, e para o Programa de Formação do Patrimônio do Servidor Público, criado pela Lei Complementar n. 8, de 3 de dezembro de 1970, passa, a partir da promulgação desta Constituição, a financiar, nos termos que a lei dispuser, o programa do seguro-desemprego e o abono de que trata o § 3..$^{\circ}$ deste artigo. § 1. ${ }^{\circ}$ Dos recursos mencionados no "caput" deste artigo, pelo menos quarenta por cento serão destinados a financiar programas de desenvolvimento econômico, através do Banco Nacional de Desenvolvimento Econômico e Social, com critérios de remuneração que lhes preservem o valor. [...] § 3. ${ }^{\circ}$ Aos empregados que percebam de empregadores que contribuem para o Programa de Integração Social ou para o Programa de Formação do Patrimônio do Servidor Público, até dois salários mínimos de remuneração mensal, é assegurado o pagamento de um salário mínimo anual, computado neste valor o rendimento das contas individuais, no caso daqueles que já participavam dos referidos programas, até a data da promulgação desta Constituição."

109 Finsocial. Contribuições sociais. Folha de S. Paulo, 21 jan. 1992, p. 2-2. Apud MELO, José Eduardo Soares de. Contribuições sociais no sistema tributário. 4. ed. rev., atual. e ampl. São Paulo: Malheiros, 2003, p. 319. 
Essas indagações remetem aos critérios distintivos das diversas espécies tributárias, que não é coisa singela. Juristas de escol ${ }^{110}$ abordaram o tema, escrevendo teorias que a autora do presente trabalho não tem a pretensão de refutar. A conclusão mais cediça é que o binômio constitucional "base de cálculo + fato gerador" (mais precisamente, o critério material da hipótese) é o mais adequado.

Eduardo Maneira, dissertando sobre as funções da base de cálculo, analisou com temperamento o entendimento manifestado por diversos autores de que essa grandeza, tendo o atributo de confirmar o aspecto ou critério material do fato gerador, seria apta para, em conjunto com o fato gerador, distinguir as espécies tributárias. Concluiu o professor mineiro que

a base de cálculo, quando muito, pode ser, ao lado do aspecto material da hipótese de incidência, critério escolhido para a identificação das espécies tributárias, que tem, no entanto, se revelado insuficiente para, no plano do direito positivo, distinguir todos os tributos. Se é possível, pela base de cálculo, desmascarar falsas taxas, ou falsas subespécies de impostos, o mesmo não se pode dizer em relação às contribuições sociais e aos empréstimos compulsórios que, no aspecto material da hipótese e na base de cálculo, se confundem com os impostos, diferenciando-se deles somente por suas características de tributos finalisticamente afetados. Concluindo: o aspecto material da hipótese de incidência se projeta na conseqüência da norma, onde se situa a base de cálculo. Esta, que deve ser uma medida do aspecto material, retorna à hipótese para confirmá-la ou infirmá-la. O que define a espécie tributária é o aspecto material da hipótese - e a teoria dos tributos vinculados e não vinculados é, sem dúvida, a melhor e a que mais segurança confere aos cidadãos-contribuintes - e, sendo o tributo instituído regular e logicamente, a hipótese de incidência será confirmada pela base de cálculo. No entanto, no caso de uma anomalia, isto é, de impertinência entre o aspecto material da hipótese e a base de cálculo, prevalece a base de cálculo para definir a espécie, com a conseqüência provável de fulminá-la e não de legitimá-la. ${ }^{111}$

Não desconhecemos a importância dessas indagações, mas, para os limites do presente estudo, que pretende contribuir para a interpretação da técnica de cobrança nãocumulativa do PIS e da Cofins implementada pelas Leis 10.637/2002 e 10.833/2003, bastam-

110 Alfredo Augusto Becker, Geraldo Ataliba, Paulo de Barros Carvalho, Sacha Calmon Navarro Coelho, entre outros.

111 MANEIRA, Eduardo. Base de cálculo presumida. 2002. Tese (Doutorado) - Belo Horizonte: UFMG, p. 135-137. 
nos os critérios postos pelo legislador constituinte como capazes de identificar a fonte de riqueza tributada por aquelas contribuições, ou seja, o fato gerador (aspecto material da hipótese) e a base de cálculo. ${ }^{112}$

Daí afirmarmos, no presente trabalho, que o PIS e a Cofins incidentes sobre a receita proveniente do faturamento (cumulativos) são contribuições distintas do PIS e da Cofins incidentes sobre a receita total (não-cumulativos). Ou seja, vislumbramos apenas duas contribuições (PIS/Cofins cumulativo e PIS/Cofins não-cumulativos); e não quatro contribuições (PIS cumulativo, Cofins cumulativa, PIS não-cumulativo e Cofins nãocumulativa).

Não obstante, no presente estudo nos referimos ao PIS e à Cofins separadamente, pois duas são as leis de regência e dois os nomes consagrados pela legislação e pela doutrina. De modo que, em vez de nos referirmos ao PIS/Cofins não-cumulativos, continuaremos a tratar da não-cumulatividade do PIS e da Cofins.

Vejamos, então, qual é sua fonte de riqueza tributável.

\subsubsection{PIS e Cofins não-cumulativos: contribuições de seguridade social que tributam a circulação de riquezas}

De tudo o que foi dito podemos concluir que, quando a EC 20/98 alterou o art. 195, I, $b$, da CF/88 e disse que a receita é materialidade econômica reveladora de capacidade contributiva apta a financiar a seguridade social, ampliou-se o âmbito da fonte de riqueza tributável por aquelas contribuições.

Se, antes, apenas a receita proveniente das operações de venda de mercadorias e serviços (o faturamento) poderia financiar a seguridade social, agora, prestam-se a tanto todos os ingressos definitivamente incorporados ao patrimônio das pessoas jurídicas em virtude de operações de venda de mercadorias, de prestação de serviços, de remuneração de investimentos e de cessão onerosa e temporária de bens e direitos a terceiros, que envolvam

112 Cf. Paulo de Barros Carvalho: "Finalizemos para dizer que, no direito brasileiro, o tipo tributário se acha integrado pela associação lógica e harmônica da hipótese de incidência e da base de cálculo. O binômio, adequadamente identificado, com revelar a natureza própria do tributo que investigamos, tem a excelsa virtude de nos proteger da linguagem imprecisa do legislador" (Curso de direito tributário cit., p. 29). 
sua atividade empresarial - ou seja, a receita total, conforme definição de José Antônio Minatel.

Essa ampliação do espectro de incidência das contribuições de seguridade social corresponde à evolução histórica há muito verificada na doutrina e consagrada pelo Código Civil de 2002 ao deslocar o foco da atividade econômica do comerciante para o empresário. $^{113}$

Nessa nova perspectiva, não é apenas a riqueza produzida com operações de venda de mercadorias e serviços que financiam a seguridade social; a riqueza advinda de outras operações empresariais também custeará as atividades voltadas a assegurar os direitos à saúde, à previdência e à assistência social. É dizer, a fonte tributável não é apenas a riqueza produzida nas etapas elementares de circulação, mas, sim, a riqueza produzida por determinados agentes econômicos e usufruída por outros, por meio das diversas modalidades de circulação econômica a que nos referimos no item 1.2.1, ou, nas palavras de José Antônio Minatel, as riquezas vinculadas ao exercício da atividade empresarial. ${ }^{114}$

Aqui vislumbramos a semelhança entre PIS e Cofins (cumulativos e nãocumulativos) e IPI e ICMS: embora recaiam sobre materialidades distintas - o faturamento, a receita total e as operações -, todos gravam aquilo que anteriormente designamos como circulação econômica. O PIS e a Cofins cumulativos, assim como o IPI e o ICMS, tributam a circulação econômica em sua acepção restrita, equivalente ao ciclo relativo à venda de mercadorias e serviços: os primeiros alcançam a receita proveniente desse ciclo, os últimos gravam os negócios e operações que materializam o referido ciclo econômico. Já o PIS e a Cofins não-cumulativos tributam a noção ampla de circulação econômica, onerando também as receitas provenientes de outros negócios e operações da pessoa jurídica.

113 Nossa afirmativa inspira-se em trecho de voto do Min. Cesar Peluso, proferido no já citado RE 346.0845/PA, que analisou o alargamento do conceito de faturamento pretendido pelo art. 3. ${ }^{\circ}$ da Lei 9.718/98: "Com a deslocação histórica do foco sobre a importância econômica e a tipificação dogmática da atividade negocial, do conceito de comerciante para o de empresa, justificava-se rever a noção de faturamento para que passasse a denotar agora as vendas realizadas pela empresa e relacionadas à sua 'atividade econômica organizada para a produção ou a circulação de bens ou de serviços', como consta hoje do art. 966 do Código Civil.”. CC/2002, art. 966: “Considera-se empresário quem exerce profissionalmente atividade econômica organizada para a produção ou a circulação de bens ou de serviços. Parágrafo único. Não se considera empresário quem exerce profissão intelectual, de natureza científica, literária ou artística, ainda com o concurso de auxiliares ou colaboradores, salvo se o exercício da profissão constituir elemento de empresa”.

114 Conteúdo do conceito de receita... cit., p. 313. 
Vale dizer, tanto PIS e Cofins (cumulativos e não-cumulativos) como IPI e ICMS tributam a circulação de riquezas. ${ }^{115}$ Desse entendimento comunga Ricardo Lobo Torres, ao afirmar que “[...] a proliferação das exóticas contribuições sociais não-cumulativas provocou inúmeros desajustes no sistema das incidências sobre a circulação de riquezas [...]”. 116

A receita tributada pelas contribuições PIS e Cofins - seja em sua acepção estrita, de ingresso patrimonial definitivo resultante das operações de venda de mercadorias e prestação de serviços (o faturamento), seja na concepção ampla, de ingresso patrimonial definitivo recebido em contraprestação de operações vinculadas também a outras atividades empresariais (a receita total) - equivale à riqueza produzida por determinado agente econômico: a pessoa jurídica que a aufere. Constitui riqueza produzida no ciclo de operações que promovem o giro da economia - riqueza produzida e oportunamente lançada ao consumo - e que, portanto, integra a fonte de riqueza tributável tradicionalmente denominada circulação de riquezas.

Em síntese, no que interessa ao presente estudo, duas são as materialidades econômicas que ensejam a tributação por via das contribuições de seguridade social: o faturamento (equivalente à receita bruta das vendas de mercadorias e serviços) e a receita total. Mas a fonte tributável é a mesma: a circulação de riquezas.

2.2.4.1 PIS e Cofins não-cumulativos: contribuições de seguridade social "sobre a produção e a circulação"

Retomando a classificação do PIS e da Cofins não-cumulativos conforme os grupos do CTN, descartamos desde logo sua inclusão junto às contribuições incidentes sobre o “comércio exterior” porque a receita total, que é sua materialidade econômica, pode também advir de negócios praticados dentro das divisas do território nacional.

Também não se relacionam com o grupo de contribuições incidentes sobre “patrimônio e renda”, pois receita, renda e lucro (esse último, enquanto acréscimo

115 Tanto mais porque o art. 195, I, $a$, da CF/88 estabelece que a receita tributada pelas referidas contribuições de seguridade social é aquela produzida pelo empregador, pela empresa e pela entidade a ela equiparada, ou seja, pelos agentes que se organizam para produzir bens ou prestar serviços, promovendo o giro econômico.

116 É possível a criação do IVA no Brasil? cit., p. 27. 
patrimonial que representa renda da pessoa jurídica) são pressupostos de fato que traduzem parcelas distintas da realidade econômica, como cuidadosamente anotou José Antônio Minatel:

\begin{abstract}
Enquanto o conteúdo material que representa a receita pode ser aferido na concreção de cada negócio jurídico isolado (instantâneo), e corresponde ao ingresso pelo recebimento do valor que remunera esforço ou atividade no contexto das operações mercantis praticadas pelas pessoas jurídicas (vendas de mercadorias ou de serviços), ou remunera direitos temporariamente cedidos a terceiros (juros, royalties, dividendos, aluguel), o conteúdo material que identifica a renda das pessoas jurídicas - lucro - só pode ser extraído ao término de um determinado período de tempo (compassado, periódico), pelo necessário confronto de uma multiplicidade de eventos revelados por negócios jurídicos de conteúdos individuais antagônicos (receitas e custos). [...] Um último registro, nesse tópico, para afastar qualquer possibilidade de equiparar-se receita ao conteúdo material revelado pela expressão patrimônio, se aventada a possibilidade dessa aproximação. [...] Patrimônio é conceito que revela realidade estática, expressando a dimensão do conjunto de bens, direitos e obrigações de titularidade da pessoa física ou jurídica em momento determinado. Não se aproxima do conceito de receita que, ao contrário, se particulariza pela dinâmica das operações da entidade empresarial que, isoladamente, têm aptidão de expressar uma contraprestação que a revela. Na sua extensão, o patrimônio pode abranger o conceito de renda, no sentido de acréscimo de riqueza, como acontece com o lucro auferido que integra o patrimônio da pessoa jurídica. Todavia, ainda que seja certo que a receita pode contribuir positivamente para a sua formação, perde a sua identidade dentro da nova realidade identificada pelo conteúdo que revela o resultado e, por isso, com ele não se confunde. ${ }^{117}$
\end{abstract}

Tendo em vista que a receita "se particulariza pela dinâmica das operações da entidade empresarial” pelas quais se revela, ${ }^{118}$ então a materialidade econômica alcançada pelo PIS e pela Cofins não-cumulativos é um aspecto dinâmico da riqueza que é fruto das atividades empresariais (riqueza produzida), e não o aspecto estático (riqueza acumulada), a que equivalem o patrimônio e a renda. ${ }^{119}$

117 Conteúdo do conceito de receita... cit., p. 124-128 (destaques no original).

118 Idem, ibidem, p. 128.

119 Essa mesma linguagem econômica que emprega a palavra receita "para designar a remuneração bruta dos fatores de produção, quase sempre com o objetivo de imediato confronto com os custos necessários para obtê-la” (MINATEL, José Antônio. Conteúdo do conceito de receita... cit., p. 87.), levou respeitados autores 
Diante das conclusões dos itens anteriores, de que (i) o PIS e a Cofins nãocumulativos tributam a circulação de riquezas e de que, (ii) ao agrupar no mesmo título os impostos sobre a produção e a circulação, o CTN teve em mira a circulação econômica, que não se limita às operações de produção e distribuição de mercadorias e serviços, pois abrange a produção e a circulação de riquezas provenientes de diversas outras operações que promovem o giro da economia de um país, julgamos adequado concluir que o PIS e a Cofins não-cumulativos qualificam-se como contribuições de seguridade social incidentes sobre a produção e a circulação.

Vale dizer, existe, subjacente ao PIS e à Cofins, um ciclo econômico que viabiliza sejam essas contribuições arrecadadas por meio de sistemática não-cumulativa, a qual foi inicialmente concebida para os demais tributos incidentes sobre a produção e a circulação: no Brasil, o IPI e o ICMS.

Mas, teria a não-cumulatividade do PIS e da Cofins o mesmo significado da nãocumulatividade dos demais tributos incidentes sobre a circulação de riqueza?

A resposta a tal indagação demanda análise mais detalhada dos exemplos mais tradicionais de tributos sobre a circulação de riquezas, os tributos sobre vendas/consumo, em cujo âmbito foi concebida a não-cumulatividade.

\footnotetext{
a, confundindo o aspecto econômico com o jurídico, aproximar materialidades distintas, quais sejam, receita e renda. Nesse equívoco incorre Ricardo Mariz de Oliveira ao dizer que "é válido para perquirição do que seja receita o que se aplica à renda, até porque renda, quando existente, depende e deriva de uma receita” (OLIVEIRA, Ricardo Mariz de. O conceito de receita... cit., p. 31. Ainda que a aproximação seja válida em termos econômicos, entendemos que, no campo das definições jurídicas, a razão está com Antônio Minatel, que refuta a assertiva de Ricardo Mariz dizendo que receita identifica-se com ingresso, mas renda, com resultado, para cuja apuração é necessário confrontar despesas e custos. Ou seja, são distintos os pressupostos de fato dos tributos incidentes sobre a receita e os pressupostos de fato daqueles que recaem sobre a renda.
} 


\section{TRIBUTOS SOBRE VENDAS E CONSUMO}

\subsection{Preâmbulo}

\subsubsection{A translação econômica e a translação jurídica ${ }^{120}$}

Considere-se a premissa econômica de que o comportamento de compradores e vendedores no mercado conduz ao ponto de equilíbrio, assim entendido como aquele ponto no qual, praticando-se determinado preço (o preço de equilíbrio), tudo o que for ofertado será consumido.

Se for instituído um tributo a ser pago pelos vendedores, o custo de produção/venda aumentará. A continuar praticando o mesmo preço (o preço de equilíbrio inicial), o vendedor terá que diminuir a quantidade de bens e serviços ofertados. Em consequência, a curva de oferta, que demonstra graficamente a quantidade de bens e serviços oferecidos àquele preço de equilíbrio inicial, vai se alterar. Para não haver escassez no mercado, ou seja, para manter a situação ideal de equilíbrio, em que as quantidades ofertadas são inteiramente consumidas, o vendedor terá que aumentar o preço. Restabelece-se, com isso, o equilíbrio, mas a um preço maior do que o inicial.

Por outro lado, se, em vez de instituir um tributo a ser pago pelo vendedor, o governo instituir um tributo que recaia sobre o bem ou serviço a ser consumido, o preço de equilíbrio também será alterado, pois o consumidor terá que desembolsar quantia maior para comprar o mesmo bem ou serviço. Dispondo de menos recursos, o consumidor comprará menos e, por conseguinte, sobrarão mais bens e serviços no mercado. Para manter as vendas, o vendedor acabará baixando o preço dos bens e serviços ofertados. O equilíbrio será restabelecido, mas agora a um preço novo, menor que o inicial.

A conclusão é que, de uma forma ou de outra, no novo ponto de equilíbrio que se estabelecer após a instituição do tributo, vendedores e consumidores compartilham seu ônus.

120 Parágrafos elaborados com apoio em: TEIXEIRA, Alessandra Brandão Machado. A tributação sobre o consumo de bens e serviços cit., p. 50-60. 
Interferirá nesse compartilhamento a elasticidade da oferta ou da demanda. A demanda é considerada inelástica (e, em contrapartida, a oferta é considerada elástica) quando, mesmo havendo aumento do preço, um determinado bem ou serviço não deixar de ser adquirido, mantendo-se as compras num patamar muito próximo ao existente antes do aumento do preço. É o que ocorre com produtos e serviços essenciais e insubstituíveis exemplo clássico, o sal - que não deixarão de ser adquiridos em razão de um aumento no preço. A demanda é considerada elástica (e, por conseguinte, a oferta inelástica) quando as quantidades demandadas variarem muito em função do preço. É o que ocorre com serviços e bens não essenciais substituíveis, que deixam de ser consumidos quando há um aumento de preço.

A repercussão do tributo para o consumidor será mais fácil quando se tratar de bens de demanda inelástica (v.g., bens de primeira necessidade) e mais difícil naqueles cuja demanda seja elástica (v.g., bens voluptuários). Mas, em qualquer hipótese, dada a tendência de o mercado buscar sempre o preço de equilibro, o custo do imposto será partilhado entre vendedores e adquirentes/consumidores.

Essa breve incursão na economia justifica-se no âmbito do presente trabalho porque explica o fenômeno econômico da translação econômica, que é a transferência adiante do custo financeiro do tributo.

Sendo certo que todo tributo comporta a translação econômica, ${ }^{121}$ é de supor que o contribuinte repercutido seja sempre o consumidor final, que não tem como transferir o custo tributário $^{122}$ adiante porque está no elo final da cadeia econômica. Daí por que, em economia, tributos sobre vendas são equiparados a tributos sobre consumo.

121 Cf. COELHO, Sacha Calmon Navarro. Curso de direito tributário: (comentários à Constituição e ao Código tributário nacional, artigo por artigo). Rio de Janeiro: Forense, 2001. p. 710: “O erro está em afirmar que uns tributos comportam, e outros não a possibilidade de transferência.Todos comportam! Veja-se o IPTU, que muitos, com erro, acham que é imposto real (também não existe imposto real, todo imposto é pessoal). Não transfere o locador ao locatário, no contrato, o dever de pagá-lo? Até o imposto de renda é transferível. As empresas, na contabilidade dos custos, incluem-no nos preços, se não pelo total, ao menos parcialmente. O imposto de renda das pessoas físicas, até ele, em certas circunstâncias, é transferível. Veja-se: os médicos não cobram mais ou menos conforme esteja ou não o imposto incluso no preço da consulta?”.

122 Graça Wagner, citado pelo Min. José Delgado no julgamento do EREsp 168.469/SP (julgamento em 10.11.1999, DJU 17.12.1999), distingue entre o encargo financeiro do tributo (a translação jurídica) e o ônus econômico do tributo (a translação econômica). No presente estudo, usaremos os termos encargo / 
Coisa distinta é a translação jurídica, também denominada repercussão obrigatória.

No Brasil, a distinção entre a transferência jurídica e a transferência econômica do encargo tributário finca raízes na evolução legal e jurisprudencial sobre a repetição do indébito tributário e remete à distinção dos tributos entre diretos e indiretos.

Antes da edição do CTN, o STF editara a Súmula 71, segundo a qual ,“embora pago indevidamente, não cabe restituição de tributo indireto”. ${ }^{123}$ Partiu da premissa de que, se o contribuinte havia transferido o encargo financeiro do tributo a terceiro, então a restituição resultaria em seu enriquecimento sem causa. A ter que sancionar algum enriquecimento indevido, o STF preferiu preservar o Estado e considerou inviável a restituição, deixando nas mãos do governo os recursos resultantes dos tributos indevidos e inconstitucionais. Colhe-se dos precedentes dessa súmula, os quais tinham em mira a taxa de fomento de produção agrícola e industrial do Estado do Espírito Santo e o Imposto sobre Vendas e Consignações (IVC), que, para o STF, quando o custo econômico do tributo é transferido para o preço, quem arca com ele é o adquirente. Esse seria o tributo indireto, pois o contribuinte (sujeito passivo da obrigação tributária) não é quem suporta os custos financeiros do tributo. Contrario sensu, se o contribuinte arcar com tais encargos econômicos, o tributo será direto.

Por todos, José Souto Maior Borges ${ }^{124}$ esclarece:

A incidência econômica traduzida em termos jurídicos equivale ao fenômeno da percussão, isto é, ao impacto, à queda, ao peso, ao ônus da carga tributária sobre uma determinada pessoa. Diz-se, então, que essa pessoa é o contribuinte percutido. Para não suportar economicamente esse impacto da carga tributária, o contribuinte percutido pode transferi-la a terceiros. A esse fenômeno se denomina repercussão econômica do tributo [...] [que] "processa-se geralmente através de mecanismos de formação de preços, aos quais se incorpora a parcela correspondente ao valor do tributo nas etapas dos ciclos de produção, industrialização e comercialização de bens. A repercussão ou translação (shifting, dos ingleses, Ueberwalzung, dos alemães) é, assim, a transferência do ônus tributário do contribuinte de direito (de jure) para o contribuinte de fato (de facto). A incidência econômica do tributo localiza-se nesse estágio terminal: pelo deslocamento

ônus / custo, como sinônimos, representando sempre o valor do tributo repassado adiante e adotaremos os adjetivos jurídico ou econômico para indicar a que tipo de translação nos referimos.

123 Sessão Plenária de 13.12.1963.

124 Teoria geral da isenção tributária, 3. ed. São Paulo: Malheiros, 2001. p. 186-189. 
da carga fiscal, esta fixa-se em alguém que não mais a pode transladar - o contribuinte economicamente incidido. [...] Diz-se que a incidência econômica é direta quando recai sobre o contribuinte percutido, e indireta quando assenta sobre o contribuinte repercutido.

Em 1969, o STF editou a Súmula 456, segundo a qual "cabe a restituição do tributo pago indevidamente, quando reconhecido por decisão, que o contribuinte 'de jure' não recuperou do contribuinte ‘de facto’ o ‘quantum’ respectivo”. ${ }^{125}$ Apesar de alguns precedentes terem sido julgados depois de já editado o CTN, tratavam todos de situação ocorrida antes da vigência daquele código. Essa nova súmula, que teve origem em casos sobre o IVC, do Imposto de Consumo e sobre a já mencionada taxa do Estado do Espírito Santo, representou flexibilização do entendimento do STF, pois abriu espaço para a restituição quando houvesse prova de que o contribuinte havia arcado com o respectivo custo econômico, mesmo quando se tratasse de tributos indiretos.

Sobreveio então o CTN, cujo art. 166 autorizou a restituição daqueles tributos que, por sua natureza, comportassem a transferência do encargo financeiro adiante, ${ }^{126}$ mediante prova de que o contribuinte o havia suportado ou, não tendo arcado com ele, estivesse autorizado pelo terceiro, que o suportara, a pleitear a restituição.

Ao contrário da jurisprudência, a lei não abordou a questão em termos da distinção entre tributos diretos e indiretos - o que seria mesmo inútil, pois, como havia dito o Min. Aliomar Baleeiro, a matéria é tormentosa até para os financistas, que "ainda não conseguiram, depois de 200 anos de discussão, desde os fisiocratas do século XVIII, um critério seguro para distinguir o imposto direto do indireto". 127

Partindo da realidade de que todo tributo comporta translação econômica por meio de ajustes no preço, o legislador quis destacar, no art. 166 do CTN, aqueles cuja própria natureza enseja tal repercussão, disciplinando sua restituição de forma especial.

\footnotetext{
125 Sessão Plenária de 03.12.1969.

126 “Art. 166. A restituição de tributos que comportem, por sua natureza, transferência do respectivo encargo financeiro somente será feita a quem prove haver assumido o referido encargo, ou, no caso de tê-lo transferido a terceiro, estar por este expressamente autorizado a recebê-la.”

127 Baleeiro, apud Min. José Delgado no mesmo EREsp 168.469 supracitado.
} 
Editada a lei, a questão relevante deixou de ser a distinção entre tributos diretos e indiretos. Era preciso determinar quais tributos comportariam, por sua natureza, a repercussão econômica (e aqui cabe uma crítica ao texto legal: tratando-se de transferência ínsita à natureza do imposto, ela nada tem de econômica; é jurídica. De modo que o CTN teria sido mais feliz se tivesse tratado, desde logo, da transferência jurídica do encargo tributário).

Sobre esse tema se pronunciou o STJ, no julgamento do já mencionado EREsp 168.469/SP, ao considerar desnecessária a prova da não-repercussão da contribuição previdenciária (parte do empregador). Afirmou o Ministro Relator, José Delgado, que, se a natureza do tributo só pode ser conhecida por meio de critérios normativos e jurídicos, a transferência de que trata o CTN deve ser igualmente aferida por tais critérios. Se, de um lado, economicamente, o custo do tributo pode ser transferido adiante em qualquer caso, por outro, juridicamente, essa translação só se dá quando existir uma relação transacional subjacente à relação tributária que permita tal repasse. Adotando-se a lição de Marco Aurélio Greco, o STJ entendeu que tributo que por sua própria natureza permite a translação é aquele cujo pressuposto de fato envolva uma dualidade de sujeitos, traduzindo uma operação no âmbito da qual tal transferência possa ocorrer, ${ }^{128}$ ou seja, cujo pressuposto de fato seja bilateral.

\subsubsection{Translação jurídica vs. não-cumulatividade vs. tributação sobre o consumo}

Feita a distinção entre a translação econômica e a jurídica do tributo e, dado que no sistema tributário atualmente em vigor ${ }^{129}$ o consumo não é fato gerador de nenhum tributo, qual seria o critério para considerar um tributo juridicamente incidente sobre o consumo?

Ricardo Lobo Torres, ${ }^{130}$ citando Klaus Tipke, explica que, na Europa, é a repercussão obrigatória “que transforma o imposto sobre o valor acrescido em um tributo

128 GRECO, Marco Aurélio. Repetição de indébito. Caderno de Pesquisas Tributárias, n. 8, p. 282, São Paulo: Resenha Tributária, 1983: "É forçoso concluir que o art. 166 do CTN contempla hipóteses de tributos cujo fato gerador, pelas suas peculiaridades, vincula duas pessoas que nele encontram o elemento de aproximação”.

129 Alcides Jorge Costa lembra que nem mesmo o IVA europeu tem o consumo por fato gerador. As Diretrizes da Comunidade Européia sobre o IVA dispõem que aquele imposto deve ser proporcional ao preço e onerar o consumo, mas esse é um princípio, uma diretiva, e não seu fato gerador (ICM - Estrutura na Constituição e na lei complementar cit., p. 76-77).

130 A não-cumulatividade no PIS/Cofins. PIS-Cofins: questões atuais e polêmicas. São Paulo: Quartier Latin, 2005, p. 65 (citação de Tipke indicada como extraída de “Über Umsatzsteuer-Gerechtigkeit. Stu W (2): 106, 1992). Em sentido contrário, Rubens Gomes de Sousa, criticando o que designou de "falácia jurídico-formal 
sobre o consumo". O interessante é que o professor usa indistintamente a expressão repercussão obrigatória para se referir tanto à repercussão jurídica como à repercussão econômica. Ou seja, não faz a distinção empreendida pela doutrina e reconhecida pelo STJ entre os dois tipos de repercussão. Também não diz que a repercussão obrigatória (econômica ou jurídica) só existe quando o encargo é transferido ao consumidor. Quando define a repercussão obrigatória, Ricardo Lobo Torres menciona que é princípio segundo o qual “a carga econômica dos tributos deve repercutir sobre o contribuinte de fato”. ${ }^{131}$

Ausente a distinção entre a repercussão econômica e a jurídica, Ricardo Lobo Torres $^{132}$ diz que, nos tributos sobre o consumo, o repasse da carga tributária ao contribuinte de fato pode se manifestar tanto pela não-cumulatividade (para ele, um subprincípio do princípio da repercussão obrigatória) como pela incidência monofásica associada à manipulação de alíquotas - hipótese em que a imposição sobre o consumo só se caracteriza sob o aspecto econômico, por via do já mencionado ajuste de preços. Pelas mesmas razões, o mencionado autor diz que a repercussão obrigatória ${ }^{133}$ deve ser respeitada na substituição tributária. São suas palavras: “quando se trata de responsabilidade do próprio contribuinte de direito, em que ele aparece como solvens ou Träger, a repercussão legal tem sentido marcantemente econômica (sic)”.

Essas assertivas corroboram o que a doutrina especializada explica: o tributo só se considera juridicamente incidente sobre o consumo quando existir algum mecanismo jurídico de transferência integral e individualizada de seu ônus para o consumidor final. ${ }^{134}$ Sem tais

da repercussão específica do imposto sobre o consumidor”, assevera que mesmo nas hipóteses em que a lei imponha a repercussão obrigatória, a questão continuará regida pelas leis de mercado e que, "confrontado com uma imposição dessa ordem, o 'contribuinte legal', na impossibilidade de majorar o preço de venda em importância igual ao imposto, terá de reajustá-lo de modo a cumprir formalmente a lei e ao mesmo tempo continuar a vender o produto. Esse reajustamento terá forçosamente de fazer-se à custa dos dois elementos de que se compõe o preço, isto é, o valor de custo e o lucro. Esgotada a capacidade de compressão do primeiro, o reajustamento se refletirá sobre o segundo, com a conseqüência, já referida, da absorção do imposto pelo 'contribuinte legal' até o limite da redução da margem de lucro.” E conclui: “os impostos sobre transações tendem, portanto, a agravar o valor do patrimônio transacionado, ou a renda bruta do vendedor” (SOUSA, Rubens Gomes de. A tributação das vendas cit., p. 10-11).

131 A não-cumulatividade no PIS/Cofins cit., p. 58.

132 Idem, ibidem, p. 58.

133 A nosso ver, o autor se refere, nesse ponto, à repercussão econômica.

134 Antonio Berliri, a nosso ver, confunde a repercussão jurídica com a econômica ao afirmar que, sendo o IVA um imposto sobre o consumo, a obrigação principal só se verifica em operações entre um contribuinte e um consumidor final e que as obrigações de entregar determinada quantia ao erário público, verificáveis nas 
instrumentos, o repasse integral da carga tributária ao consumidor final faz-se de forma difusa, embora seja de supor que se realize, de um modo ou de outro. Seria impossível e resultaria em verdadeiro caos admitir que um contribuinte viesse a se ressarcir do tributo repassado por outro contribuinte, a não ser regulando detalhadamente o repasse (e o respectivo ressarcimento), inclusive quanto ao seu montante.

A não-cumulatividade é instrumento da repercussão jurídica. É mecanismo para evitar a cumulatividade tributária. ${ }^{135}$ Mas essa repercussão também pode ocorrer quando a lei determinar que o preço incorpore o valor do tributo, como lembra Hugo de Brito Machado ao tratar do antigo imposto sobre serviços de comunicações. ${ }^{136}$ Já a incidência monofásica e a substituição tributária, na linha do que explicou Lobo Torres, instrumentalizam a repercussão econômica.

De qualquer forma, só se estará diante de incidência sobre o consumo em termos jurídicos quando, existindo mecanismos legais de regulamentação do repasse e ressarcimento dos tributos recolhidos por terceiros, o consumidor da mercadoria for o único sujeito que, na cadeia de circulação da riqueza tributada, não tenha como se ressarcir do imposto incidente sobre suas aquisições; ou, na não-cumulatividade, não tenha direito ao crédito correspondente.

No Brasil, a não-cumulatividade se verifica no IPI e ICMS, que têm pressuposto de fato bilateral: como visto no Capítulo 1, incidem sobre as etapas elementares de circulação

operações intermediárias, isto é, nas operações entre contribuintes, são apenas obrigações acessórias; de modo que o fato gerador do IVA só ocorre realmente quando da entrega do bem a um consumidor final. (L’imposta sul valore aggiunto. Milão: Giuffrè, 1971. p. 218). No original: “[...] la struttura dell’i.v.a. impone di ravvisare il presupposto del tribute solo nella vendita da un assoggettato ad un non assoggettato e pertanto solo dal verificarsi il tale fato nasce l'obligazione tributaria. Dal che discende inevitabile la conseguenza che l'obbligazione nascente da una cessione di beni tra assoggettati, non potendo essere un'obbligazione tributaria in senso stretto ed avendo come soggetto attivo lo Statu è necesariamente un’obbligazione accesoria”. Alcides Jorge Costa (ICM - Estrutura na Constituição e na lei complementar cit., p. 77), lembrando que o consumo não é fato gerador do IVA, considera inaceitável a conclusão do autor italiano, que "resulta da aplicação de um dado econômico a um fato jurídico."

135 Daí a doutrina afirmar que os tributos tratados no art. 166 do CTN têm a sua translação determinada pelo legislador, que contam com ela para estruturar o sistema da não-cumulatividade: SANTIAGO, Igor Mauler. Código Tributário Nacional - Arts. 165 a 169. In: PEIXOTO, Marcelo Magalhães; LACOMBE, Rodrigo Santos Masset. Comentários ao Código Tributário Nacional. 2. ed. rev. e ampl. São Paulo: MP, 2008. p. 1229-1267.

136 Em citação feita pelo Min. José Delgado no já citado EREsp 168.469, sobre a contribuição previdenciária, parte do empregador. 
econômica: a industrialização e a distribuição; portanto, têm como elemento essencial duas pessoas, a que faz circular o bem e a que o recebe - donde a bilateralidade.

A translação do IPI e do ICMS ocorre por meio da não-cumulatividade, que impulsiona o encargo jurídico do tributo adiante. Sua prova se faz por meio de destaque, na nota fiscal, do valor do imposto trasladado ao adquirente da mercadoria. Por isso que, mesmo incidindo sobre os consumos intermediários (aquisições de insumos), são considerados incidentes sobre o consumo: o destaque dos respectivos valores na nota fiscal e a nãocumulatividade são os instrumentos legais que asseguram a repercussão jurídica daquelas incidências. ${ }^{137}$

É dizer, o legislador constituinte, ao outorgar competência tributária para que União e Estados tributassem, respectivamente, a industrialização e as operações de circulação de mercadorias e produtos (e alguns serviços, no caso do ICMS), estabelecendo que tais tributos deveriam ser cobrados de forma não-cumulativa, prescreveu a transferência jurídica adiante dos respectivos encargos, optando, portanto, por tributar o consumo (inclusive o consumo intermediário) como manifestação de capacidade contributiva. ${ }^{138}$

Nas palavras de Misabel Derzi e Igor Santiago, o ICMS, o IPI e o IVA

oneram o consumo final e a formação bruta do capital fixo das famílias; oneram ainda os consumos intermediários e a formação bruta do capital fixo das administrações públicas no mundo inteiro. Quando isso não ocorre, ou seja, quando passa(m) a ser suportados(s) pelo setor produtivo, pelas empresas, os estudiosos e técnicos apontam-lhe(s) desvios, que prejudicam a capacidade de investimento e o desenvolvimento [...]. ${ }^{139}$

137 O IPI só repercutirá juridicamente até o consumidor final se o fabricante realizar vendas diretas, sem intermediação de atacadistas ou varejistas. Havendo intermediários, a repercussão do IPI até o consumidor final será econômica. Não obstante, o IPI também é considerado um tributo sobre o consumo, porque, como explicado, incide sobre os consumos intermediários, tais as aquisições de insumos.

138 DERZI, Misabel de Abreu Machado; COÊLHO, Sacha Calmon Navarro. O princípio da nãocumulatividade. Pesquisas tributárias nova série - n. 10. São Paulo: Centro de Extensão Universitária/Revista dos Tribunais [s.d.]. p. 109: “[...] tanto o ICMS quanto o IPI não são impostos que devam ser suportados, economicamente, pelo contribuinte de direito (o comerciante ou industrial). São, a rigor, impostos sobre o consumo, não devendo onerar a produção ou o comércio, como alerta Klaus Tipke”.

139 A harmonização dos IVAs do Brasil para o desenvolvimento produtivo. In: PEIXOTO, Marcelo Magalhães; FISCHER, Octávio Campos (Coord.). IVA para o Brasil: contributos para a reforma da tributação do consumo. Belo Horizonte: Fórum, 2007, p. 539 e 542. No mesmo sentido: COELHO, Sacha Calmon Navarro. O IVA brasileiro. In: PEIXOTO, Marcelo Magalhães; FISCHER, Octávio Campos (Coord.). IVA para o Brasil: contributos para a reforma da tributação do consumo. Belo Horizonte: Fórum, 2007, p. 579. 
IPI, ICMS e IVA requerem a existência de (ao menos) dois sujeitos, um que produz e outro que usufrui o bem. O consumo não é fato gerador, mas é inerente ao pressuposto de fato dos referidos tributos que incidem sobre operações de circulação de riqueza, $i$. $e$, sobre a riqueza produzida e lançada ao consumo. ${ }^{140}$

Mas, como veremos adiante, a não-cumulatividade presta-se também a outras finalidades, além de servir de instrumento de translação jurídica adiante do encargo tributário.

\subsubsection{Equiparação entre tributos sobre vendas e tributos sobre consumo}

John F. Due, professor de Economia da Universidade de Urbana, IL, nos Estados Unidos, que por mais de vinte anos estudou a tributação sobre vendas e seus efeitos sobre a economia, definiu os tributos sobre vendas como aqueles “incidentes sobre as vendas de todas ou de uma grande variedade de mercadorias, ou sobre elementos incidentais às vendas, tais as receitas delas provenientes”. 141

Adotando a definição, a doutrina refere-se, genericamente, a tributos sobre vendas “para designar um imposto (ou tributo) proporcional à receita de vendas (chiffre d'affaires) em conjunto, ou isoladamente de cada venda”. ${ }^{142}$

Por outro lado, como vimos em item anterior, a doutrina jurídica considera o tributo incidente sobre o consumo quando sua estrutura jurídica viabiliza a translação jurídica, que se opere por meio de determinados instrumentos. A mera translação econômica é irrelevante. Mesmo que seu fato gerador não seja o consumo, esse é o tributo sobre o consumo para o direito tributário.

Portanto, por rigor metodológico, as expressões tributos sobre vendas e tributos sobre consumo, designando coisas distintas, não poderiam ser intercambiáveis.

140 Misabel Derzi, chamando de fontes de riqueza tributável aquilo que enxergamos como pressupostos de fato, afirma: "no direito tributário [...] a lei é que imporá, criativamente, um novo tributo, o qual, repetitivamente, terá como base as fontes de riqueza já conhecidas: ou a circulação, ou a produção ou o consumo ou o capital” (Direito tributário, direito penal e tipo cit., p. 63).

141 Sales taxation. Londres: Routledge \& Kegan Paul, 1957. p. 3. No original: “a sales tax is a levy imposed upon the sales, or elements incidental to the sales, such as receipts from them, of all or a wide range of commodities [...]”.

142 COSTA, Alcides Jorge. ICM - Estrutura na Constituição e na lei complementar cit., p. 5, nota 8. 
Mas, como visto anteriormente, em economia, considera-se que tributos sobre vendas equivalem a tributos sobre o consumo. A equiparação decorre da tendência de equilíbrio do mercado, pois vendedores e compradores compartilham os impactos da tributação sobre o preço de bens e serviços. Em direito, a equiparação também é corrente, seja em virtude do caráter sinalagmático das operações de compra e venda - venda para determinado agente é compra (consumo, lato sensu) para outro -, seja porque o dispêndio dos adquirentes/consumidores representa a receita da venda para os vendedores. Contribui para o uso indistinto das duas expressões o fato de, no Brasil, o IPI e o ICMS - nossos tradicionais tributos sobre vendas - terem sido constitucionalmente alçados à categoria de tributos sobre o consumo, haja vista a previsão de que devem ser cobrados de forma não-cumulativa.

Como a não-cumulatividade surgiu no âmbito dos tributos sobre vendas/consumo, vejamos sua evolução histórica.

\subsection{Breve histórico da tributação sobre vendas/consumo}

J. Tavares Rocha, ${ }^{143}$ em excelente notícia histórica sobre o tema, relata que o primeiro imposto sobre vendas/consumo remonta à época dos Césares, quando era cobrado à alíquota de $1 \%$ sobre todas as coisas vendidas e por isso mesmo denominado Centesima Rerum Venalium. Abolido pelo imperador Calígula (anos 37 a 41 d.C), o imposto voltou à tona tempos depois, para ser novamente banido nos anos que antecederam a queda do Império Romano. A semente, porém, estava plantada e a ideia espalhou-se com o desenvolvimento do comércio.

Assim, durante a Idade Média, França e Espanha adotaram a tributação sobre vendas. Na França, a primeira experiência ocorreu em rápido episódio no reinado de Luiz XI (1461 a 1483), e, em seguida, na terceira república, com Napoleão III: o imposto era inicialmente cobrado sobre todos os negócios e, depois, apenas sobre determinadas mercadorias, como bebidas ou sal. ${ }^{144} \mathrm{Na}$ Espanha, instituído no século XIV, o tributo recebeu a denominação de alcabala, sendo repudiado pelos comerciantes, notadamente das colônias americanas.

\footnotetext{
143 Vendas e consignações. Rio de Janeiro: [s.n.], 1951. p. 5-7.

144 SOUSA, Rubens Gomes de. A tributação das vendas cit., p. 11-15.
} 
Nos séculos XVII e XIX, tal espécie de tributação foi relegada a um segundo plano, por ser considerada regressiva e, portanto, contrária aos princípios democráticos e à doutrina da capacidade contributiva, ${ }^{145}$ motes da Revolução Francesa. Mas, ainda que num plano secundário, preservaram-se, naquela época, diversas incidências sobre determinados produtos ou atividades, com feitio de impostos únicos e monofásicos, típicas representações do Estado Fiscal, intervencionista. ${ }^{146}$

Foi no período após a Primeira Guerra, em meados dos anos de 1920, que as legislações de diversos países, na Europa e nas Américas, dedicaram maior atenção aos tributos sobre vendas/consumo.

Em monografia sobre o tema, John F. Due ${ }^{147}$ ressaltou que a adoção desse tipo de tributo em diversos países se deu em virtude de sua excelente aptidão para, rapidamente, arrecadar receitas para os cofres públicos, tão ressentidos da primeira peleja mundial.

Sobre alcançar uma base ampla de contribuintes, permitindo, assim, a fixação de alíquotas menores (e sofrendo, portanto, menor oposição dos contribuintes), o repasse do encargo jurídico do tributo ao adquirente, inerente a esse tipo de tributação (daí serem também denominados tributos sobre o consumo), viabiliza a distribuição do ônus tributário de forma mais previsível que nos impostos sobre a renda e de modo menos evidente para os contribuintes (hidden effect of tax). ${ }^{148}$ Ainda em comparação ao imposto sobre a renda, os tributos sobre vendas/consumo são de apuração mais fácil. ${ }^{149}$ Além disso, nos Estados com organização federativa, onde tradicionalmente se atribui à União competência para tributar a

145 DUE, John F. Sales taxation cit., p. 2.

146 TÔRRES, Heleno Taveira. O IVA na experiência estrangeira e a tributação das exportações no direito brasileiro. IVA para o Brasil: contributos para a reforma da tributação do consumo. Belo Horizonte: Fórum, 2007, p. 70.

147 A essa aptidão para angariar vastas somas de dinheiro de forma rápida o autor atribui a ratio dos tributos sobre vendas: "Perhaps more than any other tax, the sales tax has been introduced as a measure designed to raise large sums of money quickly, under the pressure of financial emergency” (Sales taxation cit., p. 30).

148 Idem, ibidem, p. 58.

149 Paulo Bonilha anota como vantagem da tributação multifásica sobre vendas: “a definição jurídica e a base de cálculo são de fácil compreensão, ensejando-se boa aceitação do imposto e facilidade operacional que beneficia o contribuinte e a administração fiscal” (IPI e ICM fundamentos da técnica não-cumulativa. São Paulo: Resenha Tributária, 1979. p. 29). 
renda, os tributos sobre vendas configuram excelente fonte de renda autônoma para os membros da federação. ${ }^{150}$ Essas características fizeram com que a tributação sobre as vendas/consumo, inicialmente instituída em caráter temporário, com o intuito de apenas recompor as finanças públicas maltratadas pelas guerras, restasse definitivamente entrincheirada no cenário mundial após o fim do último (espera-se) combate mundial. ${ }^{151}$

Mas o tributo não restou isento de objeções, sendo a regressividade a mais saliente. Tendo em vista que esse tipo de tributo tem em mira o consumo, como exteriorização de capacidade contributiva, e, sendo o consumo inversamente proporcional à renda (num comparativo entre o consumo em função da renda, os mais ricos gastam, proporcionalmente, menos que os mais pobres), referidos tributos privilegiam as classes mais ricas. ${ }^{152}$ Por isso, durante muito tempo, foram tidos como típicos dos países subdesenvolvidos ${ }^{153}$ e acreditavase, até o fim do século XX, que a tributação sobre vendas/consumo cederia a outras formas de tributação sobre a renda e o patrimônio, os quais indicariam maior grau de desenvolvimento econômico de um país.

Na síntese de Maurin A. Falcão,

a lógica dos fluxos internacionais de investimentos e a transnacionalização das empresas reservaria um lugar de destaque para a tributação indireta. $\mathrm{Na}$ esteira das transformações impostas pela construção da ordem econômica internacional do pós-guerra, o questionamento dos efeitos do excesso de progressividade decorria de um novo quadro de competição global. A tendência decrescente da tributação sobre o patrimônio e a renda, em conseqüência, justamente, desta lógica econômica internacional, alterou profundamente o quadro tradicional dos sistemas tributários. A progressividade, tida anteriormente como o pilar de sustentação da justiça fiscal, passou a ser debatida devido aos seus efeitos intervencionistas nos sistemas tributários, em um mundo em mutação. A percepção ingênua de que a progressividade seria o único meio de assegurar a justiça fiscal foi

\footnotetext{
150 DUE, John F. Sales taxation cit., p. 40.

151 Idem, ibidem, p. 2.

152 Idem, p. 36.

153 Paulo Celso Bergstrom Bonilha, escrevendo em 1979 sobre a TVA francesa disse "que essa predominância da tributação indireta constitui exceção à regra, pois os países mais desenvolvidos auferem a maior parte de suas receitas tributárias dos impostos diretos” (IPI e ICM fundamentos da técnica não-cumulativa cit., p. 39). Todavia, sabemos que na Europa, a o IVA sempre teve extrema relevância arrecadatória.
} 
descartada tão logo as economias nacionais ganharam dimensões mundiais. Por isso, não restou aos estados qualquer caminho que não o alinhamento com o novo perfil dos sistemas tributários internacionais. A inserção nos circuitos globais tornou-se obsessão de um sem-número de países, o que decretou a remodelação dos sistemas tributários. A atenuação dos tributos incidentes sobre o patrimônio e a renda proveniente dos ganhos de capital passou a fazer parte da agenda tributária como condição para a inserção internacional. Esse panorama exigiu a busca de meios para compensar a perda de receitas tributárias. O caráter indolor da tributação sobre o consumo e a sua eficiência na correção da tributação sobre a renda as colocaram como a única via possível para enfrentar os novos tempos. ${ }^{154}$

Nos dias atuais, tanto em países subdesenvolvidos como em desenvolvidos, tributos sobre vendas/consumo coexistem lado a lado com tributos sobre a renda e o patrimônio, variando os métodos de apuração: a Europa adotou definitivamente a tributação plurifásica não-cumulativa e estabeleceu-a como condição para que qualquer país aspirante possa integrar a Comunidade Europeia (cf. Primeira e Segunda Diretivas); já os Estados Unidos permanecem com o imposto monofásico sobre vendas a varejo.

A importância e permanência da tributação sobre vendas/consumo até os dias atuais deve-se, fundamentalmente, à evolução na sua sistemática de arrecadação, resultado empírico da necessidade de afastar os inconvenientes econômicos da tributação plurifásica cumulativa.

\subsubsection{Os inconvenientes da tributação sobre vendas/consumo em cascata (regime plurifásico cumulativo)}

Em linhas gerais, um tributo é cumulativo quando as múltiplas incidências na cadeia produtiva ampliam, a cada etapa, a base tributável. Ocorre aí a chamada tributação em cascata, isto é, cobrança de tributo sobre tributo. ${ }^{155}$

${ }^{154}$ FALCÃO, Maurin Almeida. Da tributação cumulativa ao imposto sobre o valor agregado: o percurso notável da inovação tributária do Século XX. IVA para o Brasil: contributos para a reforma da tributação do consumo. Belo Horizonte: Fórum, 2007, p. 612-613.

155 Segundo Paulo B. Bonilha, a tributação plurifásica em cascata “diz-se plurifásica porque se pressupõe que o imposto seja pago por todos os que participam do ciclo de produção e comercialização do produto, cada vez que este seja objeto de uma transação. A incidência é cumulativa porque o imposto é devido em cada etapa sobre o preço do produto, independentemente de as operações anteriores já terem sido tributadas” (IPI $e$ ICM fundamentos da técnica não-cumulativa cit., p. 29). 
Tanto na Europa como no Brasil, a tributação sobre as vendas/consumo evoluiu da tributação plurifásica cumulativa para a tributação sobre o valor acrescido ${ }^{156}$ porque as desvantagens da tributação plurifásica cumulativa eram maiores que suas vantagens.

Como características positivas da tributação multifásica e em cascata, a história apontou a simplicidade de suas regras, que tornam a apuração do tributo menos complexa para os contribuintes e a fiscalização mais fácil para a administração tributária, além de ampliar a base tributável, o que enseja bons resultados arrecadatórios mesmo quando se aplica uma alíquota menos elevada. ${ }^{157}$

Essas mesmas virtudes, que fizeram da tributação plurifásica cumulativa sobre vendas/consumo a vedete dos governos nos anos de 1950 a 1970, tornaram-na algoz para o setor produtivo, dados seus efeitos perversos para a economia, a saber:

a. Prejuízos à concorrência: a tributação plurifásica cumulativa prejudica o consumo, os investimentos e a produção. Isso porque, quanto maior a cadeia de circulação da mercadoria, maior o número de incidências e, consequentemente, maior o custo tributário a ser repassado para o consumidor final. Como a carga tributária aumenta na proporção do ciclo produtivo, produtos de ciclo mais enxuto serão beneficiados em relação a produtos de ciclo mais longo, o que pode gerar iniquidades quando se tem em mira que certos bens supérfluos, como as joias, têm ciclo bem reduzido. Para evitar a superposição de incidências que majoram os custos de produção (e, consequentemente, o preço do produto final), os agentes econômicos buscam a integração vertical e passam a produzir por si mesmos as matérias-primas, os produtos intermediários, ou o material de embalagem que poderiam adquirir de terceiros; ou então incorporam em seus negócios as etapas de distribuição da mercadoria, evitando os atacadistas e os varejistas. Essa diminuição da concorrência traduz-se em aumento de preços para o consumidor final, que pode alterar seus hábitos de compra,

${ }^{156}$ Isso apesar de, no Brasil, IPI e ICMS não serem rigorosamente tributos sobre o valor acrescido, dado o alto resíduo de cumulatividade daqueles impostos.

157 BONILHA, Paulo B. IPI e ICM fundamentos da técnica não-cumulativa cit., p. 29. Hugo de Brito Machado destaca como "defeitos ou inconveniências da não-cumulatividade do ICMS brasileiro ... a) ônus sobre a produção; b) estímulo à intermediação; c) alíquotas elevadas; d) ensejo à fraude; e) complexidade; f) ensejo aos conflitos” (MACHADO, Hugo de Brito. Virtudes e defeitos da não-cumulatividade. In: MARTINS, Ives Gandra da Silva (Coord.) et al. Pesquisas tributárias - Nova Série - n. 10. O princípio da nãocumulatividade. São Paulo: Centro de Extensão Universitária/Revista dos Tribunais, 2004. p. 91. 
comprometendo, por conseguinte, a permanência de determinados agentes econômicos no mercado. À falta de especialização, dificulta-se a inserção de melhorias no processo produtivo. Além disso, a incidência indiscriminada dos impostos sobre vendas sobre todos os bens, incluindo os de produção, compromete a renovação do aparato industrial, adiando decisões sobre novos investimentos e altera o repasse do encargo tributário, pois o peso que os bens de produção representam no custo dos produtos finais não é uniforme;

b. prejuízos à balança comercial: na exportação, a mercadoria e os serviços estarão majorados pelos tributos incidentes sobre os insumos e bens de capital usados no processo produtivo, acumulados nas diversas etapas de circulação. Com isso, o produto exportado adentra o território estrangeiro com preço normalmente superior ao produto nacional (eis que majorado por tais custos) e não encontra condições de competir em pé de igualdade com a indústria local. Na outra mão, as mercadorias importadas são favorecidas, pois chegam ao país livres desse acúmulo de tributos e sofrem apenas a tributação da entrada, em clara desvantagem quanto à mercadoria produzida internamente, em cujo preço estarão embutidos os encargos dos impostos cumulados durante a produção;

c. prejuízos à administração do tributo: a fiscalização de todos os agentes econômicos envolvidos na circulação da mercadoria é tarefa pesada e cara. A perda de receita é grande, notadamente em países de maior dimensão territorial, que requerem maior amplitude da fiscalização. A precariedade dos registros dos comerciantes torna essa tarefa ainda mais difícil e resulta em perda de arrecadação e fraudes.

Na tentativa de contornar essas desvantagens da tributação cumulativa sobre vendas, surgiram as alternativas não-cumulativas: incidência em estágio singular (ou monofásica); e incidência plurifásica (ou de estágios múltiplos) sobre o valor agregado. É dizer: a cumulatividade verificada nos tributos sobre vendas conduziu à criação de mecanismos para eliminar seus efeitos nefastos.

A França foi pioneira na introdução de um mecanismo que contornava os malefícios da tributação sobre vendas/consumo em cascata. Seu exemplo espalhou-se pela Europa e chegou ao Brasil nos idos de 1960. 


\subsubsection{Os tributos sobre vendas/consumo na Europa}

3.2.2.1 Na França: do Imposto Geral sobre Vendas (L’Impôt sur le Chiffre d'Affaires) ao Imposto sobre o Valor Agregado (La Taxe sur la Valeur Ajoutée)

A tributação sobre vendas/consumo na França remonta à Primeira Guerra Mundial. Para financiar o déficit dela originado, foi instituída, em 1917, a taxe sur les paiements, incidente sobre os pagamentos civis e comerciais. ${ }^{158}$

Como seus resultados arrecadatórios mostravam-se insuficientes, aquele imposto foi substituído, em 1920, pela taxe sur le chiffre d'affaires, cobrada na produção, nas vendas em atacado e nas vendas ao consumidor, sem qualquer dedução - portanto, plurifásica e em cascata. Visando afastar essa superposição de impostos, devidos que eram em cada etapa do ciclo econômico do produto, foram instituídas incidências monofásicas sobre determinados produtos, cobradas na produção.

Em virtude da complexidade de administrar um sistema em que coexistiam impostos únicos/monofásicos com impostos plurifásicos e que, frequentemente, resultava na submissão de um mesmo contribuinte a dois regimes tributários distintos, a taxe sur les chiffres d'affaires foi substituída, em 1936, pela taxe à la production (ou taxe unique globale), cobrada dos fabricantes. Para evitar a incidência em cascata nas transações entre fabricantes (v.g., nas transações com matérias-primas e materiais secundários), instituiu-se uma sistemática de suspensão, na qual o imposto era pago apenas no final do ciclo de produção - o que resultou no retardamento do recebimento, pelo Estado, da respectiva receita de arrecadação, visto que era preciso aguardar o fim do ciclo produtivo para recebê-la.

Em 1948, foi suprimida a suspensão do imposto. Substituiu-a a autorização para que cada fabricante que pagasse a taxe à la production, compensasse, do imposto a recolher, o montante que tivesse incidido sobre as matérias-primas, materiais secundários e produtos

158 Esse item foi escrito a partir das anotações de Alcides Jorge Costa (ICM - Estrutura na Constituição e na lei complementar cit., p. 16-18), de Heleno Taveira Tôrres (O IVA na experiência estrangeira e a tributação das exportações no direito brasileiro. IVA para o Brasil cit., p. 71-73) e de Paulo Bergstrom Bonilha (IPI e ICM fundamentos da técnica não-cumulativa cit., p. 44-53). 
rapidamente consumidos na produção. Essa nova sistemática, que foi oportunamente chamada de imposto sobre pagamentos fracionados, introduzia a não-cumulatividade na Europa. ${ }^{159}$

Refinando o sistema e avaliando a experiência empírica da evolução da tributação sobre as vendas em seu país, o inspetor-geral de finanças da França, Maurice Lauré, apresentou proposta para a criação da Taxe sur la Valeur Ajoutée (TVA), que previa o abatimento relativo ao imposto pago na aquisição dos insumos físicos e financeiros de produção, incluindo, portanto, creditamento relativo aos equipamentos e bens do ativo. Em 10.04.1954, foi editada lei instituindo a TVA. Seguiram-se diversos aperfeiçoamentos, o último ocorrido em 1966 (com entrada em vigor em 1. ${ }^{\circ} .01 .1968$ ), estendendo-se o regime da TVA para todo o ciclo de produção e comercialização, incluindo o varejo. ${ }^{160}$

\subsubsection{Na União Europeia: da tributação plurifásica em cascata ao Imposto sobre o Valor Acrescido (IVA)}

Alcides Jorge Costa relata que, na tributação plurifásica em cascata, “o imposto incide sobre todas as vendas ocorridas no ciclo da produção e da comercialização", ${ }^{161}$ sem nenhuma dedução dos impostos incidentes nas etapas anteriores. Foi sob essa forma que a tributação sobre vendas se apresentou inicialmente na antiga Roma e na França e Espanha medievais. Modelo mais recente de tributação plurifásica cumulativa sobre vendas/consumo foi o alemão Umsatzsteuer, introduzido após a Primeira Guerra. Incidia sobre praticamente todas as transações, sobretaxando os bens supérfluos. ${ }^{162}$

Do detalhado estudo do direito comparado feito por John Due em sua obra Sales Taxation verifica-se que, em meados dos anos de 1650, vários países europeus adotavam a tributação multifásica em cascata, distinguindo-se suas legislações quanto a particularidades como a alíquota adotada e a base tributável. Em alguns países, os bens de primeira

\footnotetext{
159 Se bem que Alcides Jorge Costa alerta para o fato de que, quando ainda subsistia na França a sistemática de suspensão da taxe à la production, metade dos tributos incidentes sobre materiais de consumo rápido, utilizados na fabricação, podiam ser abatidos do imposto devido pelo fabricante final (ICM - Estrutura na Constituição e na lei complementar cit., p. 16).

160 COSTA, Alcides Jorge. ICM - Estrutura na Constituição e na lei complementar cit., p. 27.

161 Imposto de vendas e consignações: análise dos sistemas de arrecadação. Separata da Revista de Administração e Empresas da Fundação Getúlio Vargas, v. 2, n. 6, p. 56, São Paulo: FGV, [s.d.].

162 DUE, John F. Sales taxation cit., p. 51.
} 
necessidade estavam isentos (na Itália, pão e leite não se sujeitavam ao imposta generale sull'entrata) e, em outros, os serviços eram excluídos da tributação (caso da Bélgica, onde apenas alguns serviços, como o de transporte, eram taxados separadamente). ${ }^{163}$

Esse era o panorama da tributação sobre as vendas na Europa, quando da criação da Comunidade Econômica Europeia (CEE) pelo Tratado de Roma de 1957.

Para que os tributos não fossem óbices à integração almejada pelos países do bloco europeu, referido tratado previu, no seu art. 99, ${ }^{164}$ que os sistemas tributários dos paísesmembros seriam harmonizados, de forma que os impostos internos de cada país fossem neutros, não prejudicando a livre concorrência.

Assim, mirando-se na exitosa experiência francesa com a TVA e, a partir de estudos da comissão presidida por Fritz Neumark, que englobava tanto os tributos ditos diretos como os designados indiretos, o Conselho da CEE editou, em 1967, a Primeira e a Segunda Diretrizes, prevendo que todos os países integrantes da CEE deveriam adotar o IVA e ditando as estruturas e os métodos para sua implementação.

Passados os primeiros anos desde aquelas Diretivas, a CEE constatou que, para alcançar os objetivos de harmonização e neutralidade tributária previstos no Tratado de Roma, não era suficiente a adoção do IVA; era preciso que a base tributável em todos os países fosse a mesma. Assim, em 1977, foi editada a Sexta Diretiva, unificando as regras de incidência, de localização, as isenções, o cálculo do valor tributável e as deduções do IVA. "Posteriormente, atingiu-se uma estrutura comum de alíquotas, ou seja, definiram-se três faixas de alíquotas

\footnotetext{
163 Idem, ibidem, p. 92-111.

164 “Art. 99. O Conselho, deliberando por unanimidade, sob proposta da Comissão, e após consulta do Parlamento Europeu e do Comitè Económico e Social, adopta as disposições relacionadas com a harmonização das legislações relativas aos impostos sobre o volume de negócios, aos impostos espeicais de consumo e a outros impostos indirectos, na medida em que essa harmonização seja necessária para assegurar o estabelecimento e o funcionamento do mercado interno no prazo previsto no art. 7. o.a”, (Disponível em: <http://eur-lex.europa.eu/pt/treaties/dat/11992E/tif/JOC_1992_224_1_PT_0001.pdf>. Acesso em: 10 jan. 2009).
} 
(número de faixas máximo para cada país), com alíquotas oscilando entre um máximo e um mínimo dentro de cada faixa.»165

Finalmente, com a implementação da União Europeia pelo Tratado de Maastrich de 1992, que entrou em vigor a partir de 1.‥11.1993, foram abolidas as fronteiras físicas à circulação de mercadorias e as informações de controle tributário de todos os países integrantes passaram a ser compartilhadas com a implantação do sistema VAT Information Exchange System (VIES).

Atualmente, na Europa, coexistem diversas legislações sobre o IVA: cada paísmembro da União Europeia tem a sua própria legislação, mas todas harmônicas, pois baseadas nas Diretivas do Conselho. ${ }^{166}$

\subsubsection{Tributos sobre vendas/consumo no Brasil}

No Brasil, a tributação sobre vendas - tradicionalmente denominada tributação sobre o consumo - ocorre por intermédio do IPI e do ICMS, tributos de competência federal e estadual, respectivamente. ${ }^{167}$

\subsubsection{Do Imposto sobre Consumo ao Imposto sobre Produtos Industrializados} (IPI)

A Constituição brasileira de 1934, separando os pressupostos vendas e consumo, atribuiu à União competência para tributar o consumo ${ }^{168}$ e reservou aos Estados competência para instituir tributos sobre vendas. ${ }^{169}$

165 GUIMARÃES, Vasco Branco. A tributação do consumo no Brasil: uma visão européia. In: SARAIVA FILHO, Oswaldo Othon de Pontes; VASQUES. Sérgio (Org.). IVA para o Brasil: contributos para a reforma da tributação do consumo. Belo Horizonte: Fórum, 2007, p. 56.

166 Idem, ibidem, p. 56.

167 Doutrina especializada entende que o ISS seria um terceiro tributo incidente sobre o consumo ( $v . g$. TEIXEIRA, Alessandra Machado Brandão. A tributação sobre o consumo de bens e serviços cit.). Discordamos. É verdade que o ISS tem fato gerador bilateral e incide sobre as prestações de serviço ao consumidor final, o que, a princípio militaria em favor de sua definição como típico imposto sobre o consumo. Mas incide também sobre prestações a comerciantes, industriais e mesmo a outros prestadores de serviços, sem que haja um mecanismo jurídico de transferência integral e individualizada do ônus de tais incidências para o consumidor final. Portanto, sua repercussão para o consumidor final é apenas econômica, e não jurídica, razão pela qual entendemos não se tratar, juridicamente, de imposto sobre o consumo. 
O antigo IC - Imposto sobre o Consumo incidia apenas sobre os itens listados no respectivo regulamento, instituído pelo Decreto-lei 739/38. ${ }^{170}$ Nisso, o Brasil acompanhava a tendência da França, cuja legislação, à época, instituíra diversos impostos únicos incidentes sobre determinadas categorias de produtos mais sensíveis aos malefícios da incidência em cascata produzida pelo imposto sobre vendas então vigente (l'impôt sur le chiffre d'affaires). ${ }^{171}$

Ausente o traço de generalidade, ${ }^{172}$ o IC assemelhava-se mais àquilo que a doutrina denomina de excise taxes ${ }^{173}$ : tributos incidentes uma única vez sobre a produção, sobre a

168 “Art 6. ${ }^{\circ}$ Compete, também, privativamente à União: I - decretar impostos: [...] b) de consumo de quaisquer mercadorias, exceto os combustíveis de motor de explosão.”

169 “Art 8. ${ }^{\circ}$ Também compete privativamente aos Estados: I - decretar impostos sobre: e) vendas e consignações efetuadas por comerciantes e produtores, inclusive os industriais, ficando isenta a primeira operação do pequeno produtor, como tal definido na lei estadual; [...] $§ 10^{\circ}-\mathrm{O}$ imposto de vendas será uniforme, sem distinção de procedência, destino ou espécie dos produtos.” Na verdade, antes mesmo da CF/34, já existia o Imposto Federal sobre Vendas Mercantis, que é de 1922. A Constituição de 1934 apenas transferiu a competência para instituição desse imposto da União para os Estados.

170 Nisso, assemelhava-se ao atual IPI, que incide sobre os produtos listados na TIPI. O Regulamento a que se refere o DL 739/38, de 27/09/38, tinha o seguinte teor: "Art. $1 .^{\circ} \mathrm{O}$ imposto de consumo incide sobre os seguintes produtos: 1. Fumo. 2. Bebidas. 3. Álcool. 4. Fósforos e isqueiros. 5. Sal. 6. Calçados. 7. Perfumarias e artigos de toucador. 8. Especialidades farmacêuticas. 9. Conservas. 10. Vinagre e óleos adequados à alimentação. 11. Velas. 12. Tecidos.13. Artefatos de tecidos e de peles. 14. Papel e seus artefatos. 15. Cartas de jogar. 16. Chapéus e bengalas. 17. Louças e vidros. 18. Ferragens (artefatos de ferro e de outros metais). 19. Café torrado ou moído e chá. 20. Banha, manteiga e sucedâneos. 21. Móveis. 22. Armas de fogo, suas munições e fogos de artifício. 23. Lâmpadas, pilhas e aparelhos elétricos. 24. Queijos e requeijões. 25. Eletricidade. 26. Tintas e vernizes. 27. Leques. 28. Artefatos de borracha. 29. Pinceis para barba e obras de cutelaria. 30. Pentes, escovas, espanadores e vassouras. 31. Brinquedos. 32. Artefatos de couro e de outros materiais. 33. Jóias e obras de ourives. 34. Bijuterias, objetos de adorno e de utilidade e relógios. 35. Gasolina, óleos e carbureto de cálcio. 36. Ladrilhos e outros materiais. 37. Instrumentos de música. 38. Material ótico, fotográfico e cinematográfico. 39. Fogões, fogareiros e aquecedores. 40. Cimento. 41. Linhas, cordoalha e botões.”

171 LAURÉ, Maurice. La Taxe sur la Valeur Ajoutée. Paris: Recueil Sirey, 1952. p. 14: "En fait, de 1925 à 1935, une série de retouches furent apportées à l'impôt sur le chiffre d'affaires, sains qu'il fût procédé à une reforme d'ensemble. Ces retouches ont consisté à créer, pour chaque catégorie de produits où lês inconveniénts de la 'cascade' étainent particulièrement sensibles, une 'taxe unique', perçue une seule fois à un goulot d'etranglement, et dont la perception se substituait, d'un bout à l'autre de La chaîne, à l' 'impôt sur le chiffre d'affaires'."

172 Não obstante, "em 1946, o imposto de consumo era responsável por aproximadamente 40\% da receita tributária da União”. VARSANO, Ricardo. A evolução do sistema tributário brasileiro ao longo do século: anotações e reflexões para futuras reformas. IPEA - Instituto de Pesquisas Econômicas Aplicadas. Texto para Discussão n. 405 (os textos para discussão do IPEA têm o "objetivo de resultados de estudos desenvolvidos direta ou indiretamente pelo IPEA, bem como trabalhos considerados de relevância para disseminação pelo Instituto, para informar profissionais especializados e colher sugestões”). Rio de Janeiro, 1996, p. 8. Disponível em: <http://www.ipea.gov.br/pub/td/1996/td_0405.pdf>. Acesso em: 18 jan. 2008.

${ }^{173}$ Pode-se dizer que se tratava de um “amontoado” de exises. 
venda ou sobre o consumo de determinados tipos de bens ou grupos de bens ou sobre a realização de determinadas atividades. ${ }^{174}$

A pautar-nos pela perspectiva de Rubens Gomes de Sousa, de que se "a tributação assenta unicamente sobre uma determinada transação, seja a primeira, a última, ou qualquer das intermediárias (p. ex., na venda por atacado, ou na venda a varejo), o imposto pode ser considerado como um tributo patrimonial, gravando o valor da coisa no momento da transação tributada”, então o patrimônio era a fonte de riqueza tributada pelo antigo Imposto sobre o Consumo; só com a instituição do IPI a União passou a efetivamente tributar a circulação de riquezas, pois "somente o imposto de incidência múltipla corresponde rigorosamente ao conceito de um tributo sobre a circulação de riqueza, isto é, imposto sobre as transações civis ou comerciais [...]”. ${ }^{175}$

Foi no IC que se introduziu pela primeira vez a não-cumulatividade no Brasil (Leis 3.520, de 30/12/58 e 4.502/64, art. 25). ${ }^{176}$ Esse imposto foi oportunamente substituído pelo Imposto sobre Produtos Industrializados (IPI), de cobrança plurifásica não-cumulativa. A alteração limitou-se à nomenclatura, pois a estrutura permaneceu igual à do antigo IC ${ }^{177}$.

174 John Due, distinguindo os impostos gerais sobre vendas dos impostos especiais sobre determinadas mercadorias, anotou que "[...] the type of tax imposed upon the sale of particular commodities or groups of commodities ... may be called special or selective sales or commodity taxes, or excise taxes, although the latter term is sometimes confined to particular forms of special sales taxes, such as those imposed at the manufacturing level, or, on the other hand, extended to all taxes imposed upon activities, as distinguished from taxes on property or persons” (Sales taxation cit., p. 3).

175 A tributação das vendas cit., p. 8-9.

176 É o que relata Ricardo Lobo Torres: “a primeira experiência com o imposto não-cumulativo fez-se com o IPI, em 1958, quando ainda se denominava imposto de consumo” (É possível a criação do IVA no Brasil? cit., p. 22). No mesmo sentido: Sacha Calmon e Mizabel Derzi (ICMS - Não-cumulatividade e temas afins. In: MARTINS, Ives Gandra da Silva (Coord.) et al; Pesquisas tributárias - Nova Série - n. 10. O princípio da não-cumulatividade cit., p. 107).

177 O DL 34/66 alterou a denominação do imposto de consumo para Imposto sobre Produtos Industrializados (“Art.1. Imposto de Consumo, de que trata a Lei 4.502/64, passa a denominar-se Imposto sobre Produtos Industrializados”). 


\subsubsection{2 o Imposto sobre Vendas e Consignações (IVC) ao Imposto sobre Operações relativas à Circulação de Mercadorias (ICMS) e sobre Prestações de Serviços de Transporte Interestadual e Intermunicipal e de Comunicação}

Ainda sob a perspectiva de Rubens Gomes de Sousa anteriormente mencionada, podemos dizer que o imposto brasileiro sobre vendas e consignações foi, desde o início, um efetivo tributo sobre a circulação de riquezas, pois se impunha sobre as transações comerciais.

Sua origem é no mínimo pitoresca. Conta J. Tavares Rocha ${ }^{178}$ que as faturas mencionadas no art. 219 do Código Comercial (emitidas em duas vias, sendo uma delas a duplicata, que deveria ficar em mãos do comprador) estavam sujeitas, desde o século XIX, ao pagamento de selo proporcional, regulamentado em 1870, pelo Dec. 4.505, de 9 de abril daquele ano. Em 1908, com o advento do Dec. 2.044, de 31.12.1908, regulador da letra de câmbio e da nota promissória, passou-se a questionar se as duplicatas das faturas seriam realmente títulos de crédito. Os comerciantes, interessados em manter a cartularidade daquele título de fácil circulação, engajaram-se em projetos para afirmar-lhes a qualidade de títulos de crédito e propuseram ao governo que, em troca da "homologação" daquele desiderato, fosse instituído um imposto sobre as vendas documentadas por meio daqueles títulos. Foi assim que, em 1922, a Lei 4.625 instituiu o que, nas palavras de Alcides Jorge Costa, foi “provavelmente exemplo singular de tributo instituído por sugestão dos contribuintes”. ${ }^{179}$

O imposto sobre vendas e consignações mostrou-se um excelente instrumento arrecadatório. Ricardo Varsano relata que,

em face das limitações impostas à cobrança do imposto de exportação pela Constituição de 1934, o imposto de vendas e consignações tornou-se rapidamente a principal fonte de receita estadual correspondendo, no início da década de 40 , a cerca de $45 \%$ da receita tributária dos estado [...]. ${ }^{180}$

Prossegue o referido autor, acrescentando que, com o movimento militar da década de 60,

\footnotetext{
178 Vendas e consignações cit., p. 6.

179 COSTA, Alcides J. Imposto de vendas e consignações... cit., p. 55.

180 A evolução do sistema tributário... cit., p. 7.
} 
um novo sistema tributário foi paulatinamente implantado [...] concedendose prioridade para as medidas que, de um lado, contribuíssem de imediato para a reabilitação das finanças federais e, de outro, atendessem de forma mais urgente os reclamos de alívio tributário dos setores empresariais, que constituíam a base política de sustentação do regime: a administração fazendária federal foi reorganizada; o IR sofreu revisões que resultaram em vigoroso crescimento de sua arrecadação; e o imposto de consumo foi reformulado dando origem ao Imposto sobre Produtos Industrializados (IPI), com resultado semelhante. ${ }^{181}$

No âmbito dessa reforma, na CF 67/69, o imposto sobre vendas e consignações foi substituído pelo Imposto sobre Operações relativas à Circulação de Mercadorias (ICM), que deu vez ao ICMS, na Constituição de 1988, ambos (ICM e ICMS) não-cumulativos.

\subsection{Formas de arrecadação dos tributos sobre vendas/consumo alternativas à tributação em cascata}

O relato histórico acima demonstra que a tributação sobre vendas/consumo evoluiu da cobrança plurifásica em cascata para regimes de incidência única (monofásicos) e daí para a cobrança sobre o valor agregado.

\subsubsection{Regimes monofásicos: sobre a produção, sobre o atacado, sobre o varejo}

O tributo monofásico sobre vendas (ou de estágio singular) é aquele que incide em apenas uma etapa de toda a cadeia de circulação da riqueza.

A facilidade de arrecadação e fiscalização é um dos maiores atrativos dessa modalidade de cobrança dos tributos sobre as vendas, pois o número de contribuintes é reduzido. Em contrapartida, para se atingir o mesmo nível de arrecadação, é preciso que a alíquota seja maior ${ }^{182}$ - o que, como lembra Alcides Jorge Costa, ${ }^{183}$ pode constituir incentivo à sonegação.

\footnotetext{
181 Idem, ibidem, p. 9.

182 DUE, John F. Sales taxation cit., p. 69-70.

183 Imposto de vendas e consignações... cit., p. 62.
} 
As vantagens e desvantagens da tributação monofásica variam conforme a etapa do ciclo de circulação da riqueza em que incidam (produção, atacado ou varejo).

A tributação monofásica imposta ao nível do fabricante (produção), além de reduzir o número de contribuintes, facilitando a administração do tributo, tem o atrativo de não favorecer a integração vertical entre produtores e distribuidores. ${ }^{184}$

Sua principal deficiência consiste no fato de não extirpar inteiramente a cumulatividade do sistema, pois o imposto incidente sobre a aquisição de bens que serão utilizados como insumos no processo econômico de outros agentes não poderá ser abatido e onerará o output final. Uma alternativa é conceder suspensões do imposto para operações ocorridas no mesmo patamar - ou seja, entre fabricantes. ${ }^{185}$ José Guilherme Xavier de Basto, citado por Alessandra Brandão Machado Teixeira, explica que,

na literatura anglo-saxônica, o sistema (de suspensões) é freqüentemente designado "sistema do anel" - ring system. A expressão é sugestiva. De fato, a lei define um "anel” de contribuintes, para os quais é obrigatório o registro. No interior deste anel, as mercadorias circulam livres de impostos; só quando saem do anel - quer dizer, quando a transação é entre um sujeito passivo e um não-sujeito passivo - há lugar à imposição. ${ }^{186}$

Mas esse método não neutraliza a cumulatividade existente quando o adquirente não está no mesmo patamar do fabricante - por exemplo, é uma empresa comercial ou de prestação de serviços.

184 O mesmo não se pode dizer quanto à integração entre os fabricantes do insumo e do produto final, pois, como fabricantes, ambos estarão sujeitos ao tributo e podem entender mais lucrativo fundir suas atividades num só empreendimento.

185 John Due registra que foi esse o método adotado no Canadá nos idos de 1960. O controle se dava por meio de licenças concedidas aos fabricantes e a tributação só ocorria nas operações entre um empreendimento licenciado e um não licenciado e acrescenta que apesar de a priori complexo, por acarretar a necessidade de se analisar cada operação, na prática não causou tantos problemas nos países que o adotaram. (Sales taxation cit. p. 70 e 150).

186 A tributação do consumo e sua coordenação internacional. Cadernos de Ciência e Técnica Fiscal - Lisboa: Centro de Estudos Fiscais, 1991, p. 14. Apud TEIXEIRA, Alessandra Brandão Machado. A tributação sobre o consumo de bens e serviços cit., p. 73. 
O efeito discriminatório é outra grande deficiência desse tipo de tributação. Alcides Jorge Costa, ${ }^{187}$ na esteira de John Due, explica que, quando o tributo sobre a circulação de riquezas incide sobre a produção, o ônus tributário repercutirá de maneira desigual, produzindo efeitos discriminatórios em relação a contribuintes com margens de lucro menores e afetando a escolha do canal de distribuição. É que o ônus tributário será inversamente proporcional à margem de lucro do comerciante (seja ele o próprio produtor, o atacadista ou o varejista) que vender o produto para o consumidor final. ${ }^{188}$

Ressalte-se, ainda, que uma imposição monofásica sobre o fabricante desestimula as exportações, pois, tal como ocorre nos tributos plurifásicos cumulativos, o tributo incidido na produção repercute no preço da mercadoria em todo o seu ciclo produtivo e é difícil devolvêlo nas exportações. O cálculo é impreciso.

Além disso, o consumidor não distingue o quanto paga de imposto. Este, na expressão de John Due, o hidden effect of the tax, ${ }^{189}$ que, apesar de diminuir a oposição dos consumidores, retira a transparência do sistema tributário.

Por fim, mantida a alíquota, o governo também sai prejudicado com a incidência unifásica sobre a produção, que colhe o produto em estágio mais incipiente, sem "agregação da mais-valia subseqüente”, ${ }^{190}$ o que faz com que a base tributável seja menor.

187 Imposto de vendas e consignações... cit., p. 63.

188 Tomando-se o exemplo em que um produtor $(\mathrm{P})$ revende mercadoria pelo preço de \$100,00 (aí já incluídos seus custos e margem de lucro) a um determinado distribuidor (atacadista ou varejista) $\left(\mathrm{D}_{1}\right)$, e, dada uma alíquota fictícia de $10 \%$ para o tributo, o preço pelo qual $\mathrm{D}_{1}$ adquirirá a mercadoria de $\mathrm{P}$, será de $\$ 110,00$. Se a margem de lucro (ou, na linguagem empresarial, o markup) de $\mathrm{D}_{1}$ for de $10 \%$ sobre o preço de compra e, assumindo-se que não haja outros custos para $\mathrm{D}_{1}$, o preço para o consumidor final (C) será de $\$ 121,00$ (preço de compra:\$110,00 + markup: \$11,00). Mas se a mesma mercadoria for vendida a um segundo distribuidor $\left(D_{2}\right)$ pelos mesmos $\$ 110,00$, e a margem desse distribuidor for de $5 \%$, o preço final ao consumidor (C) será de \$115,50 (preço de compra:\$110,00 + markup: \$5,50). No primeiro caso - em que a margem de lucro do distribuidor é maior - o encargo tributário será menor, pois a tributação de $\$ 10,00$ ocorrida na fase de industrialização representa $8,2 \%$ do preço final de $\$ 121,00$; já a mesma tributação de $\$ 10,00$ representa $8,6 \%$ do preço final de $\$ 115,50$. Igual efeito discriminatório se verifica quando o fabricante vende diretamente para o consumidor final, pois, nesse caso, o produtor tem de arcar com os custos da distribuição, que vão repercutir no preço final. No exemplo acima, supondo-se que no preço de $\$ 100,00$ os custos para o produtor fossem de $\$ 80,00$ e sua margem de lucro fosse de $\$ 20,00$, e que os custos com a distribuição representem $\$ 15,00$, então o preço antes dos impostos seria de $\$ 115,00$. Sendo o tributo uma constante (no exemplo acima, 10\%), o encargo tributário para o consumidor final será de \$11,50, maior que aquele repassado aos distribuidores (\$10,00, nos dois casos), em manifesta iniquidade.

189 Sales taxation cit., p. 161. 
O tributo monofásico incidente apenas nas vendas em atacado é de administração mais complexa que aquele incidente na fabricação, dado o menor número de contribuintes a fiscalizar. Os efeitos discriminatórios em função da margem de lucro analisados anteriormente para o imposto monofásico sobre a produção também se verificam nos tributos sobre vendas em atacado. ${ }^{191}$

A suspensão de impostos do ring system abordada anteriormente também se verifica nessa modalidade de tributação monofásica sobre o atacado, com o agravante de ser maior a dificuldade de fiscalização e concessão de licenças, pois o número de contribuintes atacadistas, normalmente, é maior que o de fabricantes. ${ }^{192}$

Da obra de John Due extrai-se que, idealmente, os tributos monofásicos sobre vendas devem incidir na etapa final da circulação de riquezas, ou seja, nas vendas a varejo, feitas ao consumidor final. ${ }^{193}$

Na tributação monofásica no varejo, a repercussão desuniforme do tributo sobre os preços tende a desaparecer, pois a única margem de lucro a majorar o custo é a do varejista e, portanto, ao escolher o lojista com maior margem (lojas de luxo, por exemplo), o consumidor pagará tributo proporcional ao maior preço ali cobrado (que se presume também proporcional à maior margem daquele lojista); mas, se escolher uma loja com menor margem (como as de descontos), pagará menor preço, e, em consequência, sofrerá menor tributação. A repercussão

190 DERZI, Misabel de Abreu Machado; SANTIAGO, Igor Mauler. A harmonização dos IVAs do Brasil... cit., p. 538.

191 Nas palavras de Alcides Jorge Costa, se o imposto incide na produção ou na venda feita pelos atacadistas "cada comerciante calcula sua margem de lucro sobre o custo da mercadoria e, depois, adiciona o imposto de vendas, ressalvada a hipótese de as condições de mercado não lhe permitirem repercutir o tributo. Se este é pago pelo fabricante, a tendência do atacadista será a de calcular o seu lucro com base no custo, em que incluirá o imposto antes recolhido. $\mathrm{O}$ varejista, por seu turno, fará o mesmo [...]. O resultado é a formação de uma verdadeira pirâmide, onde aparecem margens de lucro sobre margens de lucro, tendo o imposto na base. Esse efeito, que não é estranho ao imposto de estágio múltiplo, não existe quando o tributo é cobrado no nível do varejo.” (Imposto de vendas e consignações... cit., p. 64).

192 Como as desvantagens superam as vantagens, esse tipo de tributação monofásica sobre o atacado foi historicamente pouco utilizado, tendo John Due noticiado que os países que o adotaram acabaram substituindo-o pela incidência sobre a produção; ou, quando o mantiveram, conjugaram-no com a tributação sobre a produção. Adotado na Áustria antes de sua anexação pela Alemanha, o imposto foi substituído pela tributação alemã ao nível do fabricante (umsatzsteuer) e, quando da independência austríaca, associou-se a tributação na produção com a do atacado (DUE, John F. Sales taxation cit., p. 76).

193 No mesmo sentido: COSCIANI, Cesare. El impuesto al valor agregado. Buenos Aires: Depalma, 1969. p. 10. 
econômica para o consumidor final é mais adequada porque o ônus tributário de quem adquire a mercadoria é proporcional ao preço pago e não inversamente proporcional, como no caso da tributação incidente no patamar dos fabricantes ou atacadistas.

Apesar de a administração do tributo ser mais difícil, dado o grande número de contribuintes e a usual precariedade de seus registros, a tributação no varejo enseja a instituição de alíquotas menores.

O tributo incidente sobre o varejo colherá toda a mais-valia agregada na circulação do bem, beneficiando o nível de arrecadação. Apesar de também integrar os custos da mercadoria exportada, sua interferência na formação do preço é menor, justamente porque inexiste a distorção em função das margens de lucro nas etapas anteriores. Além disso, sabese desde logo em que medida o ônus tributário interferirá na formação do preço.

O alto nível de cumulatividade residual é sua pior deficiência, pois o tributo estará incluído nos custos do adquirente, mesmo que seja outro agente econômico. Com isso, a base de cálculo do imposto pago na segunda etapa estará majorada pelo imposto pago na primeira etapa.

\subsubsection{Regime plurifásico não-cumulativo}

Como visto, a tributação sobre o valor agregado surgiu como alternativa aos inconvenientes da tributação em cascata. Foi concebida pelos economistas ${ }^{194}$ - e, por isso mesmo, por eles mais bem compreendida que pelos juristas ${ }^{195}$ - como método de apuração e recolhimento dos tributos sobre vendas, no qual o pagamento do imposto se dá de forma fracionada, distribuindo-se pelas diversas etapas de circulação da riqueza. Segundo José

194 Vasco Guimarães (A tributação do consumo no Brasil: uma visão européia cit., p. 53) discorda que a ideia da tributação sobre o valor agregado seja fruto do estudo teórico: "o IVA não foi inventado na Academia: [...] Quem criou e desenvolveu o IVA foram os técnicos da administração tributária da França que, confrontados com a evasão fiscal, adoptaram um sistema para impedi-la. Com o mecanismo de diluição de responsabilidade tributária pela entrega da receita parcelada pelos vários agentes econômicos, ao longo da cadeia de comercialização/produção lograram encontrar um sistema em que o Estado recebe efectivamente sua receita. Ou seja, é uma ciência oriunda da prática da administração e não da teoria universitária”.

195 Cf. Lobo Torres: "Os impostos sobre o valor acrescido, fruto do trabalho teórico dos economistas, sempre foram melhor compreendidos e defendidos pelos financeiros que pelos juristas” (É possível a criação de um IVA no Brasil? cit. p. 21-22). 
Eduardo Soares de Melo e Luiz Francisco Lippo ${ }^{196}$ “o objetivo da não-cumulatividade é evitar acréscimos indesejáveis de tributos que onerem artificialmente o preço do produto final.”

Essa tributação pode ocorrer por diversas formas e métodos de cálculo, que serão abordados adiante, mas, por ora, adotemos a ideia preliminar de que na tributação sobre o valor agregado tributa-se apenas o valor acrescido ao output empresarial em cada etapa do processo produtivo. Ou, como registra José Eduardo Soares de Melo, “o objetivo da nãocumulatividade é evitar a superposição de cargas tributárias que possam advir da incidência de impostos dentro de um ciclo operacional, em situação multifásica, impedindo o duplo, triplo etc., pagamento sobre a mesma base”. ${ }^{197}$

Nesse sentido, conclui Alcides Jorge Costa que se trata de mecanismo híbrido, que mescla aspectos do sistema de cobrança múltipla (plurifásico) com o de estágio singular (monofásico), aproximando-se do primeiro "por incidir sobre todas as vendas do ciclo da produção e da comercialização, com o que o impacto fica distribuído pelo produtor e pelos comerciantes" e do segundo "porque a incidência é uma só, pois cada contribuinte desconta, do imposto a pagar, o que antes incidiu sobre as vendas do mesmo produto”. ${ }^{198}$

Contorna, a um só tempo, as desvantagens tanto da tributação monofásica como da plurifásica cumulativa, pois realiza a proeza de incidir em todas as fases do ciclo econômico, como se houvesse uma única incidência. ${ }^{199}$ Com isso, torna constante o fluxo de receitas tributárias, fazendo com que a Administração seja menos dependente da solvabilidade de apenas um determinado agente econômico, pois há vários contribuintes no decorrer da cadeia. E enseja tudo isso sem sobrecarregar o setor produtivo, atendendo, pois, à neutralidade: o tributo não interfere nos hábitos de consumo, nos investimentos nem nos modelos de produção. ${ }^{200}$ Além disso, reduz as possibilidades de sonegação e facilita a administração do

\footnotetext{
${ }^{196}$ A não-cumulatividade tributária (ICMS, IPI, ISS, PIS e Cofins). 3. ed. São Paulo: Dialética, 2008. p. 146.

197 Contribuições sociais no sistema tributário cit., p. 285.

198 Vendas e consignações cit. p. 67.

199 Essa proeza foi ressaltada por: DERZI, Misabel de Abreu Machado; SANTIAGO, Igor Mauler. A harmonização dos IVAs do Brasil... cit., p. 541.

200 FALCÃO, Maurin Almeida. Da tributação cumulativa... cit., p. 618.
} 
tributo, pois, na sequência de operações tributáveis, cada contribuinte fiscalizará o outro. Por fim, distribui de forma mais uniforme a carga tributária entre os agentes econômicos. ${ }^{201}$

Clara K. Sullivan - economista pela Universidade de Columbia, NY, nos Estados Unidos, e pesquisadora de economia para o International Program in Taxation da Escola de Direito da Universidade de Harvard, MA, Estados Unidos - analisa a tributação sobre o valor agregado sob três perspectivas: como um tributo incidente sobre os agentes econômicos (tax on value added as a business tax); ${ }^{202}$ como forma de implementar, indiretamente, a tributação sobre a renda; ou como método de arrecadação dos tributos sobre venda.

A não ser pela primeira perspectiva, em que o tributo é visto como a contrapartida pelo benefício que o Governo propicia aos empresários ao colocar à sua disposição a infraestrutura que reduz as despesas necessárias à manutenção do negócio, ${ }^{203}$ nas demais, o agente econômico é mero coletor do tributo, pois o encargo é repassado aos consumidores pelo mecanismo de preços.

Para explicar a segunda perspectiva, a autora recorre a conceitos macroeconômicos e expõe que, como o produto da atividade econômica de um país equivale à renda produzida pela nação, a tributação sobre o valor agregado pode ser analisada como forma de tributar indiretamente o rendimento nacional ${ }^{204}$ porque o valor que cada empreendimento agrega ao produto durante o ciclo de produção equivale à renda agregada por aquele empreendimento ao total da renda nacional. ${ }^{205}$

201 Como explica Clara K. Sullivan, nos tributos sobre valor acrescido, o encargo será o mesmo independentemente do valor agregado nos diferentes estágios de produção; já nos tributos monofásicos, quanto maior o valor agregado nas etapas iniciais da produção ou circulação da mercadoria, maior será o impacto no encargo final a ser repassado ao consumidor (The tax on value added cit., p. 14).

202 Idem, ibidem, p. 37-47.

203 John Due, entende que, por isso mesmo, não se trataria, nessa visão, de um tributo sobre a circulação de riqueza, mas sim, espécie de taxa pela autorização concedida pelo Poder Público para funcionamento do empreendimento comercial ou industrial (Sales taxation cit., p. 4).

204 “Because output or product is merely an alternative view of the nation's income, value added may also be regarded as society's aggregate income. Value-added taxation is therefore closely related to direct income taxation, differing from the latter only by its impersonal character and its method of allocating the base among taxpayers” (The tax on value added cit., p. 285).

205 A autora registra que, a rigor, também os tributos sobre vendas monofásicos ou plurifásicos em cascata, que denomina general turnover taxes, poderiam ser substitutos da tributação sobre a renda. Mas deixa de incluílos em seus estudos por entender que suas desvantagens - notadamente a distribuição irracional da carga 
Sob essa ótica, como o encargo do tributo é transferido tanto para os bens de consumo como para os bens de investimento, ${ }^{206}$ considerando-se que, em macroeconomia, os investimentos da sociedade são financiados pela renda poupada pelos indivíduos, o tributo atingirá a renda total, consumida ou acumulada. ${ }^{207}$

Encarado como tributo indireto sobre a renda, o tributo sobre o valor agregado pode ser arrecadado de duas formas.

Na primeira, o legislador estabelece que cada contribuinte reporte anualmente seus dispêndios e que sobre eles incidirá determinada alíquota (método direto ${ }^{208}$ ou spendings $\left.\operatorname{tax}^{209}\right)$.

Na segunda, o legislador instituirá tributos sobre as vendas, a serem pagos pelos agentes econômicos, mas suportados pelo consumidor final, ${ }^{210}$ bastando estabelecer que, a cada compra, o indivíduo pague o respectivo tributo, mediante aplicação de uma determinada alíquota. Essa alíquota produzirá um aumento específico nos preços e, consequentemente,

tributária entre os agentes econômicos e consumidores e os prejuízos para o comércio internacional retiram-lhes a aptidão para figurarem na economia como substitutos da tributação da renda (The tax on value added cit., p. 24, nota 33).

${ }^{206}$ Confira-se John Due: "In practice no sales tax is confined strictly to the sale of consumption goods, since some sales of producer's goods, including capital equipment, fall within the scope of the taxes. As these elements of the tax constitute costs for the business firms, they tend to pass forward into the prices charged to the final consumer, and thus lead to retail price increases in excess of the amount of tax imposed on the final retail sales. If these items constituted a uniform percentage of the prices of all consumer goods, their taxation would not alter the overall pattern of distribution. But in fact this is not the case, and thus the prices of some goods will be raised more than those of others. As a consequence, the consumers spending relatively high percentages for the former goods will bear a relatively greater proportion of the burden of the tax than those buying relatively large quantities of other goods. The consequent shifting of demand and output will, in turn, cause some shifts in the prices of specializes factors, and alter the burden pattern still more. (...) The application of the tax to capital equipment may have some effects upon the volume of investment. (...) The requirement of a greater sum of money capital may tend to reduce somewhat the volume of investment, whether or not the interest rate rises, with consequent effects upon the level of output” ( Sales taxation cit., p. 20).

207 A renda individual poupada será (indiretamente) alcançada pelo imposto sobre vendas no momento em que os agentes econômicos adquirirem os bens do ativo fixo e demais instrumentos de produção gravados por aquele imposto.

SULLIVAN, Clara. The tax on value added cit., p. 26.

209

DUE, John F. Sales taxation cit., p. 39.

${ }^{210}$ Para John Due, o repasse do encargo do tributo ao consumidor final é da essência dos tributos sobre vendas (Sales taxation cit., p. 14). 
diminuirá a renda do consumidor no mesmo montante que o faria a alíquota incidente diretamente sobre as vendas (método indireto ${ }^{211}$ - consumptions tax ou sales tax). ${ }^{212}$

Na terceira perspectiva, forte nas já mencionadas vantagens da tributação plurifásica não-cumulativa, a autora enxerga a tributação sobre o valor agregado como um improved turnover tax, ${ }^{213}$ i.e, uma forma mais elaborada dos tributos sobre receitas de vendas.

\subsubsection{Formação da base tributável: tipo consumo, tipo renda e tipo produto bruto}

Como visto, a tributação sobre o valor agregado pode ser analisada como uma tributação sobre o output empresarial total. Tendo em vista que, para a produção desse output, o agente econômico precisa adquirir, além dos bens que se incorporam ao produto final (matérias-primas, materiais secundários e embalagens - insumos, lato sensu), máquinas, ferramentas e outros que, normalmente, são contabilizados no ativo imobilizado - designados bens instrumentais ${ }^{214}$ - o tributo variará conforme seja permitida a dedução do valor correspondente às aquisições desses instrumentais, pois os valores dos insumos sempre serão deduzidos para formação da base tributável de um tributo sobre o valor agregado.

Alcides Jorge Costa, ${ }^{215}$ com apoio em Clara Sullivan, explica que, se não for permitida a dedução do valor correspondente às aquisições dos instrumentais de produção incorporados ao custo do output empresarial (ou do valor dos tributos incidentes sobre elas), o tributo sobre o valor agregado será denominado tipo produto bruto, pois sua base total corresponde ao total rendimento global da nação, sem nenhuma exclusão, isenção ou depreciação; se for permitida a dedução correspondente à depreciação daqueles bens (ou do tributo proporcional à depreciação), o tributo será considerado do tipo renda, pois incide

${ }^{211}$ São palavras da autora: “[...] under the indirect approach it is necessary that the sales tax apply to sales of investment goods destined for final business use as well as to sales of products destined for ultimate consumption. In other words, the tax applies to business purchases of goods customarily capitalized and depreciated rather than expensed. Thus the savings of individuals are reached indirectly through their use by business firms in purchasing investment goods" (The tax on value added cit., p. 26).

212 Em ambos os casos, a renda poupada poderá ser atingida, mas somente se e quando ulteriormente destinada ao consumo - daí considerar-se o tributo invariavelmente direcionado ao consumo (idem, ibidem, p. 32).

213 Idem, p. 11-16.

214 A expressão bens instrumentais é usada por Alcides Jorge Costa em ICM - Estrutura na Constituição e na lei complementar cit., p. 24 e por Paulo Bonilha, IPI e ICM fundamentos da técnica não-cumulativa cit., p. 35.

215 ICM - Estrutura na Constituição e na lei complementar cit., p. 24. 
sobre base equivalente à renda líquida nacional; sendo permitido o desconto do total dos investimentos em bens instrumentais ou do imposto sobre eles incidente - ou não sendo eles tributados - o imposto será do tipo consumo.

Feitas essas observações e adotando a linguagem de Paulo Bonilha, é possível abordarmos as formas de cálculo e os métodos de cálculo do tributo sobre o valor agregado.

\subsubsection{Forma de cálculo do tributo: base pura ou financeira}

Reportando-se aos estudos de Cesare Cosciani, Paulo Bonilha refere-se à existência de duas formas de cálculo do valor acrescido: a pura ou sobre base real e a sobre base financeira. $^{216}$

Informa que a primeira é de difícil aplicação e não utilizada na prática, pois

pressupõe a adoção de métodos estatísticos e de avaliação de estoque, a fim de se apurar o valor acrescido mediante a dedução do valor da produção de um determinado período (incluindo-se produtos vendidos e em estoque) da cifra correspondente aos gastos de aquisição das matérias-primas, materiais secundários e equipamentos utilizados na produção desses bens. ${ }^{217}$

A segunda forma (base financeira), adotada na prática pelas legislações de diversos países, reporta-se ao total das vendas: em vez de apurar o valor efetivamente agregado em cada produto, apura-se o montante total agregado em dado período, por meio do seguinte cálculo: do total das vendas em determinado período, deduz-se o total das aquisições de matérias-primas, materiais secundários, embalagens (insumos) e bens instrumentais.

3.3.2.3 Métodos de cálculo: aditivo, subtrativo e variantes do último (base contra base e tributo contra tributo)

Os métodos de cálculo do tributo sobre o valor agregado também podem variar. Em sentido amplo, todos visam a que cada agente econômico seja responsável por recolher aos

\footnotetext{
216 No mesmo sentido, Troncoso y Troncoso, citado por Sacha Calmon Navarro Coelho e Misabel Abreu Machado Derzi, ICMS - Não-cumulatividade e temas afins. In: MARTINS, Ives Gandra da Silva (Coord.) et al. Pesquisas tributárias - Nova Série - n. 10. O princípio da não-cumulatividade cit., p. 117.

217 BONILHA, Paulo B. IPI e ICM fundamentos da técnica não-cumulativa cit., p. 33.
} 
cofres públicos apenas a parcela do tributo proporcional à sua contribuição ao ciclo econômico. ${ }^{218}$ Vale dizer, cada agente econômico recolhe o tributo sobre o valor que sua interferência no ciclo produtivo tenha agregado ao produto final. ${ }^{219}$

No método aditivo, faz-se o somatório de todos os componentes do custo do output empresarial: salários, juros, lucro, depreciações, etc., ${ }^{220}$ extraindo-se diretamente da contabilidade das empresas o valor sobre o qual incidirá a alíquota do tributo. Dizer quais valores devem ser computados para tal finalidade é tarefa que depende essencialmente da forma de encarar os investimentos realizados na atividade empresarial (fatores de produção). Isto é, pode-se permitir o cômputo de todos ou de apenas alguns dos fatores instrumentais de produção, adotando-se, portanto, qualquer uma das três modalidades de tributo sobre o valor agregado abordadas supra (tipo consumo, tipo renda ou tipo produto bruto).

No método subtrativo, ou se calcula o valor adicionado a partir da base, confrontando-se o montante das vendas com o das aquisições ocorridas no mesmo período daí a denominação de método subtrativo, variante base sobre base -, ou se faz a conta a partir do imposto incidente sobre as vendas e o imposto incidente sobre as aquisições, sempre considerado o mesmo período - daí a doutrina designá-lo método subtrativo, na variante

${ }^{218}$ Misabel Derzi e Sacha Calmon Navarro Coelho, citando Heinrich Rauser (Steuerlehre, Winklers Verlag, 1983, p. 32), registram que o IVA é "um imposto que, incidindo em todas as fases de produção e circulação, procura, por meio da 'dedução do imposto pago na operação anterior, alcançar apenas a circulação mercantil líquida de cada empresa, ou seja, tributar apenas o valor adicionado por ela. Daí os conceitos de imposto sobre vendas líquidas ou imposto sobre o valor adicionado (Mehrwersteuer)" (ICMS - Não-cumulatividade e temas afins cit., p. 107).

${ }^{219}$ Certos autores têm afirmado que existem quatro ou cinco métodos de implementação da nãocumulatividade, que viriam aos pares. Fabiana del Padre Tomé (Natureza jurídica da "não-cumulatividade" cit., p. 542-543) adota divide-os em diretos e indiretos, dizendo que cada um comporta duas subespécies, a aditiva e a subtrativa. O método direto encontraria a base efetivamente agregada seja subtraindo-se, do valor dos produtos saídos o montante dos produtos entrados (esse equivaleria ao método "base sobre base"), seja adicionando-se os valores dos diversos fatores de produção para, então, encontrar a base agregada, sobre a qual aplicar-se-ia a alíquota do tributo. No método indireto, o confronto a determinar o valor de imposto a pagar seria feito por das alíquotas. No indireto subtrativo, que entende aplicável ao IPI e ao ICMS, a diferença entre a alíquota da saída e a da entrada resultaria no valor a pagar. No método indireto aditivo, aplicar-se-ia a alíquota do imposto sobre cada um dos fatores de produção e o resultado indicaria o valor a recolher. Relata que, Edison Carlos Fernandes acrescenta a esses métodos o "método de crédito do tributo" que, no entender da autora, equivaleria ao método indireto subtrativo. Na linha de Edison Fernandes, Milton Carmo Assis Jr. (A não-cumulatividade do PIS e da Cofins. Revista Tributária e de Finanças Públicas, n. 64, p. 108-109), fala em cinco métodos, dizendo que o IPI e o ICMS adotam o "método de crédito e débito do tributo", no qual o montante incidente em etapas anteriores gera crédito a ser compensado com o débito das operações subsequentes.

${ }^{220}$ SULLIVAN, Clara. The tax on value added cit., p. 7. 
imposto sobre imposto ou crédito sobre crédito ${ }^{221}$ (ou tributo sobre tributo, caso não se esteja a falar de imposto, na classificação do CTN).

Trancoso y Trancoso, invocado por Sacha Calmon Navarro Coelho e Misabel Derzi, ${ }^{222}$ diz que o método subtrativo foi adotado pela maioria dos países em virtude de sua relativa simplicidade, muito embora o método aditivo seja o mais preciso.

\subsection{Desdobramentos do método subtrativo: créditos físicos e créditos financeiros}

Tal como no método aditivo, em qualquer das variantes do método subtrativo também é necessário saber o que será deduzido: se apenas os insumos, ou seja, as matériasprimas, materiais de embalagem, materiais secundários, ou se também os bens instrumentais, assim entendidos como os investimentos no ativo fixo.

Alcides Jorge Costa ${ }^{223}$ relata que, originalmente, na França, falava-se em crédito físico se apenas os ingredientes físicos do produto pudessem ser deduzidos e em crédito financeiro se também os instrumentais comportassem dedução. Em 1968, com a alteração da legislação francesa, o relevante era saber se geravam direito ao crédito as aquisições de bens imobilizados (parte da dedução financeira) e bens não imobilizados (dedução física) e serviços (restante da dedução financeira). Mas as expressões crédito físico e financeiro continuaram a ser usadas para designar, sucintamente, o creditamento relativo a matériasprimas, materiais secundários, produtos intermediários e embalagens (crédito físico) e a bens instrumentais, do ativo fixo (crédito financeiro).

3.3.2.3.2 Consequências da adoção das variantes dos métodos de cálculo subtrativo: isenções e alíquotas zero, efeitos de recuperação e mecanismos de regulação

Segundo Clara Sullivan, o método subtrativo na modalidade tributo contra tributo é o mais adequado quando se pretende implementar a tributação sobre o valor agregado do tipo

\footnotetext{
221 COSTA, Alcides Jorge. ICM - Estrutura na Constituição e na lei complementar cit., p. 26.

222 ICMS, não-cumulatividade e temas afins cit. p. 118.

223 Cf. ICM - Estrutura na Constituição e na lei complementar cit., p. 27.
} 
consumo ou do tipo renda bruta. Já o método aditivo é mais adequado à tributação do tipo renda. $^{224}$

Acrescenta aquela autora que o método subtrativo na variante imposto contra imposto produzirá o mesmo resultado que o método subtrativo na modalidade base sobre base desde que (i) seja permitido ao contribuinte creditar-se também do tributo incidente sobre os chamados bens instrumentais; (ii) nenhuma operação seja isenta; e (iii) não haja diferenças de alíquotas nos diversos estágios do ciclo de circulação produtivo ou de circulação da riqueza. ${ }^{225}$ Se houver diferenciação de alíquotas, o que inclui as isenções, então o método mais eficiente é o de crédito contra crédito (tax credit method), em que a alíquota efetiva final poderá equivaler à alíquota estipulada na legislação. ${ }^{226}$

Alcides Jorge Costa, com apoio em J. J. Philippe, explica as assertivas de Clara Sullivan, demonstrando que a adoção de uma ou de outra variante do método subtrativo produzirá resultados diferentes, pois na forma tributo contra tributo "as alíquotas das fases ulteriores exerce influência nas fases precedentes”. ${ }^{227}$ Confira-se o exemplo de J. J. Philippe, citado pelo tributarista brasileiro:

O contribuinte B compra de A, por 100, determinado produto que revende por 200. Eis as hipóteses:

a) Alíquota uniforme de $10 \%$

Cálculo base sobre base: $(200-100)$ x 10\% $=10$

Cálculo imposto sobre imposto: $(200 \times 10 \%)-(100 \times 10 \%)=10$

b) Alíquota de $5 \%$ nas vendas de $\mathrm{A}$ e de $10 \%$ nas vendas de $\mathrm{B}$

Cálculo base sobre base: $(200-100)$ x 10\% $=10$

Cálculo imposto sobre imposto: $(200 \times 10 \%)-(100 \times 5 \%)=15$

c) Alíquota de $15 \%$ nas vendas de A e de $10 \%$ nas vendas de B

Cálculo base sobre base: $(200-100)$ x 10\% $=10$

224 SULLIVAN, Clara. The tax on value added cit., p. 286.

225 Idem, ibidem, p. 8: "The tax-credit procedure will always give the same results as the other methods provided that the credits are allowed on products classified as intermediate under the other approaches, provided that no sales are exempt from tax, and provided that there is no other differentiation of tax rates at different stages".

226 Idem, p. 10.

227 ICM - Estrutura na Constituição e na lei complementar cit., p. 27. 
Cálculo imposto sobre imposto: $(200 \times 10 \%)-(100 \times 15 \%)=5$ (AJC, p. $26-$ 27).

Disso decorrem duas consequências:

A primeira é que, se houver isenção ${ }^{228}$ no meio da cadeia e não for permitido que o contribuinte subsequente àquele que tiver sido agraciado com a isenção tome o crédito que lhe caberia caso não houvesse norma isentiva, o Fisco recuperará a diferença nas operações seguintes e o tributo tornar-se-á cumulativo. É o chamado efeito de recuperação ${ }^{229}$. Adaptando o exemplo de J. J. Philippe teríamos o seguinte:

* Alíquota de $0 \%$ nas vendas de A e de $10 \%$ nas vendas de B

Cálculo base sobre base: $(200-100)$ x 10\% = 10

Cálculo imposto sobre imposto: $(200 \times 10 \%)-(100 \times 0 \%)=20$

Ou seja, não havendo crédito, a pretendida isenção funcionará como um diferimento, porque a diferença do tributo que deixou de incidir numa determinada etapa será recuperada pelo Fisco por meio da alíquota maior que incidirá na etapa seguinte. O tributo se torna cumulativo, pois o encargo jurídico será repassado ao consumidor final como se não tivesse havido isenção. Nesse sentido manifestaram-se Hugo de Brito Machado:

Pode parecer que, não tendo sido cobrado o IPI na operação anterior, em face da isenção, inexistiria o direito ao crédito. Tal entendimento, porém, levaria à supressão pura e simples das isenções, que restariam convertidas em meros diferimentos de incidência. Em casos como o de que se cuida, o incentivo consubstanciado na isenção concedida às indústrias sediadas em Manaus restaria inteiramente anulado. O que a Fazenda deixasse de arrecadar, a título de IPI, do produtor da matéria-prima, no Amazonas, seria

${ }^{228}$ O resultado não variará (i) mesmo que, em vez de isenção, esteja-se diante de alíquota zero e (ii) independentemente de se entender que os conceitos de isenção e alíquota zero são iguais (DERZI, Misabel. Direito tributário, direito penal e tipo cit., p. 284-285 e Paulo de Barros Carvalho, Isenções tributárias do IPI, em face do princípio da não-cumulatividade, Revista Dialética de Direito Tributário, v. 33, p. 166, São Paulo: Dialética), ou que a isenção e alíquota zero são conceitos diversos (COELHO, Sacha Calmon Navarro. Curso de direito tributário brasileiro. 3. ed. Rio de Janeiro: Forense, 1999. p. 174-175).

${ }^{229}$ Alcides Jorge Costa registra que o aspecto positivo desse efeito de recuperação é permitir saber o ônus de cada produto quando se pretender uma exoneração total (v.g. exportações). ICM - Estrutura na Constituição e na lei complementar cit., p. 27. 
por ela tranqüilamente recuperado, com a cobrança das empresas que utilizam aquela matéria-prima. ${ }^{230}$

e também Ulhôa Canto:

[...] o direito ao crédito do IPI relativo a operações anteriores cobertas por isenção integra, necessariamente, o sistema da não-cumulatividade que lhe é próprio, além de constituir a única maneira de a própria isenção ser efetiva e operar seus efeitos planos. De fato, tratando-se, como no caso em exame, de isenção objetiva, outorgada em relação a imposto que vai incidindo em fases sucessivas de um processo econômico que inclui a produção e a circulação de produtos industrializados, enquanto dure a fase de sua industrialização, somente se permitindo ao seu beneficiário que colha o mesmo efeito que normalmente resultaria para ele se isenção não existisse, é possível torná-la real e eficaz. ${ }^{231}$

Mesmo admitindo-se o creditamento, permanece o problema de saber qual a alíquota aplicável. O correto seria transportar todos os créditos das operações anteriores, o que é quase impraticável, dada a dificuldade de acesso do contribuinte que tomará o crédito aos registros das operações anteriores. A conclusão é que num tributo sobre o valor agregado (nãocumulativo), a isenção, para ser efetiva, deve ser concedida ou no início ou no fim da cadeia.

A segunda consequência da concessão de isenções no meio da cadeia é que, na situação inversa, em que o produto final é isento e bem instrumental ou insumo usado na sua produção é tributado, haverá um ônus ao contribuinte, caso não seja permitido ao vendedor do produto isento usar o crédito das fases anteriores. O direito francês vedava esse creditamento por meio do mecanismo de regularização (ou regra da reversão), segundo o qual o crédito relativo ao produto/serviço saído deveria ser estornado ou devolvido em espécie aos cofres públicos. $^{232}$ Mas essa era, como registra Alcides Jorge Costa, uma limitação ao crédito. Donde podemos concluir que, na situação normal, sem limitações, o crédito deve ser mantido, pois necessário para evitar a cumulatividade do sistema.

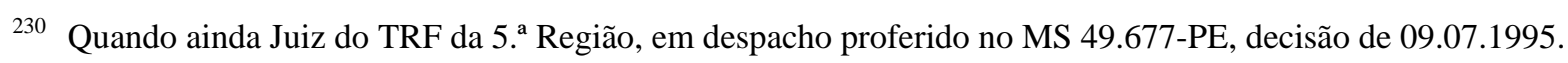

231 Não-cumulatividade. Direito à compensação de créditos referentes a matéria-prima isenta. Disciplina diferente da que prevalece atualmente em relação ao ICMS. Isenção, natureza e efeitos jurídicos. Direito tributário aplicado - Pareceres. São Paulo: Forense Universitária, 1992. p. 373-375.

232 COSTA, Alcides Jorge. ICM - Estrutura na Constituição e na lei complementar cit., p. 28. 


\subsection{A não-cumulatividade dos tributos brasileiros sobre vendas/consumo na $\mathrm{CF} / 88$}

\subsubsection{IPI e ICMS: base financeira, método subtrativo, variante imposto contra e imposto}

A CF/88 manteve a não-cumulatividade tanto do IPI como do ICMS, ${ }^{233}$ adotando a base financeira (não a base real) e o método subtrativo, na modalidade imposto contra imposto. ${ }^{234}$ Ou seja, a compensação se realiza por período, abatendo-se, de cada operação, o valor anteriormente incidido nas operações anteriores, ${ }^{235}$ de modo a evitar a incidência cumulativa de impostos na cadeia produtiva. Considera-se o total das mercadorias (ou serviços, no caso do ICMS), entradas e saídas, sendo irrelevante que as operações de saída tributadas digam respeito a mercadorias (ou serviços) distintas das que geraram os créditos. ${ }^{236}$

3.4.2 ICMS e IPI: distinção quanto aos efeitos de recuperação e mecanismos de regulação (ou regra de reversão)

A distinção entre a não-cumulatividade do IPI e do ICMS, na CF/88, verifica-se relativamente às operações em que exista isenção ou não-incidência - que, para o ICMS, não geram créditos a serem abatidos nas operações seguintes e acarretam o estorno dos créditos

233 “Art. 153. Compete à União instituir impostos sobre [...] IV - produtos industrializados; § 3. ${ }^{\circ}$ - O imposto previsto no inciso IV: [...] II - será não-cumulativo, compensando-se o que for devido em cada operação com o montante cobrado nas anteriores;" "Art. 155. Compete aos Estados e ao Distrito Federal instituir impostos sobre: [...] II - operações relativas à circulação de mercadorias e sobre prestações de serviços de transporte interestadual e intermunicipal e de comunicação, ainda que as operações e as prestações se iniciem no exterior; [...] § 2. ${ }^{\circ} \mathrm{O}$ imposto previsto no inciso II atenderá ao seguinte: será não-cumulativo, compensando-se o que for devido em cada operação relativa à circulação de mercadorias ou prestação de serviços com o montante cobrado nas anteriores pelo mesmo ou outro Estado ou pelo Distrito Federal; II - a isenção ou não-incidência, salvo determinação em contrário da legislação: a) não implicará crédito para compensação com o montante devido nas operações ou prestações seguintes; b) acarretará a anulação do crédito relativo às operações anteriores;".

${ }^{234}$ Roque Carrazza (ICMS. 5. ed. rev. atual. São Paulo: Malheiros, 1999) entende que o ICMS não é propriamente um imposto sobre o valor agregado, porque grava o valor total da operação. Cita José Souto Maior Borges (Lei Complementar Tributária - São Paulo, Ed. Revista dos Tribunais, 1975, pp. 160-161), para quem “a agregação de valor não é ‘elemento’ essencial à integração da hipótese de incidência do ICM. [...] Do contrário, [...] numa venda de mercadoria abaixo do preço de custo, o contribuinte não teria nem mesmo que debitar-se sobre o valor da saída, porque faltar-lhe-ia o 'elemento financeiro do fato gerador'." Discordamos dos referidos autores: a agregação de valor se verifica no período de apuração, e não em cada operação, isoladamente.

235 “O vocábulo 'cobrado’ não pode ser entendido no sentido de concretamente exigido. Seria irreal pretender que o adquirente soubesse se o Estado exigiu ou não, concretamente, o ICM que incidiu sobre a operação. $\mathrm{O}$ sentido de cobrar só pode ser o de incidir”. COSTA. Alcides Jorge. ICM - Estrutura na Constituição e na lei complementar cit., p. 156.

${ }^{236}$ Cf. Sacha Calmon Navarro Coelho e Misabel Derzi, ICMS - Não-cumulatividade e temas afins. cit, p. 119. 
relativos às operações anteriores, exceto nas situações previstas nos arts. $20, \S 6 .^{\circ}{ }^{237}$ e 21 , § 3. , ${ }^{238}$ da LC 87/96. Ou seja, aplicam-se, para o ICMS, os efeitos de recuperação e os mecanismos de regulação (ou regra de reversão) abordados no item precedente ${ }^{239}$.

Essa restrição ao creditamento do ICMS em operações isentas ou em operações nas quais não tenha havido incidência foi introduzida, já na constituição pretérita, pela EC 23/83, em resposta à construção jurisprudencial do STF, que reconhecia o direito ao crédito mesmo diante de isenção. Significativa maioria dos autores ${ }^{240}$ entende que a lei constitucional laborou em erro ao restringir o creditamento nessas hipóteses, mas há quem sustente que o equívoco jurisprudencial é que foi corrigido pelo legislador constituinte. ${ }^{241}$

Na corrente majoritária, Sacha Calmon Navarro Coêlho, ${ }^{242}$ por todos, explica que as exonerações concedidas numa determinada fase do processo econômico de circulação quebram a cadeia de transmissão do crédito e tornam o tributo cumulativo. Se o crédito relativo às operações anteriores à isenta é estornado e não há geração de crédito simbólico, o valor do imposto se agrega ao preço e será novamente tributado na primeira operação

237 “Art. 20. Para a compensação a que se refere o artigo anterior, é assegurado ao sujeito passivo o direito de creditar-se do imposto anteriormente cobrado em operações de que tenha resultado a entrada de mercadoria, real ou simbólica, no estabelecimento, inclusive a destinada ao seu uso ou consumo ou ao ativo permanente, ou o recebimento de serviços de transporte interestadual e intermunicipal ou de comunicação. [...] $\S 6$. $^{\circ}$ Operações tributadas, posteriores a saídas de que trata o $\S 3 .^{\circ}$, dão ao estabelecimento que as praticar direito a creditar-se do imposto cobrado nas operações anteriores às isentas ou não tributadas sempre que a saída isenta ou não tributada seja relativa a: I - produtos agropecuários; II - quando autorizado em lei estadual, outras mercadorias.”

238 “Art. 21. O sujeito passivo deverá efetuar o estorno do imposto de que se tiver creditado sempre que o serviço tomado ou a mercadoria entrada no estabelecimento: [...] $\S 3 .^{\circ}$ O não creditamento ou o estorno a que se referem o $\S 3 .^{\circ}$ do art. 20 e o caput deste artigo, não impedem a utilização dos mesmos créditos em operações posteriores, sujeitas ao imposto, com a mesma mercadoria.”

${ }^{239}$ Entretanto, essa distinção entre a não-cumulatividade do ICMS e do IPI está atualmente em revisão no STF. A negativa de créditos para insumos com alíquota zero (e a possível denegação também em caso de insumos isentos) vai no sentido de aproximar os impostos, apesar de apenas um ser objeto de exceção expressa na $\mathrm{CF} / 88$.

240 Citemos, exemplificativamente, Alcides Jorge Costa (taxativamente no que diz respeito à manutenção do crédito relativo a operações anteriores à isenta e, implicitamente, no que tange à isenção na mercadoria saída - ICM - Estrutura na Constituição e na lei complementar cit., p. 134 e 27-28, respectivamente), Geraldo Ataliba, Misabel Derzi e Sacha Calmon.

241 Cf. TORRES, Ricardo Lobo. O IVA no direito comparado cit., in MARTINS, Ives Gandra da Silva (coord.); BARRETO, Aires Fernandino (colab.) [et al]. Pesquisas Tributárias. Nova Série; 10 - O princípio da nãocumulatividade São Paulo: Centro de Extensão Universitária/Revista dos Tribunais, 2004. p. 152-153.

${ }^{242}$ O IVA brasileiro. In: SARAIVA FILHO, Oswaldo Othon de Pontes; VASQUES, Sérgio; GUIMARÃES, Vasco Branco (Org.). IVA para o Brasil Contributos para a reforma da tributação do consumo. Belo Horizonte: Fórum, 2007. p. 558-559. 
posterior à beneficiada. É dizer, não havendo crédito, o montante de imposto que o adquirente terá que pagar ao final do período de apuração será maior. Considerando-se que, no Brasil, a não-cumulatividade tanto do IPI como do ICMS se realiza por período, e não por mercadoria ou serviços, à falta desse crédito, o adquirente da mercadoria pagará o imposto devido pelo contribuinte beneficiado com a isenção. Daí a necessidade de concessão do crédito, ainda que possa ser considerado apenas presumido/simbólico.

Ricardo Lobo Torres ${ }^{243}$ concorda que a concessão de isenções no meio da cadeia de circulação acarreta cumulatividade ao sistema, pois o Estado cobrará o tributo correspondente às etapas isentas por força do chamado efeito de recuperação. Mas diz que o direito ao crédito seria obra de ficção jurídica; tratar-se-ia de crédito presumido (benefício/incentivo fiscal), e não de crédito real, entendido esse como o relativo a imposto efetivamente incidido na entrada. Mais adiante, referindo-se às exonerações na saída, diz que “o crédito pela entrada é usufruído sob a condição da ulterior saída tributada. (...) Para que seja real o crédito na entrada é necessário que tenha sido condicionado o crédito na saída”, ${ }^{244}$ ensejando concluirmos que, para esse tributarista, seria correto aplicar a regra de reversão do direito francês.

\subsubsection{IPI e ICMS: crédito físico vs. crédito financeiro}

Ainda no tocante à forma de cálculo desses impostos, a maioria dos autores, ${ }^{245}$ firmes em que, salvo para as hipóteses de isenção ou não-incidência do ICMS, a Constituição Federal não teria aberto nenhuma outra exceção à não-cumulatividade (seja do ICMS, seja do IPI), entende que a CF/88 reconheceu o crédito financeiro, em oposição ao crédito físico, não cabendo ao legislador ordinário restringir os insumos creditáveis apenas às matérias-primas,

\footnotetext{
243 O IVA no direito comparado cit., p. 152-153.

244 Idem, ibidem, p. 154-155.

245 Roque Carraza, Geraldo Ataliba, Misabel Derzi, Heleno Torres, entre outros. Ricardo Lobo Torres sinaliza que, para o ICMS, a constituição pretérita adotara o crédito físico, tendo a casuística do STF colaborado para a sedimentação desse critério, negando o abatimento do imposto relativo a operações com mercadorias tais como sacos e sacolas de supermercados, corpos moedores usados no processo de fabricação do cimento, ferramentas usadas na construção de bases de suporte para maquinário, etc. Mas ressalta que, a partir da CF/88, com a inclusão dos serviços de transporte interestadual e intermunicipal e de comunicação no âmbito daquele imposto, dada a evidente impossibilidade de integração física ao output empresarial, o constituinte teve que admitir o crédito financeiro, mesclando os critérios (O IVA no direito comparado cit., p. 147-149).
} 
produtos intermediários e embalagens, como fez para o IPI, ${ }^{246}$ nem postergar a fruição do crédito de materiais de uso e consumo, energia elétrica e serviços de comunicação, como tem feito a LC $87 / 96 .^{247}$

A distinção entre o crédito físico e o crédito financeiro, originada da legislação francesa, foi, no Brasil, acolhida pelos tribunais.

A jurisprudência do STF considerou creditáveis apenas os insumos que se incorporassem fisicamente ao produto final ou o material secundário que se desgastasse rapidamente na produção $0^{248}$ - esse o sistema do crédito físico para a jurisprudência. Em contrapartida, o crédito financeiro referir-se-ia aos insumos que, mesmo não se incorporando ao produto final ou não se desgastando rapidamente no processo produtivo, fossem creditáveis, tais como bens do ativo, ferramentais, energia elétrica, serviços de transporte, de comunicações, etc. Os bens do ativo que, logicamente, não integram fisicamente o produto tinham seu creditamento vedado não em decorrência da adoção do IVA tipo produto bruto, mas em virtude do equívoco do STF em supor que a Constituição havia adotado o creditamento físico.

246 Dec. 4.455/2002 “Art. 164. Os estabelecimentos industriais, e os que lhes são equiparados, poderão creditarse (Lei 4.502, de 1964, art. 25): I - do imposto relativo a MP, PI e ME, adquiridos para emprego na industrialização de produtos tributados, incluindo-se, entre as matérias-primas e produtos intermediários, aqueles que, embora não se integrando ao novo produto, forem consumidos no processo de industrialização, salvo se compreendidos entre os bens do ativo permanente; II - do imposto relativo a MP, PI e ME, quando remetidos a terceiros para industrialização sob encomenda, sem transitar pelo estabelecimento adquirente; III - do imposto relativo a MP, PI e ME, recebidos de terceiros para industrialização de produtos por encomenda, quando estiver destacado ou indicado na nota fiscal; [...]."

247 “Art. 33. Na aplicação do art. 20 observar-se-á o seguinte: I - somente darão direito de crédito as mercadorias destinadas ao uso ou consumo do estabelecimento nele entradas a partir de 10 de janeiro de 2011 (redação dada pela LC 122/2006); II - somente dará direito a crédito a entrada de energia elétrica no estabelecimento: (Redação dada pela LC 102/2000) a) quando for objeto de operação de saída de energia elétrica; (alínea incluída pela LC 102/2000) b) quando consumida no processo de industrialização; (alínea incluída pela LC 102/2000) c) quando seu consumo resultar em operação de saída ou prestação para o exterior, na proporção destas sobre as saídas ou prestações totais; e (alínea incluída pela LC 102/2000) d) a partir de 1. ${ }^{\circ}$ de janeiro de 2011, nas demais hipóteses; (Redação dada pela LC 122/2006) [...] IV - somente dará direito a crédito o recebimento de serviços de comunicação utilizados pelo estabelecimento: (Inciso incluído pela LC 102/2000) a) ao qual tenham sido prestados na execução de serviços da mesma natureza; (alínea incluída pela LC 102/2000) b) quando sua utilização resultar em operação de saída ou prestação para o exterior, na proporção desta sobre as saídas ou prestações totais; e (alínea incluída pela LC 102/2000) c) a partir de 1. . de janeiro de 2011, nas demais hipóteses. (Redação dada pela LC 122/2006).”

${ }^{248}$ Cf. exemplificativamente o RE 70.284, de 03/05/1973, Rel. Min. Thompson Flores. DJU 30.05.1973. 
Dada a inovação do STF, a doutrina passou a usar a expressão creditamento financeiro para indicar a sistemática pela qual são dedutíveis todos os elementos que, estando no campo de incidência dos referidos impostos, tenham concorrido como custo ou despesa de produção.

Nessa linha, Sacha Calmon Navarro Coêlho e Misabel Derzi ${ }^{249}$ explicam que, no IVA, a concessão de créditos relativamente a todo e qualquer tributo incidente nas compras de insumos - sejam os que se incorporem fisicamente ao produto final, sejam os bens do ativo ou gastos incorridos com outros insumos que não se integram fisicamente ao produto final, tais como energia elétrica, serviços de comunicação e transportes, mas que tenham sofrido incidência na etapa anterior - segue a premissa de que todas as aquisições feitas pelo agente econômico direcionam-se à consecução de suas atividades. Restrições ao direito de dedução só podem se referir a bens que não sejam necessários à atividade econômica ou não estejam relacionados exclusivamente às operações que traduzem o objeto social da empresa, tais como gastos pessoais de diretores e bens usados tanto para finalidades pessoais como profissionais. $^{250}$

Entende essa corrente doutrinária que, como a CF/88 adotou o método de cálculo subtrativo na variante imposto contra imposto, tanto para o IPI como para o ICMS, o perfil da não-cumulatividade ganhou status de princípio constitucional. Logo, se o insumo sofrer incidência, ensejará crédito para a etapa seguinte. Daí reputarem ilegítimas as vedações quanto ao creditamento dos materiais de uso e consumo, bens do ativo, energia elétrica e serviços de comunicações. Vale dizer, a própria CF/88 teria definido o princípio da nãocumulatividade e adotado o crédito financeiro (não o físico). Ao legislador ordinário caberiam somente tarefas adjetivas, tais como: estipular o período de apuração, a data de pagamento, quais os créditos que, não estando afetados às atividades do sujeito passivo, deveriam ser

249 ICMS - Não-cumulatividade e temas afins cit., p. 114.

250 Misabel Derzi e Igor Santiago explicam que essa foi a ratio de, no Brasil, ter-se negado, no ICMS, o crédito relativo aos serviços de comunicação, pois "pode dar-se que os diretores da empresa prefiram fazer suas ligações telefônicas do escritório e não de casa [...]”. Criticando o extremismo do legislador brasileiro, dá a solução: "mas seria irrealista pensar que não há serviços de comunicação verdadeiramente ligados ao escopo empresarial. Portanto, o que sugere o Conselho de impostos (da França) nessa situação? Uma redução do direito de crédito, por exemplo, a $50 \%$ ou $70 \%$ do valor pago, na pressuposição de que há mesmo um certo abuso. Portanto haveria uma redução que tem que ser arbitrária, porque não é possível mensurar o nível de utilização profissional e pessoal desses bens ou serviços.” A harmonização dos IVAs do Brasil... cit., p. 543. 
excluídos da compensação etc. ${ }^{251}$ Em estudo autônomo, Sacha Calmon Navarro Coêlho ${ }^{252}$ diz que o legislador ordinário também poderia explicar a forma e a periodicidade de amortização dos créditos relativos aos bens do ativo. Ou seja, poderia escolher entre o tipo consumo e o tipo renda - mas nunca o tipo produto bruto, ${ }^{253}$ pois isso implicaria vedar os créditos relativos aos bens instrumentais, contrariando o princípio constitucional da não-cumulatividade.

Raciocínio diverso - mas que conduz à mesma conclusão - é apresentado por Marco Aurélio Greco. ${ }^{254}$ Para esse tributarista, insumos podem ser econômicos ou funcionais. Dentre os primeiros estão os fatores de produção (capital e trabalho); dentre os últimos, todos os elementos que integram o processo produtivo (máquinas, equipamentos, matérias-primas, trabalho humano, embalagens, etc.). Como o pressuposto de fato do IPI remete a algo fisicamente apreensível, entende o autor que "insumo, para fins de não-cumulatividade de IPI, é conceito de aplicação restrita, pois alcança, fundamentalmente, matérias-primas, produtos intermediários e materiais de embalagem”. Completa afirmando que o fator trabalho, a rigor, também deveria integrar o conceito, mas não confere crédito para abatimento na operação seguinte porque a sistemática é de imposto contra imposto e o fator trabalho não é tributado pelo IPI.

A linha de raciocínio de Marco Aurélio Greco enseja duas conclusões: (i) o legislador ordinário poderia estipular que a formação da base do IPI segue o tipo consumo ou o tipo renda, mas não o tipo produto bruto, porque o imposto incidente sobre aquisições de bens do ativo deve ser abatido, tendo em vista a adoção do método de cálculo subtrativo, na variante imposto contra imposto; e (ii) como o constituinte de 1988 incluiu no campo de incidência do ICMS determinados serviços, ${ }^{255}$ que são prestações intangíveis, e certos bens incorpóreos ${ }^{256}$ - fatores que não se amoldam ao denominado crédito físico -, o único regime que poderia atender integralmente o comando da não-cumulatividade seria mesmo o do

\footnotetext{
251 Cf. MELO, José Eduardo Soares. LIPPO, Luiz Francisco. A não-cumulatividade tributária ... cit., p. 136137.

252 COELHO, Sacha Calmon Navarro. O IVA brasileiro cit., p. 573-574.

253 Essa conclusão é nossa, a partir das assertivas do autor.

254 Não-cumulatividade no PIS e na Cofins cit., p. 113.

255 Transporte interestadual e intermunicipal e serviços de comunicação.

256 Tal como a energia elétrica.
} 
crédito financeiro (e aqui referimo-nos à conceituação de crédito físico e financeiro da jurisprudência brasileira e não à da legislação francesa).

Tanto o primeiro argumento, de que a não-cumulatividade é princípio constitucional, como o segundo, de que a não-cumulatividade deve levar em conta o aspecto material do pressuposto de fato, conduzem à conclusão de que, no IPI e no ICMS, os bens e serviços tributados, que tenham concorrido para a produção do output geram direito a crédito. De uma maneira ou de outra, demonstram o desacerto da jurisprudência do STF ao reputar creditáveis apenas os materiais fisicamente integrados ao produto final.

Com isto, chegamos a outro ponto de controvérsias acirradas na doutrina: seria a não-cumulatividade regra ou princípio?

\subsection{Não-cumulatividade: princípio ou regra?}

Não vislumbrando na CF/88 nenhuma restrição ao creditamento (a não ser as já referidas vedação de crédito e previsão de estorno nos casos de isenção e não-incidência para o ICMS), grande parte da doutrina trata a não-cumulatividade como princípio constitucional, segundo o qual "se deve deduzir do imposto exigível em cada operação aquele imposto que gravou os elementos do preço (créditos financeiros)”. ${ }^{257}$ Afirmam que referido princípio integra o prescritor da norma tributária, traduzindo uma só relação jurídica, tanto que a quantificação do valor a pagar depende da apuração dos débitos $e$ dos créditos. ${ }^{258}$ Por isso, o creditamento não poderia sofrer restrição nenhuma por norma infraconstitucional. ${ }^{259} \mathrm{O}$ legislador ordinário não poderia nem restringir os créditos aos insumos que fisicamente se incorporem ao produto final, nem vedar o crédito dos ativos (ou seja, não poderia optar pelo tipo produto bruto).

Justificam essa tomada de posição no fato de o ICMS e o IPI terem sido instituídos para onerar o consumidor, atingindo a sua capacidade contributiva, e não o empreendedor.

\footnotetext{
257 Sacha Calmon e Misabel Derzi, ICMS - Não-cumulatividade e temas afins cit., p. 113.

258 "Fosse o direito de crédito do contribuinte autônomo e próprio, não poderia o Fisco (sujeito ativo) apurá-lo através do lançamento, que é ato administrativo” (COELHO, Sacha Calmon Navarro. O IVA brasileiro cit., p. 566).

259 Nesse sentido manifestaram-se, dentre outros, Alberto Xavier, Geraldo Ataliba, Ives Gandra da Silva Martins, José Eduardo Soares de Melo, Roque A. Carrazza, Misabel Derzi e Sacha Calmon Navarro Coelho.
} 
Advogam a tese de que a restrição ao abatimento integral dos impostos pagos na aquisição de bens instrumentais acarreta cumulatividade ao sistema e reconduz a todos os percalços que a tributação plurifásica não-cumulativa pretendeu evitar: distorção nos preços, concentração de mercado, etc. Ao que se infere, a neutralidade tributária e a capacidade contributiva seriam os fins que confeririam à não-cumulatividade a dimensão de princípio.

Sem embargo dessa respeitável posição doutrinária, é de rigor relatar o entendimento da corrente contrária, segundo a qual o legislador, constitucional ou infraconstitucional, poderia optar validamente entre regimes que conferissem ao creditamento maior ou menor amplitude $^{260}$ porque, apesar de posta na constituição, a não-cumulatividade é regra, e não princípio.

Entendem que a não-cumulatividade é regra que dá concretude aos princípios da neutralidade e da capacidade contributiva, pois, cobrados dessa forma, os tributos sobre vendas/consumo não interferem na concorrência e, sendo pagos pelo consumidor final sobre o valor efetivamente acrescido durante o processo de formação/circulação do produto, colhem sua capacidade contributiva sem impor nenhum excesso. Como registra Heleno Taveira Tôrres: “não-cumulatividade [é] técnica em favor do atendimento a tal desiderato [capacidade contributiva], na graduação da carga tributária [...]”. 261

Posição intermediária verifica-se em Ricardo Lobo Torres, ${ }^{262}$ para quem a nãocumulatividade

é um subprincípio dos diversos princípios de justiça que governam os impostos sobre o valor acrescido: repercussão legal obrigatória, neutralidade econômica, país de destino e capacidade contributiva. Não é um verdadeiro princípio jurídico porque lhe faltam as suas características básicas, a saber: a) imbricação com os princípios morais; b) dimensão de peso, que permite a ponderação de interesses. A não-cumulatividade contém características de regra. Cumpre-lhe operacionalizar [...] a concretização de todos os princípios de justiça que informam os impostos sobre o valor acrescido [...].

260 Alcides Jorge Costa, José Souto Maior Borges, Heleno Taveira Tôrres, Hugo de Brito Machado e Marco Aurélio Greco.

261 Monofasia e não-cumulatividade ... cit., p. 33.

262 O IVA no direito comparado cit., p. 144 (destaques nossos). 


\subsubsection{Princípios vs. regras}

Nossa tomada de posição a respeito dessa divergência doutrinária exige parênteses sobre tema que, em direito, sempre causou controvérsias: a distinção entre princípios e regras.

Na tradicional oposição entre positivistas e jusnaturalistas, princípios são, para os primeiros, normas que orientam a interpretação das demais, vetores de agregação, mandamentos fundamentais ${ }^{263} \mathrm{e}$, para os últimos, o próprio fundamento do direito positivo, estando a meio caminho entre as normas e os valores que buscam concretizar. ${ }^{264}$

No direito comparado, a distinção entre princípios e regras teve seu auge nas polêmicas entre Hart e Dworkin e, mais adiante, entre Dworkin e Alexy - em discussões que revelaram conceitos que vão além da tradicional distinção entre mandamentos nucleares (princípios) e instrumentos para sua operacionalização (regras). Vamos a elas, em apertadíssima síntese.

Numa perspectiva, a nosso ver, extremamente positivista, Hart, apesar de auto intitular-se "um positivista moderado", ${ }^{265}$ vislumbrava o direito como conjunto de regras e dizia que os princípios ou os valores morais são critérios de validade jurídica, critérios de direito. ${ }^{266}$ Em suas palavras,

os princípios são, relativamente às regras, extensos, gerais, ou não específicos, no sentido de que, com freqüência, aquilo que seria encarado como um número de regras diferentes pode ser apontado como exemplificações ou ilustrações de um único princípio. [...] Porque se referem mais ou menos explicitamente a um certo objectivo, finalidade, direito ou valor, [os princípios] são encarados [...] não apenas enquanto capazes de fornecer uma explicação ou fundamento lógico das regras que os exemplificam, mas também, pelo menos, enquanto capazes de contribuir para a justificação destas. ${ }^{267}$

263 Cf., exemplificativamente, Sacha Calmon: “O que caracteriza os princípios é que não estabelecem um comportamento específico, mas uma meta, um padrão. Tampouco exigem condições para que se apliquem. Antes, enunciam uma razão para a interpretação dos casos. Servem, outrossim, como pauta para a interpretação das leis, a elas se sobrepondo” (Comentários à Constituição de 1988 - Sistema tributário. 6. ed. Rio de Janeiro: Forense, 1995. p. 106).

264 TORRES, Ricardo Lobo. O IVA no direito comparado cit., p. 143.

265 Cf. seu pós-escrito à obra $O$ conceito de direito. 3. ed. Lisboa: Fundação Calouste Gulbenkian (nas oficinas de Espaço 2 Gráfico), 2001.

266 Idem, ibidem, p. 308-309.

267 Idem, p. 322. 
Seu sucessor em Harvard, Dworkin, ${ }^{268}$ afirmando que o direito se compõe de normas, que podem ser regras ou princípios, entendeu que a diferença entre os dois é de estrutura (e não de grau) e verifica-se na forma de aplicação: as regras ou valem ou não valem; os princípios, além da dimensão de validade, possuem dimensão de peso. Em caso de conflitos de regras, aplica-se uma ou outra (o famoso “tudo ou nada” de Dworkin); na colisão de princípios, o intérprete procederá ao sopesamento, aplicando o que melhor servir ao caso concreto - o que não acarreta a invalidade do princípio cuja aplicação foi posta de lado apenas momentaneamente.

Alexy ${ }^{269}$ partiu do mesmo pressuposto que Dworkin - ou seja, que a diferença entre princípios e regras é qualitativa; para ele, nada têm a ver com axiologia. Acrescentou que a aplicação dos princípios por meio do sopesamento revela tratar-se de mandamentos de otimização, que prescrevem a realização de determinada conduta, na medida do possível. Nesse sentido, os princípios orientam a interpretação das regras. Sua aplicação a cada caso concreto é limitada pelo sopesamento: expressam deveres prima facie que, justamente por isso, podem deixar de ser aplicados a um dado caso sem, contudo, perderem sua validade. Daí dizer que o grau de realização dos princípios pode variar. Já as regras expressam deveres definitivos. Se forem válidas, deve-se realizar a conduta que prescrevem, em sua inteireza.

Entre nós, contribuiu para o esclarecimento da distinção entre regras e princípios Humberto Ávila. Segundo esse renomado cientista do direito, não é nem o tipo de obrigação resultante da norma (relativa, ou dever prima facie vs. absoluta, ou dever definitivo) nem a forma de solução dos conflitos (tudo ou nada, para as regras e ponderação/sopesamento, para os princípios) que distancia as regras dos princípios. Essa dissociação se dá em três planos. Dessa pluridimensionalidade decorre que um mesmo dispositivo pode ensejar tanto a construção de uma regra como de um princípio, ou seja, existe dissociação entre princípios e regras, mas ela é inclusiva. ${ }^{270}$

\footnotetext{
${ }^{268}$ Cf. ÁVILA, Humberto B. Teoria dos princípios. 8. ed. São Paulo: Malheiros, 2008. p. 36-37.

${ }^{269}$ Cf. SILVA, Virgílio Afonso da. Princípios e regras: mitos e equívocos acerca de uma distinção. Revista Latino-Americana de Estudos Constitucionais, n. 1, p. 610-612, 2003.

270 ÁVILA, Humberto. Teoria dos princípios cit., p. 70.
} 
O primeiro critério de dissociação diz respeito ao dever instituído - não em termos de deveres provisórios (prima facie) para os princípios e deveres definitivos para as regras -, mas, sim, em termos de justificativa do dever instituído: regras instituem o dever de adotar comportamentos descritos (descrição imediata do comportamento) e princípios, o dever de adotar comportamentos necessários a tanto (descrição mediata do comportamento); ${ }^{271}$ regras prescrevem comportamentos com os quais serão atingidos determinados fins (daí seu caráter mediatamente axiológico) e princípios estabelecem o dever de realizar o estado ideal das coisas (os fins), pela adoção dos comportamentos necessários a tanto (portanto, imediatamente axiológicos). ${ }^{272}$

O segundo critério de dissociação ${ }^{273}$ é a natureza da justificação que regras e princípios exigem para serem aplicados (note-se, não é o modo de aplicação: tudo ou nada para regras e sopesamento para princípios, e sim a justificação do modo de aplicação). Como as regras têm caráter eminentemente descritivo (descrição do comportamento imediato), sua aplicação passa por avaliar a correspondência entre o fato, a norma ${ }^{274}$ e a finalidade dessa última. Em outras palavras, a ponderação também existe nas regras, mas o que se pondera é a importância das razões que determinam a adoção do comportamento em face de sua finalidade. Já nos princípios, em que é mais acentuado o elemento axiológico que o comportamental, o que se deve ponderar/avaliar é se os efeitos da conduta a ser adotada contribuem para a realização do fim e, por isso, segundo o autor, há maior necessidade de analisar casos paradigmáticos para investigar seu conteúdo normativo. ${ }^{275}$

${ }^{271}$ Pelo critério da justificação, os princípios revelam um "procedimento racional de fundamentação que permit(e) tanto especificar as condutas necessárias à realização dos valores por eles prestigiados quanto justificar e controlar sua aplicação" (ÁVILA, Humberto, Teoria dos princípios cit., p. 64), sendo, portanto, menos determinados que as regras, pois "não determinam imediatamente o objeto do comportamento, mas determinam a sua espécie” (idem, ibidem, p. 75-76).

272 Enquanto as regras determinam um comportamento, os princípios determinam um fim, a ser gradualmente realizado. Nesse sentido, regras são retrospectivas e princípios, prospectivos - mas isso não quer dizer que as regras sejam desprovidas de finalidades, pois a axiologia é inerente a qualquer norma. ÁVILA, Humberto. Ibidem, p. 49 e 180-181.

273 Idem, ibidem, p. 73-75.

274 Ou seja, subsunção do conceito/construção do fato ao conceito/descrição normativa.

275 Ávila afirma, ainda, que a diferença entre essas duas espécies normativas é o grau de abstração anterior à interpretação, maior nos princípios que nas regras, pois a ponderação é inerente à interpretação de qualquer norma (Teoria dos princípios cit., p. 48). Nesse ponto, é severamente criticado por Virgílio Silva, por entender que tanto a regra como o princípio demandam interpretação, pois são normas, e não textos. Diante disso, Virgílio Silva conclui que a diferença entre ambas continua sendo de estrutura, como salientaram 
Finalmente, o terceiro critério de dissociação ${ }^{276}$ reside na forma com que as referidas normas contribuem para a tomada de decisão: as regras têm a aspiração de gerar a solução específica para o caso concreto - pretendem abranger todos os aspectos relevantes -, ao passo que os princípios apenas contribuem para tanto, sendo mais dependentes de outras normas, das quais são complementares. ${ }^{277}$

Forte nesses critérios distintivos, Humberto Ávila - cujas lições adotamos para fins da presente pesquisa - registra as incoerências resultantes tanto do uso inconsistente da distinção fraca entre regras e princípios (a tradicional, que os distingue de acordo com o grau de abstração e generalidade, menor nas regras que nos princípios) como do uso inconsistente da distinção forte entre esses dois tipos de norma (a que os diferencia conforme a estrutura e solução de conflitos - Dworkin e Alexy).

Como exemplo de inconsistência do primeiro caso (distinção fraca), o autor relata que alguns autores, a despeito de entenderem que os princípios têm alto grau de abstração e generalidade, classificam como princípio normas que nada têm de abstratas e gerais, como a que prescreve que do IPI a pagar devem ser deduzidos os montantes incidentes nas operações anteriores. $^{278}$

Da mesma forma, exemplificando a inconsistência dos partidários da distinção forte, muito difundida na doutrina do direito tributário, Ávila lembra que há autores que, apesar de definirem os princípios como normas de estrutura diferenciada, cujo conflito seria solucionável por meio da ponderação, insistem em chamar de princípios normas não sujeitas à

Dworkin e Alexy, pois “após a interpretação em sentido estrito, uma regra jurídica é já subsumível, enquanto que os princípios ainda poderão entrar em colisão com outros princípios, exigindo-se, nesse caso, que se proceda a um sopesamento para harmonizá-los”. Princípios e regras: mitos e equívocos acerca de uma distinção cit., p. 617.

276 ÁVILA, Humberto. Teoria dos princípios cit., p. 181.

277 O autor acrescenta, ainda, que, ao lado das regras e dos princípios, figuram os postulados, que ditam os critérios de aplicação dos primeiros; são normas metódicas, que estruturam a aplicação das regras e dos princípios; são, numa síntese, as condições essenciais para apreensão do direito como objeto cultural. Divide-os em dois grupos: o dos postulados específicos, dependentes de certos critérios e elementos, e, por oposição, o dos postulados inespecíficos, quando não se refiram a nenhum elemento ou critério. Dentre os postulados específicos, que são aqueles que interessam ao presente estudo, arrola o da igualdade, que requer dois sujeitos, um critério de discrímen e uma finalidade; o da razoabilidade, que se condiciona à existência de conflitos entre o geral e o individual, entre a norma e a realidade ou entre o critério e a medida; e o da proporcionalidade, que demanda uma relação de causalidade entre um fim e um meio (idem, ibidem, p. 143).

278 Teoria dos princípios cit., p. 86. 
flexibilização em decorrência de outros princípios, tal a não-cumulatividade, que permite deduzir, do imposto a pagar, o montante incidido nas operações anteriores. ${ }^{279}$

Tanto na distinção fraca como na forte, as consequências são nefastas: "na primeira, haverá aplicação com alto grau de subjetividade em função da elevada abertura da norma; na segunda, haverá uma ponderação que irá atribuir um peso aos princípios colidentes no caso concreto [...]”. Essas inconsistências "provocam um resultado normativo indesejado: a flexibilização da aplicação de uma norma que deveria ser aplicada com maior rigidez. O tiro sai pela culatra [...]”. 280

Na dissociação inclusiva proposta pelo autor, dependendo da perspectiva adotada, o comportamento descrito num dado dispositivo tanto poderá ser regra como poderá ser princípio.

\subsubsection{Não-cumulatividade do IPI e do ICMS: o princípio e a regra}

Apreciar a não-cumulatividade sob o ponto de vista da argumentação de justiça implica relacioná-la - e interpretá-la - como concretizadora de diversos fins. Se, de acordo com Humberto Ávila, é possível vislumbrar no mesmo dispositivo tanto o princípio como a regra, vejamos as perspectivas possíveis para a não-cumulatividade do IPI e do ICMS.

3.5.2.1 Os princípios relacionados à não-cumulatividade dos tributos brasileiros sobre vendas/consumo

\subsection{Não-cumulatividade e capacidade contributiva}

Klaus Vogel registra que, historicamente, a ideia de capacidade contributiva aparece, no contexto da doutrina da justificação dos tributos, associada à teoria do sacrifício. ${ }^{281}$

\footnotetext{
279 Idem, ibidem, p. 89.

280 ÁVILA, Humberto. A teoria dos princípios e o direito tributário. Revista Dialética de Direito Tributário, $\mathrm{n}$. 125, p. 33-49, especialmente p. 39, São Paulo: Dialética.

281 VOGEL, Klaus. Tributação da renda mundial. Cadernos de direito tributário e finanças públicas, v. 2, n. 7, p. 133-43, especialmente p. 134, São Paulo: Revista dos Tribunais, abr-jun. 1994.
} 
A teoria do sacrifício surgiu como contraponto à teoria do benefício, segundo a qual os tributos eram devidos ao Estado em contrapartida aos benefícios prestados à comunidade. O valor a pagar, de acordo com a teoria do benefício, deveria ser calculado conforme a vantagem extraída pelos indivíduos das atividades estatais. ${ }^{282}$ Tal teoria mostrou-se inadequada pois, in extremis, levava à iniquidade de compelir a parcela da população de mais baixa renda - que mais precisa e, portanto, mais extrai benefícios dos serviços estatais - a uma contribuição maior que a devida pelos mais ricos.

Surgiu então a ideia do sacrifício: todos deveriam sacrificar-se em prol do Estado, então compreendido como um organismo superior, praticamente deificado. ${ }^{283}$ Nesse sentido, o quantum a pagar aferia-se a partir da capacidade individual de pagamento de cada um. ${ }^{284}$

Por esse viés positivo, a capacidade contributiva atua como instrumento da

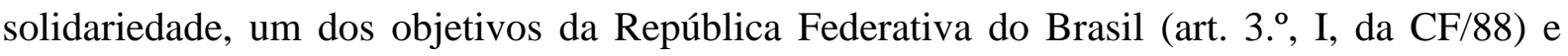
demonstra que o Brasil acompanhou a evolução sobre a "justificativa” da tributação: tributos são devidos em virtude do princípio da solidariedade social.

Assim, aqueles que manifestarem capacidade devem pagar tributos para que o Estado constitua uma sociedade justa e igualitária. Essa a visão de Tipke, citado por Brandão Machado. ${ }^{285}$ Segundo o autor alemão, a capacidade contributiva é um princípio constitutivo (em oposição aos princípios proibitivos, v.g., o da vedação ao confisco).

Mas a capacidade contributiva também pode ser analisada sob o viés negativo, traduzindo a preocupação do legislador constituinte em proteger outros valores assegurados constitucionalmente, como a propriedade e a livre iniciativa. ${ }^{286}$ Sob esse aspecto, finca-se nas

282 SCHOUERI, Luis Eduardo. Normas tributárias indutoras e intervenção econômica. São Paulo: Forense, 2005. p. 138. O autor relata também que outra teoria, a da equivalência, preconizava que o valor do tributo deveria corresponder ao custo das atividades necessárias à proteção da pessoa e de seu patrimônio.

283 VOGEL, Klaus. Tributação da renda mundial cit., p. 134.

284 SCHOUERI, Luis Eduardo. Imposto de Renda e o comércio eletrônico. In: ; COSTA, Alcides Jorge (Coord.). Direito tributário atual. São Paulo: Dialética, 2001. v. 16, p. 146-160, especialmente p. 155. O autor ressalta que a crítica a essa teoria foi não explicar por que um contribuinte deveria sacrificar-se mais que o outro, pagando mais tributos.

285 TIPKE, Klaus. Princípio de igualdade e idéia de sistema no direito tributário. In: MACHADO, Brandão (Coord.). Direito tributário. Estudos em homenagem ao Prof. Ruy Barbosa Nogueira.

286 O equilíbrio entre um viés e outro pode ser encontrado no princípio da proporcionalidade, pressuposto do texto constitucional brasileiro. Sobre a proporcionalidade entre o viés positivo e o negativo da capacidade 
dobras de outros princípios, como o da renda líquida (capacidade contributiva do ponto de vista objetivo, ou absoluta ${ }^{287}$ ) e o da manutenção do mínimo existencial (capacidade contributiva do ponto de vista subjetivo, ou relativa). ${ }^{288}$

A definição do que sejam os aspectos absoluto (ou objetivo) e relativo (ou subjetivo) da capacidade contributiva não é uniforme na doutrina.

Paulo Caliendo ${ }^{289}$ diz que no aspecto absoluto a capacidade contributiva deve ser entendida como o aumento progressivo que a carga tributária deve ter tanto no plano vertical, ou seja, na proporção do incremento da riqueza tributável, como no horizontal, isto é, tributando igualmente contribuintes com a mesma capacidade econômica. Já o aspecto relativo ou subjetivo da capacidade contributiva significa que o encargo tributário deve corresponder à situação de cada contribuinte.

A nosso ver, as duas perspectivas propostas por Paulo Caliendo traduzem o que chamamos de viés negativo da capacidade contributiva, que a vislumbra como critério de graduação da tributação.

Sobre a capacidade contributiva como limite e critério de graduação dos tributos escreveu José Marcos Domingues de Oliveira. ${ }^{290}$ Para esse autor, a capacidade contributiva, no sentido absoluto, é o próprio pressuposto de fato da tributação, a riqueza tributável; e, no sentido relativo, é a parcela da riqueza individual que será alcançada pela tributação.

contributiva, cf. PONTES, Helenilson Cunha. O principio da proporcionalidade e o direito tributário brasileiro: hipóteses de aplicação. Tese (Doutorado). São Paulo (USP), 1999.

${ }^{287}$ Cf. DERZI, Misabel de A. M. In: BALEEIRO, Aliomar Limitações constitucionais ao poder de tributar cit., p. 692.

${ }^{288}$ Idem, ibidem, p. 693. O critério pessoal, nos impostos ditos diretos, é facilmente implementado por meio de diferenciação de alíquotas ou deduções de base, por exemplo. Nos impostos designados indiretos, tais o ICMS e o IPI, a pessoalidade se efetiva por intermédio da seletividade, graduando-se as alíquotas de acordo com a essencialidade do tributo.

${ }^{289}$ Cf. CALIENDO, Paulo. A Cofins nas instituições financeiras: da aplicação do princípio da neutralidade fiscal. PIS - Cofins: questões atuais e polêmicas. São Paulo: Quartier Latin, 2005, p. 300-301.

290 OLIVEIRA, José Marcos Domingues de. Capacidade contributiva. Rio de Janeiro: Renovar, 1998. p. 36. No mesmo sentido, Luis Eduardo Schoueri, diz que se pode vislumbrar, na capacidade contributiva, tanto um limite para a graduação da tributação como um parâmetro para distinguir situações tributáveis de outras não tributáveis (Normas tributárias indutoras e intervenção cit., p. 282). 
Dito isto e, à vista do quanto dissemos anteriormente a respeito da tributação sobre vendas/consumo, julgamos apropriado concluir que a não-cumulatividade se relaciona de perto com o princípio da capacidade contributiva, analisado tanto sob o viés positivo (absoluto ou objetivo) como do negativo (subjetivo ou relativo). ${ }^{291}$

Se a tributação sobre vendas/consumo, na modalidade plurifásica não-cumulativa, faz com que, juridicamente, o encargo tributário seja repassado aos consumidores, desonerando os sujeitos econômicos; se os tributos sobre vendas/consumo não-cumulativos equivalem a uma tributação indireta sobre a renda cujo parâmetro é o consumo familiar; se o consumo é medida mais adequada que o patrimônio para aferir a capacidade do indivíduo participar do custeio das atividades estatais - então a não-cumulatividade viabiliza que o tributo sobre vendas/consumo alcance a riqueza do consumidor, ou seja, sua capacidade contributiva sob o viés positivo.

Por outro lado, se a distorção nos preços causada pela tributação plurifásica em cascata, que onera o consumidor mais do que seria desejável, foi uma das razões que levaram os franceses a criar (e a maioria dos países da Europa e Américas a adotar) regimes nãocumulativos para a tributação sobre vendas/consumo, então a não-cumulatividade descreve o comportamento necessário à promoção gradual da tributação conforme a capacidade contributiva do consumidor (capacidade contributiva sob o viés negativo).

Pelo primeiro critério distintivo proposto por Humberto Ávila, a perspectiva da nãocumulatividade como regra se manifesta na descrição do dever do contribuinte de abater o imposto incidente nas etapas anteriores, destacar o imposto na nota fiscal e, com isso, desonerar (juridicamente) o empreendimento econômico, implementando a tributação indireta da renda conforme a capacidade contributiva do consumidor (descrição imediata do comportamento necessário para atingir determinado fim). A perspectiva de princípio decorre

291 I.e, à pessoalidade da tributação, igualmente exigida pela Constituição (art. 145, § 1. ${ }^{\circ}$ ). Noção igualmente associada à capacidade contributiva é a de progressividade. É bem verdade que, a princípio, a noção de capacidade contributiva remetia menos à ideia de progressividade e mais à de proporcionalidade, constituindo esse último, um critério que atendia plenamente aos interesses do Estado Liberal, ao qual desagradava a ideia de que a tributação pudesse servir de instrumento de intervenção na economia. Todavia, por não contribuir para a redução das desigualdades, a tributação meramente proporcional não se coaduna com o atual Estado Democrático de Direito, síntese do Estado de Direito e o Estado Social, e que se pauta pela solidariedade e pela busca da justiça social. A tributação progressiva - assim como a coibição da elisão e evasão fiscais - é conceito que melhor se amolda às perspectivas do Estado de Direito porque propicia redistribuição da renda. 
do dever imposto à Administração de aceitar o creditamento, ainda que extemporaneamente e sempre com correção monetária, como meio para realizar a tributação conforme a capacidade contributiva (comportamento mediato, visando a realização do estado ideal das coisas) ${ }^{292}$.

No segundo critério, a dimensão de regra é confirmada quando o contribuinte deduz do valor de IPI e ICMS, a pagar num dado período, o valor correspondente aos créditos relativos aos impostos incidentes sobre as operações de entradas naquele mesmo período. Nesse momento, dá-se a correspondência (subsunção) entre o fato (situação factual hipotética), a norma (à hipótese descrita na norma) e a finalidade; em virtude da adoção desse comportamento o tributo onerará o consumidor final (dimensão axiológica mediata). A dimensão principiológica decorre da avaliação de que aceitar o creditamento extemporâneo com correção monetária contribui para a realização da tributação conforme a capacidade contributiva (a conduta mediata produz o efeito de realizar o estado de coisas ideal).

Aplicando-se o terceiro critério, verifica-se que, ao decidir caso específico sobre o tema não-cumulatividade, o juiz julgará imprestáveis os registros fiscais de uma empresa que não tenha observado as regras de abatimento por período, confundindo débitos de um período com créditos de outro, e sancionará a aplicação de multa formal, por ter sido descumprida a regra da não-cumulatividade; porém, ao apreciar o valor do imposto a pagar, levará em consideração o princípio da não-cumulatividade como realizador da capacidade contributiva e deverá decidir pelo direito ao creditamento extemporâneo e à respectiva correção monetária.

\subsection{Não-cumulatividade e neutralidade}

Quando tratamos da evolução histórica dos tributos sobre vendas/consumo, dissemos que a técnica não-cumulativa foi desenvolvida para contornar diversos problemas econômicos, entre os quais onerar indevidamente os empreendimentos econômicos - o que induzia à concentração de empresas, prejudicial à concorrência - e distorcer os preços, igualmente prejudicial à concorrência, por interferir nos hábitos de consumo.

Sob o viés tradicional a neutralidade preconiza que a tributação interfira o mínimo possível no comportamento dos agentes econômicos. Remete, portanto, à função arrecadatória

\footnotetext{
${ }^{292}$ Confira-se, exemplificativamente, o RE 212.163, julgamento em 18-02-2002, DJU de 26.04.2002.
} 
da norma tributária - que não é a única, como ensina Alcides Jorge Costa, relembrando Musgrave: "qualquer sistema tributário tem uma função alocativa, uma função estabilizadora da economia e uma função redistributiva”, ${ }^{293}$ às quais o professor acrescenta a função de promover o desenvolvimento econômico. Além disso, como visto anteriormente, qualquer tributo sempre interferirá na composição dos preços; jamais será inteiramente neutro.

Ao que se infere, foram essas as razões que levaram Ricardo Lobo Torres a afirmar que a neutralidade é princípio mais de natureza econômica que propriamente tributária. ${ }^{294}$

De fato, um dos valores prestigiados pela neutralidade da tributação e que justifica seu tratamento como princípio é a livre concorrência, indicada nominalmente na CF/88, ${ }^{295}$ no título que trata da ordem econômica e financeira, mais precisamente no capítulo que aborda os princípios gerais da atividade econômica.

Mas isso não afasta a neutralidade do campo do direito tributário porque, como explica Paulo Caliendo, esse princípio busca, por intermédio da tributação, encontrar a correta relação entre o contribuinte e a ordem pública econômica; entre a tributação e a eficiência dos agentes econômicos; entre a tributação no sentido privado e a tributação no contexto econômico e social. ${ }^{296}$ Relaciona-se, portanto, com o valor igualdade na tributação.

Já Fernando A. Zilveti afirma que a não-cumulatividade é regra que realiza o princípio da neutralidade, prestigiando as leis (econômicas) da livre concorrência e da competitividade. $^{297}$

293 Algumas idéias sobre uma reforma do sistema tributário brasileiro. In: NOGUEIRA, Ruy Barbosa (Coord.). Direito tributário atual. São Paulo: Resenha Tributária, 1987. v. 7/8, p. 1.733 a 1.770 (1753).

294 O IVA no direito comparado cit., p. 160.

295 “Art. 1. ${ }^{\circ}$ A República Federativa do Brasil, formada pela união indissolúvel dos Estados e Municípios e do Distrito Federal, constitui-se em Estado Democrático de Direito e tem como fundamentos: IV - os valores sociais [...] da livre iniciativa.”. “Art. 170. A ordem econômica, fundada na valorização do trabalho humano e na livre iniciativa, tem por fim assegurar a todos existência digna, conforme os ditames da justiça social, observados os seguintes princípios: [...] IV - livre concorrência.”

296 A Cofins nas instituições financeiras... cit., p. 297.

${ }^{297}$ Variações sobre o princípio da neutralidade no direito tributário internacional. Direito Tributário Atual, n. 19, p. 33, São Paulo: Dialética e IBDT, 2005. No mesmo tom, confira-se: PINTO, Miguel Silva. O combate à fraude ao Imposto sobre o valor acrescentado: um desafio para a União Européia. IVA para o Brasil Contributos para a Reforma da Tributação do Consumo. Belo Horizonte: Fórum, 2007, p. 603. 
Dissertando sobre a neutralidade da tributação, José Luis R. Brazuna ${ }^{298}$ relata que Luis Eduardo Schoueri vislumbra a neutralidade tributária não como a absoluta ausência de interferência do Estado na ordem econômica por meio da tributação, mas como princípio que preconiza o uso da tributação com a finalidade de corrigir deficiências das leis de mercado, realizando os objetivos da ordem econômica. Nesse sentido, José Luis Brazuna conclui que o art. 146- $\mathrm{A}^{299}$ da CF/88 explicita o princípio da neutralidade tributária (a nosso ver, sob o viés relativo).

Ousamos divergir. Entendemos que o princípio da neutralidade tributária traduz a neutralidade concorrencial, isto é, a ausência de intervenção da tributação no mercado. É nosso entendimento, também, que a promoção do equilíbrio concorrencial via desestímulo à integração vertical verificada nos tributos plurifásicos não-cumulativos (ou sobre o valor agregado) é consequência natural da adoção da referida técnica não-cumulativa. Nesse sentido, ao estipular que um tributo incidente sobre a circulação de riquezas será arrecadado via sistemática não-cumulativa, o que se tem é a harmonização do tributo à técnica de arrecadação mais racional (justamente porque atende à neutralidade concorrencial), e não uma intervenção do estado no mercado via norma tributária extrafiscal ou indutora - isso, a nosso ver, é o que está previsto no art. 146-A da CF/88: intervenção na economia, ou seja, a antítese da neutralidade.

Pois bem. Na linha argumentativa de Humberto Ávila, a não-cumulatividade poderia ser vista como regra porque, nos tributos sobre a circulação de riquezas, é compensando o tributo pago nas operações anteriores que se transfere, aos bens e serviços, um tributo proporcional ao efetivo valor daqueles bens e serviços, independentemente do número de operações antecedentes no ciclo econômico (ou seja, os dispositivos da não-cumulatividade do IPI e do ICMS descrevem, nesse sentido, um comportamento imediato e o sujeito passivo deve realizar o dever ali prescrito, promovendo a correlação entre o fato, a norma e a sua finalidade). A determinação constitucional de que o IPI e o ICMS serão arrecadados de forma não-cumulativa, qualquer que seja o sujeito passivo, demonstra seu viés de princípio, que

298 Neutralidade tributária e uso da tributação para prevenir desequilíbrios da concorrência. 2008. Dissertação (Mestrado). São Paulo - USP, p. 171.

299 “Art. 146-A. Lei complementar poderá estabelecer critérios especiais de tributação, com o objetivo de prevenir desequilíbrios da concorrência, sem prejuízo da competência de a União, por lei, estabelecer normas de igual objetivo." 
assegura a neutralidade do tributo e a igualdade (no sentido de isonomia) entre os agentes econômicos (não-cumulatividade, nessa avaliação, é o comportamento mediato, que estabelece à Administração o dever de realizar o estado das ideal das coisas).

Ao decidir um caso concreto, o juiz adotará a não-cumulatividade na perspectiva de regra ao determinar que do saldo de IPI a ser pago por um determinado sujeito passivo sejam abatidos os créditos relativos às aquisições do mesmo período; mas a subscreverá como um princípio quando determinar que, em operações de exportação, em que não incide o IPI, seja mantido o crédito relativo às aquisições, sem necessidade de estorno, como forma de manter a neutralidade da tributação, de forma que o empreendedor nacional não seja prejudicado com a majoração do custo de seu produto, em face dos empreendedores estrangeiros.

Esse exemplo remete ao relacionamento entre a não-cumulatividade e a tributação no país de destino, para nós, corolário da neutralidade.

\subsection{Não-cumulatividade e país de destino}

Dizer que a tributação deve observar o princípio do país de destino significa que bens ou mercadorias remetidos ao exterior devem sofrer incidência apenas no país onde serão consumidos.

De acordo com Ricardo Lobo Torres, ${ }^{300}$ o princípio do país de destino, na vertente da exportação, opera-se pela isenção na operação de remessa da mercadoria ou serviço ao exterior e, ainda, pela anulação das incidências anteriores à exportação, ou por sua cobrança e restituição dos valores pagos nas etapas da circulação econômica que antecedem a remessa ao estrangeiro. Na vertente da importação, opera-se pela incidência de um imposto que seja capaz de aproximar o preço da mercadoria importada àquela produzida internamente.

300 O IVA no direito comparado cit., p. 161. 
No mesmo sentido, Marcos Valadão sustenta que, ao adotar o princípio do destino, um país importador tributará seus bens e serviços importados; já um país exportador não os tributará. $^{301}$

A relação entre a não-cumulatividade e o princípio do destino vem explicitada por Carl Shoup quando afirma que, sob o princípio de destino, um tributo sobre o valor agregado do tipo imposto contra imposto assegurará a isenção total da exportação se (i) a cadeia de créditos e débitos não for quebrada e (ii) houver reembolso ao exportador do tributo incidente na última etapa de circulação (ou seja, a exportação) ou se for permitido ao exportador manter o crédito oriundo dessa operação e abatê-lo contra débitos relativos a outras operações internas. $^{302}$

Ainda conforme Ricardo Lobo Torres, o princípio do destino se inspira na ideia de justiça e de capacidade contributiva: sendo o consumo uma manifestação de capacidade econômica, o tributo deve ser pago por aquele que consome o bem.

Clotilde Celorico Palma ${ }^{303}$ relata que, na expectativa de atingir o modelo federalista, a União Europeia fala, desde a Primeira Diretiva, ${ }^{304}$ na adoção da tributação conforme o princípio da origem, tendo a tributação de destino sido estabelecida apenas transitoriamente. Segundo a autora, o princípio da origem foi preconizado por Maurice Lauré, por entender que o IVA deveria ser (i) calculado na origem, pelas alíquotas praticadas no país de destino, (ii) pago no país de origem e, oportunamente, (iii) transferido para o país de destino, por meio de câmaras de compensação. ${ }^{305}$

${ }^{301}$ Comparative analysis of the Value Added Tax (VAT) and Retail Sales Tax (RST): a contribution to tax reform studies in the U.S., IVA para o Brasil - Contributos para a Reforma da Tributação do Consumo. Belo Horizonte: Fórum, 2007 p. 390.

302 SHOUP, Carl. Value Added Taxation in Developing Countries. Washington: Malcolm Gillis, Carl S. Shoup, Gerardo P. Sicat, [s.d.]. p. 8-9.

303 A harmonização comunitária do imposto sobre o valor acrescentado: quo vadis? IVA para o Brasil Contributos para a Reforma da Tributação do Consumo. Belo Horizonte: Fórum, 2007, p. 207.

304 Implicitamente, ao referir-se, no art. 4. ${ }^{\text {}}$, à supressão da tributação na importação e ao desagravamento da exportação.

305 Tributar as exportações ocorridas entre os países membro de uma comunidade econômica origem é viável se existir entre os seus membros consenso sobre a compensação; caso contrário, ou seja, na inexistência de consenso ou quando as operações de exportação se realizem entre países não partícipes de uma mesma comunidade econômica, a tributação no destino é mais adequada. 
José Xavier Basto, ao explicar o regime transitório adotado no IVA europeu, assevera que, (i) quando as operações ocorrem "no espaço nacional”, compreendido nas fronteiras de cada Estado-membro, as operações são tributadas na origem; mas quando se está diante (ii) do denominado "espaço exterior”, onde se processam as transações entre os Estados-membros da União Europeia e os Estados não-membros, e (iii) do "espaço intracomunitário”, em que se verificam os negócios entre Estados-membros e, neste último, ocorrendo a transação entre sujeitos passivos, “a regra é a tributação no destino”, 306

Dessa análise chegamos à conclusão de que a não-cumulatividade, no que respeita à tributação conforme o país de destino, associa-se a outros mecanismos, deles dependendo para atingir o estado ideal das coisas, que é a neutralidade da tributação. Nesse sentido, apresenta características de princípio, pois descreve a adoção de comportamentos que, mediatamente, visam concretizar a isonomia. Daí afirmarmos tratar-se de corolário da neutralidade. Na União Europeia isso se verifica claramente na pretensão, ressaltada por Alessandra Martins, ${ }^{307}$ de que a tributação do IVA se dê conforme as características de um mercado interno, ou seja, que o tributo não interfira na concorrência entre os agentes econômicos dos países-membros: seja neutro.

$\mathrm{Na}$ perspectiva de regra, a não-cumulatividade revela "procedimento racional de fundamentação" que permite “especificar as condutas necessárias à realização dos valores por eles prestigiados quanto justificar e controlar sua aplicação”. ${ }^{308}$ Essas condutas são a manutenção da cadeia de créditos e débitos e o ressarcimento do tributo pago pelo exportador.

${ }^{306}$ A adopção do sistema comum europeu de Imposto sobre o Valor Acrescentado (IVA) em Portugal. IVA para o Brasil - Contributos para a Reforma da Tributação do Consumo. Belo Horizonte: Fórum, 2007, p. 113 (destaques nossos). Quando a transação se der no "espaço intracomunitário", mas entre um sujeito passivo e um não sujeito passivo, a regra é a da origem, caracterizando o que se tem chamado de "regime transitório do IVA para as transações intracomunitárias”, que é do tipo misto.

307 MARTINS, Alessandra. A admissibilidade de uma cláusula geral antiabuso em sede de IVA. IVA para o Brasil - Contributos para a Reforma da Tributação do Consumo. Belo Horizonte: Fórum, 2007, p. 274.

308 ÁVILA, Humberto. Teoria dos princípios cit., p. 64. 


\section{A NÃO-CUMULATIVIDADE DO PIS E DA COFINS}

\subsection{Breve histórico legislativo da não-cumulatividade do PIS e da Cofins}

As Leis 10.637/2002 e 10.833/2003, que instituíram a não-cumulatividade do PIS e da Cofins, foram fruto de conversão das Medidas Provisórias 66/2002 e 135/2003.

Nas exposições de motivos daquelas medidas provisórias, o Governo Federal deixou claro que pretendia dar continuidade à reestruturação da forma de arrecadação das contribuições sobre o faturamento, iniciada com a instituição de cobrança monofásica para diversos setores. ${ }^{309}$ Os objetivos literalmente consignados eram

corrigir distorções relevantes decorrentes da cobrança cumulativa do tributo, como, por exemplo, a indução a uma verticalização artificial das empresas, em detrimento da distribuição da produção por um número maior de empresas mais eficientes - em particular empresas de pequeno e médio porte, que usualmente são mais intensivas em mão de obra. ${ }^{310}$

e favorecer o produto nacional, possibilitando sua "maior competitividade [...] uma vez que os bens importados, por não terem incidência anterior, não geram direito a crédito, ao mesmo tempo em que as exportações são desoneradas”. 311

A premissa de que o nível de arrecadação não seria afetado também ficou clara, quando o Governo expôs que as alterações nas referidas contribuições implicariam, “necessariamente, a redistribuição da carga tributária entre os setores”. 312

309 Autorizada pela inclusão do $\S 4 .^{\circ}$ no art. 149 da CF/88, dispondo que “a lei definirá as hipóteses em que as contribuições incidirão uma única vez”.

310 Cf. item 1.1 da Exposição de Motivos da MP 135/03. No item 2 da Exposição de Motivos da MP 66/2002 ficou consignado que "a proposta [...] dá curso a uma ampla reestruturação na cobrança das contribuições sociais incidentes sobre o faturamento. Após a instituição da cobrança monofásica em vários setores da economia, o que se pretende, na forma desta Medida Provisória, é, gradualmente, proceder-se à introdução da cobrança em regime de valor agregado - inicialmente com o PIS/Pasep para, posteriormente, alcançar a Contribuição para o Financiamento da Seguridade Social (Cofins).”.

311 Cf. item 4 da Exposição de Motivos da MP 135/03.

312 Cf. itens 4 das Exposições de Motivos de ambas as medidas provisórias. 
Em 19.12.2003, quando já vigiam as referidas medidas provisórias, foi promulgada a EC 42/2003, que incluiu, no art. 195, o § 12 com o seguinte teor: “a lei definirá os setores de atividade econômica para os quais as contribuições incidentes na forma dos incisos I, b; e IV do caput, serão não-cumulativas”.

A nosso ver, essa inserção da não-cumulatividade no texto constitucional decorreu do receio de que o regime fosse impugnado judicialmente - afinal, se a premissa era manter o nível de arrecadação, os contribuintes prejudicados com a redistribuição da carga tributária poderiam questionar se o legislador ordinário teria poderes para referida quebra de isonomia. $^{313}$

A mesma EC 42/2003 trouxe outras inovações ao texto constitucional que guardam pertinência com o objeto de nosso estudo:

(i) acrescentou ao art. 195 o $\S 13$, em cujos termos "aplica-se o disposto no $\S 12$ inclusive na hipótese de substituição gradual, total ou parcial, da contribuição incidente na forma do inciso $\mathrm{I}$, a, pela incidente sobre a receita ou o faturamento";

(ii) incluiu o art. 146-A, dizendo que "lei complementar poderá estabelecer critérios especiais de tributação, com o objetivo de prevenir desequilíbrios da concorrência, sem prejuízo da competência de a União, por lei, estabelecer normas de igual objetivo";

313 Doutrina recente afirma que "a inserção no texto constitucional da não-cumulatividade mostra-se em duas vias: uma em virtude da falta de técnica legislativa e do receio de inúmeras demandas judiciais, sob a alegação de que não havia comando constitucional que autorizasse a não-cumulatividade das contribuições, uma vez que sua existência fazia-se sob a forma de princípio. A outra, pela falta de respeito ao texto Constitucional brasileiro, cujos valores estão deturpados. Se uma ação é inconstitucional, muda-se a Constituição". SANT’ANNA, Carlos Soares. A sistemática do PIS e da Cofins não-cumulativos para as empresas de extração mineral (p. 725-740), PIS-Cofins: questões atuais e polêmicas. São Paulo: Quartier Latin, 2005, p. 729. Conforme relato de Ives Gandra M. Silva, o então presidente da Comissão de Reforma Tributária da Câmara e deputado Germano Rigotto afirmou que o Governo preferiu inserir a nãocumulatividade das contribuições na Constituição porque caso o fizesse por meio de legislação ordinária, o sistema poderia ser mais facilmente revogado, sem apresentar nenhum outro argumento de peso (Nãocumulatividade do PIS e da Cofins - Implicações contábil, societária e fiscal. São Paulo: Quartier Latin, 2007. p. 71). 
(iii) inseriu, no $\S 2 .^{\circ}$ do art. 149 , que trata das contribuições sociais e de intervenção no domínio econômico, o inc. II, dispondo que referidos tributos poderiam incidir “também sobre a importação de produtos estrangeiros ou serviços”. Mais adiante, deixou claro que as contribuições que incidiriam sobre a exportação e a importação seriam as sociais, de seguridade social, pois adicionou, ao art. 195, o inc. IV prevendo que também financiará a seguridade social o importador de bens ou serviços do exterior, ou quem a ele a lei equiparar;

Posteriormente, o § 9. ${ }^{\circ}$ do art. 195 da CF/88 - que já previa que as contribuições de seu inciso I, incidentes sobre o lucro, o faturamento ou a receita, poderiam ter alíquotas e bases de cálculo diferenciadas em razão da atividade econômica ou da utilização intensiva de mão-de-obra - foi alterado pela EC 47/2005, passando a dispor que tais diferenciações poderiam dar-se também em virtude do porte da empresa ou da condição estrutural do mercado de trabalho.

Os questionamentos que se seguiram eram inevitáveis: o fato de serem arrecadados por meio de técnica não-cumulativa teria transformado o PIS e a Cofins (não-cumulativos) em tributos sobre vendas/consumo? Teria a não-cumulatividade do PIS e da Cofins o mesmo significado da não-cumulatividade do IPI e do ICMS? Tributos incidentes sobre a receita podem ser não-cumulativos? Haveria um significado único de não-cumulatividade no texto constitucional? Teria a não-cumulatividade do PIS e da Cofins status constitucional? Como se opera a não-cumulatividade do PIS e da Cofins (qual o método de cálculo)? Que são insumos para PIS e Cofins não-cumulativos? Poderia a lei eleger outros fatores de discrímen, além do setor de atividade econômica? O setor de atividade econômica é um fator de discrímen legítimo?

\subsection{PIS e Cofins não-cumulativos e a translação jurídica do encargo tributário}

Sendo o PIS e a Cofins tributos incidentes sobre a receita total - que inclui as receitas de vendas - e, considerando que sua arrecadação se dá de forma não-cumulativa mecanismo que visa carrear o encargo jurídico do tributo ao consumidor final -, vejamos se as referidas contribuições seriam tributos sobre vendas/consumo. 
Se, como vimos anteriormente, tributos sobre o consumo são aqueles cujo encargo jurídico é trasladado para o consumidor final, para saber se o PIS e a Cofins não-cumulativos poderiam ser designados como tais, é preciso verificar se seu pressuposto de fato e seu fato gerador se coadunam com a repercussão jurídica.

Como examinamos anteriormente, o IPI e o ICMS tributam a circulação de riquezas em suas fases elementares; seus pressupostos de fato são as operações por meio das quais se dá aquela circulação de riqueza, ou seja, as operações de produção e distribuição em que a riqueza produzida é direcionada ao consumo. As contrapartidas dessas operações, isto é, as receitas auferidas com as mencionadas operações, são irrelevantes tanto para a configuração dos respectivos fatos geradores como para a formação das respectivas obrigações tributárias. Consumadas as operações, reputam-se devidos aqueles impostos.

O PIS e a Cofins cumulativos (da Lei 9.718/98) também tributam a circulação de riquezas, mas sua materialidade econômica é a receita bruta proveniente das operações de venda de mercadorias e serviços (o faturamento, compreendido em sua noção corrente). Já o PIS e a Cofins não-cumulativos (Leis 10.637/2002 e 10.833/2003), que interessam ao nosso estudo, tributam igualmente a circulação de riquezas, só que numa perspectiva mais ampla. Sua materialidade econômica é a receita total auferida pela pessoa jurídica, assim entendida como o ingresso patrimonial instantâneo e em caráter definitivo, que remunera as operações de venda de mercadorias e serviços, os investimentos e a cessão onerosa e temporária de bens e direitos a terceiros.

Apesar de terem em comum a fonte econômica tributável - a circulação de riquezas -, referidos impostos (IPI e ICMS) e contribuições (PIS e Cofins, cumulativos e nãocumulativos) têm pressupostos de fato/materialidades econômicas distintos.

Para as operações de produção e distribuição gravadas pelo IPI e pelo ICMS, é necessário existir, além do produtor/vendedor, um terceiro (o adquirente), sem o qual a operação de direcionamento do bem ou serviço ao consumo não se completa. Por isso, diz-se que o pressuposto de fato desses impostos é bilateral. 
Já a receita, que é materialidade do PIS e da Cofins, ${ }^{314}$ não requer essa dualidade de sujeitos. Economicamente, pode-se vislumbrar certo caráter sinalagmático, porque a receita auferida por determinada pessoa equivale ao dispêndio realizado por outra. Nem poderia ser diferente, pois, como vimos no item 1.2.1, na circulação econômica, que delineia a fonte tributável circulação de riquezas haverá sempre duas pessoas e um bem. Mas essa dualidade diz com as operações de circulação econômica, as quais dão origem às receitas - essas sim objeto do PIS e da Cofins. As operações são uma das materialidades compreendidas naquela fonte tributável, as receitas são outra.

Para configurar a receita, basta a perspectiva de quem a aufere, pois ela é o ingresso em caráter definitivo no patrimônio da pessoa jurídica, aferido instantaneamente de que falou José Antônio Mintael. Ou, como explica Marco Aurélio Greco, a "receita é auferida por alguém. Nisto se esgota a figura”. ${ }^{315}$

A presença do terceiro (adquirente/consumidor), essencial à conformação do pressuposto de fato do IPI e do ICMS, não é relevante para a configuração da receita, materialidade econômica alcançada pelo PIS e pela Cofins cumulativos e não-cumulativos.

Em outras palavras, assim como o patrimônio afere-se a partir da perspectiva de quem é proprietário, a receita é realidade apreensível a partir do ponto de vista do indivíduo que a recebe. A existência de outro indivíduo que entrega a receita àquele que a aufere não é relevante para o conceito jurídico de receita; é dado econômico.

Como não há, na materialidade econômica do PIS e da Cofins não-cumulativos, nenhuma relação transacional envolvendo uma dualidade de sujeitos, o fato de serem

314 Cumulativos e não-cumulativos, com a distinção de, nos primeiros, restringir-se à receita advinda da venda de mercadorias e serviços.

315 Não-cumulatividade no PIS e na Cofins cit., p. 101. Ricardo Mariz de Oliveira, por fundamento diverso, chega à mesma conclusão. Para aquele autor, "há uma distinção entre os tributos que gravam coisas ou atos relacionados a coisas, e aqueles cujos suportes fáticos não se ligam necessariamente a coisas propriamente ditas”, Entre os tributos nos quais “uma coisa integra de alguma maneira o fato gerador”, arrola o IPI, o ICMS, o IPTU e o ITBI, destacando que os primeiros têm incidência plurifásica, que o ITBI tem incidência única (pois cada ato de alienação é autônomo e distinto dos demais) e que o IPTU tem incidência múltipla, mas não plurifásica, pois seu fato gerador se repete a cada período temporal, mas se refere a um imposto sobre a propriedade e não sobre a circulação; dentre os tributos "independentes de coisas", classifica o PIS e a Cofins, pois, para incidirem, basta haver a receita, proveniente de qualquer origem, qualquer objeto, independendo da "coisa”. Aspectos relacionados à “não-cumulatividade” da Cofins e da contribuição ao PIS. PIS-Cofins: questões atuais e polêmicas. São Paulo: Quartier Latin, 2005, p. 24-27. 
arrecadados por técnica não-cumulativa não transforma aquelas contribuições em tributos incidentes sobre o consumo porque não será possível estabelecer sua repercussão obrigatória em termos jurídicos. Se há alguma translação do custo tributário do PIS e da Cofins nãocumulativos para o consumidor/adquirente, ela se dá na seara econômica, não na jurídica.

Igor Mauler Santiago e Valter Lobato resumem com precisão as razões que afastam o PIS e a Cofins não-cumulativos dos demais tributos incidentes sobre o consumo ao anunciarem que o art. 195 da CF/88 arrola a empresa como financiadora da Seguridade Social, mas não o consumidor; que o PIS, em seus primórdios, foi instituído para que as empresas financiassem o seguro-desemprego dos trabalhadores, com a clara intenção de fazêlos compartilhar dos ingressos representativos de receitas que revelam capacidade econômicofinanceira das empresas; ${ }^{316}$ que seu fato gerador é auferir receitas, fenômeno unilateral, exclusivo das empresas, e não realizar operações, fenômeno dual tributado pelo IPI e pelo ICMS, que, justamente em virtude da bilateralidade, comporta a inserção da figura do adquirente/consumidor; que sua não-cumulatividade não veio acompanhada da seletividade; e, finalmente, que não há destaque do valor das contribuições nas respectivas notas fiscais. Concluem, por fim, que "permanecem o PIS e a Cofins não-cumulativos buscando a riqueza produzida pela empresa, sua capacidade de contribuir (e não a do consumidor) [...]”. ${ }^{317}$

No mesmo sentido, Ricardo Lobo Torres escreve que o princípio da repercussão obrigatória não vincula a incidência não-cumulativa das demais receitas brutas ou faturamentos da pessoa jurídica porque PIS e Cofins não cumprem itinerário que afete o consumidor final diretamente. ${ }^{318}$

Por outro lado, se a materialidade econômica do PIS e da Cofins não-cumulativos é a receita total, que compreende todas as receitas auferidas pela empresa (excetuadas as

316 O mesmo podemos dizer da Cofins, pois sucedeu a contribuição ao Finsocial, que foi instituída para financiar, com recursos advindos da receita bruta das empresas, investimentos assistenciais diversos, como moradia, saúde e alimentação, cf. DL 1.940/82: “Art. 1. ${ }^{\circ}$ Fica instituída, na forma prevista neste decreto-lei, contribuição social, destinada a custear investimentos de caráter assistencial em alimentação, habitação popular, saúde, educação, justiça e amparo ao pequeno agricultor;”.

317 Análise dos arts. 10, XI, e 15, V, da Lei 10.833/2003 - Manutenção da Cofins e do PIS cumulativos para contratos de consórcio, de construção por empreitada e de fornecimento, a preço determinado, de bens e serviços, celebrados antes de 31 de outubro de 2003. PIS-Cofins: questões atuais e polêmicas. São Paulo: Quartier Latin, 2005 p. 578-579.

318 A não-cumulatividade no PIS/Cofins cit., p. 69. 
exclusões postas nas respectivas leis), ou seja, tanto as receitas provenientes das operações de venda e prestação de serviços como aquelas recebidas em contraprestação pela remuneração de investimentos (v.g., receitas financeiras) e pela cessão onerosa e temporária de bens e direitos a terceiros - tais contribuições não são propriamente tributos incidentes sobre as receitas de vendas (tributos sobre vendas). Seriam, quando muito, "parcialmente” incidentes sobre vendas.

Portanto, em direito tributário, o PIS e a Cofins não-cumulativos não podem ser considerados tributos sobre receitas de vendas nem como tributos sobre o consumo. Todavia, isso não lhes retira o caráter de tributos incidentes sobre a circulação de riquezas, pois essa fonte tributável comporta diversos pressupostos de fato, tais as operações e as receitas daí advindas.

Em economia, dá-se o contrário. Justamente porque oneram a circulação de riquezas (que, em termos econômicos, equivale à tributação da riqueza produzida e consumida), referidas contribuições são consideradas incidentes sobre as vendas e o consumo. ${ }^{319}$ É o que registra estudo do BNDES, segundo o qual

os principais tributos sobre vendas (TV) compreendem: o imposto estadual sobre circulação de mercadorias e, pós-1988, sobre comunicações e transportes (ICM/ICMS); o imposto municipal sobre serviços (ISS); e, na competência federal, os impostos sobre produtos industrializados (IPI), operações financeiras (IOF) e, pré-1988, únicos sobre combustíveis, energia elétrica, minerais, transportes e comunicações (IUs.), as contribuições sociais sobre faturamento (Finsocial/Cofins) e receitas (Pis/Pasep), bem assim o imposto e a contribuição provisórios sobre movimentação financeira (IPMF/CPMF). ${ }^{320}$

\subsection{Inexistência de significado único de não-cumulatividade no texto constitucional}

Tendo em vista que a circulação de riquezas alcançada pelo PIS e pela Cofins não diz respeito exclusivamente a operações e negócios relativos à circulação de bens ou serviços,

319 Cf. Vasco Branco Guimarães, ao tratar do sistema brasileiro de tributação do consumo diz que o PIS e a PIS "são considerados pelos empresários como impostos sobre o consumo", além do IPI, do ICMS e do ISS. A tributação do consumo no Brasil: uma visão européia. IVA para o Brasil - Contributos para a Reforma da Tributação do Consumo. Belo Horizonte: Fórum, 2007, p. 59.

320 Boletim Informe-SF, da Secretaria para Assuntos Fiscais - SF, n. 7, p. 1, de 2000 (destaques nossos). 
alguns autores chegam a afirmar que sequer existiria ciclo econômico a ser considerado para fins da não-cumulatividade das referidas contribuições.

Marco Aurélio Greco diz que "não há - subjacente à noção de receita - um ciclo econômico a ser considerado (posto ser fenômeno ligado a uma única pessoa)”. 321

Fátima Fernandes Rodrigues de Souza sustenta que

tais contribuições não têm por pressupostos de fato um ciclo econômico representado pelo encadeamento de operações ou negócios jurídicos tendo objeto uma coisa, e sim uma realidade ligada única e exclusivamente à pessoa do contribuinte, ou seja, à percepção de receita e faturamento. ${ }^{322}$

Ricardo Mariz de Oliveira entende que não se poderia sequer falar em incidência multifásica dessas contribuições, pois “a hipótese de incidência se resume a cada fato solitário - cada receita auferida -, nada tendo a ver com outros fatos ou com elementos externos ao fato considerado na hipótese de incidência”. ${ }^{323}$

Todavia, é nosso entendimento que PIS e Cofins incidem sobre a circulação de riquezas compreendida em sua acepção ampla, equivalente à noção econômica de circulação, à qual se vincula a ideia de um ciclo econômico (cf. itens 2.2.4 e 2.2.5).

Nesse sentido, entendemos viável que PIS e Cofins sejam cobrados de forma nãocumulativa que, a nosso ver, não é princípio ou técnica ligada exclusivamente a tributos sobre o consumo ou a tributos com pressuposto de fato bilateral; é forma de arrecadação aplicável aos tributos incidentes sobre a circulação de riquezas.

Mas, sendo diferentes seus pressupostos materiais, a não-cumulatividade do PIS e da Cofins não é igual à do IPI e ICMS.

321 Não-cumulatividade no PIS/Pasep e na Cofins cit., p. 103.

322 O princípio da não-cumulatividade. In: MARTINS, Ives Gandra da Silva (Coord.) et al. Pesquisas tributárias - Nova Série - n. 10. O princípio da não-cumulatividade. São Paulo: Centro de Extensão Universitária/Revista dos Tribunais, 2004. p. 257-259.

323 Aspectos relacionados à “não-cumulatividade”... cit., p. 23. 
Embora considere não existir ciclo econômico no âmbito do PIS e da Cofins, Marco Aurélio Greco ${ }^{324}$ também conclui que “a não-cumulatividade de PIS e Cofins é criação puramente legal e possui as características que as leis lhe conferem, não cabendo um transplante para PIS e Cofins de características e conclusões extraídas no âmbito de IPI e ICMS”.

Esse também o entendimento de Fátima Fernandes Rodrigues de Souza e Ives Gandra da Silva Martins, ${ }^{325}$ para os quais a compatibilização da aplicação da técnica nãocumulativa nos moldes do IPI e do ICMS àquelas contribuições demanda "grande esforço exegético”, justamente por causa da materialidade do PIS e da Cofins.

Em estudo autônomo, Fátima Fernandes Rodrigues de Souza ${ }^{326}$ assevera que, se o pressuposto material do PIS e da Cofins fosse apenas o faturamento, poder-se-ia conceber sua não-cumulatividade nos moldes da do IPI e do ICMS, muito embora a própria autora ressalve que faturamento e operações são materialidades distintas.

Para Ricardo Lobo Torres, ${ }^{327}$ o mecanismo da não-cumulatividade do IPI e do ICMS não pode ser extrapolado para o que chama de "exóticas contribuições sociais brasileiras, que incidem sobre receitas estranhas ao movimento de vendas, sob pena de introduzir sérias distorções técnicas e jurídicas na sua aplicação”.

Já Misabel Derzi e Sacha Calmon Navarro Coelho ${ }^{328}$ vislumbram certa similitude entre as sistemáticas da não-cumulatividade das aludidas contribuições e a do IPI no que pertine ao aproveitamento dos créditos relativos a insumos isentos, com alíquota zero e não tributados. Lecionam que, nesse particular, o que se disse sobre a não-cumulatividade do IPI aplica-se, com temperamentos, ao PIS e à Cofins, cuja legislação “tomou como padrão a não-

\footnotetext{
324 Não-cumulatividade no PIS e na Cofins cit., p. 102.

325 A não-cumulatividade das contribuições: PIS/Pasep e Cofins. In: PAULSEN, Leandro (Coord.) et al. Nãocumulatividade do PIS/Pasep e da Cofins. São Paulo: IOB Thompson; Porto Alegre: Instituto de Estudos Tributários, 2004.. p. 24.

326 Apud SILVA, Ives Gandra Martins da; FERNANDES, Edison Carlos. Não-cumulatividade do PIS e da Cofins. São Paulo: Quartier Latin, 2007. p. 77.

327 A não-cumulatividade no PIS/Cofins cit., p. 53-74, especialmente p. 56.

328 PIS/Cofins: direito de crédito nas entradas e saídas isentas ou com alíquota zero. Revista Dialética de Direito Tributário, n. 115, p. 143-154, especialmente p. 153-154, São Paulo: Dialética.
} 
cumulatividade do IPI, que é imposto federal” e, por isso, não “ofereceu restrições ao princípio em sua plenitude doutrinária e constitucional, pois não remeteu ao ICMS, locus onde existem restrições”.

Posição isolada ${ }^{329}$ é a de Ricardo Mariz de Oliveira, ${ }^{330}$ para quem o § 12 do art. 195 da CF/88 não trata daquilo que, em suas palavras, seria a "não-cumulatividade no sentido jurídico”. O autor quer dizer que o dispositivo não se refere ao abatimento da contribuição incidente em etapa anterior para fins de cálculo da contribuição a pagar - essa, a seu ver, a não-cumulatividade no sentido jurídico -, mas, sim, à permissão para que as contribuições sobre a receita "sejam não cumulativas com a contribuição sobre a importação de bens e serviços”. ${ }^{331}$ Diz que, como o $\S 12$ do art. 195 da CF/88 remete tanto às contribuições dos incisos I, $b$, e IV do caput (incidentes, respectivamente, sobre a receita, o faturamento e o lucro; e sobre a importação), tivesse a referida norma querido se referir à "não-cumulatividade no sentido jurídico", ter-se-ia que admitir que autorizara o legislador infraconstitucional a estabelecer a não-cumulatividade também para o PIS e a Cofins importação - o que seria um absurdo lógico, pois a incidência sobre a importação é monofásica por si só: não há PIS e Cofins importação devidos em etapas anteriores que possam ser abatidos do PIS e da Cofins devidos na importação. ${ }^{332}$ Afirma, ainda, que qualquer incidência sobre a receita é, por sua própria natureza, plurifásica e cumulativa, pois seu substrato é o recebimento de cada receita, isolada e de per si. ${ }^{333}$ Por isso conclui que a não-cumulatividade das contribuições em causa nada tem a ver com a do IPI e do ICMS, impostos que, segundo o mencionado tributarista, são mandatoriamente não-cumulativos "porque visam atos com determinadas coisas postas em circulação, o que não ocorre com outros tributos”. ${ }^{334}$

\footnotetext{
329 Em nossas pesquisas, não encontramos outros autores que partilhem desse entendimento.

330 Aspectos relacionados à “não-cumulatividade”... cit., p. 36.

331 Idem, ibidem, p. 34.

332 Idem, p. 35-36.

333 Idem, p. 27.

334 Aspectos relacionados à “não-cumulatividade”... cit., p. 23-28. Discordamos de Ricardo Mariz quando diz que IPI e ICMS teriam que ser, mandatoriamente, por sua natureza, não-cumulativos. Entendemos que poderiam ser cobrados por sistemática plurifásica cumulativa ou mesmo monofásica. Sua nãocumulatividade é mandatória porque assim estipulou o legislador constituinte de 1988.
} 
De tudo o quanto foi dito julgamos adequado concluir que não há um significado único de não-cumulatividade no texto constitucional. Ou seja, a não-cumulatividade do PIS e da Cofins é diferente da não-cumulatividade do IPI e do ICMS.

Apesar de onerarem a mesma fonte tributável, esses tributos recaem sobre diferentes parcelas da realidade. IPI e ICMS lidam com coisas materiais; PIS e Cofins lidam com receitas, inclusive as financeiras ${ }^{335}$.

No IPI e no ICMS, a não-cumulatividade tem todos os objetivos que conduziram à sua criação nos tributos sobre vendas/consumo: afastar os inconvenientes econômicos da tributação plurifásica cumulativa e repassar adiante o encargo jurídico do tributo.

No PIS e na Cofins, ausente a translação jurídica do encargo, pode-se entender que a não-cumulatividade visa a evitar a sobreposição de cargas tributárias que distorce a formação dos preços, desestimula investimentos e exportações e ocasiona desvios na concorrência, ou seja, contribui para a neutralidade tributária. Essa a ratio constante das Exposições de Motivos das Medidas Provisórias 66/2002 e 135/2003.

Além disso, para aqueles impostos, a não-cumulatividade é mandatória porque decorre da Constituição; para as contribuições, depende do querer do legislador. E quem pode o mais - no caso, estabelecer os setores para os quais haverá a não-cumulatividade do PIS e da Cofins - pode também o menos - v. g. estabelecer exceções ao creditamento.

\subsubsection{Significados possíveis da não-cumulatividade do PIS e da Cofins}

Quando analisamos a tributação sobre vendas, vimos que a carga dos tributos incidentes sobre a circulação de riquezas e o nível da arrecadação serão maiores se o sistema for plurifásico cumulativo. Vimos também que o ônus tributário e o nível de arrecadação serão menores se o sistema for não-cumulativo, seja adotando-se a incidência monofásica, ${ }^{336}$ seja adotando-se incidência plurifásica, mas que os efeitos sobre a economia e a facilidade de arrecadação compensam essa perda de arrecadação.

Constatamos, ainda, que os efeitos econômicos da adoção da técnica não-cumulativa monofásica e ou da técnica não-cumulativa plurifásica (sobre o valor agregado) são distintos,

\footnotetext{
335 Todavia, o Dec. 5.442/2005, reduziu a zero a alíquota do PIS e da Cofins incidentes sobre as receitas financeiras..

336 E nessa técnica, os efeitos variarão conforme o estágio em que se estabelecer a tributação (produção, atacado ou varejo).
} 
mas que, em geral, nem o peso da carga tributária nem o nível de arrecadação sofrerão alterações muito relevantes com a opção por uma ou por outra. Donde concluirmos que, mantida a alíquota, a sistemática plurifásica não-cumulativa não implica, em relação à sistemática unifásica, nem majoração nem redução da carga tributária, mas apenas sua distribuição de forma mais adequada ao longo da cadeia de circulação das riquezas.

Logo, a passagem do PIS e da Cofins da sistemática plurifásica cumulativa para a plurifásica não-cumulativa poderia ter sido feita com manutenção do nível de arrecadação, bastando um aumento de alíquotas.

Portanto, se assumirmos como verdadeira a premissa de que a instituição da nãocumulatividade não alterou a carga tributária - isto é, partindo-se do pressuposto de que a alíquota anterior cumulativa (3,65\%) equivale à atual alíquota não-cumulativa $\left(9,25 \%{ }^{337}\right)$ - a não-cumulatividade das contribuições PIS e Cofins representa técnica de arrecadação daquelas contribuições incidentes sobre a circulação de riquezas. Suas finalidades, como técnica de arrecadação, são: contribuir para a neutralidade ou funcionar como norma tributária indutora, destinada a promover fins extrafiscais, como o equilíbrio da concorrência, nos termos do art. 146-A da CF/88.

Mas, se apenas o aumento de alíquotas fosse suficiente para manter o nível de arrecadação, não constaria das Exposições de Motivos das Medidas Provisórias 66/2002 e 135/2003 (convoladas nas Leis 10.637/2002 e 10.833/2003) que a nova sistemática implicava a "redistribuição da carga tributária entre os setores". ${ }^{338}$ Portanto, assumindo como certo que houve aumento da carga tributária para alguns setores, a não-cumulatividade do PIS e da Cofins não pode ser tida como técnica de arrecadação que contribui para a neutralidade ou induz o equilíbrio da concorrência; assemelha-se mais a uma sistemática de desonerações ${ }^{339}$ para determinados setores, que implica a oneração de outros.

337 A alíquota do PIS passou de 0,65\% para 1,65\% e a da Cofins de 3\% para 7,6\%. A soma das alíquotas que era de $3,65 \%$ passou a ser de $9,25 \%$.

338 Cf. item 4 das Exposições de Motivos de ambas as medidas provisórias.

339 De acordo com Ives Gandra Martins Silva e Fátima Fernandes Rodrigues de Souza (Não-cumulatividade do PIS e da Cofins cit., p. 24), a não-cumulatividade do PIS e da Cofins tem o caráter "de mera redução da base de cálculo, tendo como critério referencial o quantum incidente anteriormente sobre faturamento e receita tributados”. No mesmo sentido, Pedro Guilherme Accorsi Lunardelli, as Leis 10.637/2002 e 10.833/2003 (Não-cumulatividade da contribuição ao PIS. Revista Dialética de Direito Tributário, n. 95, p. 116, apud 
Em artigo sobre o tema, Douglas Yamashita ${ }^{340}$, firme em que a não-cumulatividade possibilita "aferição mais precisa da capacidade contributiva subjetiva”, averba que

não resta dúvida de que a sistemática não-cumulativa autorizada pelo § 12 do art. 195 da CF/88 tem finalidade fiscal, sendo sua previsão legal ou consitucional legítima concretização do princípio da capacidade contributiva.

Não há, portanto, apenas um significado de não-cumulatividade na Constituição. Reforça essa conclusão o fato de o art. 154, I da CF/88, ao regular a competência residual da União, estabelecer que os novos impostos assim criados devam adotar técnica impositiva nãocumulativa. $^{341}$ Se a não-cumulatividade implicasse necessariamente a transferência do encargo tributário para o consumidor (tal como ocorre no IPI e no ICMS), a competência residual da União estaria limitada à criação de tributos sobre a riqueza consumida e lhe seria vedado instituir outras exações sobre riquezas acumulada e produzida - o que demonstra a impropriedade do raciocínio, pois limitação desse quilate deveria vir explícita, e não implícita. Além disso, como anotamos em itens precedentes, a tributação sobre o valor agregado é compatível com tributos incidentes sobre a renda. ${ }^{342}$

\subsection{Princípios relacionados à não-cumulatividade do PIS e da Cofins}

Como visto no Capítulo 3, as normas que estabelecem a não-cumulatividade podem assumir feição de princípio ou de regra.

TOMÉ, Fabiana del Padre. PIS - Cofins, p. 548). Refinando o raciocínio, Ives Gandra da Silva Martins e Edison Carlos Fernandes (Não-cumulatividade do PIS e da Cofins cit., p. 77), firmes nas exposições de motivos das Medidas Provisórias 66/02 e 135/03, em cujos termos o principal objetivo da nãocumulatividade das contribuições sob estudo é estimular a eficiência econômica e o crescimento da economia e, tendo em vista que "a concessão do crédito fiscal não impõe nenhuma vinculação com o quantum recolhido nas etapas anteriores” (tanto que pagamentos feitos a empresas optantes pelo Simples ensejam creditamento sem restrições), entendem que as Leis 10.637/2002 e 10.833/2003 teriam criado "uma forma de não-cumulatividade correspondente a autêntica subvenção pública [...]”, que implica transferência de recursos públicos para empresas privadas de determinados setores, com a finalidade específica de que sejam aplicados em investimentos.

${ }^{340}$ Discriminação de Situações Sujeitas às Sistemáticas Cumulativa ou Não-Cumulativa do PIS e da Cofins: Limitações Constitucionais. In: COELHO, Sacha Calmon Navarro (Coord.). Contribuições para a Seguridade Social. São Paulo: Quartier Latin, 2007, p. 274 (destaques no original).

341 Cf. Sacha Calmon Navarro Coelho, o art. 154, II determina à União a observância da "técnica impositiva cumulativa” quando da instituição de impostos residuais (Comentários à Constituição de 1988 - Sistema Tributário cit., p. 185).

342 Tanto que o método aditivo de cálculo do valor agregado se assemelha à apuração da base de cálculo do IRPJ. 
Analisada sob a perspectiva de regra, a não-cumulatividade do PIS e da Cofins determina o abatimento dos créditos relativos a determinados insumos, constituindo forma de arrecadação que visa a facilitar a administração das referidas contribuições.

Sua perspectiva de princípio (comportamento mediato, visando à realização do estado ideal das coisas; dimensão finalística imediata) dependerá do significado adotado: (i) pode entender-se que a não-cumulatividade do PIS e da Cofins visa a distribuir a carga tributária no processo de circulação de riquezas de forma mais adequada e a corrigir desequilíbrios na concorrência (princípio da neutralidade) ou que (ii) é meio para desonerar a tributação de determinados setores (princípios da isonomia e da capacidade contributiva).

Valem aqui, para o PIS e a Cofins, as mesmas ponderações feitas a respeito da vinculação da não-cumulatividade do IPI e do ICMS aos princípios da neutralidade e da capacidade contributiva anteriormente, com a diferença de que, como a não-cumulatividade do PIS e da Cofins não é instrumento que viabiliza o repasse dos respectivos encargos jurídicos adiante, a capacidade contributiva que se deve ter em mira é a do agente econômico (sujeito passivo) e não a do consumidor. Daí a não-cumulatividade das referidas contribuições não estar associada à seletividade, princípio por meio do qual a tributação deve ser menos rigorosa para produtos e serviços considerados essenciais ao consumidor.

No que tange ao comércio exterior (neutralidade concorrencial entre no âmbito internacional), a não-cumulatividade do PIS e da Cofins, ao lado da instituição do PISimportação e da Cofins-importação, pretenderam atender a reclamo antigo do empresariado, e tiveram por finalidade colocar o produto nacional em condições mais aproximadas do produto estrangeiro, tanto na exportação (porque a pretendida não-cumulatividade facilitaria a recuperação das contribuições incidentes nas etapas anteriores) como na importação, eis que os produtos estrangeiros também pagarão as referidas contribuições (PIS e Cofins na importação).

\subsection{Não-cumulatividade do PIS e da Cofins teria status constitucional?}

Se existe consenso sobre serem distintas as não-cumulatividades do PIS e da Cofins e do IPI e do ICMS, o mesmo não ocorre quando a questão é saber se, para as contribuições, o mecanismo tem perfil constitucional ou é assunto que pode ser inteiramente regulado por lei ordinária. 
Dos autores antes mencionados, Ricardo Mariz de Oliveira, Marco Aurélio Greco e Ives Gandra Martins Silva entendem que a não-cumulatividade do PIS e da Cofins não decorre do texto constitucional e poderia ter sido veiculada apenas por lei ordinária - como efetivamente ocorreu, já que as Leis 10.637/2002 e 10.833/2003 precederam a EC 42/2003. ${ }^{343}$

Por outro lado, Natanael Martins, ${ }^{344}$ Sacha Calmon, Misabel Derzi ${ }^{345}$ e Heleno Taveira Torres ${ }^{346}$ entendem que a referida não-cumulatividade está radicada na CF/88 e que ao legislador ordinário só caberia escolher as situações nas quais seria aplicável, sempre com intuito do discrímen indicado pelo contribuinte - o setor de atividade econômica.

Ambas as correntes têm uma parcela de razão.

Como escrevemos anteriormente, a não-cumulatividade é uma das possíveis técnicas de arrecadação dos tributos incidentes sobre a circulação de riquezas. Terá característica de princípio - e, nesse sentido, afigura-se adequada sua radicação no texto constitucional quando, além de desonerar o preço final da mercadoria, tiver o objetivo de promover o repasse do encargo jurídico do tributo adiante, adequando a tributação à capacidade contributiva do consumidor e ensejando a neutralidade dos tributos sobre a circulação de

343 Para Ricardo Mariz, a não-cumulatividade das contribuições não é ditame constitucional, ficando à discricionariedade do legislador ordinário admiti-la ou não (O conceito de receita como hipótese das contribuições... cit., p. 28). Ricardo Lobo Torres, ao menos nas obras consultadas, não aborda o tema. Segundo Marco Aurélio Greco, “a não-cumulatividade criada pelas mencionadas Leis (10.637/2002 e 10.833/2003) não foi desdobramento de determinação constitucional” (Não-Cumulatividade no PIS e na Cofins cit, p. 102). Ives Gandra Martins Silva registra que a não-cumulatividade daquelas contribuições não está desenhada na Constituição como a do IPI e do ICMS (Não-cumulatividade no PIS e na Cofins cit., p. 76).

344 Confiram-se as palavras do autor: “o conceito da não cumulatividade, que derivava, exclusivamente, da vontade do legislador ordinário, tem assento no texto constitucional” (O Conceito de Insumos na Sistemática Não-Cumulativa do PIS e da Cofins In: PEIXOTO. Marcelo Magalhães; FISCHER, Octávio Campos (coord.). PIS-Cofins: questões atuais e polêmicas. São Paulo: Quartier Latin, 2005, p. 201).

345 Segundo os autores, “o princípio da não-cumulatividade do PIS/Cofins, hoje de radicação constitucional, salvo melhor juízo, pois ao tornar não-cumulativas essas contribuições a poder de reforma, não remeteu à legislação infração constitucional [sic - seria infraconstitucional?] o poder de definir a tipologia dessa nãocumulatividade” (PIS/Cofins: direito de crédito nas entradas e saídas isentas ou com alíquota zero cit., p. 153.)

346 Para esse tributarista, a não-cumulatividade do PIS e da Cofins tem assento na Constituição e, "como medida inerente ao direito de tributação segundo a capacidade contributiva [...] assoma-se aos direitos individuais protegidos pelo art. 60, p. 4. ${ }^{\circ}, d$, da CF [...]” (Monofasia e não-cumulatividade ... cit., p. 33), cabendo ao legislador ordinário apenas duas opções, (i) garantir a não-cumulatividade de acordo com o setor de atividade econômica, reservando a cumulatividade para atividades onde não fosse possível o desconto de créditos; (ii) ou estabelecer alíquotas diferentes para fomentar determinadas atividades, mas nunca restringir os descontos aos créditos (idem, ibidem, p. 31-33). 
riquezas. Não é o que ocorre com o PIS e Cofins, pelas razões já expostas. Portanto, sua nãocumulatividade não precisaria ter sido colocada na Constituição. Só o foi, devido ao receio de que os setores não contemplados com a nova sistemática atacassem o regime por entendê-lo anti-isonômico.

Todavia, uma vez vinculada ao texto constitucional como sistemática a ser implantada para determinados setores de atividade econômica, impõe-se ao legislador ordinário seguir esse critério de discrímen, seguindo correlação lógica entre o objetivo/valor que persegue: facilidade de arrecadação e administração do tributo e equilíbrio da concorrência ou desoneração de determinados setores.

\subsection{Fatores de discrímen: os setores de atividade econômica}

O § 12 do art. 195 da CF/88 dispõe que a lei definirá os setores de atividade econômica para os quais as contribuições incidentes sobre a receita, o faturamento, o lucro e as importações serão não-cumulativas.

Doutrina especializada do direito civil $^{347}$ ensina que atividade econômica é a atividade criadora de riquezas; a atividade economicamente organizada para a produção ou a circulação de bens ou serviços; a série de atos com os quais o empresário organiza o trabalho alheio e os capitais próprios e alheios, com o fim de produção e distribuição de bens se serviços para o mercado de consumo; a atividade dirigida ao mercado (em contraposição aos atos jurídicos, gênero ao qual pertence a espécie negócios jurídicos que são dirigidos a um destinatário específico); a "atividade que se manifesta economicamente na empresa e se exprime juridicamente na titularidade do empresário e no modo ou nas condições de seu exercício"; 348 em suma, a atividade é mais que a soma dos atos que a compõem, como o filme é mais que as fotos: colocadas em movimento, transubstanciam-se.

Na CF/88, a palavra setor é utilizada em diversos sentidos: (i) ora para referir-se à necessidade de o Governo providenciar meios para o desenvolvimento econômico nacional

347 CORRÊA, Rodrigo Arantes Barcellos. Os contratos atípicos interempresariais e os contratos de Shopping Center. 2008. Dissertação (Mestrado) - USP, São Paulo, p. 81-82.

348 MARCONDES, Sylvio. Da atividade empresarial. Problemas de direito mercantil. São Paulo: Max Limonad, 1970. Apud CORRÊA, Rodrigo Arantes Barcellos. Os contratos atípicos interempresariais... cit., p. 82. 
uniforme dos diversos setores sociais; ${ }^{349}$ (ii) ora para designar a oposição entre setor público e privado; ${ }^{350}$ e (iii) outras tantas vezes para designar as diferentes seções do setor público e do setor privado, ${ }^{351}$ com significado tal qual encontrado nos léxicos, como sinônimo de porção, parte, área, subdivisão, zona, divisão, esfera, ramo. ${ }^{352}$ É o que ocorre quando o constituinte

349 Como se verifica no art. 23, que fala da competência comum da União, Estados e Municípios para "X combater as causas da pobreza e os fatores de marginalização, promovendo a integração social dos setores desfavorecidos"; no art. 48, que arrola, dentre as atribuições do Congresso, a de estabelecer "IV - planos e programas nacionais, regionais e setoriais de desenvolvimento; no art. 58, quando dita, dentre as atividades das Comissões do Congresso, a de "VI - apreciar programas de obras, planos nacionais, regionais e setoriais de desenvolvimento e sobre eles emitir parecer”; no art. 165, que ao abordar as matérias atinentes às leis de iniciativa do Poder Executivo, diz, no $§ 4 .^{\circ}$, que "os planos e programas nacionais, regionais e setoriais previstos nesta Constituição serão elaborados em consonância com o plano plurianual e apreciados pelo Congresso Nacional”; e no art. 166, ao indicar a competência das comissões de senadores e deputados para, ao analisar o orçamento geral "II - examinar e emitir parecer sobre os planos e programas nacionais, regionais e setoriais previstos nesta Constituição e exercer o acompanhamento e a fiscalização orçamentária, sem prejuízo da atuação das demais comissões do Congresso Nacional e de suas Casas, criadas de acordo com o art. 58".

350 Como se verifica dos seguintes dispositivos: art. 173, que diz que tipo de atividade econômica o Estado poderá explorar diretamente: "§ $2 .^{\circ}$ as empresas públicas e as sociedades de economia mista não poderão gozar de privilégios fiscais não extensivos às do setor privado"; art. 174, segundo o qual o Estado "como agente normativo e regulador da atividade econômica" que "exercerá, na forma da lei, as funções de fiscalização, incentivo e planejamento, sendo este determinante para o setor público e indicativo para o setor privado"; art. 201, que fala da organização da previdência social: "§ 10. Lei disciplinará a cobertura do risco de acidente do trabalho, a ser atendida concorrentemente pelo regime geral de previdência social e pelo setor privado"; e art. 8. ${ }^{\circ}$ do ADCT, ao regular a anistia aos exilados políticos, garantindo-lhes o retorno aos cargos e funções que tinham no setor público e assegurando, no $\S 2 .^{\circ}$ os mesmos benefícios "aos trabalhadores do setor privado, dirigentes e representantes sindicais que, por motivos exclusivamente políticos, tenham sido punidos, demitidos ou compelidos ao afastamento das atividades remuneradas que exerciam, bem como aos que foram impedidos de exercer atividades profissionais em virtude de pressões ostensivas ou expedientes oficiais sigilosos".

351 É o que faz ao tratar das diferenças entre os setores da administração pública, indicando, no art. 37, que: "XVIII - a administração fazendária e seus servidores fiscais terão, dentro de suas áreas de competência e jurisdição, precedência sobre os demais setores administrativos, na forma da lei”; ao dizer, no art. 187, que a política agrícola será planejada e executada a política agrícola "com a participação efetiva do setor de produção, envolvendo produtores e trabalhadores rurais, bem como dos setores de comercialização, de armazenamento e de transportes [...]"; no art. 239, quando estabelece, no $\S 4 .^{\circ}$, que "o financiamento do seguro-desemprego receberá uma contribuição adicional da empresa cujo índice de rotatividade da força de trabalho superar o índice médio da rotatividade do setor, na forma estabelecida por lei”; no art. 55 do ADCT, que destinou ao setor saúde pelo menos $30 \%$ do orçamento da seguridade social, excluído o segurodesemprego, até fosse aprovada a lei de diretrizes orçamentárias; no art. 41 do ADCT, quando diz que "os Poderes Executivos da União, dos Estados, do Distrito Federal e dos Municípios reavaliarão todos os incentivos fiscais de natureza setorial ora em vigor, propondo aos Poderes Legislativos respectivos as medidas cabíveis”; e no art. 158, segundo o qual a União deve entregar aos Municípios, determinados percentuais das receitas arrecadadas, sendo "c) três por cento, para aplicação em programas de financiamento ao setor produtivo das Regiões Norte, Nordeste e Centro-Oeste, através de suas instituições financeiras de caráter regional, de acordo com os planos regionais de desenvolvimento, ficando assegurada ao semi-árido do Nordeste a metade dos recursos destinados à Região, na forma que a lei estabelecer".

352 Novo dicionário Aurélio da língua portuguesa. 2. ed. Nova Fronteira: "setor. [Var. de sector <lat. Sectore.] S.m. 1. Subdivisão de uma região, zona, distrito, seção, seção, etc.: Trabalha no setor norte da cidade. 2. Seção (8): setor médico. 3. Esfera ou ramo de atividade; campo de ação; âmbito: setor financeiro. 4. Mil. Zona de ação no combate defensivo, ou circunscrição territorial confiada a uma unidade militar. 5. Mil. Parte de um local fortificado posta sob o comando de um oficial [...]”. 
menciona os setores de comércio, de transportes, de armazenagem (art. 187 da CF/88) e de saúde (art. 55 do ADCT), deixando claro que ao falar em setores de atividade econômica não se referiu à divisão clássica da Economia, entre os setores primário (agricultura e extrativismo), secundário (produção) e terciário (serviços), mas às subdivisões desses grupos, ou seja, àquilo que os civilistas dizem ser a atividade econômica propriamente dita.

No § 12 do art. 195 da CF/88, a expressão setores de atividade econômica remete às fontes de riqueza aptas a custear as despesas da previdência social. Alinha-se, portanto com o significado que designa as diferentes seções do setor privado, ou seja, representa os distintos segmentos de atividades economicamente organizadas para a produção e circulação de riquezas.

Daí entendermos que os setores de atividade econômica a que se refere o § 12 do art. 195 da CF/88 são as diversas parcelas da atividade empresarial.

Disso decorrem duas conclusões: (i) são inadequadas as discriminações em função outros fatores, que não os setores de atividade econômica, tais como: a apuração do lucro tributável pelo IRPJ, presumido ou arbitrado (art. 8. ${ }^{\circ}$, inc. II, da Lei 10.637/2002 e 10, inc. II, da 10.833/2003), a data de celebração dos contratos (art. 10, inc. XI, da Lei 10.833/2003 para a Cofins e art. 15 da Lei 10.833/2003, na redação dada pelo art. 15 da Lei 10.865/2004 para o PIS) $)^{353}$ e a forma de organização societária (art. 10, inc. VI, da Lei 10.833/2003, sociedades cooperativas) e (ii) não haveria, a princípio, impropriedade no fato de as Leis 10.637/2002 e 10.833/2003 terem indicado as atividades excepcionadas da sistemática não-cumulativa, ${ }^{354}$ como é o caso, exemplificativamente, do inc. V do art. 10 da Lei 10.833/2003 (órgãos públicos, autarquias, fundações públicas e fundações cuja criação tenha sido autorizada por lei), do inc. VII, $a$, do art. 10 da mesma lei (de venda de álcool para fins carburantes), do inc. VIII do mesmo dispositivo legal (receitas decorrentes de serviços de telecomunicações), e do

353 Igor Santiago e Valter Lobato, escrevendo sobre a não-cumulatividade do PIS e da Cofins para as receitas derivadas de contratos com prazo de duração superior a um ano, com preço determinado, celebrados até 31.03.2003, afirmam que, para ser compatível com a Constituição, a regra deve ser reputada opcional (Análise dos arts. 10, XI, e 15, V, da Lei 10.833/2003 cit., p. 582-583).

354 Em sentido contrário, Octávio Campos Fischer entende a não-cumulatividade deveria ser realizada entre os setores de atividades econômicas e não entre atividades econômicas, pois dentro de um mesmo setor podem ser encontrados vários tipos de atividades econômicas (PIS-Cofins, não cumulatividade e a Emenda Constitucional n. 42/03. PIS-Cofins Questões ..., p. 196). 
inc. XIII, $a$ e $b$, do referido dispositivo (receitas de serviços prestados por hospitais, prontosocorros, clínicas médicas, odontológicas, de diálise, de banco de sangue, etc.).

Mas é cediço que qualquer tratamento diferenciado deve respeitar os elementos há muito indicados por Celso Antônio Bandeira de Mello $^{355}$ ao discorrer sobre o princípio da igualdade: a relação entre o fator de distinção eleito e o tratamento preconizado (consequência) deve ser lógica, os critérios de discrímen devem ser gerais, intrínsecos à pessoa/coisa/situação e alinhados a interesses e valores constitucionalmente eleitos.

Por isso, apesar de não existir, a princípio, impropriedade na designação de que o PIS e a Cofins sejam não-cumulativos para determinadas atividades econômicas, a seleção dessas atividades só será válida se for lógica, intrínseca à atividade e perseguir determinados valores prestigiados pela Constituição. Caso contrário, será casuística e fruto da maior ou menor pressão exercida por determinados setores sobre o Poder Legislativo.

Nesse sentido, as lições de Humberto Ávila ${ }^{356}$ a respeito do § 9. ${ }^{\circ}$ do art. 195 da CF/88 aplicam-se também ao § 12 do art. 195 da CF/88:

o legislador não está livre para simplesmente estabelecer alíquotas ou bases de cálculo diferentes em razão da atividade econômica, da utilização intensiva da mão-de-obra, do porte da empresa ou da condição estrutural do mercado de trabalho. O legislador, em vez disso, deverá us[á-los] [...] para atingir determinadas finalidades constitucionalmente previstas. [...] Se a diferenciação baseada na atividade econômica, por exemplo, produzir efeitos que alterem a livre escolha da profissão ou que causem um impacto desfavorável anormal para determinado tipo de atividade, a diferenciação estará vedada por atingir o núcleo do princípio da liberdade de profissão e de exercício de atividade econômica.

Saber quais setores de atividade econômica devem se sujeitar à não-cumulatividade do PIS e da Cofins (cf. § 12 do art. 195 da CF/88) dependerá do significado atribuído à não-

355 Cf. referência bibliográfica da obra “O conteúdo jurídico do princípio da igualdade”. No mesmo sentido, Roberto Sampaio Dória esclarece que "devem, portanto, ser considerados, na análise sobre se a lei tributária obedece ao requisito da igualdade, os seguintes fatores: (a) razoabilidade da discriminação, baseada em diferenças reais entre as pessoas ou objetos taxados; (b) existência de objetivo que justifique a discriminação; (c) nexo lógico entre o objetivo perseguido e a discriminação que permitirá alcançá-lo." Princípios constitucionais tributários e a cláusula due process of law. Tese (Concurso à livre docência da Cadeira de Direito Financeiro da Faculdade de Direito da USP). São Paulo, 1964, p. 195 in fine e 196.

356 Sistema constitucional tributário. 3. ed. rev. e atual. São Paulo: Saraiva, 2006. p. 277. 
cumulatividade daquelas contribuições ${ }^{357}$ : (i) se entendida como uma sistemática de arrecadação que contribui para a neutralidade, a escolha dos contribuintes aos quais se aplica a referida sistemática (i.a) deve pautar-se em critérios de conveniência e facilidade de arrecadação e fiscalização, aplicando-se aos setores onde houver maior sonegação e perda de receitas da União ou (i.b) deve ser feita a partir da análise dos setores mais propensos à concentração vertical e a outras formas de organização prejudicial à concorrência; (ii) se encarada como uma sistemática de desonerações, o tratamento diferenciado deverá observar a isonomia, visando distribuir a carga tributária para setores com maior capacidade contributiva; nesse caso, a escolha dos setores não será coisa singela e deverá observar parâmetros de justiça fiscal e capacidade contributiva ${ }^{358}$.

Heleno Taveira Tôrres, interpretando conjuntamente os $\S \S 9 .^{\circ}$ e 12 do art. 195 da $\mathrm{CF} / 88$, preconiza que, ao selecionar os setores para os quais aquelas contribuições seriam não-cumulativas, o legislador ordinário deveria pautar-se nos critérios de utilização intensiva de mão-de-obra ou de atividade econômica. ${ }^{359}$

Segundo esse autor, ${ }^{360}$

em uma interpretação rigorosamente conforme a Constituição, a seleção dos setores deveria acompanhar os critérios constitucionais da atividade econômica ou da utilização intensiva de mão-de-obra (art. 195, § 9. ${ }^{\circ}, \mathrm{CF}$ ), que não poderiam ser afastados dessa hipótese, ao servir, com legitimidade única, à separação dos regimes aplicáveis às pessoas jurídicas.

357 Por entender que o art. 146-A da CF/88 explicita o princípio da neutralidade tributária, José Luis R. Brazuna e forte na premissa de que a não-cumulatividade visa a tornar a tributação neutra, conclui que a escolha dos setores para os quais deve ser aplicada a não-cumulatividade do PIS e da Cofins “deverá se pautar, dentre outros elementos considerados relevantes, pelo princípio da neutralidade tributária explicitado no art. 146-A, buscando-se eliminar, diante da realidade de cada mercado específico, eventuais efeitos danosos provocados pela cobrança cumulativa das contribuições em questão” (Neutralidade tributária e uso da tributação para prevenir desequilíbrios da concorrência. cit., p. 171.).

358 Tratando da Cofins, Douglas Yamashita diz que “... sob este prisma da capacidade contributiva, os créditos outorgados na sistemática não-cumulativa da Cofins, apesar de sua alíquota ser de 7,6\%, não nos permitem afirmar abstrata e genericamente que um contribuinte sujeito a esta sistemática esteja sempre sujeito a um tratamento tributário mais oneroso que outro contribuinte sujeito à sistemática cumulativa, que não dá direito a créditos, embora sua alíquota seja de 3\%. Tudo depende de cada caso concreto. O mesmo vale para a contribuição ao PIS. Discriminação de Situações Sujeitas às Sistemáticas ... cit., p. 279 in fine e 280.

${ }^{363}$ Monofasia e não-cumulatividade ... cit., p. 35.

360 TÔRRES, Heleno Taveira. Monofasia e não-cumulatividade ... cit., p. 34. 
Ricardo Mariz de Oliveira ${ }^{361}$ averba que, antes mesmo do acréscimo do § 12 ao art. 195 da CF/88, o § 9. ${ }^{362}$ do mesmo dispositivo já emprestava validade à instituição do PIS e da Cofins não-cumulativos ao autorizar a instituição de alíquotas ou bases diferenciadas para as contribuições incidentes sobre a receita, o faturamento ou o lucro. É que, para o mencionado autor, a concessão de deduções para fins de apuração das contribuições a pagar (os créditos do PIS e da Cofins não-cumulativos) equivale à instituição de bases de cálculo distintas. E, como já vimos, o referido autor entende que a não-cumulatividade do $\S 12$ ao art. 195 da CF/88 não é jurídica, mas, sim, econômica, equivalente a uma desoneração do encargo tributário.

Latente, no entendimento dos mencionados tributaristas, o reconhecimento de que a não-cumulatividade implicou a diferenciação da carga tributária entre os setores de atividade econômica.

\subsection{Os créditos e os insumos}

Não há consenso na doutrina sobre o método de cálculo que o legislador teria adotado para o PIS e para a Cofins, se o aditivo ou o subtrativo, nem sobre se teria incorporado a variante a base sobre base (subtrativo direto) ou tributo contra tributo (subtrativo indireto).

A exposição de motivos da MP 66/2002 diz tratar-se de método subtrativo direto. Pautados nisso, Edison Carlos Fernandes e Ives Gandra Martins da Silva afirmam o mesmo. ${ }^{363}$ Ricardo Lobo Torres entende estarmos diante do método base sobre base. ${ }^{364}$

Retomemos, sucintamente, as diferenças entre os referidos métodos de cálculo do imposto sobre o valor agregado, relembrando que todos partem da base financeira, em oposição à base real, pois não é feita a correlação real, minuciosa, dos estoques utilizados na

\footnotetext{
361 Aspectos relacionados à “não-cumulatividade”... cit., p. 37.

362 “§ 9. ${ }^{\circ}$ As contribuições sociais previstas no inciso I do caput deste artigo poderão ter alíquotas ou bases de cálculo diferenciadas, em razão da atividade econômica, da utilização intensiva de mão-de-obra, do porte da empresa ou da condição estrutural do mercado de trabalho.”

363 Não-cumulatividade do PIS e da Cofins cit., p. 79.

364 TORRES, Ricardo Lobo. A não-cumulatividade no PIS/Cofins cit., p. 62.
} 
confecção de cada produto ou prestação de serviços; computa-se o total das aquisições e de produtos e serviços vendidos num dado período.

Enquanto o método aditivo leva em consideração os valores efetivamente agregados ao output empresarial (incluindo juros, salários, depreciações, lucro líquido, etc.), aplicandose a alíquota sobre a referida soma, o método subtrativo considera o total das mercadorias saídas menos o total das mercadorias entradas num mesmo período e comporta duas variantes.

Na primeira variante do método subtrativo, é realizado o cotejo entre as saídas de produtos finais e as entradas de insumos, aplicando-se a alíquota do tributo sobre a diferença e por isso é chamado base sobre base. Na segunda, coteja-se o tributo devido sobre as saídas com aquele incidente sobre as entradas, recolhendo-se apenas a diferença aos cofres públicos (tributo contra tributo).

As Leis 10.637/2002 e 10.833/2003 adotam, sem sobra de dúvidas, o método subtrativo, pois seus arts. $3 .^{\circ}$ estabelecem que "do valor apurado na forma do art. $2 .^{\circ}$ a pessoa jurídica poderá descontar créditos calculados em relação a [...]”, ou seja, dispõe que o PIS e a Cofins a serão apurados mediante uma operação de subtração (dedução/desconto).

Mas, a nosso ver, a sistemática estabelecida pelas referidas leis não se adéqua nem à variante base sobre base nem à variante tributo contra tributo.

Com efeito, primeiro calcula-se o tributo a pagar. Nesse sentido, quando o art. $2 .^{\text {o365 }}$ estabelece que o montante a recolher seja determinado mediante aplicação da alíquota sobre a base de cálculo, retrata uma operação normal de cálculo de qualquer tributo cuja alíquota não seja ad valorem.

Depois, calculam-se os créditos que serão deduzidos daquele montante. O fato de o $\S$ 3. ${ }^{366}$ do art. $1 .^{\circ}$ determinar algumas deduções dessa base nada tem a ver com as deduções de

\footnotetext{
365 “Art. 2. ${ }^{\circ}$ Para determinação do valor da Cofins aplicar-se-á, sobre a base de cálculo apurada conforme o disposto no art. 1. ${ }^{\circ}$, a alíquota de 7,6\% (sete inteiros e seis décimos por cento).”

366 “ “ 3. ${ }^{\circ}$ Não integram a base de cálculo a que se refere este artigo as receitas:I - isentas ou não alcançadas pela incidência da contribuição ou sujeitas à alíquota 0 (zero); II - não-operacionais, decorrentes da venda de ativo permanente; III - auferidas pela pessoa jurídica revendedora, na revenda de mercadorias em relação às quais a contribuição seja exigida da empresa vendedora, na condição de substituta tributária; IV - de venda de álcool para fins carburantes; V - referentes a: a) vendas canceladas e aos descontos incondicionais
} 
que trata a variante base sobre base do método subtrativo. Trata-se de exclusões da base de cálculo de valores que não representam mesmo receita - e, nesse sentido, não precisariam sequer ter sido excluídas.

Também não estamos diante da variante tributo sobre tributo, pois o art. $3 .^{{ }^{367}}$ não determina que a pessoa jurídica proceda ao abatimento, compensação ou desconto do tributo incidente em operações anteriores. O dispositivo elege determinados elementos em relação aos quais poderão ser apurados créditos a serem descontados do valor encontrado no art. 2. , independentemente de ter havido incidência das contribuições sobre a receita originada a partir desses elementos em etapas anteriores.

A análise dos elementos no tocante aos quais poderão ser calculados créditos revela tratar-se ou de bens do ativo ${ }^{368}$ ou de insumos necessários à produção do output final ${ }^{369}$ ou de serviços, ${ }^{370}$ ou, ainda, de custos e despesas incorridos com a atividade empresarial. ${ }^{371}$

Definir o que são insumos para fins de creditamento do PIS e da Cofins também é questão controvertida.

concedidos; b) reversões de provisões e recuperações de créditos baixados como perda que não representem ingresso de novas receitas, o resultado positivo da avaliação de investimentos pelo valor do patrimônio líquido e os lucros e dividendos derivados de investimentos avaliados pelo custo de aquisição que tenham sido computados como receita."

367 "Art. 3. ${ }^{\circ}$ Do valor apurado na forma do art. 2. ${ }^{\circ}$ a pessoa jurídica poderá descontar créditos calculados em relação a [...]:”.

368 Vf. art. 3.․ inc. VI, das Leis 10.637/2002 e 10.833/2003: “máquinas, equipamentos e outros bens incorporados ao ativo imobilizado, adquiridos ou fabricados para locação a terceiros, ou para utilização na produção de bens destinados à venda ou na prestação de serviços - máquinas, equipamentos e outros bens incorporados ao ativo imobilizado, adquiridos ou fabricados para locação a terceiros ou para utilização na produção de bens destinados à venda ou na prestação de serviços”.

369 Vf. art. 3. ${ }^{\circ}$. inc. II das Leis 10.637/2002 e 10.833/2003: “ bens e serviços, utilizados como insumo na prestação de serviços e na produção ou fabricação de bens ou produtos destinados à venda, inclusive combustíveis e lubrificantes [...]" .

${ }^{370}$ Vf. art. $3^{\circ}$. inc. IX da Lei 10.833/2003 “armazenagem de mercadoria e frete na operação de venda, nos casos dos incisos I e II, quando o ônus for suportado pelo vendedor”.

371 Vf. art. 3.․ inc. IV das Leis 10.637/2002 e10.833/2003: "IV - aluguéis de prédios, máquinas e equipamentos, pagos a pessoa jurídica, utilizados nas atividades da empresa”; e inciso $\mathrm{V}$ das referidas leis: "V - valor das contraprestações de operações de arrendamento mercantil de pessoa jurídica, exceto de optante pelo Sistema Integrado de Pagamento de Impostos e Contribuições das Microempresas e das Empresas de Pequeno Porte - Simples”. Até a Lei 10.685/2004, também davam direito a crédito as despesas financeiras decorrentes de empréstimos e financiamentos. 
De acordo com Natanael Martins, ${ }^{372}$ justamente porque as materialidades daquelas contribuições se distinguem dos pressupostos de fato do IPI e do ICMS - em suas palavras, a materialidade do PIS e da Cofins "vai além da atividade meramente mercantil, fabril ou de serviços, alcançando todo o universo de receitas auferidas pela pessoa jurídica” - o conceito de insumos creditáveis não se assemelha ao delineado nas legislações do IPI e do ICMS. Entende o referido autor que, como as contribuições alcançam a receita total das empresas, a única forma de assegurar sua integral não-cumulatividade é se "os créditos apropriáveis alcançarem todas as despesas necessárias à consecução das atividades da empresa”. ${ }^{373}$ À vista disso, advoga a tese de que os insumos, para as Leis 10.637/2002 e 10.833/2003, são todos os custos de produção, conforme definição do art. 290 do RIR. ${ }^{374}$

Posição contrária é a de Marco Aurélio Greco, ${ }^{375}$ para quem os insumos no PIS e na Cofins não são equiparáveis àqueles indicados pela legislação do IR porque receita é materialidade distinta de renda. Explica o referido autor que, para o IRPJ e a CSLL, cujos pressupostos de fato são o resultado positivo (renda/lucro), todos os custos que interferirem na sua apuração devem ser considerados. Mas nem todos os custos da atividade empresarial interferem na formação da receita, que é materialidade do PIS e da Cofins.

Por outro lado, prossegue o tributarista, também não se aplicam para o PIS e para a Cofins os conceitos hauridos da legislação do IPI, tributo cuja não-cumulatividade se opera pelo método subtrativo, variante imposto contra imposto (que, portanto, requer tenha havido incidência na operação anterior para que o insumo seja creditável) e cuja materialidade (industrialização) remete à ideia de algo fisicamente apreensível.

372 O Conceito de Insumos na Sistemática Não-Cumulativa do PIS e da Cofins cit. p. 204.

373 Idem, ibidem.

374 Dec. 3.000/99 (RIR/99), art. 290. “O custo de produção dos bens ou serviços vendidos compreenderá, obrigatoriamente (Decreto-Lei 1.598, de 1977, art. 13, § 1. ${ }^{\circ}$ ): I - o custo de aquisição de matérias-primas e quaisquer outros bens ou serviços aplicados ou consumidos na produção, observado o disposto no artigo anterior; II - o custo do pessoal aplicado na produção, inclusive de supervisão direta, manutenção e guarda das instalações de produção; III - os custos de locação, manutenção e reparo e os encargos de depreciação dos bens aplicados na produção; IV - os encargos de amortização diretamente relacionados com a produção; V - os encargos de exaustão dos recursos naturais utilizados na produção. Parágrafo único. A aquisição de bens de consumo eventual, cujo valor não exceda a cinco por cento do custo total dos produtos vendidos no período de apuração anterior, poderá ser registrada diretamente como custo (Decreto-Lei 1.598, de 1977, art. 13, § 2..$^{\circ}$.”

375 Não-cumulatividade no PIS e na Cofins cit., p. 112-122. 
Como a receita decorre de uma prestação de serviços ou da produção de bens, Marco Aurélio Greco conclui que só deve ser insumo o que for inerente àquilo que denomina de “processo formativo da receita”. Em suas palavras:

relevante é determinar quais os dispêndios ligados à prestação de serviços e à fabricação/produção que digam respeito aos respectivos fatores de produção (= deles sejam insumos). Se entre o dispêndio e os fatores capital e trabalho houver uma relação de inerência, haverá - em princípio - direito à dedução. ${ }^{376}$

Mais adiante, esclarece que o grau de inerência do dispêndio deve ser aferido sob sua perspectiva dinâmica e não estática. É dizer, não são apenas as novas aquisições que podem ser consideradas insumos para PIS e Cofins; se o dispêndio for necessário para melhoria ou manutenção em funcionamento tanto de fatores de produção como do fator trabalho, gerará direito ao crédito.

Nessa abordagem, Marco Aurélio Greco não enfrenta quais dispêndios seriam inerentes ao processo formativo (i) das receitas financeiras, igualmente tributadas pelo PIS e pela Cofins nem (ii) das receitas obtidas com atividades comerciais. Mas, seguindo seu raciocínio, seria correto afirmar que juros e taxas bancárias ensejariam créditos compensáveis tanto na hipótese de financiamento estar diretamente ligado à prestação do serviço ou à produção/industrialização do produto (despesa diretamente inerente à formação da receita), como quando se tratar de financiamento para capital de giro, necessário à manutenção da empresa (dispêndio necessário à continuidade ou melhoria do capital, como fator de produção). ${ }^{377}$ Já as despesas geradoras de créditos na atividade comercial seriam todas aquelas necessárias à manutenção do estabelecimento comercial, e não apenas as relativas à aquisição dos produtos e embalagens a serem revendidos.

\footnotetext{
376 Idem, ibidem, p.117-118.

377 Nessa mesma linha, deveriam ser admitidos créditos relativos a pagamentos de juros sobre capital próprio o que era admitido até a Lei 10.865/04, que introduziu alterações nos arts. .... e .... das leis 10.637/2002 e 10.833/2003, respectivamente. A respeito do tema, confira-se Despesas com o Pagamento de Juros sobre Capital Próprio de ANAN Jr., Pedro e LATORRE, Juliana Grandino in PIS - Cofins questões atuais e polêmicas. São Paulo: Quartier Latin, 2005, p. 347-360.
} 
O que Marco Aurélio Greco denomina de dispêndios inerentes ao processo formativo da receita em muito se assemelha à conceituação que Aires Fernandino Barreto, ${ }^{378}$ investigando o ISS, confere às despesas: “são gastos com a própria atividade, realizados para que esta possa desenvolver-se e propiciar os proventos (receitas) à vista dos quais se a explora”. Mas, pronunciando-se sobre a nova Cofins, instituída pela Lei 10.833/2003, Aires F. Barreto entendeu que os insumos relativamente aos quais poderia ser calculado o crédito compensável da contribuição a pagar não poderiam se limitar aos gastos e despesas referentes ao serviço; em suas palavras, não poderiam se restringir às despesas que “"como o guizo do gato' ou o ‘sino da vaca' acompanha o serviço em todas as partes”, ${ }^{379}$ pois, fosse assim, a não-cumulatividade seria apenas parcial. E concluiu: não-cumulatividade plena só existe quando se autoriza a compensação de todos os gastos, direta e indiretamente necessários à prestação de serviços.

Para Sacha Calmon Navarro Coêlho e Misabel Derzi,

o direito de crédito não se restringe ao crédito físico, mas estende-se a todas as despesas (aquisições de bens e serviços) incorridas, pagas ou creditadas às pessoas jurídicas contribuintes, sejam elas correspondentes a insumos, bens do ativo fixo (locação ou aquisição), consumo (como energia elétrica) ou financeiras decorrentes de empréstimos, financiamentos e valor das contraprestações de operações de arrendamento de pessoa jurídica. Evidentemente, as despesas de qualquer natureza, intributáveis por serem estranhas ao campo constitucional de possível incidência das contribuições (como a remuneração de mão-de-obra paga à pessoa física), não gerarão direito ao crédito na apuração do tributo devido. ${ }^{380}$

A nosso ver, equiparar os insumos do PIS e da Cofins aos custos dedutíveis para IRPJ e CSLL seria igualar os pressupostos de fato receita e renda que, como demonstramos anteriormente, são distintos.

No mesmo equívoco incorreríamos se tentássemos equiparar os conceitos de insumos de IPI e ICMS, pois, como visto, receita não é o mesmo que operação.

\footnotetext{
378 Trabalho temporário e base de cálculo do ISS. Atividades comissionadas. Distinção entre ingressos e receitas. Revista Dialética de Direito Tributário, n. 90, p. 16, São Paulo: Dialética, março 2000.

379 A nova Cofins: primeiros apontamentos. Revista Dialética de Direito Tributário, n. 103, p. 8.

380 PIS/Cofins: direito de crédito... cit., p. 147-148.
} 
Se PIS e Cofins, como tributos incidentes sobre a circulação de riquezas, compatibilizam-se com a técnica não-cumulativa, o direito ao crédito deveria seguir um dos modelos de tributação sobre o valor agregado: crédito financeiro ou crédito físico, no sentido que tais expressões tinham, originalmente, para a legislação francesa, correspondendo o primeiro ao método de cálculo que permite o abatimento relativamente a todos os insumos, inclusive os bens do ativo e serviços e o segundo àquele em que os bens instrumentais e serviços não dão direito a crédito (ou não são computados para se encontrar o valor agregado em cada etapa de circulação de riqueza).

A legislação do PIS e da Cofins aproxima-se do crédito financeiro, pois permite sejam calculados créditos concernentes a máquinas, equipamentos e bens do ativo adquiridos para uso na fabricação de produtos destinados à venda, na prestação de serviços ou para locação a terceiros ${ }^{381}$ (art. 3. ${ }^{\circ}$, inc. VI, das Leis 10.637/2002 e 10.833/2003). Permite também sejam calculados créditos em relação a edificações e benfeitorias em imóveis de terceiros (art. 3. ${ }^{\circ}$, inc. VII, das Leis $10.637 / 2002$ e $10.833 / 2003 .^{382}$

Quanto à generalidade, o PIS e a Cofins não-cumulativos atingem toda a extensão dos planos vertical e horizontal, ${ }^{383}$ pois são cobrados na produção, no atacado e no varejo, abrangendo todos os bens e serviços.

Mas que dizer dos créditos calculados sobre itens que não são nem insumos nem bens instrumentais, e sim despesas ou custos, tais as despesas com arrendamento mercantil e, até a Lei 10.685/2004, as despesas financeiras?

Nesse ponto, a sistemática instituída pelas Leis 10.637/2002 e 10.833/2003 remete ao método aditivo, em que se calcula o valor agregado mediante a soma de quaisquer custos incorridos na produção do output. O mesmo ocorria com as despesas financeiras e juros sobre

381 A Lei 11.196/2005 incluiu o direito a crédito em relação a máquinas, equipamentos e bens do ativo fabricados para locação a terceiros.

382 No PIS (Lei 10.637/2002) referido crédito só é permitido quando os custos, inclusive com mão-de-obra, tenham sido suportados pelo locatário.

383 Cf. Alcides Jorge Costa "o imposto sobre o valor acrescido admite ainda três tipos segundo sua maior ou menor generalidade no plano vertical: cobrança no ciclo da produção, no da produção e atacado, e no da produção, no atacado e no varejo. No plano horizontal, o imposto sobre o valor acrescido pode ser global se abranger todos os bens e serviços, ou parcial em caso contrário" (ICM - Estrutura na Constituição e na lei complementar cit., p. 25). 
capital próprio que, até o advento da mencionada Lei 10.685/2004, ensejavam direito ao crédito.

Em suma, podemos afirmar que a legislação do PIS e da Cofins inspirou-se no modelo de imposto sobre o valor agregado que leva em conta o chamado crédito financeiro, pois admite o creditamento tanto de insumos como de bens do ativo fixo e serviços. E como o creditamento dos bens do ativo fixo é permitido conforme a depreciação (§ $1 .^{\circ}$ do art. $3 .^{\circ}$ ), assemelha-se, nesse ponto, ao IVA tipo renda.

Quanto ao método de cálculo, criou uma sistemática que mescla aspectos do tipo subtrativo, na variante tributo contra tributo, pois determina que o total dos créditos seja abatido da contribuição a pagar, com aspectos do método aditivo (apenas no que determina sejam calculados créditos relativos a determinados custos e despesas).

Note-se: essas conclusões serão válidas se entendermos que a não-cumulatividade do PIS e da Cofins é forma de arrecadação que visa facilitar sua administração, contribuir para a neutralidade e corrigir desequilíbrios na concorrência. Entendendo-se que se trata de sistemática de desoneração de determinados setores, não seria mesmo vincular-se a nenhum método de cálculo, pois não se trataria, efetivamente, de tributo sobre valor agregado.

\subsubsection{Créditos na isenção e na alíquota zero}

Vimos que, para o IPI e o ICMS, a isenção ou alíquota zero na aquisição de um insumo deveriam gerar o crédito, sob pena de restar prejudicada a não-cumulatividade, em virtude do efeito de recuperação. Analogamente, a isenção ou alíquota zero de um produto ou serviço não deveria determinar o estorno dos créditos relativos aos insumos tributados, pois a regra de reversão (ou mecanismo de regularização) é fator limitador da não-cumulatividade.

A legislação da Cofins (Lei 10.833/2003, art. 3. ${ }^{\circ}$, § 2. ${ }^{\circ}$, e, por remissão do art. 15, inc. II, também a do PIS) prevê que não dão direito a crédito nem o valor da mão-de-obra paga à pessoa física nem as despesas não sujeitas ao pagamento das contribuições, inclusive as isentas, nesse último caso (isenção), se o output estiver sujeito a alíquota zero, for isento ou não alcançado pelas contribuições. 
Art. 3. ${ }^{\circ}$, § $2 .^{\circ}$ Não dará direito a crédito o valor: I - de mão-de-obra paga a pessoa física; e II - da aquisição de bens ou serviços não sujeitos ao pagamento da contribuição, inclusive no caso de isenção, esse último quando revendidos ou utilizados como insumo em produtos ou serviços sujeitos à alíquota 0 (zero), isentos ou não alcançados pela contribuição. ${ }^{384}$

Fortes em que, no que pertine a isenções e alíquotas zero, a não-cumulatividade do PIS e da Cofins segue a do IPI, pois a CF/88 não indica nenhuma restrição ao creditamento nem determina qualquer estorno, Sacha Calmon Navarro Coelho e Misabel Derzi, pronunciando-se sobre o creditamento na entrada (na aquisição de insumos) extraem, desse dispositivo, que a legislação "concede crédito presumido expresso, no que tange às hipóteses de isenção" e "silencia em relação às alíquotas zero [...]”. ${ }^{385}$ Afirmam que esse silêncio é irrelevante para a parte da doutrina segundo a qual a isenção e a alíquota zero são equivalentes (Misabel Derzi, Paulo de Barros Carvalho, Roque Carrazza e outros). ${ }^{386}$ Também para os que, como Sacha Calmon Navarro Coêlho, entendem que alíquota zero é diferente da isenção, ${ }^{387}$ o crédito deve ser mantido, pois a CF/88 só determina o estorno do crédito, presumido ou real, se houver não-incidência nas aquisições e, ainda assim, apenas para o ICMS.

A redação do dispositivo é caprichosa. Dá a entender, à primeira vista, que o crédito será negado quando o produto ou serviço (output) ao qual se vincule o insumo (input) for isento, não tributado ou sujeito a alíquota zero.

Tratando do tema com profundidade, os mencionados autores observam que, na verdade, o inc. II do $\S 2 .^{\circ}$ do art. 3. ${ }^{\circ}$ da Lei 10.833/2003 diz que só não haverá crédito se o insumo for usado na produção de produto ou serviço igualmente isento ou não tributado ou

\footnotetext{
384 Inciso II com a redação dada pela Lei 10.865/04.

385 PIS/Cofins: direito de crédito nas entradas. Revista Dialética de Direito Tributário, n. 115, p. 145.

386 Para esses autores, não há sentido prever que da ocorrência do fato deve ser a prestação, mas ao determinar essa prestação, dizer que é nenhuma por faltarem base ou alíquota. Fortes em que a obrigação é sempre transitória - nasce para ser extinta - entendem absurda uma proposção normativa de uma obrigação sem credor, nem prestação, nem obrigado.

387 Pois representa incidência e existência do fato gerador.
} 
sujeito a alíquota zero. Daí concluírem que, “na hipótese inversa [produto final tributado], o insumo gera crédito, ainda que não tributado" ${ }^{388} \backslash$

Posteriormente, o art. 17 da Lei 11.033/2004, conversão da MP 206/2004, estabeleceu que “as vendas efetuadas com suspensão, isenção, alíquota zero ou não incidência da Contribuição para o PIS/Pasep e da Cofins não impedem a manutenção, pelo vendedor, dos créditos vinculados a essas operações”. Consequência disso é que, mesmo não havendo incidência na saída (seja por suspensão, isenção ou alíquota zero), o crédito do insumo será dedutível do valor de contribuição a pagar.

388 PIS/Cofins: direito de crédito nas entradas. Revista Dialética de Direito Tributário, n. 115, p. 153. 


\section{CONCLUSÕES}

O presente capítulo, à guisa de síntese, expõe sistematicamente as conclusões do presente estudo.

1. De acordo com Adam Smith, a riqueza produzida por uma nação é fonte de todos os tributos. Nesse sentido, considera-se, em economia, que os tributos incidem sobre o produto bruto nacional.

1.1. Considerando-se que a riqueza produzida por uma determinada nação ou será acumulada ou será consumida, é tradição afirmar, no direito tributário brasileiro, que existem três fontes de riqueza tributáveis: a riqueza produzida, a riqueza acumulada (poupada ou reinvestida) e a riqueza consumida.

2. O direito tributário colhe, de cada uma dessas fontes de riquezas, determinadas parcelas da realidade que, por revelarem capacidade contributiva, ensejam a instituição de tributos. Essas parcelas da realidade são denominadas pressupostos de fato dos impostos.

2.1. Os fatos geradores dos tributos referem-se a essas parcelas da realidade sob sua forma jurídica. Assim, em vez de instituir tributos sobre a riqueza produzida, o legislador tributário refere-se a tributos sobre a receita bruta; no lugar de abordar tributos sobre a riqueza acumulada, fala de tributos sobre o patrimônio; e, ao se referir aos tributos sobre a riqueza consumida, fala em tributos sobre operações de vendas e consumo.

2.2. Apesar de os fatos geradores qualificarem juridicamente as realidades tributárias, o aspecto econômico dos pressupostos de fato é relevante para identificar os diferentes tributos e evitar a instituição de mais de uma incidência sobre a mesma parcela da realidade.

3. O aspecto econômico dos pressupostos de fato foi o critério adotado pelo CTN para agrupar os impostos. A classificação do CTN, em linhas gerais, coincide com a tradicional repartição das fontes de riquezas tributáveis: patrimônio, renda e circulação de riquezas. 
3.1. No grupo dos impostos sobre o patrimônio e a renda, o CTN refere-se à riqueza acumulada (poupada ou reinvestida) e produzida. Já no grupo dos impostos sobre a produção e a circulação, o CTN aborda pressupostos de fato que dizem respeito à noção econômica de circulação, correspondente à riqueza produzida e lançada ao consumo, tradicionalmente associada à circulação de riquezas, enquanto fonte tributável.

4. A circulação econômica é noção ampla, que abrange operações em que haja duas pessoas e um bem, que pode ser usufruído por uma delas ou por ambas.

4.1. As operações de industrialização e distribuição são etapas elementares da circulação econômica, que compreende outras operações de circulação de riquezas, tais como operações de crédito, câmbio, seguros, etc.

4.2. A circulação de riquezas, como fonte tributável, abrange vários pressupostos de fato que evidenciam capacidade econômica dos contribuintes, os quais, juridicamente qualificados, podem figurar no aspecto material do fato gerador de diversos tributos. São exemplos desses pressupostos de fato os produtos, as mercadorias, os bens, os serviços; as operações de industrialização, de distribuição, de venda (ou prestação, no caso dos serviços); os contratos de crédito, câmbio e seguro, os títulos, valores mobiliários, as operações que ensejam sua circulação; e a contraprestação pelas referidas operações (faturamento e receita).

5. As contribuições sociais de seguridade social são espécies tributárias. Nas contribuições sociais, as parcelas da realidade que evidenciam capacidade contributiva são chamadas de materialidades econômicas.

5.1. Até a EC 20/98, as contribuições sociais de seguridade social podiam ter como materialidade econômica o faturamento. Após a EC 20/98, admite-se a incidência de contribuições sociais também sobre a receita.

5.2. Faturamento, receita e operações são categorias distintas, que representam diferentes parcelas da realidade. O faturamento é o produto das operações de venda mercantil e prestação de serviços. De acordo com a jurisprudência do STF, o faturamento pode ser compreendido como correspondente à receita proveniente das referidas operações. Por outro lado, o conceito de receita compreende, além das contraprestações advindas das operações de 
venda e prestação de serviços (faturamento), aquelas provenientes de outras operações e negócios da pessoa jurídica, tais os investimentos ou a cessão onerosa e temporária de bens e direitos a terceiros. Já as operações são os negócios e atividades da pessoa jurídica, cuja contraprestação é o faturamento ou a receita.

5.3. O faturamento e a receita ensejam a cobrança do PIS e da Cofins; as operações que dão origem ao faturamento ensejam a cobrança do IPI e do ICMS; as demais operações da pessoa jurídica ensejam a cobrança de variados tributos, v.g., o IOF.

6. O fato gerador e a base de cálculo são os critérios que a CF/88 indicou como aptos a distinguir as espécies tributárias. O binômio constitucional fato gerador + base de cálculo qualifica a realidade econômica tributável - isto é, qualifica o pressuposto de fato, nos impostos, e as materialidades econômicas, nas contribuições. Logo, o pressuposto de fato/materialidade econômica é relevante para a distinção dos tributos.

6.1. Sendo assim, o PIS e a Cofins incidentes sobre a receita equiparada ao faturamento (anteriores à EC 20/98, regidos pela Lei 9.718/98, designados PIS e Cofins cumulativos) e o PIS e a Cofins incidentes sobre a receita total (posteriores à EC 20/98, regidos pelas Leis 10.637/2002 e 10.833/2003, referidos como PIS e Cofins não-cumulativos) são contribuições distintas.

7. As materialidades econômicas das contribuições sociais de seguridade social, em alguns casos, coincidem com os pressupostos de fato de impostos. Diante disso, é possível classificar as contribuições sociais de seguridade social - incluindo o PIS e Cofins - de acordo com os grupos de impostos do CTN.

7.1. A materialidade econômica do PIS e da Cofins, a receita (equiparada ao faturamento, no PIS e na Cofins cumulativos; e correspondente à receita total, no PIS e na Cofins não-cumulativos) equivale à riqueza produzida pela pessoa jurídica que a aufere.

7.1.1 Receita é a riqueza produzida no ciclo de operações que promovem o giro da economia; é a riqueza produzida e lançada ao consumo que, portanto, integra a fonte de riqueza tributável tradicionalmente denominada circulação de riquezas. 
7.2. Tendo em vista que, ao agrupar no mesmo título os impostos sobre a produção e a circulação, o CTN teve em mira a circulação econômica, que abrange a produção, a circulação e o consumo das riquezas de um país - ou seja, a circulação de riquezas que o direito tributário indica como fonte reveladora de capacidade contributiva - o PIS e a Cofins, cumulativos e não-cumulativos, qualificam-se como contribuições de seguridade social incidentes sobre a produção e a circulação, ou seja, tributam a circulação de riquezas.

8. As operações de venda de mercadorias e de prestações de serviços são os pressupostos de fato mais tradicionais do grupo de impostos sobre a produção e a circulação (circulação de riquezas).

8.1. Os impostos incidentes sobre essas operações são denominados pela doutrina de tributos sobre vendas/consumo.

8.1.1. Em economia, tributos sobre vendas recaem sobre as vendas em si ou sobre elementos a elas incidentais, tais como as receitas delas provenientes. Economicamente, equiparam-se a tributos sobre o consumo porque, dada a tendência do mercado de buscar o preço de equilíbrio, vendedores e consumidores partilham o encargo de tributos que recaem sobre as receitas de vendas.

8.1.2. Em direito, um tributo é considerado incidente sobre o consumo quando sua estrutura viabilizar o repasse jurídico do respectivo encargo até o consumidor final e houver mecanismos jurídicos que regulem essa transferência do ônus tributário. A equiparação terminológica entre tributos sobre vendas e tributos sobre consumo decorre do caráter sinalagmático das operações de compra e venda: venda para um é consumo para outro; receita para um é despesa para outro.

9. Qualquer tipo de tributo enseja a translação econômica do respectivo encargo. Nos tributos sobre vendas/consumo, esse repasse econômico se opera por meio do preço; em tributos sobre o patrimônio (v.g., o IPTU), a translação econômica pode dar-se via preço ou por disposição contratual, não sendo tal repasse intrínseco à natureza do tributo.

9.1. O repasse jurídico do encargo tributário, por outro lado, só ocorre quando o pressuposto de fato ou a materialidade econômica do tributo revelar uma relação transacional 
subjacente à relação tributária, isto é, quando envolver uma dualidade de sujeitos e traduzir operação no âmbito da qual tal transferência possa ocorrer - esse o chamado pressuposto de fato / materialidade econômica bilateral.

9.2. Presente a bilateralidade, a translação jurídica se opera e é regulada por meio de instrumentos igualmente jurídicos. A inclusão mandatória do valor do tributo no preço final e a não-cumulatividade são exemplos desses instrumentos jurídicos de translação adiante do encargo tributário.

10. O PIS e a Cofins não-cumulativos não são tributos sobre o consumo, pois não comportam a translação jurídica do encargo tributário. Sua materialidade econômica, a receita, não é bilateral; é unilateral, pois depende apenas da perspectiva daquele que a aufere. A receita advém de operações - essas, sim, bilaterais -, mas delas se distingue, pois representa a contrapartida de tais operações; representa a contrapartida pela ocorrência do fato, mas não o fato em si.

11. Além disso, o art. 195 da CF/88 indicou como contribuintes financiadores da seguridade social o trabalhador, os demais segurados da previdência social, o importador de bens ou serviços e os agentes econômicos (empregador, empresa e entidade a ela equiparada) que produzem riquezas, mas não o consumidor de tais riquezas. Portanto, apesar de tributarem a circulação de riquezas, que engloba a riqueza produzida e lançada ao consumo, PIS e Cofins visam a atingir a riqueza produzida, mas não a riqueza consumida.

12. A não-cumulatividade não se presta apenas a viabilizar o repasse jurídico do encargo tributário ao consumidor final. A sistemática foi concebida no âmbito dos tributos sobre vendas/consumo para contornar os inconvenientes econômicos da tributação plurifásica cumulativa (em cascata), a saber: prejuízos à concorrência, materializados na tendência de os agentes econômicos se agruparem em processo de integração vertical visando a reduzir a extensão do ciclo produtivo e, consequentemente, o custo tributário; prejuízos à balança comercial, pois o peso maior do tributo torna o produto exportado mais caro e, portanto, com menores possibilidades de concorrer em mercados internacionais; e prejuízos à administração do tributo, pois quanto maior o número de contribuintes, mais cara e trabalhosa é a fiscalização. 
12. Para entender a não-cumulatividade do PIS e da Cofins, é preciso compreender os tributos sobre vendas/consumo, nos quais foi concebida tal sistemática.

12.1. Os tributos sobre vendas/consumo podem ser arrecadados por diversas técnicas, cada uma com suas vantagens e desvantagens. No início, eram arrecadados por técnica plurifásica cumulativa, ou seja, incidiam em todas as fases do ciclo econômico, sobrepondo-se nas diversas etapas de circulação e acarretando um aumento na base tributável, chamado efeito cumulativo.

13. Para afastar os malefícios da tributação plurifásica cumulativa, a França instituiu a TVA - taxe sur la valeur ajoutée, cuja principal vantagem é manter o nível de arrecadação, espraiando os encargos tributários pela cadeia de circulação econômica. Produz, por meio de diversas incidências, aquilo que seria normalmente arrecadado como se houvesse uma só incidência, e contorna os efeitos perversos para a economia da tributação em cascata.

13.1. A tributação sobre o valor agregado pode ser efetivada por diversos métodos: no aditivo, somam-se os fatores de produção que agregam valor ao output final, aplicando-se a alíquota sobre esse somatório; no subtrativo, consideram-se os montantes das vendas e das compras num dado período e calcula-se o tributo ou aplicando-se a alíquota respectiva sobre a diferença entre as referidas vendas e compras num dado período (método subtrativo base sobre base); ou, em operações paralelas e simultâneas, aplica-se a alíquota sobre as vendas totais, aplica-se a alíquota sobre as compras e encontra-se o valor do tributo a partir de uma outra operação, subtraindo-se do subtotal encontrado na primeira operação o montante encontrado na segunda (método tributo sobre tributo).

13.2. No imposto sobre o valor agregado, os insumos (matéria-prima, material de embalagem e materiais secundários) sempre serão deduzidos para se encontrar o valor a pagar. Mas há três formas de encarar a dedução dos ativos que não integram fisicamente o produto final: se for permitida sua dedução integral, o IVA será tipo consumo; se for vedada, será tipo produto bruto - hipótese em que o tributo será cumulativo; se for permitida na proporção da depreciação, será tipo renda.

13.3. As expressões crédito físico e financeiro devem ser usadas para designar, de forma sucinta, as deduções relativas aos bens que se incorporem fisicamente à produção e 
àquelas relativas aos bens instrumentais (bens do ativo, materiais secundários, instrumentos de produção).

14. No Brasil, IPI e ICMS são considerados impostos sobre o consumo porque seu pressuposto bilateral (operações) permite o repasse do encargo tributário até o consumidor final, cuja capacidade contributiva visam a atingir.

14.1. A não-cumulatividade é o mecanismo jurídico por meio do qual ocorre a translação jurídica do encargo tributário no IPI e no ICMS. Não obstante, dadas as diversas restrições ao creditamento, esses impostos têm alto resíduo cumulativo e oneram o setor produtivo.

14.2. O método de arrecadação do IPI e do ICMS é o indireto, na variante imposto contra imposto. Os créditos permitidos são os físicos e os financeiros e há normas do ICMS, como a que prevê a dedução dos créditos relativos aos investimentos em 48 meses, que o aproximam de um tributo sobre o valor agregado do tipo renda.

15. Adotando-se a distinção inclusiva de Humberto Ávila, segundo a qual uma mesma norma pode apresentar características de princípio ou de regra, a não-cumulatividade será princípio quando viabilizar a neutralidade e a tributação conforme a capacidade contributiva do consumidor. Será regra quando representar mera técnica de arrecadação.

16. Apesar de PIS e Cofins incidirem sobre a circulação de riquezas, sua nãocumulatividade não visa à translação jurídica do tributo para o consumidor. Há diversas formas de entender a não-cumulatividade dessas contribuições:

16.1. Entendendo-se que a passagem da sistemática cumulativa para a nãocumulativa não representou aumento de carga tributária - conclusão que decorreria da presunção de que a alíquota de 3,65\% cumulativa equivale à alíquota de 9,25\% nãocumulativa -, a não-cumulatividade do PIS e da Cofins pode ser entendida como técnica de arrecadação que contribui para a neutralidade concorrencial da tributação.

16.2. Caso se entenda que a mudança da sistemática de arrecadação do PIS e da Cofins implicou aumento da carga tributária e sua redistribuição entre os setores de atividades econômicas, a não-cumulatividade daquelas contribuições deve ser entendida como 
sistemática de desoneração de certos setores e deveria estar vinculada aos princípios da isonomia e da capacidade contributiva.

17. Não há, portanto, um significado único de não-cumulatividade no texto constitucional. Enquanto a não-cumulatividade do IPI e do ICMS é instrumento com o qual se visa atingir a capacidade contributiva dos consumidores e tornar o tributo neutro, não perturbando a concorrência, a não-cumulatividade do PIS e da Cofins pode ter um dos significados expostos acima.

18. A não-cumulatividade do PIS e da Cofins decorre diretamente da lei ordinária, e não da CF/88, como é o caso da não-cumulatividade do IPI e do ICMS.

18.1. O único fator de discrímen de que o legislador ordinário pode se valer para dizer se determinado contribuinte ou determinada receita auferida por qualquer contribuinte será apurada de forma cumulativa ou não-cumulativa é o setor de atividade econômica (CF/88, art. 195, § 9. ${ }^{\circ}$.

19. No art. 195, § 12, a expressão setores de atividade econômica significa as diferentes atividades do setor público e do setor privado que movimentam a economia. Equipara-se, nesse sentido, à atividade econômica da empresa, assim considerada como a atividade criadora de riquezas que se manifesta na empresa, mas que com ela não se confunde.

19.1. É legítima a indicação de que o PIS e a Cofins serão não-cumulativos para determinadas atividades, mas é ilegítima a discriminação em virtude de fatores como o regime de apuração do lucro real e a forma societária adotada pela pessoa jurídica.

19.2. A discriminação em função do setor da atividade econômica, para atender ao princípio da igualdade, precisa atender a uma finalidade constitucional, sob pena de ser arbitrária.

20. Sendo a não-cumulatividade do PIS e da Cofins é diferente da nãocumulatividade do IPI e do ICMS, seu método de arrecadação não coincide com o daqueles tributos, nem se identifica integralmente com os demais métodos de implementação da nãocumulatividade (método aditivo e método subtrativo, variante base contra base). 
20.1. A não-cumulatividade do PIS e da Cofins opera-se por meio da concessão de créditos calculados em relação a determinados valores que representam insumos, bens instrumentais, custos ou despesas da atividade econômica selecionada para ser nãocumulativa, sendo irrelevante ter ou não ter havido incidência das contribuições sobre tais valores na etapa anterior de circulação da riqueza. O valor a pagar é apurado a partir da aplicação da alíquota sobre a base de cálculo, deduzindo-se, em seguida, os referidos créditos.

21. Não vislumbramos, nos dispositivos das leis 10.637/02 e 10.833/03 que indicam as receitas e os contribuintes sujeitos à apuração cumulativa do PIS e da Cofins nenhuma relação com qualquer dos significados que a não-cumulatividade daquelas contribuições possa ter: não há critério que indique que os setores para os quais as contribuições são cumulativas são aqueles em que a arrecadação seja mais difícil ou onde haja maior concentração vertical. Também não há indicativo de que a discriminação dos setores sujeitos a cumulatividade e dos setores sujeitos à não-cumulatividade daquelas contribuições se oriente pela capacidade contributiva.

20.1. A não-cumulatividade do PIS e da Cofins poderia ter servido de instrumento para realização de tais finalidades (otimização da arrecadação, neutralidade concorrencial e tributação conforme a capacidade contributiva). Todavia, não é o que se verifica na prática. 


\section{BIBLIOGRAFIA}

ANAN JR., Pedro; LATORRE, Juliana Grandino. Despesas com o pagamento de juros sobre capital próprio. In: PEIXOTO, Marcelo Magalhães; FISCHER, Octávio Campos (coord.). PIS-Cofins: questões atuais e polêmicas. São Paulo: Quartier Latin, 2005.

ASSIS JR., Milton Carmo. A não-cumulatividade do PIS e da Cofins. Revista Tributária e de Finanças Públicas, n. 64, p. 106-120, São Paulo: Revista dos Tribunais, [s.d.].

ATALIBA, Geraldo. Hipótese de incidência tributária. 6. ed., 6. tir. São Paulo: Malheiros, 2005.

ATALIBA, Geraldo; GIARDINO, Cléber. PIS - Exclusão do ICM de sua base de cálculo. Revista de Direito Tributário, n. 35, p. 151-162, jan.- mar. 1986.

ÁVILA, Humberto. A teoria dos princípios e o direito tributário. Revista Dialética de Direito Tributário, São Paulo: Dialética, n. 125, p. 33-49, especialmente p. 39, fev. 2006

. Contribuição social sobre o faturamento. Cofins. Base de cálculo. Distinção entre receita e faturamento. Jurisprudência do Supremo Tribunal Federal. Revista Dialética de Direito Tributário, São Paulo: Dialética, n. 107, p. 95, ago. 2004.

—. Sistema constitucional tributário. 3. ed. rev. e atual. São Paulo: Saraiva, 2006.

. Teoria dos princípios. 8. ed. São Paulo: Malheiros, 2008.

BALEEIRO, Aliomar. Limitações constitucionais ao poder de tributar. Atualizado por Misabel Abreu Machado Derzi. 7. ed. Rio de Janeiro: Forense, 1997.

BARRETO, Aires Fernandino. Trabalho temporário e base de cálculo do ISS. Atividades comissionadas. Distinção entre ingressos e receitas. Revista Dialética de Direito Tributário, São Paulo: Dialética, n. 90, p. 16, mar. 2000. 
BASTO, José Xavier. A adopção do sistema comum europeu de Imposto sobre o Valor Acrescentado (IVA) em Portugal. In: SARAIVA FILHO, Oswaldo Othon de Pontes; VASQUES, Sérgio; GUIMARÃES, Vasco Branco (org.). IVA para o Brasil: contributos para a reforma da tributação do consumo no Brasil. Belo Horizonte: Fórum, 2007.

BERLIRI, Antonio. L'imposta sul valore aggiunto. Milão: Giuffrè, 1971.

Boletim Informe-SF. Secretaria para Assuntos Fiscais - SF, n. 7, 2000.

BONILHA, Paulo Bergstrom. IPI e ICM fundamentos da técnica não-cumulativa. São Paulo: Resenha Tributária, 1979.

BORGES, José Souto Maior. As contribuições sociais (PIS/Cofins) e a jurisprudência do STF. Revista Dialética de Direito Tributário, São Paulo: Dialética, n. 118, p. 76, jul. 2005.

BORGES, José Souto Maior. Teoria geral da isenção tributária, 3. ed. São Paulo: Malheiros, 2001.

BRAZUNA, Luis R. Neutralidade tributária e uso da tributação para prevenir desequilíbrios da concorrência. 2008. Dissertação (Mestrado) - USP, São Paulo.

BRITO, Edvaldo. Cofins e PIS/Pasep: conceito de faturamento e de receita bruta, II - CPMF: questionamentos jurídicos. Revista Dialética de Direito Tributário, São Paulo: Dialética, n. 43, p. 33, abr. 1999.

CALIENDO, Paulo. A Cofins nas instituições financeiras: da aplicação do princípio da neutralidade fiscal. In: PEIXOTO, Marcelo Magalhães; FISCHER, Octávio Campos (coord.). PIS-Cofins: questões atuais e polêmicas. São Paulo: Quartier Latin, 2005.

CANADO, Vanessa. As regras-matrizes de incidência tributária da Contribuição para o Financiamento da Seguridade Social (Cofins) nos regimes "cumulativo”, "nãocumulativo", de "incidência monofásica" e de "substituição tributária”, previstos na Lei Complementar n. 70/91 e nas Leis n. 9.178/98, n. 10.147/00, n. 10.485/02, n. 10.560/02 e n. 10.833/03. Dissertação (Mestrado). 2008 - PUC, São Paulo. 
CANTO, Gilberto de Ulhôa. Causa da obrigação tributária. Temas de direito tributário. Rio de Janeiro: Alba, 1964. v. 1.

CANTO, Gilberto de Ulhôa. IPI. Não-cumulatividade. Direito à compensação de créditos referentes a matéria-prima isenta. Disciplina diferente da que prevalece atualmente em relação ao ICMS. Isenção, natureza e efeitos jurídicos. Direito tributário aplicado Pareceres. São Paulo: Forense Universitária, 1992.

CARRAZZA, Roque Antônio. ICMS - Inconstitucionalidade da inclusão de seu valor, em sua própria base de cálculo. Revista Dialética de Direito Tributário, São Paulo: Dialética, n. 23, p. 96-98, ago. 2007.

CARRAZZA, Roque. ICMS. 5. ed. rev. atual. São Paulo: Malheiros, 1999.

CARVALHO, Paulo de Barros. Curso de direito tributário. 17. ed. São Paulo: Saraiva, 2005.

—. Isenções tributárias do IPI, em face do princípio da não-cumulatividade. Revista Dialética de Direito Tributário, São Paulo: Dialética, v. 33, p. 166, jun. 1998

COELHO, Sacha Calmon Navarro. Comentários à Constituição de 1988 - Sistema Tributário. $6^{\text {a }}$. ed. Rio de Janeiro: Forense, 1995.

—. Curso de direito tributário: (comentários à Constituição e ao Código tributário nacional, artigo por artigo). Rio de Janeiro: Forense, 2001.

. O IVA brasileiro. In: SARAIVA FILHO, Oswaldo Othon de Pontes; VASQUES, Sérgio; GUIMARÃES, Vasco Branco (Org.). IVA para o Brasil: contributos para a reforma da tributação do consumo no Brasil. Belo Horizonte: Fórum, 2007.

COELHO, Sacha Calmon Navarro. Geraldo Ataliba - Cientista do direito - Reflexões sobre a hipótese de incidência dos tributos - Substitutos e responsáveis tributários no direito brasileiro. Revista Dialética de Direito Tributário, São Paulo: Dialética, n. 8, p. 112, maio 1996. 
COELHO, Sacha Calmon Navarro; MANEIRA, Eduardo; SANTIAGO, Igor Mauler. Inconstitucionalidade da Lei 9.718/98, na parte em que alargou a base de cálculo da Cofins - uma abordagem de direito intertemporal. Revista Dialética de Direito Tributário, São Paulo: Dialética, n. 73, p. 126, out. 2001.

CORRÊA, Rodrigo Arantes Barcellos. Os contratos atípicos interempresariais e os contratos de Shopping Center. 2008. Dissertação (Mestrado) - USP, São Paulo.

COSCIANI, Cesare. El impuesto al valor agregado. Buenos Aires: Depalma, 1969.

COSTA, Alcides J. ICM - Estrutura na Constituição e na lei complementar. São Paulo: Irmãos Milesi, 1977.

COSTA, Alcides J. Imposto de vendas e consignações: análise dos sistemas de arrecadação. Separata da Revista de Administração e Empresas da Fundação Getúlio Vargas, São Paulo: FGV, v. 2, n. 6, p. 55, passim, [s.d.].

COSTA, Alcides Jorge. Algumas idéias sobre uma reforma do sistema tributário brasileiro. In: NOGUEIRA, Ruy Barbosa (Coord.). Direito tributário atual. v. 7/8. São Paulo: Resenha Tributária, 1987.

DERZI, Misabel de Abreu Machado. Direito tributário, direito penal e tipo. 2. ed. rev. e atual. São Paulo: Revista dos Tribunais, 2007.

DERZI, Misabel de Abreu Machado; COÊLHO, Sacha Calmon Navarro. ICMS - Nãocumulatividade e temas afins. In: MARTINS, Ives Gandra da Silva (coord.) [et al]. Pesquisas Tributárias. Nova Série; 10 - O princípio da não-cumulatividade. São Paulo: Centro de Extensão Universitária/Ed. Revista dos Tribunais, 2004.

— - - PIS/Cofins: direito de crédito nas entradas e saídas isentas ou com alíquota zero. Revista Dialética de Direito Tributário, São Paulo: Dialética, n. 115, p. 143-154, abr. 2005.

DERZI, Misabel de Abreu Machado; SANTIAGO, Igor Mauler. A harmonização dos IVAs do Brasil para o desenvolvimento produtivo. In: SARAIVA FILHO, Oswaldo Othon de 
Pontes; VASQUES, Sérgio; GUIMARÃES, Vasco Branco (Org.). IVA para o Brasil: contributos para a reforma da tributação do consumo no Brasil. Belo Horizonte: Fórum, 2007.

DI PIETRO, Juliano. Repartição das receitas tributárias. In: CONTI, José Maurício (Org.). Federalismo fiscal. Barueri: Manoele, 2004.

DONATO, Maria Antonieta Zanardo. Proteção ao consumidor: conceito e extensão. São Paulo: RT, 1994.

DÓRIA, Roberto Sampaio. Princípios constitucionais tributários e a cláusula due process of law. Tese (Concurso à livre docência da Cadeira de Direito Financeiro da Faculdade de Direito da USP). São Paulo, 1964.

DUE, John F. Sales taxation. Londres: Routledge \& Kegan Paul, 1957.

ELALI, André. O federalismo fiscal brasileiro e o Sistema Tributário Nacional. São Paulo: MP, 2005.

FALCÃO, Amilcar. Interpretação e integração da lei tributária. Revista de Direito Administrativo, FGV, n. 40, p. 32, abr.-jun. 1955.

FALCÃO, Maurin Almeida. Da tributação cumulativa ao Imposto sobre o Valor Agregado: o percurso notável da inovação tributária do Século XX. In: SARAIVA FILHO, Oswaldo Othon de Pontes; VASQUES, Sérgio; GUIMARÃES, Vasco Branco (org.). IVA para o Brasil: contributos para a reforma da tributação do consumo no Brasil. Belo Horizonte: Fórum, 2007.

FERREIRA, Júlio de Castilhos. A não-cumulatividade do PIS/Pasep e da Cofins. In: PAULSEN, Leandro (Coord.) et al. Não-cumulatividade do PIS/Pasep e da Cofins. São Paulo: IOB Thompson; Porto Alegre: Instituto de Estudos Tributários, 2004.

FISCHER, Octávio Campos. A contribuição ao PIS. São Paulo: Dialética, 1999. 
. PIS-Cofins, não cumulatividade e a Emenda Constitucional n. 42/03. In: PEIXOTO, Marcelo Magalhães; FISCHER, Octávio Campos (coord.). PIS-Cofins: questões atuais e polêmicas (a parte que não está em itálico é um subtítulo). São Paulo: Quartier Latin, 2005.

FRANCISCO NETO, João. Evolução Histórica dos Tributos. 2005. Dissertação (Mestrado) USP, São Paulo.

GRECO, Marco Aurélio. Contribuições (uma figura “sui generis”). São Paulo: Dialética, 2000.

—. Não-cumulatividade no PIS e na Cofins. In: PAULSEN, Leandro (Coord.) et al. Nãocumulatividade do PIS/Pasep e da Cofins. São Paulo: IOB Thompson; Porto Alegre: Instituto de Estudos Tributários, 2004.

. Cofins na Lei n. 9.718/98 - variações cambiais e regime de alíquota acrescida. Revista Dialética de Direito Tributário n. 50, p. 131.

—. Repetição de Indébito. In: MARTINS, Ives Gandra da Silva (Coord.); et al. Caderno de Pesquisas Tributárias, São Paulo: Resenha Tributária, n. 8, p. 282, 1983.

GUIMARÃES, Vasco Branco. A tributação do consumo no Brasil: uma visão européia. In: ; SARAIVA FILHO, Oswaldo Othon de Pontes; VASQUES, Sérgio (Org.). IVA para o Brasil: contributos para a reforma da tributação do consumo no Brasil. Belo Horizonte: Fórum, 2007.

HART, Herbert Lionel Adolphus. O conceito de direito. 3. ed. Lisboa: Fundação Calouste Gulbenkian (nas oficinas de Espaço 2 Gráfico), 2001.

LAURÉ, Maurice. La Taxe sur la Valeur Ajoutée. Paris: Recueil Sirey, 1952.

MACHADO, Hugo de Brito. Virtudes e defeitos da não-cumulatividade. In: MARTINS, Ives Gandra da Silva (Coord.) et al. Pesquisas tributárias - Nova Série - n. 10. O princípio da não-cumulatividade. São Paulo: Centro de Extensão Universitária/Revista dos Tribunais, 2004, p. 91. 
MANEIRA, Eduardo. Base de cálculo presumida. 2002. Tese (Doutorado) - Belo Horizonte: UFMG .

MARTINS, Alessandra. A admissibilidade de uma cláusula geral antiabuso em sede de IVA. In: SARAIVA FILHO, Oswaldo Othon de Pontes; VASQUES, Sérgio; GUIMARÃES, Vasco Branco (Org.). IVA para o Brasil: contributos para a reforma da tributação do consumo no Brasil. Belo Horizonte: Fórum, 2007.

MARTINS, Natanael. O Conceito de Insumos na Sistemática Não-Cumulativa do PIS e da Cofins. In: PEIXOTO. Marcelo Magalhães; FISCHER, Octávio Campos (coord.). PISCofins: questões atuais e polêmicas. São Paulo: Quartier Latin, 2005.

MELO, José Eduardo Soares de. Contribuições sociais no sistema tributário. 4. ed. rev., atual. e ampl. São Paulo: Malheiros, 2003.

; LIPPO, Luiz Francisco. A não-cumulatividade tributária (ICMS, IPI, ISS, PIS e Cofins). 3. ed. São Paulo: Dialética, 2008.

MINATEL, José Antônio. Conteúdo do conceito de receita e regime jurídico para sua tributação. 2005. Tese (Doutorado) - PUC, São Paulo.

MORAES, Bernardo Ribeiro de. Compêndio de direito tributário. 4. ed. Rio de Janeiro: Forense, 1995.

MOSQUERA, Roberto Quiroga. Renda e proventos de qualquer natureza. São Paulo: Dialética, 1996.

Novo dicionário Aurélio da língua portuguesa, 2. ed. Rio de Janeiro: Nova Fronteira, 1986.

OLIVEIRA, José Marcos Domingues de. Capacidade contributiva. Rio de Janeiro: Renovar, 1998.

OLIVEIRA, Ricardo Mariz de. Aspectos relacionados à “não-cumulatividade” da cofins e da contribuição ao PIS. In: PEIXOTO, Marcelo Magalhães; FISCHER, Octávio Campos (coord.). PIS-Cofins: questões atuais e polêmicas. São Paulo: Quartier Latin, 2005. 
OLIVEIRA, Ricardo Mariz de. O conceito de receita como hipótese das contribuições para a seguridade social (para efeitos da Cofins e da Contribuição ao PIS). Repertório IOB de Jurisprudência, n. 1, caderno 1, p. 20-43, 2001.

PINTO, Miguel Silva. O combate à fraude ao Imposto sobre o Valor Acrescentado: um desafio para a União Européia. In: PEIXOTO, Marcelo Magalhães; FISCHER, Octávio Campos (Coord.). IVA para o Brasil: contributos para a reforma da tributação do consumo no Brasil. Belo Horizonte: Fórum, 2007.

PONTES, Helenilson Cunha. O principio da proporcionalidade e o direito tributário brasileiro: hipóteses de aplicação. Tese (Doutorado). São Paulo (USP), 1999.

ROCHA, J. Tavares. Vendas e consignações. Rio de Janeiro: [s.n.], 1951.

ROCHA, Valdir de Oliveira. Determinação do montante do tributo: quantificação, fixação e avaliação. 2. ed. São Paulo: Dialética, 1995.

SANT’ANNA, Carlos Soares. A sistemática do PIS e da Cofins não-cumulativos para as empresas de extração mineral. In: PEIXOTO, Marcelo Magalhães; FISCHER, Octávio Campos (coord.). PIS-Cofins: questões atuais e polêmicas. São Paulo: Quartier Latin, 2005.

SANTIAGO, Igor Mauler. Código Tributário Nacional - Arts. 165 a 169. In: PEIXOTO, Marcelo Magalhães; LACOMBE, Rodrigo Santos Masset. Comentários ao Código Tributário Nacional. 2. ed. rev. e ampl. São Paulo: MP, 2008.

; LOBATO, Valter. Análise dos arts. 10, XI, e 15, V, da Lei 10.833/2003 Manutenção da Cofins e do PIS cumulativos para contratos de consórcio, de construção por empreitada e de fornecimento, a preço determinado, de bens e serviços, celebrados antes de 31 de outubro de 2003. In: PEIXOTO, Marcelo Magalhães; FISCHER, Octávio Campos (coord.). PIS-Cofins: questões atuais e polêmicas. São Paulo: Quartier Latin, 2005. 
SCHOUERI, Luis Eduardo. Discriminação de competências e competência residual. In: SCHOUERI, Luis Eduardo; ZILVETI, Fernando Aurélio (Coord.). Estudos em homenagem a Brandão Machado. São Paulo: Dialética, 1998

- Imposto de Renda e o comércio eletrônico. In: ; COSTA, Alcides Jorge (Coord.). Direito tributário atual. V. 16 - São Paulo: Dialética, 2001, p. 146-60. . Normas tributárias indutoras e intervenção econômica. São Paulo: Forense, 2005.

SHOUP, Carl. Value Added Taxation in Developing Countries, Washington: Malcolm Gillis, Carl S. Shoup, Gerardo P. Sicat, s/d., p. 8-9.

SILVA, Ives Gandra Martins; FERNANDES, Edson Carlos. Não-cumulatividade do PIS e da Cofins - Implicações contábil, societária e fiscal. São Paulo: Quartier Latin, 2007.

SILVA, Virgílio Afonso da. Princípios e regras: mitos e equívocos acerca de uma distinção. Revista Latino-Americana de Estudos Constitucionais, n. 1, p. 610-612, 2003.

SMITH, Adam. A riqueza das nações. São Paulo: Martins Fontes, 2003. v. 2.Tradução de Alexandre Amaral Rodrigues e Eunice Ostrensky.

SOUSA, Rubens Gomes de. A tributação das vendas. Série Prática Fiscal n. 1. O imposto sobre Vendas e Consignações no Sistema Tributário Brasileiro. Rio de Janeiro: Edições Financeiras, 1956.

SOUZA, Fátima Fernandes Rodrigues de. O princípio da não-cumulatividade. In: MARTINS, Ives Gandra da Silva (Coord.); et al. Pesquisas tributárias - Nova Série - n. 10. O princípio da não-cumulatividade. São Paulo: Centro de Extensão Universitária/Revista dos Tribunais, 2004.

; SILVA, Ives Gandra Martins da. A não-cumulatividade das contribuições: PIS/Pasep e Cofins. In: PAULSEN, Leandro (Coord.). Não-cumulatividade do PIS/Pasep e da Cofins. São Paulo: IOB Thompson; Porto Alegre: Instituto de Estudos Tributários, 2004. 
SULLIVAN, Clara K. The tax on value added. Nova Iorque e Londres: Columbia University Press, 1959, 1965.

TEIXEIRA, Alessandra Machado Brandão. A tributação sobre o consumo de bens e serviços. Belo Horizonte: Mandamentos, 2002.

TIPKE, Klaus. Princípio de igualdade e idéia de sistema no direito tributário. In: MACHADO, Brandão; SCHOUERI, Luis Eduardo; ZILVETI, Fernando Aurélio (Coord.). Direito tributário: Estudos em homenagem ao Prof. Ruy Barbosa Nogueira. São Paulo: Dialética, 1998.

TOMÉ, Fabiana Del Padre. Natureza jurídica da “não-cumulatividade” da contribuição ao PIS/Pasep e da Cofins: conseqüências e Aplicabilidade. In: PEIXOTO, Marcelo Magalhães; FISCHER. Octávio Campos (Coord.). PIS-Cofins: questões atuais e polêmicas. São Paulo: Quartier Latin, 2005.

TÔRRES, Heleno Taveira. Monofasia e não-cumulatividade das contribuições ao PIS e à Cofins no setor de petróleo (refinarias). In: PAULSEN, Leandro (Coord.) et al. Nãocumulatividade do PIS/Pasep e da Cofins. São Paulo: IOB Thompson; Porto Alegre: Instituto de Estudos Tributários, 2004.

. O IVA na experiência estrangeira e a tributação das exportações no direito brasileiro. In: SARAIVA FILHO, Oswaldo Othon de Pontes; VASQUES, Sérgio; GUIMARÃES, Vasco Branco (Org.). IVA para o Brasil: contributos para a reforma da tributação do consumo no Brasil. Belo Horizonte: Fórum, 2007.

TORRES, Ricardo Lobo. A não-cumulatividade no PIS/Cofins. In: PEIXOTO, Marcelo Magalhães; FISCHER. Octávio Campos (Coord.). PIS-Cofins: questões atuais e polêmicas. São Paulo: Quartier Latin, 2005.

. Curso de direito financeiro e tributário. 11. ed. Rio de Janeiro: Renovar, 2004.

. É possível a criação do IVA no Brasil? In: SARAIVA FILHO, Oswaldo Othon de Pontes; VASQUES, Sérgio; GUIMARÃES, Vasco Branco (Org.). IVA para o Brasil: 
contributos para a reforma da tributação do consumo no Brasil. Belo Horizonte: Fórum, 2007.

. O IVA no direito comparado. In: MARTINS, Ives Gandra da Silva (coord.); BARRETO, Aires Fernandino (colab.) [et al]. Pesquisas Tributárias. Nova Série; 10 O princípio da não-cumulatividade. São Paulo: Centro de Extensão Universitária/Ed. Revista dos Tribunais, 2004.

VALADÃO, Marcos. Comparative analysis of the Value Added Tax (VAT) and Retail Sales Tax (RST): a contribution to tax reform studies in the U.S. In: SARAIVA FILHO, Oswaldo Othon de Pontes; VASQUES, Sérgio; GUIMARÃES, Vasco Branco (Org.). IVA para o Brasil: contributos para a reforma da tributação do consumo no Brasil. São Paulo: Quartier Latin, 2007.

VANONI, Ézio. Natureza e interpretação das leis tributárias. Tradução de Rubens Gomes de Sousa. Rio de Janeiro: Edições Financeiras, [s.d.].

VARSANO, Ricardo. A Evolução do Sistema Tributário Brasileiro ao Longo do Século: Anotações e Reflexões para Futuras Reformas. IPEA - Instituto de Pesquisas Econômicas Aplicadas. Texto para Discussão n. 405 - Rio de Janeiro, 1996, p. 8. Disponível em: <http://www.ipea.gov.br/pub/td/1996/td_0405.pdf>. Acesso em: 18 jan. 2008.

VOGEL, Klaus. Tributação da renda mundial. Cadernos de Direito Tributário e Finanças Públicas, São Paulo: Revista dos Tribunais, v. 2, n. 7, p. 133-43, especialmente p. 134, abr.-jun. 1994.

WALD, Alexandre, NISHIOKA, Alexandre e MORAES, Allan. O aspecto temporal da hipótese de incidência das contribuições ao PIS e Cofins e as receitas não auferidas em virtude de inadimplemento. In: PEIXOTO, Marcelo Magalhães; FISCHER. Octávio Campos (Coord.). PIS-Cofins: questões atuais e polêmicas. São Paulo: Quartier Latin, 2005.

YAMASHITA, Douglas. Discriminação de Situações Sujeitas às Sistemáticas Cumulativa ou Não-Cumulativa do PIS e da Cofins: Limitações Constitucionais. In: COELHO, Sacha 
Calmon Navarro (Coord.). Contribuições para a Seguridade Social. São Paulo: Quartier Latin, 2007.

ZILVETI, Fernando A. Variações sobre o princípio da neutralidade no direito tributário internacional. Direito Tributário Atual, n. 19, São Paulo: Dialética e IBDT, 2005. 


\section{RESUMO}

A presente dissertação se divide em cinco capítulos. No primeiro, abordamos as fontes de riqueza tributáveis e o agrupamento dos impostos conforme a classificação do CTN, que leva em conta o aspecto econômico de seus pressupostos de fato. Tendo analisado o conceito econômico de circulação, identificamos, no grupo de impostos sobre produção e a circulação, diversos pressupostos de fato relacionados à circulação de riquezas como fonte tributável. O segundo capítulo trata da fonte de riqueza alcançada pelo PIS e pela Cofins não-cumulativos, que são objeto do presente estudo. Tendo em vista que a CF/88 indicou as materialidades econômicas sobre as quais a União pode instituir contribuições sociais de seguridade social, entendemos possível qualificá-las de acordo com os grupos de impostos do CTN. Após analisar sua materialidade econômica (a receita), concluímos as referidas contribuições podem ser classificadas como incidentes sobre a produção e a circulação, ou seja, sobre a circulação de riquezas. Por serem contribuições incidentes sobre a circulação de riquezas, podem se submeter à não-cumulatividade, sistemática concebida de tributos incidentes sobre aquela fonte tributável. Para entender a não-cumulatividade do PIS e da Cofins foi preciso pesquisar os tributos sobre vendas / consumo, tradicionais exemplos de tributos incidentes sobre a circulação de riqueza em cujo âmbito foi concebida a não-cumulatividade. Esse estudo consta do terceiro capítulo, no qual falamos também sobre o IPI e o ICMS, impostos brasileiros arrecadados por sistemática nãocumulativa. A fim de evitar os vícios da análise pela negativa, versamos inicialmente a cumulatividade tributária; afinal, para se entender "o que não é”, é preciso entender "o que é”. O preâmbulo do Capítulo 3 contempla premissas importantes, ao anunciar as diferenças entre a translação jurídica e a translação econômica dos tributos e ao explicar a equiparação terminológica entre tributos sobre vendas e tributos sobre consumo. É também neste capítulo que apresentamos nossa conclusão de que a norma que veicula a não-cumulatividade tributária contém características tanto de princípio como de regra. No quarto capítulo, analisamos as diferenças entre a não-cumulatividade do PIS e da Cofins e a não-cumulatividade do IPI e do ICMS; a ausência de traslado do encargo jurídico daquelas contribuições; a inexistência de um significado único de não-cumulatividade na CF/88 e os princípios a ela relacionados; a inserção da não-cumulatividade das referidas contribuições no texto constitucional; a inobservância, pela legislação ordinária, dos fatores de discrímen indicados pela CF/88 para diferenciação dos regimes cumulativo e não-cumulativo do PIS e da Cofins - os setores de atividade econômica; o método adotado para o creditamento do PIS e da Cofins, híbrido dos diversos métodos de cálculo dos tributos sobre o valor agregado; as características dos insumos que geram direito ao creditamento daquelas contribuições; e os efeitos da isenção e da alíquota zero para o PIS e a Cofins não-cumulativos. O capítulo 5 apresenta sinteticamente nossas conclusões.

PalaVRas-Chave: PIS; Cofins; não-cumulatividade; receita; vendas. 


\begin{abstract}
The present dissertation has 5 chapters. In the first chapter, we refer to the sources of taxation and to the economic criteria used by the Brazilian Federal Codification of Tax Law ("CTN") to classify Brazilian taxes. Having analyzed the economic concept of circulation, we were able to identify, in the group of taxes on the economic output and economic flow, a wide range of facts related to the economic flow of wealthiness, which is a main source of taxation. The second chapter refers to the source of taxation upon which non-cumulative PIS and Cofins. Such taxes have been specifically created to raise funds for social security activities and are collected through a special kind of value added method that is alleged not to promote a cascade effect on taxation. Since Brazilian Fundamental Law (“CF/88”) has pointed out the economic facts upon which the Federal Union is allowed to create taxes related to social security purposes, we believe it is possible to classify non-cumulative PIS and Cofins according to the economic classification of taxes presented by the "CTN". Having studied the economic fact upon which non-cumulative PIS and Cofins incur (i. e, all kinds of receipts earned by an economic enterprise) we concluded that those special taxes fall upon the economic output and economic flow, in other words, upon the economic flow of wealthiness. Because of that, we believe it is possible to collect those taxes using a value added method of taxation, for this kind of taxation has been designed to collect taxes upon that specific source of taxation. Because value added taxation was first thought to collect taxes upon the economic flow of wealthiness, it was deemed necessary to focus the researches on sales taxes, the most traditional taxes that fall upon that source of taxation. The results of that research are part of chapter 3, in which we also refer to IPI and ICMS, the Brazilian "value added" taxes. In order to avoid the imperfections that could arise from a reasoning based on a negative proposition, before broaching the non-cumulative methods of taxation, we have first broached the cumulative effects of a sales taxation. The preamble of chapter 3 contemplates important assumptions: it indicates the differences between the economic and legal shifting of taxation and the equalization of the terminology "sales taxes" and "consumption taxes". In this chapter we also present our conclusion according to which the laws providing for the non-cumulative effect of taxation in Brazil can be analyzed either as a principle or as a rule. In chapter 4 we discourse about: the differences between the non-cumulative effect of PIS and Cofins and the noncumulative effect of IPI and ICMS; the inexistence of a legal shifting of non-cumulative PIS and Cofins; the inexistence of a single meaning of non-cumulative taxations in "CF/88" and the principles related to this kind of collection system; the reasons why the non-cumulative way of collecting PIS and Cofins was inserted in "CF/88"; how lawmakers disrespected the only criteria that they could use to distinguish what kind of economic enterprises and the receipts would be subject to the non-cumulative collection device for PIS and Cofins; the special method designed to allegedly collect PIS and Cofins only on the value added in each transaction, that mixes criteria of existing methods of value added collection; what kind of inputs shall be deduced in order to find the value added in each transaction; and the effects of exemptions. Chapter 5 presents our conclusions, in a concise way.
\end{abstract}

KEYWORDS: PIS; Cofins; non-cumulativity; receipts; sales. 